\title{
Adherence to Appropriate Instructional Practice Guidelines in American College and University Physical Activity Programs
}

Drue T. Stapleton

West Virginia University

Follow this and additional works at: https://researchrepository.wvu.edu/etd

\section{Recommended Citation}

Stapleton, Drue T., "Adherence to Appropriate Instructional Practice Guidelines in American College and University Physical Activity Programs" (2012). Graduate Theses, Dissertations, and Problem Reports.

4924.

https://researchrepository.wvu.edu/etd/4924

This Dissertation is protected by copyright and/or related rights. It has been brought to you by the The Research Repository @ WVU with permission from the rights-holder(s). You are free to use this Dissertation in any way that is permitted by the copyright and related rights legislation that applies to your use. For other uses you must obtain permission from the rights-holder(s) directly, unless additional rights are indicated by a Creative Commons license in the record and/ or on the work itself. This Dissertation has been accepted for inclusion in WVU Graduate Theses, Dissertations, and Problem Reports collection by an authorized administrator of The Research Repository @ WVU.

For more information, please contact researchrepository@mail.wvu.edu. 
Adherence to Appropriate Instructional Practice Guidelines in American College and University Physical Activity Programs

\author{
Drue T. Stapleton
}

Dissertation Submitted to the

College of Physical Activity and Sport Sciences

at West Virginia University

in partial fulfillment of the requirements

for the degree of

Doctor of Philosophy in

Kinesiology

Sean M. Bulger, Ed.D., Chair

Leslie Cottrell, Ph.D.

Andrew Hawkins, Ph.D.

Vincent G. Stilger, HSD, ATC

Richard T. Walls, Ph.D.

Department of Coaching and Teaching Studies

Morgantown, West Virginia

2012

Keywords: higher education physical activity program; college student; program evaluation

Copyright 2012 Drue T. Stapleton 


\section{Abstract \\ Adherence to Appropriate Instructional Practice Guidelines in American College and University Physical Activity Programs}

\section{Drue T. Stapleton}

Background/Purpose: Higher education physical activity programs (HEPAP) in physical education have existed in American college and universities for over 100 years. Initially used to teach physical education and promote physical activity to prepare students for potential wartime conflicts, they have evolved in response to changes in societal and educational purposes and needs. In 2008, NASPE published its updated Guidelines for Appropriate Instructional Practice in Higher Education Physical Activity Programs. The guidelines educate professionals about effective physical education for post-secondary students, but knowledge of their use is limited. The purpose of the study was to examine familiarity and adherence to these guidelines.

Method: Researchers developed and piloted an electronic survey to assess familiarity and adherence with the guidelines related to curriculum and instruction. The survey included 61items arranged in pre-existing content areas: Administration/Support, Assessment, Instruction Strategies, Professionalism, Learning Environment, and Curriculum. The survey was distributed to HEPAP representatives at U.S. colleges/universities offering a physical education teaching degree $(\mathrm{N}=596)$.

Analysis/Results: In total, 159 participants (26.7\%) initiated the survey with 90 (15.1\%) providing usable responses and the remaining $69(11.5 \%)$ excluded due to no HEPAP or incomplete data. The data were transformed into categorical levels indicating a high degree of overall familiarity (96.7\% full or partially familiar) and adherence (99\% full or partially adherent). Full adherence to the content areas ranged from 91.8\% (Administration/Support) to 0\% (Instruction Strategies). Significant associations between Administration/Support and location (AAHPERD district) $\left(\chi^{2}(10, \mathrm{n}=71)=23.98, \mathrm{p}=.008\right)$ and Assessment and location $\left(\chi^{2}(10, \mathrm{n}=90)=19.39, \mathrm{p}=.036\right)$ were seen.

Conclusions: College physical education programs have been called on to provide students opportunities to develop an appreciation for, and increased participation in lifetime activity. While overall adherence to relevant professional guidelines appears high among HEPAPs, there is room for improvement in selected areas including Instruction Strategies and Assessment.

Key Words: program evaluation, college physical activity program, college student 


\section{Dedication}

This work is dedicated to my parents, Michael and Mary Stapleton, who in their own way, taught me the importance of education and the value of hard work and persistence. Their love and support have helped shape me into the person I am today and will continue wherever life takes me.

This work is also dedicated to my grandparents, the late Joseph and Palma Giuffre, whose faith was stronger than anyone I know. 


\section{Acknowledgements}

I would like to express my sincere appreciation to all those individuals who have assisted me throughout this process. Without their support and guidance, I may not have gotten to where I am today as a person and as a professional.

I wish to thank my committee: Dr. Andrew Hawkins, Dr. Richard Walls, Dr. Lesley Cottrell, Dr. Vince Stilger, and my chair, Dr. Sean Bulger. Dr. Hawkins, thank you for sharing your experience and insight from start to finish throughout this journey. Dr. Walls, thank you for helping me develop my technical writing skills and navigate through the methods and results section. Dr. Cottrell, thank you for being a sounding board, for your guidance throughout my doctoral training, and for your insightful comments and suggestions. Dr. Stilger, thank you for providing me the opportunity to advance my career and education as your Graduate Assistant. I have learned more by working with you than you realize. Finally, to my chair, Dr. Bulger, who has made countless contributions toward my success in my career:thank you for your guidance, mentoring, and especially your patience, over the five years I have spent bugging you.

Special acknowledgements go to Dr. Sam Zizzi, Dr. Damien Clement, Dr. Keith Zullig, and Dr. Stephanie Frisbee for their sharing of ideas, consultation, and general support. Anytime I had questions, I could count on you to lend an ear, help troubleshoot, or simply let me vent. Thank you collectively, and individually, for being available to consult on issues I have faced as a student and researcher.

Special thanks also to Robin McKinney, Carol Straight, and Theresa Scafella for their tireless, often unrecognized, work in the College of Physical Activity and Sport Sciences. Thank you ladies, for all your support and assistance.

I would also like to acknowledge all the students I have had the opportunity to teach, work with, and watch develop as professionals. Their questions, comments, and challenges have been a significant influence on me as a student, teacher, and researcher.

Last, and certainly not least, I wish to thank my wife, Phoebe, and son, Noah. Words are not strong enough to express my sincere gratitude for the countless discussions, questions, and critiques you have provided along the way. Your constant, unwavering love and support have been critical to completing this process, and helping me grow as a professional, husband, and father. 


\section{Table of Contents}

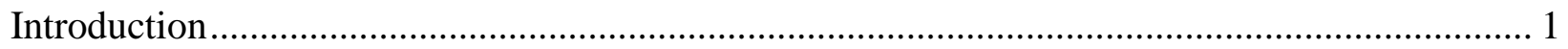

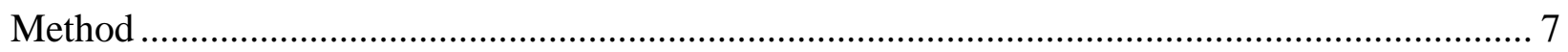

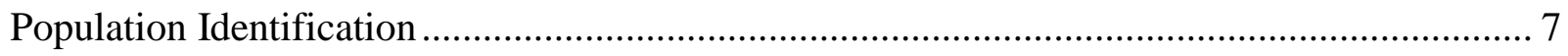

Research Design .......................................................................................................... 7

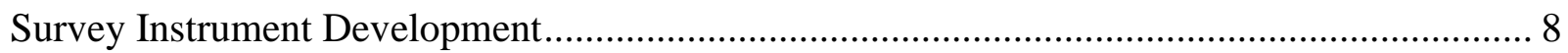

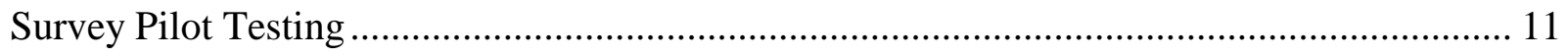

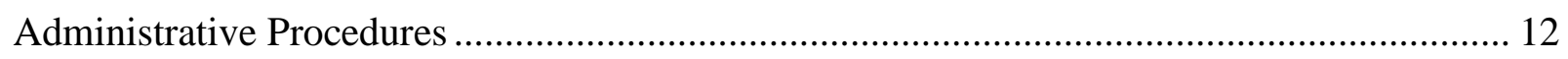

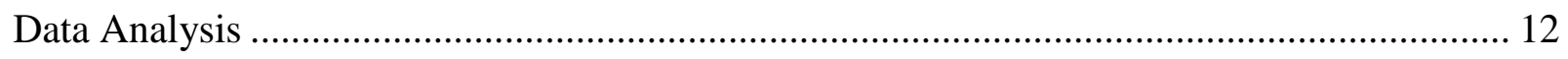

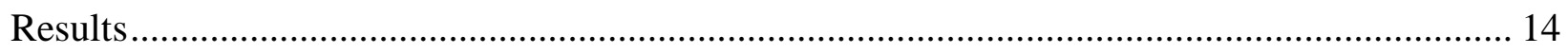

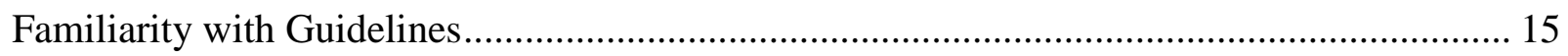

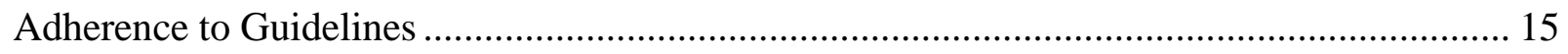

Association of Overall Adherence and Familiarity ……………………............................... 16

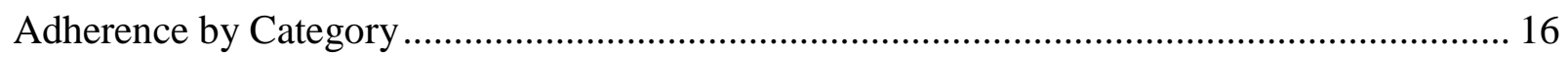

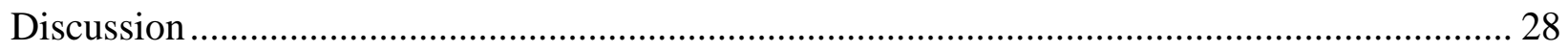

Higher Adherence: Administration and Support and Professionalism .................................... 28

Partial Adherence: Learning Environment and Curriculum. …………………................... 30

Lower Adherence: Instruction Strategies and Assessment .................................................... 32

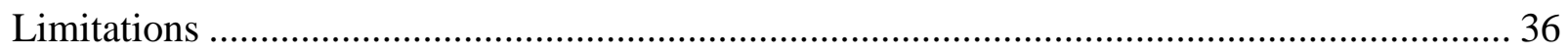

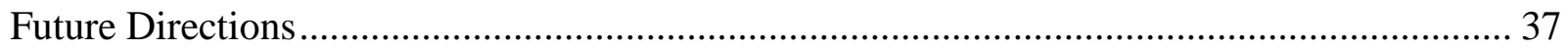


Conclusion

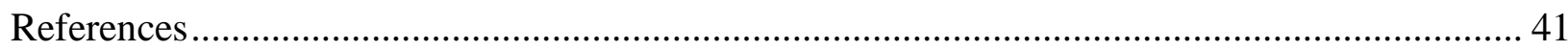

Appendix A: Extended Literature Review ....................................................................... 49

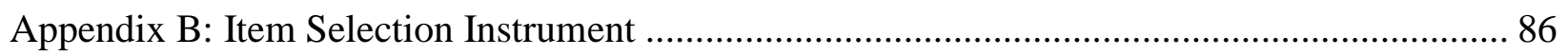

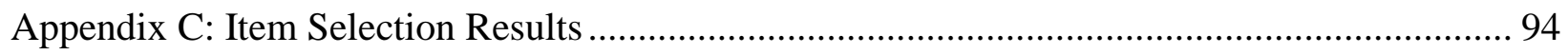

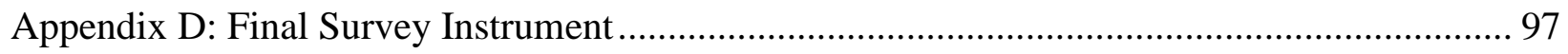

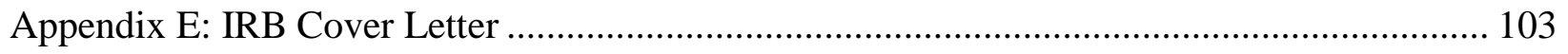

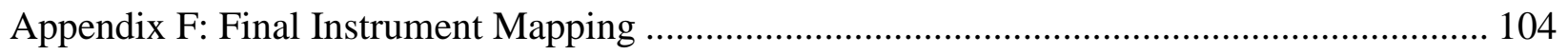

Appendix G: Familiarity and Institutional Variables...................................................... 106

Appendix H: Overall Adherence and Institutional Variables ........................................... 120

Appendix I: Familiarity and Overall Adherence ......................................................... 134

Appendix J: Category Adherence and Institutional Variables........................................... 136

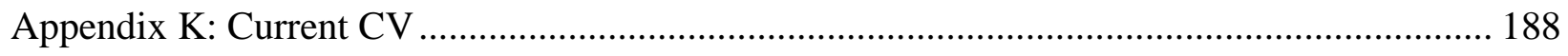




\section{Running Head: ADHERENCE TO INSTRUCTIONAL PRACTICE GUIDELINES 1}

\section{Introduction}

The physiological and psychological benefits associated with a physically active lifestyle have been well documented in the literature over the past two decades with respect to reduced risk for premature death, cardiovascular disease, diabetes, colon cancer, obesity, orthopedic ailment, depression, and anxiety (Centers for Disease Control and Prevention \& American College of Sports Medicine, 1995; U.S. Department of Health and Human Services, 1996, 2001). Despite the well-established benefits associated with a physically activity lifestyle, only 25 percent of U.S. adults engage in regular moderate physical activity (PA) and 29 percent report no leisure time PA (Centers for Disease Control and Prevention, 2001). The PA levels observed among college-aged individuals also appear problematic, with 57 percent of males and 61 percent of females reporting no moderate or vigorous PA on at least three of seven days per week (American College Health Association, 2001). More recent data show 80.5 percent of college students do not meet American College of Sports Medicine and American Heart Association recommendations for moderate exercise and 73.7 percent do not meet recommendations for vigorous exercise per week (American College Health Association, 2011).

The documented decline in PA that occurs as age and year in school increases, which has been shown to worsen in college-aged individuals (Caspersen, Pereira, \& Curran, 2000), is particularly disconcerting when one considers the persistence of sedentary behaviors through childhood and adolescence into adulthood. Leslie, Fotheringham, Owen, and Bauman (2001) examined PA participation rates of young Australian adults and found a 15 percent decline in vigorous activity and 10 percent decline in moderate PA from 18-19 year old adults to 25-29 year old adults. Sparling and Snow (2002), in a survey of college graduates, found that 85 percent of respondents who exercised regularly as a college senior remained active at the same 
level or higher six years later. Conversely, 81 percent of those respondents who were not active as college seniors reported their PA level at or less than what it was during their senior year.

A number of personal, psychological, social, and environmental factors have been shown to influence PA levels and provide insight into the previously described trends among college students and other segments of the population (Buckworth \& Dishman, 2002; Trost, Owen, Bauman, Sallis, \& Brown, 2002). For example, social ecological models of health "focus on individual influences as well as on social and environmental factors that may facilitate or inhibit individual behaviors" (Spence \& Lee, 2003, p. 8) and incorporate multiple levels of interaction regarding behaviors and behavior settings (McLeroy, Bibeau, Steckler, \& Glanz, 1988; Stokols, 1992,1996). McLeroy et al. (1988) described five levels of influence: (a) intrapersonal, (b) interpersonal, (c) institutional, (d) community factors, and (e) public policy. The models recognize that behavior is influenced by both personal characteristics and environmental variables, suggesting that changes made at one level may impact all other levels (Spence \& Lee, 2003). Social ecological models have been recommended for studying PA as a public health issue due to the relative complexity of the challenge (Sallis et al., 2006). The emphasis on "cross-level analyses of health problems" and "incorporating two or more analytic levels" supports the use of social ecological theory to examine both individual and "aggregate manifestations of health problems" (Stokols, 1996, p. 287).

Social ecological models can also be used to frame the determinants of PA behavior. Buckworth and Dishman (2002) described six categories of determinants: (a) demographic and biological factors, (b) psychological factors, (c) behavioral attributes and skills, (d) social and cultural factors, (e) physical environment factors, and (f) PA characteristics. The determinants most relevant to college students are: self-efficacy, perceived barriers, and social support (Nahas, 
Goldfine, \& Collins, 2003). Self-efficacy has been used to predict PA levels in children, adolescents, and adults with college students being more likely to participate in the types of activities they feel most competent (Hildebrand \& Johnson, 2001). Perceived barriers to PA have been shown to exert a strong influence on the individual's behavior (Sallis \& Owen, 1999), determining how active he or she becomes. Potential barriers include time, social support, accessibility, scheduling, cost, aversion to activity, and competing demands (Calfas, Sallis, Lovato, \& Campbell, 1994; Nahas et al., 2003; Sechrist, Walker, \& Pender, 1987). Social support, in the form of exercising together, talking, or encouragement from friends, family, or staff has been shown to positively influence activity levels (Nahas et al., 2003; Sallis \& Owen, 1999). The barriers most commonly cited by college students include inconvenience (schedules and facilities), aversion, and competing demands (Calfas et al., 1994).

Despite the sedentary lifestyle that defines college living for many students and the numerous barriers that exist on campus, institutions of higher education are thought to be well positioned to provide an environment that is conducive to establishing positive health-related behaviors including regular PA (Sparling, 2003). The interaction of environmental and social influences available on most campuses emphasizes the potential contributions colleges and universities can make in facilitating the development of physically active lifestyles. In addition to the "built environment" (i.e., sidewalks and cross-walks, recreation facilities and green spaces, bike lanes and racks, facilities and equipment), most colleges and universities also provide students access to a wide range of recreational and instructional opportunities including formal physical education courses.

From a social ecological perspective, higher education physical activity programs (HEPAP), have the potential to positively influence college students of all backgrounds and 
interests. Institutional policies governing the administration of HEPAPs, university degree requirements, curricular aspects, and personnel decisions can also influence the environment on campuses. Sallis and McKenzie (1991) contended college physical educators may have "the best opportunity to prepare students to maintain patterns of regular physical activity" (p. 134). Hensley (2000) supported this assertion, highlighting the unique ability of HEPAPs to influence knowledge, attitudes, and behavioral skills of college students related to developing and maintaining a physically active lifestyle.

Physical education programs in college and universities have been in existence for over 100 years. Initially designed to provide students with a break from "the rigor of academics," they have evolved over the past 60 years in response to changing societal demands and student needs. Most of the literature investigating HEPAPs has focused on "periodic monitoring of status and practices" of these programs (Trimble \& Hensley, 1990, p. 65). The majority of these surveys have focused on a range of issues including availability of programs, requirements for graduation, curricular offerings, budgeting, personnel, credit hour value, and grading and assessment practices (Hensley, 2000; Hunsicker, 1954; Lumpkin \& Avery, 1986; Miller, Dowell, \& Pender, 1989; Oxendine, 1961, 1969, 1972, 1985; Oxendine \& Roberts, 1978; Trimble \& Hensley, 1984, 1990). More recent investigations have examined the trend of concepts based health and wellness (CBFW) courses (Hodges-Kulinna, Warfield, Jonaitis, Dean, \& Corbin, 2009), while others have focused on the impact of these course offerings on college students (Adams \& Brynteson, 1995; Brynetson \& Adams, 1993; Slava, Laurie, \& Corbin, 1984). In its entirety, this research indicates that HEPAPs have changed significantly since their inception in the late 1800's. Despite an overall decrease in the number of college and universities requiring physical education for graduation and a decrease in the actual number of programs, it appears 
HEPAPs remain firmly established on college and university campuses. The mere presence of a HEPAP, however, does not necessarily indicate the level of program quality or effectiveness.

The Task Force on Community Preventive Services (Kahn et al., 2002) concluded there was insufficient evidence for college based physical education programs as PA intervention venues. The Task Force pointed out that the lack of evidence should not be interpreted as college physical education programs are ineffective, but rather, that additional investigations are necessary to provide evidence of effectiveness. The potential of HEPAPs to be an optimal venue for PA interventions due to their ability to influence large numbers of individuals has not yet been realized. In order for HEPAPs to remain viable, administrators must be able to demonstrate their value to students, alumni, and institutional leaders.

Calls for additional research focused on HEPAPs (Housner, 1993), have gone largely unheard, with the majority of the related research focused on changes in trends and status, with little attention given to the evaluation of program quality or effectiveness. Given the lack of attention to evaluation of program quality, an appropriate starting point may be the utilization of guidelines from professional organizations pertaining to HEPAPs. Investigations to determine the optimal program variables, such as faculty roles, institutional demographics, and program and course format, may be the first step in maximizing the effectiveness of PA interventions delivered using HEPAPs.

The National Association for Sport and Physical Education (NASPE) Appropriate Instructional Practice Guidelines for Higher Education Physical Activity Programs are intended to "educate professionals about effective programming and teaching within a higher education curriculum" (NASPE, 2008, p. 3). The guidelines provide students, faculty, administrators, and policy makers with a template for "program administration," a tool to assess the "quality of 
instruction," and a framework to develop an effective program (p.3). Topic areas such as administration and support, assessment, instructional strategies, professional development, learning environments, staffing, and curricular evaluation are presented as a series of statements. The guidelines "represent expert consensus about appropriate and inappropriate practices observed in colleges/university instructional physical activity programs" (NASPE, 2008, p. 3), with the overall goal of ensuring that HEPAPs facilitate the development of physically educated persons.

The promotion of lifelong participation and an appreciation of PA is one of the commonly stated outcomes of HEPAPs (Hensley, 2000). However, based on current literature highlighting college student PA levels, HEPAPs may not be sufficiently accomplishing this desirable outcome. The disconnect between expected and actual outcomes leads to questions of the effectiveness of HEPAPs. The need for constant assessment in light of changing societal influences and student needs has led to calls for evaluation of college physical education programs (Evaul \& Hilsendanger, 1993; Leslie, Sparling \& Owen, 2001; Lumpkin \& Avery, 1986; Sparling, 2003). The NASPE guidelines for HEPAPs provide a social ecological framework to evaluate the individual, intrapersonal, environmental, and policy influences of HEPAPs in order to promote college student participation in lifetime PA. Adherence to the NASPE guidelines may provide valuable information regarding the quality of HEPAPs. However, to date, no investigations have been conducted to examine the extent to which these guidelines have been adhered to. Therefore, the purpose of this study was to examine the level of familiarity with and the level of adherence to the NASPE Guidelines for appropriate instructional practices in HEPAPs. 


\section{Method}

A lack of current research examining adherence to appropriate professional guidelines and the potential implications for HEPAP curriculum and instructional environment provide the primary justification for this study. The following sections include an overview of the methods proposed for population identification, research design, instrumentation, procedures and protocols, data collection, and data analysis.

\section{Population Identification}

Following IRB approval, the researcher recruited participants from an existent database of key department contacts at colleges and universities offering an undergraduate degree in physical education teacher education (PETE). The database was constructed for the purpose of a previous study and the process included Internet searches to identify all four year institutions of higher education that offer an undergraduate degree in PETE $(\mathrm{N}=644)$. It was presumed that college and universities offering a PETE degree would model appropriate professional practices in the preparation of future physical education teachers, and as a result, appropriate professional practices would carry over to their PA programs. Due to the small size, the entire population of key department contacts was surveyed excluding those randomly selected to participate in the pilot study.

\section{Research Design}

A non-experimental, cross-sectional descriptive survey research design was used. Crosssectional surveys are effective for identifying behavior of a population at a given time (Gay, Mills, \& Airasian, 2009). Most recently within this line of research, Hensley (2000) and Hodges Kulinna et al. (2009) distributed surveys to physical education department chairpersons to assess status and trends within college and university basic instruction programs. Additional support 
for the use of a survey research design to measure adherence to professional guidelines is found out-of-field in McInnis, Hayakawa, and Balady (1997) and McInnis et al. (2001) who used mailbased surveys to assess adherence to cardiovascular emergency preparedness, and Kahanov, Furst, Johnson, and Roberts (2003) who assessed adherence to national drug-dispensation laws. Survey research, in general, has inherent advantages and disadvantages. The advantages include reduced cost, maintenance of anonymity and confidentiality, and ease of access to respondents (Gay et al., 2009). The disadvantages of survey research include an inability to follow up or explain items to respondents, the potential for multiple responses from a single participant, and the potential for low response rate (Gay et al., 2009). A target response rate of 17\% (HodgesKulinna et al., 2009) was established for this study. The use of an Internet based survey delivery and management application, combined with rigorous development of the population database, survey instrument, and follow up procedures, addressed the other potential concerns.

\section{Survey Instrument Development}

The survey instrument was developed for the specific purpose of this study based on the Appropriate Instructional Practice Guidelines for Higher Education Physical Activity Programs (NASPE, 2008). In the original format the guidelines are grouped in the following categories:

(a) Administration and Support, (b) Assessment, (c) Instruction Strategies, (d) Professionalism,

(e) Learning Environment, (f) Program Staffing, and (g) Curriculum. Prior to their inclusion in the survey instrument for this study, each individual guideline was critiqued by the researcher and revised, re-written, or divided as needed into multiple statements to improve clarity and avoid the use of double-barreled statements. The resultant 107 prospective survey items were reviewed by another researcher for clarity and ease of understanding. 
Given the rather extensive list of prospective survey items and the current research focus on curriculum and instructional environment, a panel of two reviewers with expertise in the area of HEPAP was purposefully selected to evaluate each survey item for content validity (reviewers identified below). For the purpose of this study, "Curriculum and Instructional Environment" (C\&I) was operationally defined as those guidelines which have a direct influence on student behaviors, student outcomes, student knowledge, student abilities, and/or student skill development. Items may include, but are not limited to guidelines related to areas such as: effective teaching, lesson structure, practice opportunities, maximizing PA, instructional strategies, instructor behaviors, and so forth. "Administration and Institutional Support” (A\&IS) was operationally defined as those guidelines which are departmental, program, or institutional administrative functions and/or those statements which do not have a direct influence on student behaviors, outcomes, knowledge, abilities, and/or skill development. Items may include, but are not limited to guidelines related to areas such as: program position, marketing, promotion, staffing, professional development, program evaluation, assessment, policy and procedures, and so forth. Reviewers were provided with a third category of "unclassified" for those items determined not to fit one of the previously provided definitions (Hinkin, 1998). The definitions identified reflect revisions made throughout the survey instrument development process.

The panelists were asked to sort 107 items into the corresponding categories using the definitions provided (Appendix B). Those items which both reviewers categorized in the C\&I category were selected for inclusion in the final survey. Content validity was established when both reviewers sorted a statement as belonging to the C\&I category. An overall interobserver agreement (IOA), calculated using the point-by-point agreement ratio, of greater than or equal to 80 percent (Hinkin, 1998; Kazdin, 2011) was used. Three rounds of categorization were 
completed prior to achieving the target level of agreement (Drs. Lynn Housner and Valerie Wayda, round one; Drs. Emily Jones and Robert Wiegand, round two; Drs. Kacey DiGiacinto and Wes Meeteer, round 3). After each round, the investigator met with the reviewers to better understand the areas of disagreement. Following these meetings, the operational definitions were revised to include comments and/or suggestions from the reviewers. Upon revising the operational definitions, two new reviewers were solicited to sort the items (Appendix C). The final round of selection resulted in the reviewers agreeing that 61 of the statements were related to $\mathrm{C} \& \mathrm{I}$ (IOA of 88 percent). The reviewers were not asked to provide any additional statements or comments for inclusion as the intended purpose of the research study was to evaluate adherence to the guidelines as they are written.

The resulting 61 items were organized into a survey format that asked participants to rate their program's level of adherence to each guideline for best practice using a 5-point Likert scale, anchored at 5 (Fully Adhered To) and 1 (Not At All Adhered To) (Appendix D). Participants selected one score, indicating the level of adherence of their respective institution, to that particular statement. Participants were given an option of not applicable for each item. Familiarity with the guidelines was assessed using a single question in which participants were asked to rate their level of familiarity using a three point Likert scale, with 3 indicating full awareness, 2 indicating partial awareness, and 1 indicating no awareness at all. Participants were also asked to identify the size of their institution, the affiliation (public versus private), the number of full-time faculty teaching in the HEPAP, the number of part-time faculty teaching in the HEPAP, and the number of graduate teaching assistants teaching in the HEPAP. Participants were also asked to identify if physical education is a requirement for graduation at their respective institution. Each of the sixty-one items included was then linked back to the 
corresponding statement from the guidelines. The corresponding guideline was included at the end of each statement as to facilitate the connection between the original guidelines and the instrument developed for the purpose of this study. The final sixty-one item survey was distributed to an additional panel of survey design experts for pre-testing and review of grammar, clarity of instructions, and other general administrative procedures (Kahanov et al., 2003; McInnis et al., 1997). Reviewers were asked to make comments related to those areas. Any comments, concerns, or issues were used to revise the instrument, procedures, or instructions prior to pilot testing.

\section{Survey Pilot Testing}

The pilot study employed an electronic survey format to help control administrative costs, minimize data entry errors, and expedite data collection and analysis. Survey Monkey ${ }^{\mathrm{TM}}$ (Menlo Park, CA) was used to manage survey administration and collection of participant responses. Survey Monkey ${ }^{\mathrm{TM}}$ is a publically accessible Internet-based software program that can be used to develop, deliver, and manage electronic survey projects. Participant responses were recorded, stored, and provided for analysis as Microsoft Excel spreadsheet files or Statistical Package for the Social Sciences ${ }^{\mathrm{TM}}$ (SPSS) data files. Response frequencies and percentages were calculated automatically. A hyperlink unique to the survey was included in the informational "cover sheet" email sent to all participants (Appendix E). The electronic survey was then distributed to a random sample of approximately 40 participants (Johanson \& Brooks, 2010) from the previously described database (initial request sent March 9, 2012).

Approximately two weeks after the initial email contact was made (March 20, 2012), a reminder email was sent to participants asking for responses. The pilot test was closed three weeks following the initial email contact due to time constraints and the overall goal of the pilot test. 
The purpose of the pilot testing process was to check the functionality of the electronic survey, procedures for survey administration, and systems for data collection, management, and analysis. Data collected during this stage were not included in the final analyses.

\section{Administrative Procedures}

Following pilot testing, the final survey was distributed electronically (April 3, 2012) to all remaining participants using the PETE database previously described $(\mathrm{N}=604)$. Participants received a general informational/recruitment/instructional email (Appendix E) highlighting the purpose of the research, confidentiality procedures, instructions for accessing and completing the survey as well as the hyperlink to the survey. Participants identified their consent to participate via answering a single question prior to completing the electronic instrument. If the department representative identified in the database was not the most qualified individual to respond to the survey, he or she was asked to forward the information/recruitment/instructional email to the appropriate individual for completion.

Fourteen days following the initial email (April 17, 2012), a second email was sent thanking participants who had completed the survey and reminding those who had not yet done so of the importance of their participation. The same general and procedural information, instructions, and hyperlink were included. Two weeks following the second email (May 2, 2012), a third email was sent to all participants. Again, those having completed the survey were thanked and the importance of participation was highlighted for those who had not yet completed the survey.

\section{Data Analysis}

The data from the completed surveys were downloaded from Survey Monkey ${ }^{\mathrm{TM}}$ and converted for use in SPSS ${ }^{\mathrm{TM}}$ (version 19) for analysis. Descriptive statistics, including frequency of responses (and percentages) were calculated for all items using SPSS. To address the research 
question related to the identification of familiarity with the NASPE Guidelines, frequencies for each level of familiarity (fully aware, somewhat aware, and not at all aware), median, and mode were determined. To address the research question related to identifying the level of adherence to the NASPE guidelines the overall adherence level was calculated for each completed survey. Likert-scale questions were analyzed by establishing a categorical level of adherence. Items rated a 5 or 4 on the Likert-scale were considered fully adhered to, 3 partially adhered to, and 2 or 1 as not at all adhered to. Linking each of the sixty-one statements included in the final survey instrument to the corresponding guideline allowed for the statements to be grouped using the original category titles (Appendix F). Utilizing the six categories represented in the final survey, an adherence level for each category was determined. The Likert-type data were transformed and re-coded into categories of Fully Adhered To, Partially Adhered, and Not at All Adhered to. A category was considered "Fully Adhered To" if adherence to $80 \%$ of the items in the particular category were rated as Fully Adhered To. Lack of adherence ("not at all adhered to") was defined as adherence to $80 \%$ of the items in the particular category being rated not at all adhered to. Partial Adherence was defined as not being fully adherent nor lacking adherence. Frequency distributions, including percentages, of adherence to individual guidelines (Table 2) and to the categories were constructed.

As the purpose of this investigation was to describe the level of familiarity with and adherence to the NASPE guidelines, $\chi^{2}$ analyses were conducted. Comparisons were made based on (1.) overall familiarity and institutional variables, (2.) familiarity and overall adherence, (3.) overall adherence and institutional variables, and (4.) category adherence and institutional variables. 


\section{Results}

Participants were HEPAP representatives as identified from a database of four year institutions of higher education within the United States offering an undergraduate program in PETE (N=596). Institutional demographics are displayed in Table 1. One hundred fifty nine participants out of 596 initiated the survey (26.7\%) and 90 provided usable responses (15.1\%). Of the remaining 69 participants, 20 indicated that their college/university had no HEPAP and 49 were not included in the analysis due to large quantities of missing survey data or large sections of the survey being skipped. One hundred thirty $(82 \%)$ of responding institutions that initiated the survey, offered a HEPAP, with 77 (48.4\%) requiring physical education for graduation. These numbers are slightly lower than previous reports (Hensley, 2000). One-hundred twentysix $(79.2 \%)$ HEPAPs were housed in the same department as the PETE program, with exercise science, health science, and recreation as the most commonly reported alternate if not in the same department (data not shown).

Of those respondents who completed the survey, $53(60.9 \%)$ reported having a physical education requirement for graduation. The institutions responding represent a geographically diverse set, with 38 (42.7\%) from the Southern AAHPERD District, 21 (23.6\%) Midwest, 14 (15.7\%) Central, 7 (7.9\%), Northwest, 5 (5.6\%) Southwest, and 4 (4.5\%) Eastern. Institutional size was collapsed to Small (enrollment between 500 and 2500 students), Medium (250110,000), and Large (> 10,000) due to small sample sizes within each category, resulting in relatively equal distribution within each revised size category (Small, n=38, 42.7\%; Medium, $\mathrm{n}=26,29.2 \%$; and Large, $\mathrm{n}=25,28.1 \%$ ). Institutional affiliation was also relatively equally distributed with $48(53.9 \%)$ public and $41(46.1 \%)$ private. 


\section{Familiarity with Guidelines}

The results for overall familiarity with the Guidelines can be seen in Figure 1. Fifty (55.6\%) participants reported being fully aware, 37 (41.1\%) reported being partially aware, and 3 (3.3\%) were totally unaware of the guidelines, indicating a moderate to high level of awareness overall. The results, when examined based on institutional variables (Appendix G) revealed a similarly high level of overall familiarity, independent of affiliation, student enrollment, location, and the presence of a physical education requirement for graduation. The $\chi^{2}$ analyses revealed no significant associations between familiarity with the NASPE Guidelines and any of the institutional variables. However a pattern of higher percentages of full or partial awareness to the guidelines was seen among institutions requiring physical education for graduation and among those with smaller enrollments.

\section{Adherence to Guidelines}

Frequency distributions for adherence to each individual guideline can be seen in Table 2 . Collectively, the majority of items were rated as being either fully or partially adhered to. Guideline 3.10.1B had the highest percentage of non-adherence $(\mathrm{n}=22,24 \%)$ and Guideline 1.3.1 had the highest percentage of full adherence $(n=73,92 \%)$. Overall adherence to the Guidelines is displayed in Figure 2. Fifty (53.8\%) of respondents indicated their institution was fully adherent to the guidelines; forty two (45.2\%) were partially adherent, and one (1.1\%) was completely non-adherent. Comparisons of overall adherence and institutional variables revealed similar patterns of high percentages of institutions partially or fully adhering to the Guidelines. Institutions with smaller enrollments had the highest percentages of partial $(n=17,18.9 \%)$ and full $(n=20,22.2 \%)$ adherence. As with familiarity, a pattern was observed among institutions 
that require physical education for graduation having higher partial $(n=24,26.7 \%)$ and full $(\mathrm{n}=30,33.3 \%)$ adherence compared to those institutions not requiring PE for graduation $(\mathrm{n}=17$, $18.9 \% ; n=18,20 \%)$; no such patterns were evident with respect to location or affiliation. There were no significant associations between overall adherence and the institutional variables though (Appendix H).

\section{Association of Overall Adherence and Familiarity}

There was a significant association $\left(\chi^{2}(4, \mathrm{n}=90)=11.16, \mathrm{p}=.025\right)$ between overall adherence and familiarity with the Guidelines (Figure 3 and Appendix I). This association confirmed the relationship between the high level of awareness and high levels of adherence seen in the data. It is reasonable to expect institutions reporting higher levels of awareness would also report higher levels of adherence. It is interesting to note that institutions that reported a lack of awareness of the Guidelines $(n=3)$ were at least partially adherent to them.

\section{Adherence by Category}

General adherence to the categories identified from the guidelines is displayed in Figure 4 and Appendix J. The percentage of institutions fully adhering to the categories are as follows: Administration and Support, 91.8\%; Assessment, 38.7\%; Instruction Strategies, 0\% (no institutions fully adhered to this category, $97.8 \%$ were in partial adherence); Professionalism, 76.7\%; Learning Environment, 68.9\%; and Curriculum, 67.4\%. Overall, a high percentage of institutions either partially or fully adhere to all categories. Higher percentages of institutions that require physical education for graduation fully adhere to the Administration and Support $(\mathrm{n}=$ 42, 59.2\%), Assessment ( $n=25,27.8 \%)$, Professionalism $(n=42,48.3 \%)$, Learning Environment $(n=40,46 \%)$, and Curriculum $(n=40,46.5 \%)$ categories than those institutions that do not require physical education, however, the percentages did not reach statistical significance. 
Public institutions have higher percentages of partial adherence to the Professionalism $(n=13,14.6 \%)$, Learning Environment $(n=19,21.3 \%)$, and Curriculum $(n=17,19.3 \%)$ categories than private institutions. There appears to be a pattern of decreasing frequencies of full adherence from smaller institutions to larger institutions, overall and across all categories. There was a significant association between adherence to the Administration and Support category and location $\left(\chi^{2}(10, \mathrm{n}=71)=23.98, \mathrm{p}=.008\right.$; Figure 5). This association may be related to the two (40\%) institutions in the Northwest AAHPERD district being in full adherence with the Administration and Support category, compared to other districts which reported $89 \%$ full adherence or higher. Institutions within the Northwest district also had a higher percentage of partial adherence $(n=2,66.7 \%)$ to the Administration and Support category compared to institutions from other districts.

There was also a significant association between adherence to the Assessment category and location $\left(\chi^{2}(10, n=90)=19.39, p=.036\right.$; Figure 6$)$. This association may be related to institutions within the Eastern AAHPERD district having the highest percentage of full adherence to the Assessment guidelines $(n=3,75 \%)$ compared to other districts, and institutions in the Northwest district having the lowest percentage $(n=1,14.3 \%)$. Additionally, there was a trend toward a significant association between adherence to Learning Environment guidelines and affiliation $\left(\chi^{2}(2, \mathrm{n}=90)=4.64, \mathrm{p}=.099\right.$; Figure 7$)$, but was not large enough to reach statistical significance. This trend may be related to the larger number of public institutions partially adhering to the guidelines $(n=19,38.8 \%)$ compared to private institutions $(n=8,20 \%)$. Collectively, these data indicate a high level of adherence to the NASPE guidelines through the percentages of institutions either fully or partially adhering. 
Table 1

Description of Respondents Based on Institutional Demographic Variables

\begin{tabular}{lcc}
\hline Institutional Demographic & & \\
& & \\
Presence of HEPAP* & Frequency & Percentage \\
\cline { 2 - 3 }$\quad$ Yes & 130 & 82 \\
$\quad$ No & 1 & 13 \\
$\quad$ Unsure & 1 \\
Graduation Requirement** & & \\
$\quad$ Yes & 53 & 60.9 \\
$\quad$ No & 34 & 39.1 \\
Affiliation** & & \\
$\quad$ Public & 48 & 53.9 \\
$\quad$ Private & 41 & 46.1 \\
Student Enrollment** & & \\
$\quad$ Small (500-2500) & 38 & 42.7 \\
$\quad$ Medium (2501 - 10,000) & 26 & 29.2 \\
$\quad$ Large (> 10,000) & 25 & 28.1 \\
AAHPERD District** & & \\
$\quad$ Eastern & 4 & 4.5 \\
Southern & 38 & 42.7 \\
$\quad$ Midwest & 21 & 23.6 \\
Central & 14 & 15.7 \\
Southwest & 5 & 5.6 \\
$\quad$ Northwest & 7 & 7.9
\end{tabular}

Note. * indicates data from all respondents. ** indicates data only from those respondents who completed the survey 


\section{Familiarity with NASPE Guidelines}

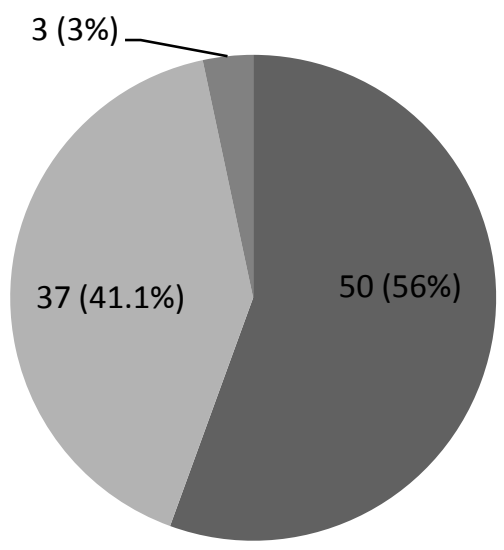

FULLY AWARE

SOMEWHAT AWARE

NOT AT ALL AWARE

Figure 1. Frequency Distribution of Respondents Familiarity with NASPE Guidelines

\section{Overall Adherence to NASPE Guidelines}

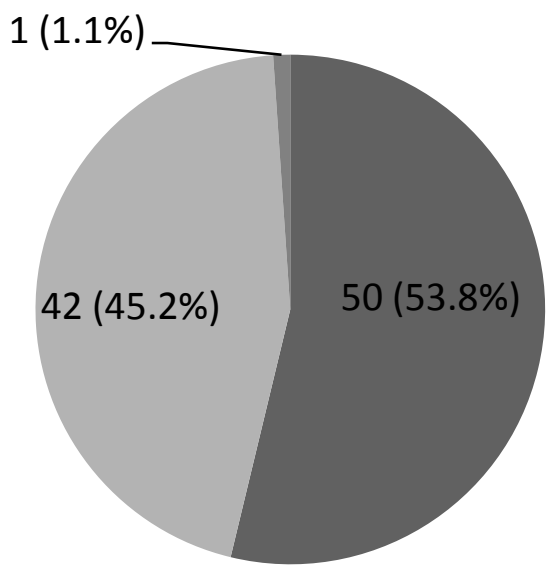

Figure 2. Frequency Distribution of Respondents Overall Adherence to NASPE Guidelines 
Table 2

Frequency Distribution for Adherence to Individual Items Organized by Category

\begin{tabular}{|c|c|c|c|c|c|}
\hline $\begin{array}{l}\text { Associated } \\
\text { Guideline }\end{array}$ & Item & $\mathrm{n}$ & $\begin{array}{c}\text { Full } \\
\text { Adherence }\end{array}$ & $\begin{array}{c}\text { Partial } \\
\text { Adherence }\end{array}$ & $\begin{array}{c}\text { No } \\
\text { Adherence }\end{array}$ \\
\hline \multicolumn{6}{|c|}{ Administration and Support } \\
\hline 1.3 .1 & $\begin{array}{l}\text { The program adheres to course policies consistent with all other credit- } \\
\text { bearing coursework within the institution, including those regarding } \\
\text { instructor and student responsibilities and expectations, administrative } \\
\text { roles, and standards of professionalism. }\end{array}$ & 73 & $67(92)$ & $3(4)$ & $3(4)$ \\
\hline \multicolumn{6}{|l|}{ Assessment } \\
\hline 2.1.1A & $\begin{array}{l}\text { The program uses assessments to inform and help students progress toward } \\
\text { intended outcomes. }\end{array}$ & 73 & $59(81)$ & $7(10)$ & $7(10)$ \\
\hline 2.1.1B & $\begin{array}{l}\text { Formative and summative assessments constitute an ongoing and integral } \\
\text { part of the learning process for all students }\end{array}$ & 73 & $52(71)$ & $13(18)$ & $8(11)$ \\
\hline 2.2.1 & $\begin{array}{l}\text { Instructors assess all domains (cognitive, affective, psychomotor and } \\
\text { health-related fitness) systematically }\end{array}$ & 73 & $43(59)$ & $17(23)$ & $13(18)$ \\
\hline 2.2 .2 & $\begin{array}{l}\text { The program conducts individual student evaluations though a variety of } \\
\text { assessment techniques }\end{array}$ & 83 & $59(71)$ & $17(20)$ & $7(8)$ \\
\hline 2.2 .3 & $\begin{array}{l}\text { Appropriate tests are used for students with disabling conditions. } \\
\text { Instructors are encouraged to use fitness assessments as part of the ongoing }\end{array}$ & 80 & $58(73)$ & $13(16)$ & $9(11)$ \\
\hline 2.3 .1 & $\begin{array}{l}\text { process of helping students understand, improve and maintain their physical } \\
\text { fitness and well-being }\end{array}$ & 83 & $61(73)$ & 15 (18) & $7(8)$ \\
\hline 2.4 .1 & $\begin{array}{l}\text { Instructors create testing situations that are private, non-threatening, } \\
\text { educational and encouraging }\end{array}$ & 81 & $56(69)$ & $18(22)$ & $7(9)$ \\
\hline 2.4 .2 & Instructors explain what the assessment is designed to measure. & 82 & $62(76)$ & $16(20)$ & $4(5)$ \\
\hline 2.4 .3 & $\begin{array}{l}\text { Instructors encourage students to avoid comparisons and use the results as a } \\
\text { catalyst for personal improvement }\end{array}$ & 89 & $68(76)$ & $18(20)$ & $3(3)$ \\
\hline 2.5 .1 & $\begin{array}{l}\text { Assessment results are shared privately with students, with the aim toward } \\
\text { developing personal goals and strategies for maintaining fitness and skill } \\
\text { parameters. }\end{array}$ & 88 & $68(77)$ & $13(15)$ & $7(8)$ \\
\hline
\end{tabular}


2.5.2 Instructors provide students with progress reports regularly using a variety of continuous, formative evaluations and assessments

2.6.1 Grades are based on thoughtfully identified criteria that are aligned with exit outcomes.

2.6.2 Students know the components of and/or criteria included in their grades. Program assessment is used to determine program effectiveness, to

2.7.1 communicate goals to the student body, faculty and administration, and to revise curricula.

Instruction Strategies

3.1.1 Instructors communicate clear outcomes for student learning and performance.

3.2.1 Instructors form pairs, groups and teams in a manner that facilitates learning and preserves dignity and self-respect for all students.

3.3.1A

3.3.1B

3.3.2

$3.4 .1 \mathrm{~A}$

3.4.1B

3.6.1B Class begins with an anticipatory set and physical warm-up that precedes the instructional focus and fitness activities.

Activities are designed based on a pre-evaluation, outcome of the course and student needs.

The instructor plans for skill and concept instruction

The instructor allows enough time for practice, skill development, content acquisition and feedback based on (appropriate) skill analysis. Instructors organize classes to maximize opportunities for all students to learn and be physically active.

Instructors use small sided games or mini-activities to allow students ample opportunity to participate.

Instructors use a variety of direct and indirect teaching styles depending on outcomes, lesson content, and students' varied learning styles.

Instructors emphasize critical thinking and problem solving tactics and strategies to help students apply concepts and skills to post-graduation experiences.

3.8 .1 Students practice skills and achieve success appropriate to their individual skill level. 
3.9.1 Students receive positive, constructive, and specific corrective feedback about performance.

3.10.1A Instructors include technology (e-mail, internet, video recording) to improve teaching effectiveness and class management.

3.10.1B Instructors include technology to quantify activity (pedometers, heart rate monitors, etc).

Professionalism

4.2.1A

Instructors demonstrate an understanding of basic motor skills.

Instructors provide accurate demonstrations for dominant and non-dominant

4.2.1B

4.3.1 performance through teacher or student modeling or via visual aid.

Instructors continually seek new information to stay current in the field.
89

$78(88)$

89

$57(64)$

90

$40(44)$

88

88

88

$73(83)$

$66(75)$

$59(67)$

$10(11)$

$17(19)$

$20(23)$

$28(31)$

$22(24)$

Learning Environment

Instructors systematically plan for, develop, and maintain a positive

5.1.1 learning environment that allows students to feel safe, supported and unafraid to make mistakes.

5.1.2 The environment is supportive of all students and promotes developing a positive self-concept

5.1.3 Fair and consistent classroom-management practices encourage student responsibility for learning.

5.2.1A Instructors promote exercise for its contribution to a healthy lifestyle.

$5.2 .1 B$ Students are encouraged to participate in physical activity and exercise outside the class setting for skill development, enjoyment, and good health.

5.3.1 Activities are carefully selected to ensure they match students' ability levels and are safe for all students regardless of ability level

5.3.2 Activities are carefully selected and modified to ensure a safe learning environment for students.

Instructors create an environment that is inclusive and supportive of all

5.4.1 students, regardless of race, ethnic origin, gender, sexual orientation, religion, or physical ability.

5.5.1A

All students have equal opportunities for participating in and during activity time and interaction with the instructor.
90

$71(79)$

$14(16)$

90

72 (80)

$15(17)$

$90 \quad 77(86 \%)$

9 (10)

4 (4)

90

90

$78(87)$

$8(9)$

4 (4)

4 (4)

$78(87)$

$8(9)$

8 (9)

90

65 (72)

$17(19)$

$5(6)$

89

70 (78)

15 (17)

4 (4)

88 
5.5.1B All students, regardless of developmental level and ability, are challenged at an appropriate level.

5.5.2 Instructors use gender neutral and respectful language

5.6.1 Instructors implement the special education process for students with disabling conditions, as provided through student services.

$5.6 .2 \mathrm{~A}$ Lessons/activities are adapted for students with varied fitness and/or skill levels.

5.6.2B Students are encouraged to participate at appropriate levels of activity for their own improvement.

5.6.3 Instructors provide appropriate experiences for students with acute medical limitations (i.e. student with broken arm can ride exercise bike).

5.7.1A Instructors help students recognize that adults engage in sport and exercise activities both to socialize and compete.

5.7.1B A deeper understanding of competition is fostered, one that encourages students to reflect on ideas such as rivalry, competence, and affiliation.

Curriculum

Instructors encourage students to extend experiences from in-class activity lessons to campus, community, and family activities that promote a physically active lifestyle.

Curriculum offerings provide opportunities for students to interpret and use assessment data to set personal goals, including developing a lifelong fitness plan.

7.8.1 The program establishes outcomes that reflect 4 domains (cognitive, affective, psychomotor, health-related fitness).

Program offerings include content that allows students to develop social

7.8.2 skills and responsible behavior that will lead them to become productive members of society.

Course content aims to provide opportunities for all students to experience

7.8.3 the satisfaction and joy that can result from participating regularly in physical activity.

7.8.4 Course content is delivered in a way that encourages students to recognize that physical activity is an important part of everyday living.

\begin{tabular}{|c|c|c|c|}
\hline 88 & $66(75)$ & 17 (19) & $5(6)$ \\
\hline 88 & $71(81)$ & $12(14)$ & $5(6)$ \\
\hline 86 & $64(74)$ & $17(20)$ & $5(6)$ \\
\hline 89 & $69(78)$ & $15(17)$ & $5(6)$ \\
\hline 87 & $78(90)$ & $9(10)$ & $O(0)$ \\
\hline 89 & $68(76)$ & $15(17)$ & $6(7)$ \\
\hline 89 & $75(84)$ & $9(10)$ & $5(6)$ \\
\hline 84 & $46(55)$ & $27(32)$ & $11(13)$ \\
\hline 89 & $68(76)$ & $16(18)$ & $5(6)$ \\
\hline 89 & $60(67)$ & $16(18)$ & $13(15)$ \\
\hline 87 & $59(68)$ & $17(20)$ & $11(13)$ \\
\hline 89 & $64(72)$ & $18(20)$ & $7(8)$ \\
\hline 89 & $71(80)$ & $13(15)$ & $5(6)$ \\
\hline 88 & $71(81)$ & $13(15)$ & $4(5)$ \\
\hline
\end{tabular}


ADHERENCE TO INSTRUCTIONAL PRACTICE GUIDELINES 24

7.8.5A Activities focus on health-related components of fitness.

Skill related components of fitness are emphasized in their relation to skill development.

7.8.5B

Instructors within sections of the same course use common course

7.8 .6

outcomes.

89

$72(81)$

$9(10)$

$8(9)$

88

67 (76)

$14(16)$

7 (8)

85

$71(84)$

$8(9)$

$6(7)$

7.9.1A

The program has established exit outcomes which are listed on all course

7.9.1B

syllabi.

$88 \quad 63(72)$

$16(18)$

$9(10)$

Course content is related directly to exit outcomes.

$88 \quad 66(75) \quad 13(15)$

9 (10)

Note. Items in bold print indicate those items with the highest frequencies of "Not At All Adhered To" ratings. Items in italics indicate those items with the highest frequencies of "Fully Adhered To" ratings. 


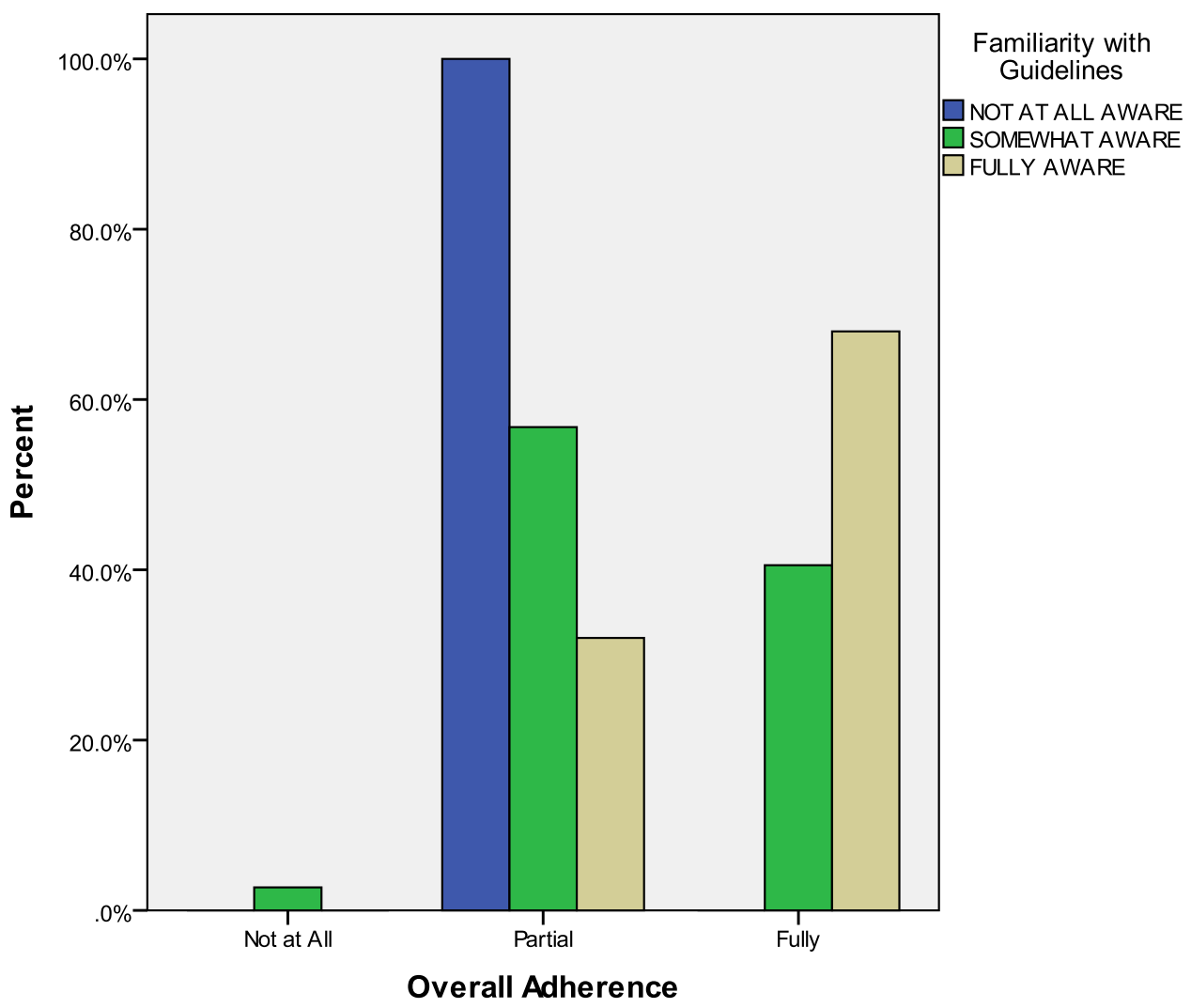

Figure 3. Association of Overall Adherence and Familiarity with the Guidelines $\chi^{2}(4, \mathrm{n}=90)=11.16, \mathrm{p}=.025$

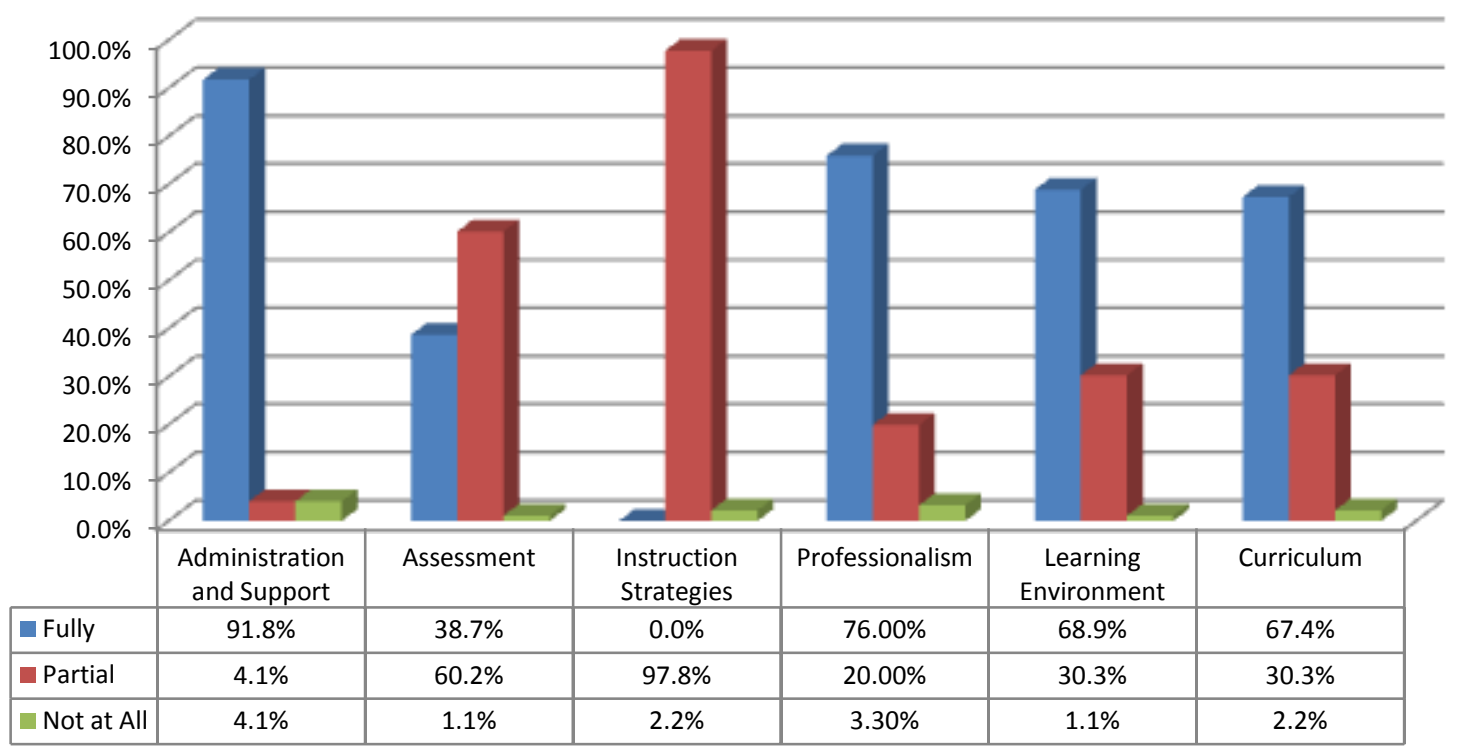

Figure 4. Adherence to Individual Categories Within NASPE Guidelines 


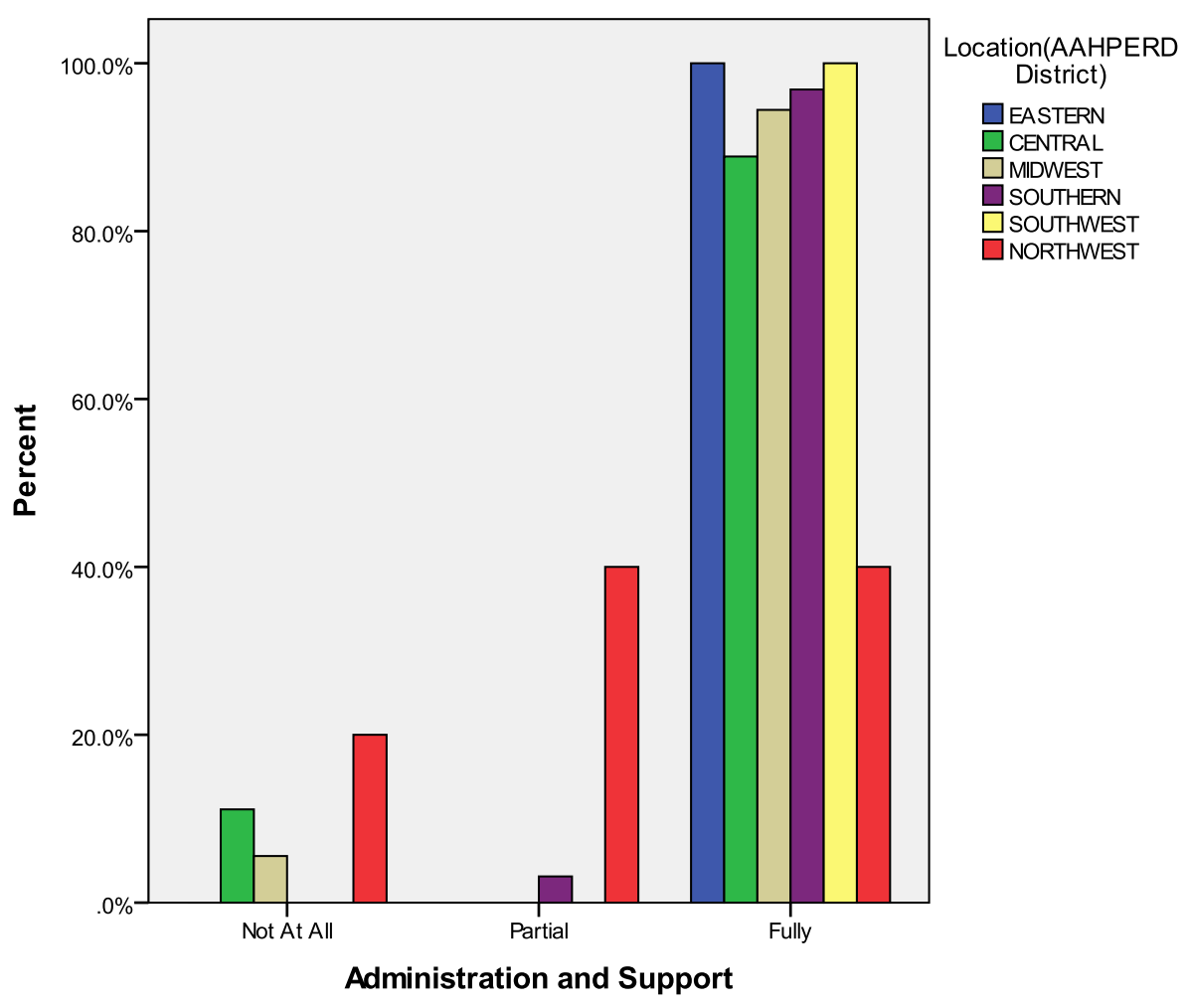

Figure 5. Association Between Adherence to Administration and Support and Location $\chi^{2}(10, \mathrm{n}=71)=23.98, \mathrm{p}=.008$

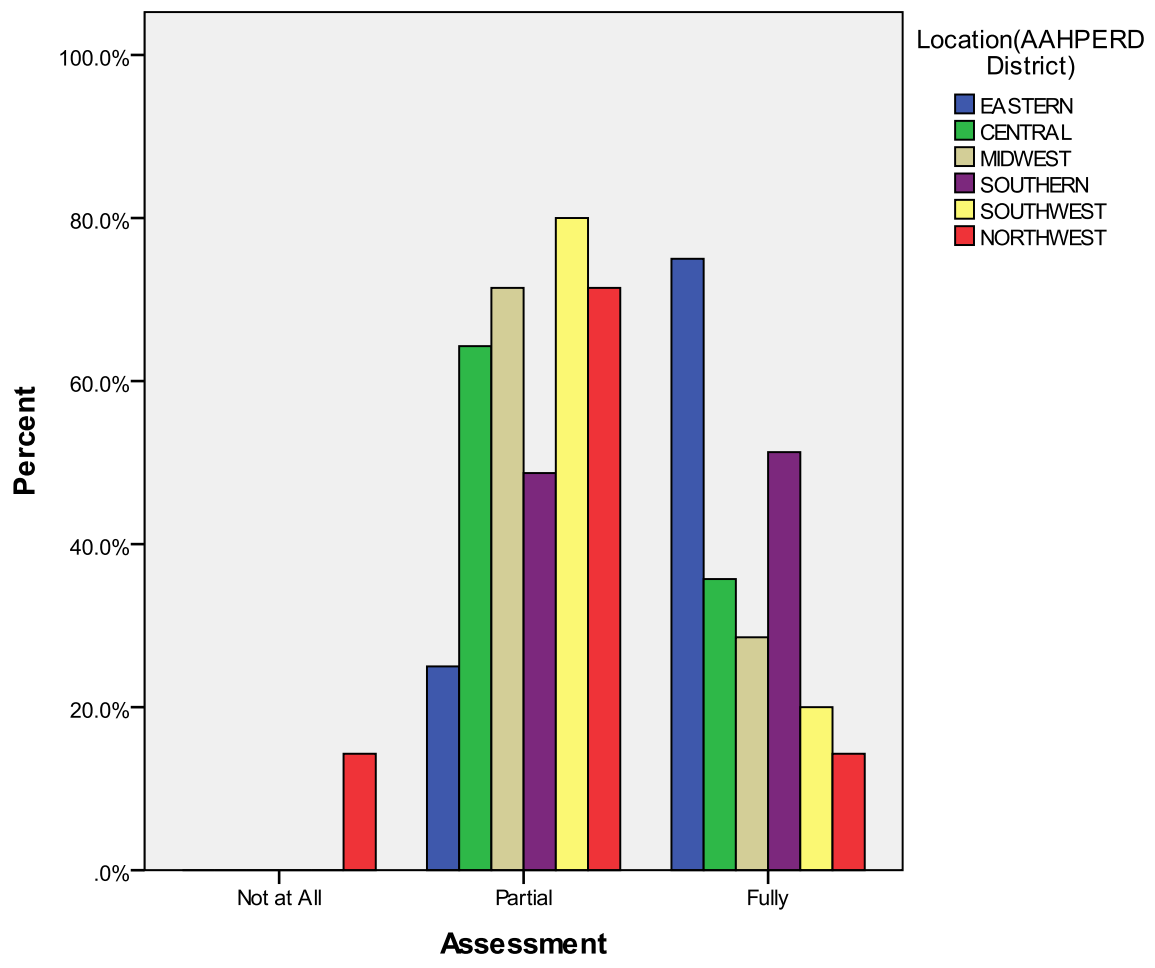

Figure 6. Association Between Adherence to Assessment and Location $\chi^{2}(10, \mathrm{n}=90)=19.39, \mathrm{p}=.036$ 
ADHERENCE TO INSTRUCTIONAL PRACTICE GUIDELINES 27

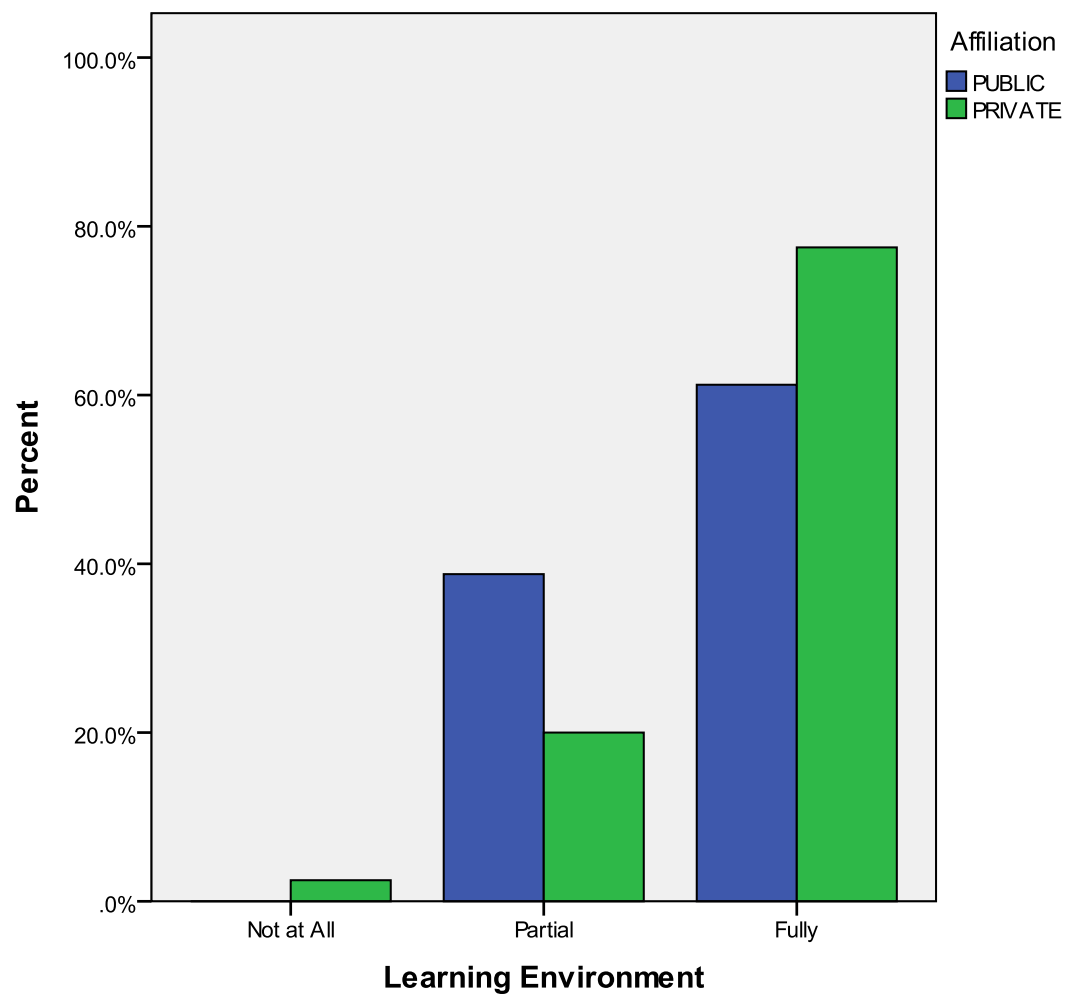

Figure 7. Association Between Adherence to Learning Environment and Affiliation $\chi^{2}(2, \mathrm{n}=90)=4.64, \mathrm{p}=.099$ 


\section{Discussion}

The purposes of this research study were to (a) determine the level of familiarity with those guidelines from NASPE's Appropriate Instructional Practice Guidelines for Higher Education Physical Activity Programs related to C\&I, and (b) describe the level of adherence to these selected guidelines. The results from this study indicate a high level of familiarity and adherence to the Guidelines. The geographic location of an institution appears to have an association with adherence in the areas of Administration/Support and Assessment. The results also support an association between awareness of and adherence to the Guidelines. To the researcher's knowledge, this is the first study that has gone beyond an examination of status and trends in HEPAPs, to determine adherence to a series of professionally developed guidelines and to compare findings among institutions based on demographic characteristics as well. The discussion is organized by Guideline category and observed level of adherence: (a) Higher Adherence (Administration/Support and Professionalism), (b) Partial Adherence (Learning Environment and Curriculum), and (c) Lower Adherence (Instruction Strategies and Assessment).

\section{Higher Adherence: Administration and Support and Professionalism}

The guidelines, in their entirety, were developed with the intent of providing a framework for optimizing HEPAP effectiveness, and, as such, adherence is not mandatory. The high level of awareness of the guidelines suggests HEPAP administrators are interested in promoting best practice and making a concerted effort to provide physical education opportunities that are developmentally appropriate, instructionally sound, and aligned with professional recommendations (NASPE, 2008). The association between awareness of and adherence to the guidelines supports the importance of advocacy efforts for quality physical education programs 
(McKenzie, 2007; NASPE, 2008). Continued advocacy, through the use of interdisciplinary teams composed of city government officials, city planners, community members, and faculty, has been suggested to further support and advance HEPAPs (Sweeney, 2011).

The high percentage of institutions fully adherent to the guidelines in the critical area of Administration and Support re-affirms the stability of HEPAPs on many college and university campuses (Hensley, 2000). Guideline 1.3.1 (The program adheres to course policies consistent with all other credit-bearing coursework within the institution, including those regarding instructor and student responsibilities and expectations, administrative roles, and standards of professionalism) had the highest percentage of fully adherent institutions of any of the 61 items included in this survey. This provides evidence of an administrative culture across institutions supportive of existing programs. The positive administrative culture displayed through these results may be valuable should HEPAP administrators attempt to implement changes to the program to address weaknesses related to areas such as assessment and effective instruction, discussed below. The high percentage of institutions fully adhering to this category should be interpreted with caution as the category contained a single item. The majority of guidelines related to Administration and Support were not included in the current study, as the purpose of this study was to examine adherence to the guidelines related to $\mathrm{C} \& \mathrm{I}$.

High adherence to the guidelines for Professionalism supports that, when given appropriate support and expectations, instructors within HEPAPs engage in appropriate professional practice. The high percentage of institutions adherent to the single item related to Administration and Support may be associated with the high percentage of institutions fully adherent to those items pertaining to Professionalism due to the emphasis on "standards of professionalism" explicitly stated in Guideline 1.3.1. Adherence to the Professionalism category 
should again be interpreted with caution as the category contained only three items.

Additionally, while adherence to the items related to Professionalism was high, closer examination of the wording of specific items (4.2.1A and 4.2.1B) may reveal that they may fit better with the items within Instruction Strategies category. Shifting these items into the Instruction Strategies category may result in a reduction in the high level of adherence seen in the Professionalism category and a subsequent increase in the Instruction Strategies category.

\section{Partial Adherence: Learning Environment and Curriculum.}

Adherence to the guidelines related to Learning Environment and Curriculum did not have the highest level of full adherence, nor did they have the lowest. The moderate percentage of institutions reporting full adherence to these categories indicates HEPAPs are proficient, but have yet to demonstrate mastery of these areas. Five of the ten guidelines with the highest percentages of institutions with full adherence are related to Learning Environment (5.1.3, 5.2.1A, 5.2.1B, 5.4.1, 5.5.1A, and 5.6.2B). These guidelines focus on environmental control, inclusivity, and safety of the learning environment, emphasizing management of the physical education setting. The pattern of higher adherence to the guidelines related to Learning Environment at private institutions is not surprising given the traditional emphasis on the teaching and learning environment there. The moderate level of full adherence to these management related guidelines is consistent with the low level of full adherence and the high level of partial adherence to the guidelines related to Instruction Strategies as effective class management is a component of effective teaching. The discrepancy, however, may be related to the courses offered in the individual HEPAPs. For example, outdoor pursuit or adventure courses, such as rock climbing, hiking, backpacking, kayaking, etc., require inherently higher 
levels of class management to maintain overall safety. It is plausible that programs offering courses like these are likely to have well managed classes, despite a lack of effective teaching.

Adherence to the guidelines related to Curriculum followed a similar pattern of adequacy, but lacking mastery. The items within the Curriculum category appear to be more related to administrative aspects of curriculum, such as program philosophy and program evaluation (7.8.1, 7.8.3, 7.8.6, 7.9.7A and 7.9.1B), as opposed to instructional aspects. The guidelines within this category do not prescribe a specific curricular model to follow, but rather, provide a general guide for the overall HEPAP curriculum. There is a strong connection between the development of course and program outcomes and assessment that is consistent throughout these guidelines. Adherence to these guidelines may serve as an opportunity for HEPAP administrators to forge a connection between the high administrative support and the lower adherence levels seen in the Assessment and Instruction Strategies guidelines. It is possible that adoption of a specific curricular model (i.e., Sport Education) may inherently promote effective instructional strategies and increased assessment (Meeteer, et al., 2011).

Adherence to the guidelines within this category have a high potential to significantly influence the PA of college students and are therefore of vital importance. This set of guidelines specifically addresses barriers to PA among college students including the development of social support networks, reasons for participation in PA (other than competition), and both cognitive and affective outcomes associated with PA (Buckworth \& Dishman, 2002; Nahas et al., 2003). The moderate level of adherence to these guidelines is promising, as HEPAPs appear to be meeting recommendations for health and fitness, including promotion of skill development, and affording students with opportunities to develop behavioral skills, knowledge, and supportive social networks. 


\section{Lower Adherence: Instruction Strategies and Assessment}

The percentage of responding institutions fully adherent to the guidelines related to Instruction Strategies $(\mathrm{n}=0,0 \%)$ highlights a previously identified problem: the lack of effective teaching in HEPAPs (Housner, 1993; Poole, 1993). The three individual guidelines with the highest levels of non-adherence of all items were from this category $(3.10 .1 \mathrm{~B}: 22 \%, \mathrm{n}=24$; 3.6.1B: $16 \%, \mathrm{n}=18 ; 3.3 .2: 16 \%, \mathrm{n}=18)$. The low level of adherence to the items within this category further supports concern about effective teaching within HEPAPs. The extremely high $(n=88,98.7 \%)$ level of partial adherence to this category indicates a variety of less than ideal instructional practices are taking place. The shift in course offerings to meet the changing needs of students and society, the trend of fewer full-time, tenure-track faculty teaching, and increased usage of activity specialists and graduate teaching assistants (Evaul \& Hilsendanger, 1993; Hensley, 2000) may be having a deleterious effect on the physical education of the general college student. Activity specialists, coaches, and graduate teaching assistants may be more knowledgeable about a specific activity in which they specialize, but they may lack adequate training in effective teaching strategies. Effective teaching requires intensive planning, and the ability to understand, utilize, and adapt complex teaching skills for individual students (Poole, 1993). Alternate approaches to traditional, command style teaching may be necessary to further the development of behavioral skills, knowledge, and the affective domain. Quality, in-service training and effective supervision have been suggested to assist graduate teaching assistants develop effective teaching skills (Poole, 1993) and may be appropriate for all HEPAP instructors in order to promote effective teaching practices. Training and supervision approaches, such as the four phase "instructor-development-and-support model" that is used at Auburn University 
(Russell, 2011, p.22), may be appropriate not only for graduate teaching assistants, but for all HEPAP instructors to develop effective teaching practices.

The increase in frequency and popularity of CBFW courses (Hodges Kulinna et al., 2009) may also be contributing to the low level of full adherence to the Instruction Strategy guidelines. While these courses include a PA laboratory, they also include didactic educational sessions. The wording of the guidelines is consistent with traditional physical education courses and settings, and may not be interpreted to be applied only during the laboratory portion of the CBFW courses.

The relationship between effective teaching and student outcomes should be investigated more thoroughly if the primary outcomes of HEPAPs are to continue to assist students in developing behavioral skills, behavioral capabilities, and to find meaning in PA. Unfortunately, calls for investigations of effective physical education programs in higher education have gone largely unheard for decades (Corbin, 2002; Housner, 1993). Adherence to the Guidelines related to Assessment had the second lowest percentage of responding institutions fully adherent $(\mathrm{n}=36$, 38.7\%). Guidelines 2.5.2 and 2.7.1, related to use of assessments and evaluations and assessing program effectiveness, had two of the highest percentages of non-adherence $(n=17,27 \%$ and $\mathrm{n}=17,15 \%$, respectively). Together, these data support the traditional lack of assessment and program evaluation in college and university physical education. Continual assessment, improvement, and re-evaluation of program offerings are not new concepts (Considine, 1985; Meztler and Tjeerdsma, 1998). Evidence in this study indicates program evaluation is not a priority. Given the high level of administrative support for HEPAPs, adoption of a systematic program evaluation process, such as the Development, Research, and Improvement (DRI) model (Metzler \& Tjeerdsma, 1998), may be beneficial not only for improvement of the individual 
HEPAP through increased accountability, but also to increase knowledge and understanding of program evaluation practices within HEPAPs. This study provides a foundation for evaluating HEPAPs, providing analyses that describe the context and design of HEPAPs, contributing to an understanding of the extent to which these Guidelines are being utilized. Investigations to examine program philosophy, goals, and outcomes would contribute additional evidence for HEPAP administrators to utilize when making decisions to restructure, revise, or maintain current practices. Investigations of the factors that influence the levels of familiarity and adherence seen in this study were not addressed, but should be investigated in future research as to provide a more comprehensive understanding of the variables that impact program evaluation. Program evaluation in HEPAPs should investigate the influence of the institutional mission statement and strategic plans, as well as establish program outcomes of what students achieve through participation in HEPAP offerings (Sweeney, 2011). Higher education physical activity program administrators that have a higher level of understanding of their program, and are better equipped and prepared to evolve due to changing educational and societal environments, will have programs that are less likely to face elimination and will continue to flourish. Evaluation and assessment of current HEPAPs is an initial step in the development, dissemination, and adoption of evidence based physical education programs (Sallis et al., 2012) necessary to define the role HEPAPs will serve in the promotion of participation in lifetime PA. Despite the considerable evolution in HEPAPs over the past 50 years (Hensley, 2000; Lumpkin \& Avery, 1986; Miller, Dowell, \& Pender, 1989; Oxendine, 1961, 1969, 1972, 1985; Oxendine \& Roberts, 1978; Trimble \& Hensley, 1984, 1990), the lack of focus on assessment and program evaluation may be contributing to a lack of effective teaching. 
While assessment in HEPAPs has traditionally focused on general program evaluation (Housner, 1993), only one of the guidelines relates directly to program evaluation, with the remaining emphasis on student assessment. Assessment of student knowledge, behavioral capabilities, and fitness has traditionally been conducted using an instructor designed, sometimes arbitrary approach (Housner, 1993). The practices recommended highlight the use of objective, regular, assessment with the intent of providing students with the information necessary to develop more educated consumers of and participants in PA. However, adherence to these recommendations is lacking, providing evidence that assessment practices may not have changed significantly over the past 30 years. The lack of adherence to the Assessment guidelines corresponds with the lack of adherence to the Instruction Strategy guidelines, as a basic tenant of effective teaching is the provision of feedback and assessment. This may be partially attributed to the individuals teaching HEPAP courses lacking training in effective teaching strategies as previously discussed. Additional in-service training, supervision, and professional development may provide instructors with information and strategies to increase teaching effectiveness, and subsequently, assessment practices (Russell, 2011). Incorporating electronic learningmanagement systems (LMS) may promote increased teaching effectiveness through increased instructor training capability, increased student assessment, and assist with program evaluation (Melton \& Burdette, 2011). Increased use of technology, such as pedometers and heart rate monitors, within HEPAP offerings would further assist instructors with assessment of student activity and increased ability to track student achievements, while simultaneously addressing adherence to guideline $3.10 .1 \mathrm{~B}$, the item with the highest level of non-adherence of all items in this study $(\mathrm{n}=22,24 \%)$. 
While familiarity was high across all institutions, the lack of adherence to recommendations for effective teaching in HEPAPs combined with the lack of adherence to recommendations for student assessment is especially concerning given the population. One of the underlying assumptions of this study was that institutions offering an undergraduate major in PETE would be more likely to be familiar with and adhere to recommendations for best practice due to the emphasis on preparation of future physical education teachers. However, the results of adherence to the guidelines from these two areas provide opportunity to question this assumption. Institutions offering an undergraduate major in PETE may have lower adherence in these areas due to an emphasis on instruction and assessment within the PETE program, potentially due in part to less focus on the practices within the HEPAP. Conversly, it is possible that institutions without an undergraduate PETE program may have higher adherence to the guidelines related to Instruction Strategies and Assessment as attention and resources would be channeled to the HEPAP. While these guidelines are intended to be a model of best practice for HEPAPs, the results indicate best practices are not occurring in two major areas of college-based physical education.

\section{Limitations}

The use of an internet based survey facilitated the administration and analysis of this research study. However, it contributed to a major limitation, low response rate. E-mail addresses were confirmed during the development of the population, resulting in few incorrect contacts and multiple follow-up messages were sent to facilitate participation. While lower than desired, the target response rate was reached (15-17\% target, $15.1 \%$ actual) and is consistent with published response rates (Hodges-Kulinna et al., 2009). It has been demonstrated that late respondents tend to be similar to non-respondents, and comparisons based on response groups 
may reveal useful information related to generalizability of the results (Miller \& Smith, 1983). Comparisons of early responders (those who responded after the initial contact, but before the second contact) and late responders (those who responded after the second contact) revealed data indicating no significant associations between response group and familiarity with the guidelines, overall adherence, nor adherence by category. With late respondents assumed typical of nonrespondents, the results discussed here may be generalized to the remainder of the population despite the low response rate (Miller \& Smith, 1983).

It is possible however, that participants that did not respond, or did not complete the survey fully, had lower familiarity and adherence to the Guidelines. It is also possible that those participants that did respond have greater familiarity and adherence, and as such, were more likely to respond, contributing to a response bias. The lack of association in comparisons of response groups (described above), increases the generalizability of the current study. Finally, investigating familiarity with and adherence to the Guidelines at all four year colleges or universities, not just those that offer an undergraduate major in PETE, is an area for future investigation. Examining familiarity with and adherence to the NASPE guidelines at all four year US colleges and universities may reveal differences between institutions with PETE programs and those without.

\section{Future Directions}

The results of this study combined with previous research, suggest that important similarities and differences exist across HEPAPs. The current study demonstrated a high level of familiarity and moderate levels of adherence with the NASPE Guidelines that focus on "Curriculum and Instructional Environment." This study was limited, however, to those Guidelines identified as being oriented toward C\&I leaving adherence to those related to A\&IS 
for future investigation. The current study expands the knowledge base related to HEPAPs, with additional investigations, utilizing a similar approach to the current study, contributing by developing a more thorough understanding of HEPAPs and the environments in which they exist. Future studies may assist in identifying strengths and areas in need of improvement within all ecological levels, in order to fully realize the potential of HEPAPs to promote PA. Investigations identifying adherence to the guidelines related to A\&IS may provide additional evidence of the influences of environmental variables such as facilities, budgeting, institutional culture or philosophy, and advocacy approaches.

These guidelines provide HEPAP administrators with a tool to use in the assessment of program quality. The Guidelines do not, however, identify specific models of best practice (i.e., those programs most adherent), models of HEPAPs that use data-based outcomes, nor those that can demonstrate the impact of the program on the students served. Program evaluation reports that follow the DRI model (Metzler \& Tjeerdsma, 1998) may be of research quality and would accomplish the goal of providing models of programs utilizing best practices. Additionally, by adhering to the DRI approach, data collected could be employed for data-based outcome assessments, and as such, demonstrate the impact of the program on student participation in PA and other outcomes identified through the program evaluation process. Identifying those programs fully adhering to the guidelines, and/or those having the largest impact on student participation in PA through an objective evaluation process may benefit all HEPAPs. The development, and adoption, of an external evaluation process to objectively examined adherence to these guidelines may provide an additional level of credibility to HEPAPs within the academic community and should be investigated. 
The application of social ecological perspectives in this study extends the current literature base exploring HEPAPs. Given that little research has been devoted to examining the influence of HEPAPs on college student PA, adherence to the categories from the Guidelines provides evidence for the use of social ecological perspectives to investigate HEPAPs. The association between geographic location and adherence to the guidelines related to Assessment and Administration and Support highlights the influence of institutional variables on HEPAPs. The percentages of institutions either partially or fully adhering to Guidelines related to Curriculum, Learning Environment, and Instruction Strategies emphasize the ability of HEPAPs to influence behavioral capability, behavioral skill, knowledge, and social support for students engaged in HEPAP course offerings. These individual level variables have been shown to be barriers to PA (Nahas et al., 2003), thus highlighting the potential for HEPAPs to influence PA of college students. The emphasis on the interaction of influences between levels, key to SEM, highlights the need to investigate both individual and environmental level variables more fully. The associations between geographic location and adherence to the guidelines related to Assessment, and Administration and Support, as well as the trend toward an association between affiliation and adherence to the guidelines related to Learning Environment revealed in this study provide evidence of environmental influences on HEPAPs. Future investigations should further explore the impact of HEPAPs on individual variables, but also the extent to which other environmental variables, such as community support, relationships with other organizations on campuses, and curricular models, influence HEPAPs. Combining the results of this investigation with future studies examining adherence to the guidelines related to A\&IS is necessary to identify those SEM variables most influential on HEPAPs and subsequently, college student PA. 
Investigation of the curricular models employed in HEPAPs has been neglected in the literature (Housner, 1993). Assessments of curricular models adopted, descriptions of the variables that influence the design and implementation of curricula, and examinations of the effectiveness of the curricula (Housner, 1993) continue to be needed. Future investigations including comparisons of the impact of curricular models may be necessary to determine their effectiveness in promoting lifelong PA.

\section{Conclusion}

Adherence to the NASPE Guidelines for Appropriate Instructional Practice related to "Curriculum and Instructional Environment" is moderate to high, as is familiarity with these guidelines. The high level of awareness and adherence indicates HEPAPs at institutions offering an undergraduate PETE program are engaging in appropriate instructional practice. College physical education programs have been called on to provide students with opportunities to develop an appreciation for, and increased participation in, lifetime PA; it appears that HEPAPs, with minor adjustments, are well prepared to provide these opportunities. 


\section{References}

Adams, T.M., \& Brynteson, P. (1995). The effects of two types of required physical education. Physical Educator, 52(4), 203-211.

American College Health Association [ACHA] (2001). American College Health AssociationNational College Health Assessment: Reference Group Data Report Fall 2000. Baltimore, MD: American College Health Association.

American College Health Association. [ACHA] (2011). American College Health AssociationNational College Health Assessment II: Reference Group Executive Summary Spring 2011. Hanover, MD: American College Health Association.

Brynteson, P., \& Adams, T.M. (1993). The effects of conceptually based physical education programs on attitudes and exercise habits of college alumni after 2 to 11 years of follow up. Research Quarterly For Exercise and Sport, 64, 208-212.

Buckworth, J., \& Dishman, R.K. (2002). Exercise psychology. Champaign, IL: Human Kinetics.

Calfas, K.J., Sallis, J.F., Lovato, C.Y., \& Campbell, J. (1994). Physical activity and its determinants before and after college graduation. Medicine, Exercise, Nutrition and Health, 3, 323-334.

Caspersen, C.J., Pereira, M.A., \& Curran, K.M. (2000). Changes in physical activity patterns in the United States, by sex and cross-sectional age. Medicine and Science in Sports and Exercise, 32(9), 1601-1609.

Centers for Disease Control and Prevention. (2001). Increasing physical activity: A report on recommendations of the Task Force on Community Preventive Services. Morbidity and Mortality Weekly Report, 50(No. RR-18), 1-14. 
Centers for Disease Control and Prevention \& American College of Sports Medicine. (1995). Physical activity and public health: A recommendation from the Centers for Disease Control and Prevention and the American College of Sports Medicine. Journal of the American Medical Association, 273, 402-407.

Considine, W.J. (1985). Basic instruction programs: A continuing journey. Journal of Physical Education, Recreation, and Dance, 56(7), 31-54.

Corbin, C.B. (2002). Physical activity for everyone: What every physical educator should know about promoting lifelong physical activity. Journal of Teaching in Physical Education, $21,128-144$.

Evaul, T., \& Hilsendanger, D. (1993) Basic instruction programs: Issues and answers. Journal of Physical Education, Recreation, and Dance, 64(6), 37-40.

Gay, L.R., Mills, G.E., \& Airasian, R. (2009). Survey research. In L.R. Gay, G.E. Mills, \& R. Airasian (Eds.), Educational Research; Competencies for Analysis and Applications. $9^{\text {th }}$ edition (pp.175-188). Columbus, OH: Pearson.

Hensley, L.D. (2000). Current status of basic instruction programs in physical education at American colleges and universities. Journal of Physical Education, Recreation, and Dance, 71(9), 30-36.

Hildebrand, K.M., \& Johnson, D.J. (2001). Determinants of college physical activity class enrollment: Implications for high school physical education. Physical Educator, 58(1), $51-57$.

Hinkin, T.R. (1998). A brief tutorial on the development of measure for use in survey questionnaires. Organizational Research Methods, 1(1), 104-121. 
Hodges-Kulinna, P., Warfield, W.W., Jonaitis, S., Dean, M., \& Corbin, C. (2009). The progression and characteristics of conceptually based fitness/wellness courses at American universities and colleges. Journal of American College Health, 58(2), 127-131.

Hunsicker, P.A. (1954). A survey of service physical education programs in American colleges and universities. Annual Proceedings of the College Physical Education Association, 57, 29-30.

Housner, L.D. (1993). Research in basic instruction programs. Journal of Physical Education, Recreation, and Dance, 64(6), 53-58.

Johanson, G.A., \& Brooks, G.P. (2010). Initial scale development: sample size for pilot studies. Educational and Psychological Measurement, 70(3), 394-400.

Kahanov, L., Furst, D., Johnson, S., \& Roberts, J. (2003). Adherence to drug dispensation and drug-administration laws and guidelines in collegiate athletic training rooms. Journal of Athletic Training, 38(3), 252-258.

Kahn, E.B., Ramsey, L.T., Brownson, R.C., Heath, G.W., Howze, E.H., Powell, K.E., Stone, E.J., Rajab, M.W., Corso, P., \& Task Force on Community Preventive Services. (2002). The effectiveness of interventions to increase physical activity. American Journal of Preventive Medicine, 22(4S), 73-107.

Kazdin, A.E. (2011). Single Case Research Design: Methods for Clinical and Applied Settings. $2^{\text {nd }}$ ed. New York, NY: Oxford University Press.

Leslie, E., Fotheringham, M.J., Owen, N., \& Bauman, A. (2001). Age-related differences in physical activity levels of young adults. Medicine and Science in Sports and Exercise, $33(2), 255-258$. 
Leslie, E., Sparling, P.B., \& Owen, N. (2001). University campus setting and the promotion of physical activity in young adults: lessons from research in Australia and the USA. Health Education, 101(3), 116-125.

Lumpkin, A., \& Avery, M. (1986). Physical education activity program survey. Journal of Teaching in Physical Education, 5(3), 185-197.

McInnis, K.J., Hayakawa, S., \& Balady, G.J. (1997). Cardiovascular screening and emergency procedures at health clubs and fitness centers. American Journal of Cardiology, 80, 380383.

McInnis, K.J., Herbert, W., Herbert, D., Herbert, J., Ribisl, P., \& Franklin, B. (2001). Low compliance with national standards for cardiovascular emergency preparedness at health clubs. Chest, 120, 283-288.

McKenzie, T.L. (2007). The preparation of physical educators: A public health perspective. Quest, 59, 346-357.

McLeroy, K.R., Bibeau, D., Steckler, A., \& Glanz, K. (1988). An ecological perspective on health promotion programs. Health Education Quarterly, 15(4), 351-377.

Meeteer, W., Housner, L.D., Bulger, S.M., Hawkins, A., \& Wiegand, R.L. (2011). Applying the Sport Education curriculum model in university basic instruction courses. In P. Hastie (Ed.) Sport Education International Perspectives. New York: Routledge.

Melton, B., \& Burdette, T. (2011). Utilizing technology to improve the administration of instructional physical activity programs. Journal of Physical Education, Recreation, and Dance, 82(4), 27-32. 
Metzler, M.W. \& Tjeerdsma, B.L. (1998). PETE program assessment within a development, research, and improvement framework. Journal of Teaching in Physical Education, 17(4), 468-493.

Miller, G.A., Dowell, L.J., \& Pender, R.H. (1989). Physical activity programs in colleges and universities: A status report. Journal of Physical Education, Recreation, and Dance, 60(6), 20-23.

Miller L.E., \& Smith, K. (1983). Handling non-response issues. Journal of Extension On-line, 21(5). Available at: http://www.joe.org/joe/1983september/83-5-a7.pdf

Nahas, M.V., Goldfine, B., \& Collins, M.A. (2003). Determinants of physical activity in adolescents and young adults: The basis for high school and college physical education programs to promote active lifestyles. The Physical Educator, 60(1), 42-56.

National Association for Sport and Physical Education [NASPE]. (2008). Appropriate Instructional Practice Guidelines for Higher Education Physical Activity Programs. $\left(2^{\text {nd }}\right.$ ed.). Reston, VA: National Association for Sport and Physical Education.

Oxendine, J.B. (1961). The service program in 1960-1961. Journal of Health, Physical Education, and Recreation, 32(6), 37-38.

Oxendine, J.B. (1969). Status of required physical education programs in colleges and universities. Journal of Health, Physical Education, and Recreation, 40(1), 32-35.

Oxendine, J.B. (1972). Status of general instruction programs of physical education in four-year colleges and universities: 1971-72. Journal of Health, Physical Education, and Recreation, 43(3), 26-28.

Oxendine, J.B. (1985). 100 years of basic instruction. Journal of Physical Education, Recreation, and Dance, 56(7), 32-36. 
Oxendine, J.B., \& Roberts, J.E. (1978). The general instruction program in physical education at four-year colleges and universities: 1977. Journal of Physical Education and Recreation, 49(1), 21-23.

Poole, J.R. (1993). The search for effective teaching in basic instruction programs. Journal of Physical Education, Recreation, and Dance, 64(6), 41-58.

Russell, J.A. (2011). Graduate teaching-assistant development in college and university instructional physical activity programs. Journal of Physical Education, Recreation, and Dance, 82(4), 22-32.

Sallis, J.F., \& Owen, N. (1999). Physical activity and behavioral medicine. Thousand Oaks, CA: Sage.

Sallis, J.F., Cervero, R.B., Ascher, W., Henderson, K.A., Kraft, M.K., \& Kerr, J. (2006). An ecological approach to creating active living communities. Annual Review of Public Health, 27, 297-322.

Sallis, J.F., \& McKenzie, T.L. (1991). Physical education's role in public health. Research Quarterly for Exercise and Sport, 62(2), 124-137.

Sallis, J.F., McKenzie, T.L., Beets, M.W., Beighle, A., Erwin, H., \& Lee, S. (2012). Physical education's role in public health: Steps forward and backward over 20 years and HOPE for the future. Research Quarterly for Exercise and Sport, 83(2), 125-135.

Sechrist, K.R., Walker, S.N., \& Pender, N.J. (1987). Development and psychometric evaluation of the exercise benefits/barriers scale. Research in Nursing and Health, 10, 403-425.

Slava, S., Laurie, D.R., \& Corbin, C.B. (1984). Long-term effects of a conceptual physical education program. Research Quarterly for Exercise and Sport, 55(2), 161-168. 
Spence, J.C., \& Lee, R.E. (2003). Toward a comprehensive model of physical activity. Psychology of Sport and Exercise, 4, 7-24.

Sparling, P.B. (2003). College physical education: an unrecognized agent of change in combating inactivity-related diseases. Perspectives in Biology and Medicine, 46(4), 579587.

Sparling, P.B., \& Snow, T.K. (2002). Physical activity patterns in recent college alumni. Research Quarterly for Exercise and Sport, 73, 200-205.

Stokols, D. (1992). Establishing and maintaining health environments; toward a social ecology of health promotion. American Psychologist, 47(1), 6-22.

Stokols, D. (1996). Translating social ecological theory into guidelines for community health promotion. American Journal of Health Promotion, 10(4), 282-298.

Sweeney, M.M. (2011). Initiating and strengthening college and university physical activity programs. Journal of Physical Education, Recreation, and Dance, 82(4), 17-21.

Trimble, R.T., \& Hensley, L.D. (1984). The general instruction program in physical education at four-year colleges and universities: 1982. Journal of Physical Education, Recreation, and Dance, 55(5), 82-89.

Trimble, R.T., \& Hensley, L.D. (1990). Basic instruction programs at four-year colleges and universities. Journal of Physical Education, Recreation, and Dance, 61(6), 64-73.

Trost, S.G., Owen, N., Bauman, A.E., Sallis, J.F., \& Brown, W. (2002). Correlates of adults' participation in physical activity: review and update. Medicine and Science in Sports and Exercise, 34, 1996-2001.

U.S. Department of Health and Human Services. (1996). Physical activity and health: A report of the Surgeon General. Atlanta, GA: U.S. Department of Health and Human Services, 
Centers for Disease Control and Prevention, National Center for Chronic Disease Prevention and Health Promotion.

U.S. Department of Health and Human Services. (2001). The Surgeon General's call to action to prevent and decrease overweight and obesity. Washington, DC: U.S. Department of Health and Human Services, Public Health Service, and Office of the Surgeon General. 


\section{Appendix A: Extended Literature Review}

This review of literature provides a rationale for the study. The conceptual framework is arranged into the following sections: (a) Physical inactivity and college students; (b) Social ecological model of health promotion; and (c) Higher education physical activity programs (HEAP) (also referred to as basic instruction programs (BIP) and/or college physical education).

\section{Physical Inactivity and College Students}

Despite the well-established benefits of physical activity (PA), roughly 50 percent of youth between 12 and 21 years of age are not physically active on a regular basis and approximately 14 percent report no PA at all (U.S. Department of Health and Human Services, 1996). It has also been shown that as age increases from childhood, progressing through adolescence and into adulthood, PA rates decline (Caspersen, Pereira, \& Curran, 2000). Findings from the National College Health Risk Behavior Survey (NCHRBS) (Centers for Disease Control and Prevention, 1997) demonstrate similar patterns with only 37.8 percent of students participating in vigorous PA on three to seven days per week. The PA levels observed among college-aged individuals also appear problematic, with 57 percent of males and 61 percent of females reporting no moderate or vigorous PA on at least three of seven days per week (American College Health Association, 2001). More recent data show 80.5 percent of college students do not meet American College of Sports Medicine and American Heart Association recommendations for moderate exercise and 73.7 percent do not meet recommendations for vigorous exercise per week (American College Health Association, 2011). Leslie, Fotheringham, Owen, and Bauman (2001) examined participation rates in moderate and vigorous PA of young Australian adults and found similar patterns among Americans of comparable ages. 
A 15 percent decline in vigorous activity and 10 percent decline in moderate PA was seen from 18-19 year old adults to the 25-29 years old.

This established decline in PA rates throughout the college years is particularly concerning due to the persistence of PA patterns from early adulthood into later adulthood. Sparling and Snow (2002), in a survey of recent college graduates found 85 percent of respondents who had regularly exercised as a college senior remained active at the same level or higher six years later. Additionally, 81 percent of those respondents who were not active as college seniors reported their PA level at or less than what it was during senior year. Due to the volume of evidence supporting the age related decline in PA, the American College Health Association (ACHA), has identified physical inactivity as a priority health risk for college students, calling for increased attention to promotion of PA on college campuses nationwide (ACHA, 2002). As such, college physical education programs have been identified as a potential arena for the development of healthy and physically active lifestyles.

However, the Task Force on Community Preventive Services (Kahn et al., 2002) cited "insufficient evidence" for college based physical education programs as PA intervention venues. The Task Force pointed out that the lack of evidence should not be interpreted as college physical education programs are ineffective, but rather, that additional investigations are necessary to provide evidence of effectiveness. The potential of HEPAPs to be an optimal venue for PA interventions due to their ability to influence large numbers of individuals has not yet been realized. In order for HEPAPs to remain viable, administrators must be able to demonstrate their value to students, alumni, and institutional leaders. 


\section{Social Ecological Model of Health Promotion}

Multiple approaches have been used to develop and implement interventions to increase PA levels of college students. A common criticism of intervention research is the lack of use of a sound theoretical approach in designing the intervention for behavior change. One particular theoretical framework which is appropriate for use in colleges and universities is the social ecological model. One key theory is the social ecological model. While certain theoretical models address only personal determinants and other models address only environmental determinants, the social ecological model addresses determinants and barriers of PA from multiple levels, thus making it appropriate for discussion with respect to PA promotion and the influence of the HEPAP on college student PA.

The social ecological model focuses on "the nature of people's transactions with their physical and sociocultural surroundings" (Stokols, 1992, p. 7). The model suggests multiple levels of interaction of behaviors and behavior settings. Behavior settings are the "social and physical situations in which behaviors take place" (Sallis \& Owen, 2002, p. 463). McLeroy, Bibeau, Steckler, and Glanz (1988) suggested the purpose of the model is to focus on and identify environmental causes of behavior and interventions to address these interactions.

The model has its roots in the work of Brofenbrenner (1979), who viewed behavior as being influenced by both individual and environmental determinants. He identified three levels of interactions between environment and individuals: the microsystem, mesosystem, and exosystem. The microsystem refers to interpersonal interactions such as family, social acquaintances and work groups. The mesosystem is defined as the interactions between family, school, and work. The broadest level of influence was defined as the exosystem, including such influences as cultural beliefs and values, political action, and economic forces. McLeroy et al. 
(1988) expanded on Brofenbrenner's model, providing more in depth analysis. They suggest patterned behavior is the focus, and that behavior influences and is influenced by five factors: (a) intrapersonal factors, (b) interpersonal factors, (c) institutional factors, (d) community factors, and (e) public policy (McLeroy et al., 1988).

Intrapersonal factors are defined as those influences related to biological and psychological variables, including developmental history (McLeroy et al., 1988). Interventions focusing solely on variables borrowed from psychological models assume the impetus for behavioral change lies within the individual, and neglect the influence of the social environment. However, interventions at the intrapersonal level utilize multiple levels of intervention such as peer counseling, incentives, or support groups, with the theory of changing individuals by targeting characteristics of the individual, "such as knowledge, attitudes, skills, or intentions to comply with behavioral norms" (McLeroy et al., 1988, p. 356).

Interpersonal factors refers to "relationships with family members, friends, neighbors, contacts at work, and acquaintances" (McLeroy et al., 1988, p. 356) and are salient influences of behavior. Social relationships are important resources, mediators of stress, and contribute to well being. Social support, including emotional support, informational support, tangible aid, and general assistance with "obligations and responsibilities" are valuable contributors to social identity. The use of interpersonal strategies for health promotion have generally attempted to alter behavior through social influences, as opposed to "changing the norms or social groups to which individuals belong" (p. 357). Interventions designed using this approach should influence the interpersonal factors which "encourage, support and maintain undesirable behaviors" (McLeroy et al., 1988, p. 359). 
Institutional factors include organizations, schools, health agencies, health care facilities and businesses or companies (McLeroy et al., 1988). Specifically, the role of organizational factors in an ecological perspective includes how the characteristics of the organization can support behavior, how organizational structure may be a target of change, and the "importance of organizational context" in the spread of promotion interventions. Due to the amount of time individuals spend associated with organizations (i.e., work, school, day care), the structure and function of an organization can exert significant influence, on the health and health related behaviors of its members. The social and economic support provided via organizations is also a significant source of influence. The social networks developed and the norms and values that spread serve as "mediators or mediating structures between individuals" and the environment (McLeroy et al., 1988, p. 360). The access, opportunity, and development of social support contribute to the attractiveness of organizations as behavioral change agents. Organizations are often used as agents of change in worksite wellness programs in order to promote healthier environments, as well as healthier employees. In the process of developing and implementing a health promotion program, the organization must first recognize a problem, identify and develop potential solutions, select a course of action, implement the program and ideally, over time, the program "becomes integrated into the organization" (p. 362). When integration occurs, the influence of the program and the organization is reciprocal. Organizational changes are "necessary to support long term behavioral changes among individuals," to create a culture of support, and are "prerequisites for the adoption, implementation, and institutionalization of health promotion programs" (McLeroy et al., 1988, p. 362).

Community factors involve the relationships between the institutional factors, including social networks, relationships among organizations, but within a defined area. The model 
proposed by McLeroy et al. (1988) defines community with three meanings: (a) "mediating structures" or "groups to which individuals belong," (b) "the relationships among organizations and groups within a defined area," and (c) a geographical and political focus "characterized by one or more power structures" (p. 363). The "mediating structures" refer to the social connections of a community, including neighborhoods, churches and volunteer groups. Due to the strong connections between the group and the individual, attempting to change individuals without support from the community is challenging. The relationships among organizations and groups within a geographical region influences health promotion mainly in terms of competition for resources. Political and power structures within communities may influence the definition of a health problem and the allocation of resources to address that problem.

The final construct of an ecological model for health promotion is public policy. Public policy refers to laws, statutes, and policies at the local, state, national and global levels. The use of laws, statutes and policies to "protect the health of the community" is considered as one of the strongest influences of public health (McLeroy et al. 1988, p. 365). Within this framework, developing policies, advocating for public health policies, and analyzing policies are essential roles for health promoters.

The primary purpose of an "ecological model is to focus attention on the environmental causes of behavior and to identify environmental interventions" (McLeroy et al., 1988, p. 366). They also advocate for health promotion programs to develop "environmental and organizational support...necessary for...implementation and ultimate institutionalization," the use of environmental approaches to complement individual behavior change programs, and "the importance of evaluating health promotion programs at multiple levels" (p. 366). Social 
ADHERENCE TO INSTRUCTIONAL PRACTICE GUIDELINES 55

ecological models stress that the effectiveness of an intervention is based on "the extent to which behavior contributes to health or illness" (McLeroy et al., 1988, p. 368).

Stokols (1992) stresses the importance of using an ecological approach to "provide environmental resources and interventions that promote enhanced well-being among occupants of an area" (p. 6). He also highlights five core principles of the social ecological perspective. First, ecological approaches recognize "environmental settings as having multiple physical, social, and cultural dimensions that can influence a variety of health outcomes" (Stokols, 1996, p. 285). Second, "human health is influenced not only by environmental circumstances but also by a variety of personal attributes" (p. 285). Social ecological approaches emphasize the relationships between these layers as opposed to focusing on only one aspect. Third, social ecological approaches attempt to understand "the dynamic relations between people and their environment" (p. 286). Fourth, social ecological approaches "emphasize the interdependence of environmental conditions within particular settings and the interconnections between multiple settings and life domains" (p. 286). Finally, social ecological perspectives are "inherently interdisciplinary" (p.286), providing the opportunity for integration of public health and epidemiological prevention strategies, individual level strategies of the medical model, and community wide interventions (Stokols, 1996).

\section{Social Ecological Models and Physical Activity}

Social ecological models have been recognized for their unique use in studying physical activity due to increasing complexity of current public health challenges (Sallis et al., 2006). Investigations of the characteristics of places that both promote and inhibit PA, as well as the "environmental and policy factors" that contribute to sedentary lifestyles have been identified as a priority. The emphasis on "cross-level analyses of health problems" and "incorporating two or 
ADHERENCE TO INSTRUCTIONAL PRACTICE GUIDELINES 56

more analytic levels" supports the use of social ecological theory to examine both individual and “aggregate manifestations of health problems" (Stokols, 1996, p. 287). Spence and Lee (2003) developed the Ecological Model of Physical Activity (EMPA) to identify "ecological determinants and correlates of physical activity" (p. 16). This model expands on the work of McLeroy et al. (1988) and Stokols $(1992,1996)$ by applying social ecological principals to the study of PA. Five hypotheses were developed highlighting the interconnectedness of the environment, biological and genetic factors, and psychological factors which influence PA. The EMPA provides a direct link for the application of social ecological models to the investigation of PA.

Social ecological approaches have been used in PA research to examine: the determinants of PA of Australians (Giles-Corti \& Donovan, 2002); the relative influence of determinants of PA for normal weight, overweight and obese individuals in Canada and the US (Blanchard et al., 2005); the influence of ecological variables on active living communities (Sallis et al., 2006); and the barriers to PA in students from seventh grade to first year college students (Gyurcsik, Spink, Bray, Chad, \& Kawn, 2006). One of the main benefits of examining PA using a social ecological approach is the potential for the environment to influence multiple individual behaviors, that is "if a change is made at one level of influence, all other levels may be affected" (Spence \& Lee, 2003, p. 9). Higher education physical activity programs have the potential to influence behavior of college students on intrapersonal, interpersonal, and institutional levels. The need to address issues related to individual characteristics, organizational influences, and policy decisions support the use of the social ecological model as a theoretical approach to addressing college student PA specifically. 


\section{Determinants of College Student Physical Activity}

A determinant is any factor which influences behavior (Nahas, Goldfine, \& Collins, 2003). The two general categories of determinants are facilitators and barriers. Facilitators are those factors which increase the likelihood of participation in PA. Consequently, barriers are those factors which reduce the likelihood of participation in PA. Buckworth and Dishman (2002) suggested six categories of determinants similar to the levels of the social ecological model: (a) demographic and biological factors, (b) psychological factors, (c) behavioral attributes and skills, (c) social and cultural factors, and (d) physical environment factors, and (e) physical activity characteristics. Demographic and biological factors include age, gender, occupation, general health status (including overweight/obesity, risk of heart disease), socioeconomic status, and race/ethnicity. Psychological factors include attitude, perceived barriers to exercise, intention, self-efficacy, enjoyment, locus of control, expected benefits, and knowledge of health and exercise. Behavioral attributes and skills include childhood activity patterns, dietary habits, stage of change assessments, school sports participation, smoking, and coping skills. Social and cultural factors include school class size, group cohesion, family influences, and social support from friends, spouse, family, and staff. Physical environment refers to access (actual, perceived, and at home), environmental conditions (climate), costs and safety. Physical activity characteristics are the intensity, duration, type, and self-assessed effort of an activity engaged in (Buckworth \& Dishman, 2002). Sallis and Owen (1999) suggested that the type and intensity of exercise may influence both facilitators and barriers to PA. There exists an extensive volume of literature investigating the determinants of PA. Due to the extensive nature of describing the impact of all determinants of PA, they will not be described here. For a comprehensive list and discussion of determinants of PA, see Trost, Owen, Bauman, Sallis, and 
Brown (2002) and Buckworth and Dishman (2002). The psychological and environmental determinants most relevant to college student PA are: self-efficacy, perceived barriers, and social support (Nahas et al., 2003).

Self-efficacy refers to the perceived ability of an individual to be successful completing or participating in PA. It is specific to the activity and may change based on the activity being attempted. Self-efficacy is one of the strongest predictors of future PA (Nahas et al., 2003), and has been used to predict activity levels in children, adolescents, and adults. College students are more likely to participate in PA that they feel they are competent in (Hildebrand \& Johnson, 2001).

Perceived barriers are identified by an individual, based on the perception of the individual and how he or she views or perceives the barrier. Barriers have been identified as personal (fatigue), situational (workload or weather conditions), or physical (lack of transportation, facilities or instruction) (Nahas et al., 2003). Perceived barriers to PA have been shown to exert a strong influence on the individual's PA behavior (Sallis \& Owen, 1999), determining how active or he or she becomes. The most commonly cited perceived barrier to PA is "lack of time," despite suggestions that "lack of time" is a convenient excuse for not being physically active (Nahas et al., 2003). Other perceived barriers include: lack of social support (family and/or spouse), lack of accessibility, inconvenient schedule, cost, aversion to PA, worries and competing demands (Calfas, Sallis, Lovato, \& Campbell, 1994; Sechrist, Walker, \& Pender, 1987). Those most commonly cited by college students include inconvenience (schedules and facilities), aversion, and competing demands (Calfas et al., 1994).

Social support is considered an interpersonal variable, influencing behavior both directly and indirectly. Direct social support refers to "situations such as exercising together or doing 
home tasks" (Nahas et al., 2003, p.50). Indirect support refers to talking or encouraging an individual to be more physically active. Social support from friends, family, or staff has been found to significantly influence PA (Sallis \& Owen, 1999).

Health behaviors of college students are subject to change and are influenced by a variety of social, cultural, and environmental factors. In general there is support for barriers to PA changing throughout the lifespan. Milestones such as graduating from high school, attending college, graduating from college and entering the workforce have implications as major transitions through life. Attending college or university "represents a major step toward personal independence" and serves as a time when "lifestyle choices are explored and tested" (Leslie et al., 200, p. 119). Changes in social contexts and differences in "social, psychological, biological [and] cultural factors, may influence" barriers to PA and subsequently, PA level (Calfas et al., 1994, p. 323). Leslie et al. (2001) suggested a change in priorities, increased time demands, due to employment and family situations, as well as environmental barriers such as access and cost, as plausible explanations. Calfas et al. (2000) suggested beginning a career, getting married, and starting a family as transitional influences to further explain the age related decline in PA.

\section{College Student Physical Activity Level and Patterns}

Healthy Campus 2010 (ACHA, 2002), identified physical inactivity as one of the six priority health risk behaviors requiring immediate action. Findings from the National College Health Risk Behavior Survey (NCHRBS) (Centers for Disease Control and Prevention, 1997) indicated only 37.8 percent of students participate in vigorous PA on three to seven days per week. Dinger (1999) reported 50\% of students fail to meet American College of Sports Medicine guidelines for adequate PA. More recently, data from the American College Health Association National College Health Assessment - II (ACHA, 2011) indicate 58 percent of 
college students reported no moderate or vigorous PA. Additionally, 48.3 percent of college students did not meet the American College of Sports Medicine and American Heart Association recommendation of 30 minutes of moderate PA on 5 or more days per week, or 20 minutes of vigorous PA on 3 or more days per week. Leslie et al. (2001) examined PA participation rates of young Australian adults and found similar patterns to Americans of similar ages. A $15 \%$ decline in vigorous activity and $10 \%$ decline in moderate PA was seen from 18-19 year old adults to 25 29 year old adults. Gender differences in PA observed in other age populations are similar in college aged individuals, with men reporting greater PA rates than women (U.S. Department of Health and Human Services, 1996) and higher vigorous PA rates. However, the decline in PA is observed earlier in females, especially in vigorous activity. The decline of vigorous PA has been shown to start in males around age 14, and for females around age 12. The lowest levels of vigorous PA for males occurred at age 21 and age 20 for females (Caspersen et al., 2000).

The investigation of college student PA levels highlights not only an immediate public health concern, but also a long term issue as health behaviors established during the college years have been shown to persist into adulthood. Sparling and Snow (2002), found 84.7 percent of those who exercised regularly as college seniors remained physically active 6 years later. Additionally, 81.3 percent of those who were not active as college seniors remained inactive. These data highlight the persistence of PA levels from the college years into early adulthood and emphasizes the need to establish healthy levels of PA during the college years.

Despite the primarily sedentary lifestyle that appears to characterize college living for many students, colleges and universities provide both opportunity and an environment that is favorable for establishing positive health behaviors (Sparling, 2003). In addition to the "built environment" (i.e., sidewalks, recreation facilities, green spaces), most colleges and universities 
provide physical environmental factors known to be positively associated with participation in PA including opportunity for activity, accessibility to facilities, safety, and aesthetic attributes. Higher education physical activity programs serve to influence knowledge, attitudes and behavioral skills of college students related to developing and maintaining a physically active lifestyle. The combination of environmental and personal strategies provides significant potential for colleges and universities to be influential in the establishment of healthy PA behaviors in this time of transition to independent living. Higher education physical education, in the form of a diverse, positive format may be able to influence college students of all PA levels. The historical background of the HEPAP, combined with more recent trends in programming and curricula further support the potential for the HEPAP to promote PA in college students. The following section will review the literature investigating HEPAPs in order to provide a deeper understanding of their future potential.

\section{Higher Education Physical Activity Programs}

Basic instruction programs have existed in institutions of higher education since the late 1800s, when the first physical education program was established at Amherst College in Massachusetts (Considine, 1985; Oxendine, 1985). The initial purpose of the BIP was to provide students with a coping mechanism to help "deal with the rigors of their academic work" (Lumpkin \& Jenkins, 1993, p. 33). Through the use of European gymnastic elements, instructors attempted to increase strength, endurance and the overall health of their students. The University of Pennsylvania became the first major institution of higher education to require physical education for all students for 4 years as well as pass a swimming competency in order to graduate (Oxendine, 1985). World War I served as a significant influential force on required physical education. "One third of men drafted for military service were rejected as unfit to 
serve" (p.32). Military leaders argued that low fitness levels diminished the ability of American men to serve effectively and ultimately reduced their ability to survive "the hardships of a war" (p. 32). Consequently, the time period from 1900 to 1930 saw an increase in the number of required physical education programs. Male and female physical education departments were separate, and as such, females focused on team and individual sports, while males focused on the team sports they coached. The overall emphasis of BIPs during this time was away from overall health and fitness, toward "psychomotor, character and intellectual objectives of the whole person" (Oxendine, 1985, p. 33).

The time from 1930 to 1950 was marked by significant growth for BIPs. Athletic departments and physical education departments merged, physical education's role in general education was linked via educational objectives, and the BIP was again used as an avenue to develop fitness, strength, and endurance of future soldiers to prepare them for war. The majority of colleges and universities required physical education, most for 2 or more years (Oxendine, 1985).

Following the conclusion of World War II, athletic departments separated from physical education programs primarily for financial reasons. An increase in the emphasis of the doctoral degree in physical education contributed to the initiation of the use of graduate assistants teaching within the BIP. Men's physical education programs were dominated by a competitive team sports emphasis, while women's programs focused on skill instruction and recreational activities.

The BIP of the 1960s and 1970s looked more like modern programs. Lifetime sports became popular, teaching assistants were used, fewer coaches taught, and team sports continued, as competition among females was gaining acceptance. From 1970 to 1980, the overall number 
of institutions requiring physical education decreased, resulting in a decrease in the number of BIPs. However, students demanding additional freedom and control over their educational experience, forced remaining programs to shift curricular offerings toward fitness, outdoor activities, and lifetime sports (Oxendine, 1985). The overall purpose of the BIP again shifted from personal development to "fun, lifetime skill development and fitness" (p.34). From an administrative viewpoint, more classes were taught by teaching assistants, as doctoral trained faculty focused on higher level academic courses. Male coaches continued to teach, while female teachers started to coach. Students asked for activity courses which required specifically qualified instructors, such as scuba diving, skiing, and rock climbing.

From 1980 until the 1990s, the emphasis shifted in response to changing societal beliefs toward the development and maintenance of fitness and the inherent value of participation in physical activity in any form throughout lifespan. "Health-related outcomes again became the primary purpose" (Oxendine, 1985, p. 36) of the BIP. Administratively, the trend of using graduate teaching assistants, reduced faculty involvement, increased adjunct faculty usage, and increased budgetary pressure to be cost-effective continued.

Trimble and Hensley (1990) and Hensley (2000) continued the evaluation of changes within the BIP, reporting similar trends as previous investigations. The details of these investigations are discussed as they relate to trends in the BIP in the sections below. In general, the number of required programs decreased, the number of part-time faculty and graduate teaching assistants increased, course offerings continued to move toward individual, lifetime sports and activities, and the number of concepts based BIP courses grew.

From 2000 to 2011, even less is known. Shifts in curricular offerings have resulted in increased use of combination traditional lecture/physical activity laboratory courses (Hodges- 
Kulinna, 2009). However, little research has focused on HEPAPs since Hensley (2000). While it is likely changes have continued to take place, the form and extent of these changes has not been described in the literature. The historical perspective of HEPAPs provides a background for trends that have occurred over the same 100 years. However, examining trends within the HEPAPs provides additional insight into the evolution and potential of the HEPAP to serves as a PA promotion arena.

\section{Trends in Higher Education Physical Activity Programs}

Hunsicker (1954) published the first assessment of the BIP (referred to as service physical education programs at the time). The original survey, gathered information related to: the requirement status of physical education (86 percent of institutions required physical education for at least 1 year, with 57 percent requiring physical education for 2 years); credit granted for physical education courses (77 percent yes); grading procedure (66 percent letter, 11

percent numerical and 23 percent pass/fail); the requirement of a swimming proficiency (70 percent no); common course offerings, the use of waivers (92 percent no); fitness testing (66 percent no); skill testing (60 percent no); knowledge testing (48 percent no); and questions related to the use of standard tests for fitness and/or activities. This original survey provided insight into the BIP nationwide and served as a baseline to track changes from the 1950s to 2000. From this initial investigation, the following themes were evaluated in subsequent investigations: institutional information (enrollment and affiliation), status of required physical education, assessment procedures, faculty involvement (including the use of graduate teaching assistants, coaches, and adjunct faculty), and curricular offerings.

Institutional size, affiliation, and physical education requirements. Hunsicker (1954) reported 90 percent of responding institutions had some requirement for physical education for 
graduation. Greene (1955) reported 94 percent of responding institutions had such a requirement for graduation. Fornia (1959) reported 88 percent of public institutions and 64 percent of private institutions had co-educational programs, with the Southwest United States having the highest number. Additionally, she found similar results with regard to a graduation requirement, reporting 95 percent "of total respondents indicated that physical education was required for graduation" (p. 427), with both public and private affiliated institutions reporting similar results.

Oxendine (1961) was the first to examine the impact of institutional size "to determine if requirements and practices were influenced by enrollment" (p. 37). He reported data similar to Hunsicker (1954), with 84 percent of institutions requiring physical education for graduation. However, there was no association between institutional size and the status of a requirement. Oxendine (1969) reported 87 percent of institutions required physical education. Oxendine (1972) stated 95 percent of institutions included physical education in their curricula, with 74 percent reporting physical education as a requirement for graduation. This decrease signified the start of a downward trend that would not be reversed until the 1980s. This decrease was consistent among both public and private institutions, with larger institutions being less likely to maintain the requirement than smaller institutions. The decline in the requirement of physical education was reported again by Oxendine and Roberts (1978), with 57 percent of responding institutions having physical education as a graduation requirement. Similar to the 1972 results, larger, public institutions were more likely to drop the requirement than were smaller, private institutions. While the number of institutions requiring physical education for graduation decreased, the number of students electing to take classes in the BIP increased from the late 1970s to the mid-1980s, highlighting the interest of college students in BIP course offerings (Oxendine \& Roberts, 1978; Trimble \& Hensley, 1984). 
Trimble and Hensley (1984) continued the investigation of BIP, reporting 94 percent of respondents offer physical education to their students. A slight increase to 60 percent of institutions requiring physical education was also reported, with smaller institutions reporting a higher percentage than larger institutions. More private institutions continued to maintain the requirement than did public institutions. Miller, Dowell, and Pender (1989), reported 92 percent of responding institutions at that point required physical education, down slightly from 1984 . Forty-five percent of institutions reported having a physical education requirement, up slightly from 1984. Again, smaller institutions were more likely to require physical education than were their larger counterparts. However, no comparison between affiliations was made in this investigation. Trimble and Hensley (1990) re-examined the availability of BIPs, reporting 92 percent of reporting institutions provided some form of physical education to the general student. Sixty five percent of the respondents indicated physical education was required, indicating "the trend to eliminate the physical education requirement... has not only been abated, but appears to have been reversed" (p. 66). Hensley (2000), once again evaluated the status of a requirement of physical education for graduation and found 63 percent of respondents indicated it was required. Smaller institutions continued to maintain the requirement compared to larger institutions. Overall, from 1954 until 1972, the percentage of institutions requiring physical education for graduation remained fairly high, decreasing steadily until 1978, rising slightly until 1990, and then decreasing at the start of the $21^{\text {st }}$ century. The trend of large, public institutions to eliminate required physical education for graduation was consistent over time, as was the trend for smaller, private institutions to maintain a physical education requirement.

Credit granting and waivers. Hunsicker (1954) reported 77 percent of respondents granted academic credit for physical education classes. This remained consistent, with Greene 
(1955) reporting 78 percent of institutions awarded academic credit, with some credit being granted (or waived) for military service. The percentage of institutions awarding academic credit for physical courses rose to as high as 90 percent (Oxendine, 1972) and remained stable and high throughout the 1970s, 1980s, 1990s, and into 2000 (Oxendine \& Roberts, 1978; Trimble \& Hensley, 1984; Miller et al., 1989; Trimble \& Hensley, 1990; Hensley, 2000). The granting of waivers for required physical education remained quite low, most commonly reported as less than 1 percent of responding institutions. The most common reasons provided for the provision of a waiver included military service, varsity sports participation, and medical reasons. The number of institutions requiring physical education that had a specific statement not allowing waivers increased to 19 percent in 1990, suggesting changes in curricular offerings afforded all students the opportunity to participate (Trimble \& Hensley, 1990).

Assessment procedures, grading practices, and student evaluation. Grading and assessment in the BIP has remained largely unchanged. Hunsicker (1954) reported the majority of institutions using letter grades (66 percent), followed by pass or fail ( 23 percent), and numerical (11 percent). Oxendine (1961) reported 74 percent of respondents used letter grades with small institutions more likely to use pass/fail grading. Knowledge, fitness, and skill assessments were administered more frequently at smaller institutions compared to large institutions. Ten years later, while the use of letter grades remained relatively unchanged, the use of skill and fitness tests increased to 61 percent of institutions (Oxendine, 1969). Another shift in grading practices occurred a few years later with 41 percent of institutions reporting the use of pass/fail or credit/no credit grading systems (Oxendine, 1972). "Physical performance exams" were reported to be used more often than not, but a decrease in their use was reported in 1969. Several years later, proficiency testing or competency testing continued to rise (41 
percent, compared to 34 percent in 1972), with larger institutions more likely to incorporate testing into the courses (Trimble \& Hensley, 1984). Letter grading was reported as most frequently used (62 percent) with pass/fail grading decreasing from 31 percent to 24 percent, suggesting a tightening of grading practices, and a "more structured, more traditional approach" (Trimble \& Hensley, 1984, p.85). The time period from the late 1980s until 2000 revealed little change in grading practices (Miller et al., 1989; Trimble \& Hensley, 1990; Hensley, 2000). However, the use of proficiency exams did decrease slightly. More specific information related to student assessment in BIP courses is not available and leaves unanswered questions as to the evaluation practices and philosophies employed in the BIP.

More recently, Sweeney (2011) and Melton and Burdette (2011) discuss the role, and importance, of assessment in the BIP. Sweeney (2011) discussed the importance of both student assessment and program outcomes, emphasizing the importance of BIP philosophical alignment with institutional philosophy and program advocacy in order to contribute to the development of overall college student health. Melton and Burdetter (2011) take a different approach, however, addressing the use of technology to improve efficiency in assessment of students and in program evaluation. The use of electronic learning management systems, pedometers, and heart rate monitors are suggested as methods to facilitate technology use into BIP courses and programs, while simultaneously increasing assessment and evaluation practices (Melton \& Burdette, 2011).

Faculty involvement, graduate teaching assistants, and teaching effectiveness. While the line of research investigating the BIP began in 1954, it was not until Oxendine (1969) that questions related to teaching staff were introduced. However, the data are limited, stating only that 59 percent of institutions increased the size of their teaching staff in response to larger enrollments. Oxendine and Roberts (1978) reported the percentage of tenure track faculty 
teaching in the BIP at 42 percent. From this time period until 2000, the trend of tenure-track faculty teaching in the BIP continually declined. Larger institutions were more likely to report fewer tenure-track faculty teaching, but higher percentages of non-tenure track faculty, adjunct faculty, activity specialists, and graduate teaching assistants (Oxendine \& Roberts, 1978; Trimble \& Hensley, 1984; Miller et al., 1989; Hensley, 2000). Smaller institutions were more likely to report coaches and dual role individuals teaching within the BIP (Miller et al., 1989). A shift in and the growth of the curricular offerings of the BIP (discussed below), contributed to the increase in adjunct faculty with unique sport skill or experience in order to better meet student needs. The use of non-tenure track faculty, adjunct instructors, activity specialists, and graduate teaching assistants within the BIP has been an area of concern in relation to effective teaching in the BIP.

Evaul and Hilsendanger (1993) reported that "less than 10 percent of the service programs in large universities are taught by full-time faculty, with the majority being taught be [graduate assistants] (64\%) and the rest by part-time faculty and coaches" (p. 37). They suggested the tendency of isolated, "second-class status" programs may be attributed to less involvement of full-time faculty. Poole (1993) suggested graduate teaching assistants may be subject to role conflict as they are expected to serve as "part-time teachers while also enrolled as full-time graduate students" (p. 41). Selection, training, and mentoring of graduate teaching assistants have been identified as potential issues facing BIP administrators when utilizing them for teaching BIP courses (Evaul \& Hilsendanger, 1993). Poole (1993) recommended additional in-service training development for graduate teaching assistants. Continuing to explore the preparation and training of graduate teaching assistants, Russell (2008a) investigated perceptions of graduate teaching assistants regarding a supervisory system utilizing video analysis and 
conferencing. The results revealed a higher level of preparedness and confidence teaching and an appreciation for exposure to the process of supervision and evaluation. Russell suggested further research be conducted examining "the socialization and development" (p. 19) of GTAs as their role continues to expand in BIPs. Russell (2011) expanded on the training, supervision and evaluation of GTAs, describing a four phase "instructor-development-and-support model" that is used at Auburn University. The four phases follow those suggested by Evaul and Hilsendanger (1993) as being imperative to GTA effectiveness: recruitment, pre-teaching preparation, preteaching orientation, and in-service development and support.

The BIP has also been identified as a potential source of research on effective teaching (Housner, 1993; Poole, 1993). Despite this potential, few institutions (2 percent) report utilizing the BIP for research purposes (Trimble and Hensley, 1990). De Knop (1986) examined teacher behaviors using university students enrolled in tennis camp. The students were grouped into a more effective class and a less effective class as determined via a skills test. The results of direct observation of behavior revealed significant differences in learning time in class, specific feedback provided, and receiving information. Buck, Harrison, and Bryce (1990) utilized a BIP course to investigate the relationship between learning and achievement of volleyball skills. A skills pre-test was administered, learning trials were tabulated for 22 class sessions and a skills post-test was then administered to determine the students' level of achievement. The results revealed total correct trials was the only significant factor in determining achievement of volleyball skills. The results highlighted the need "to structure the environment to improve the probability that more correct trials for all skills will occur" (Buck, et al., p. 151). Whether focused on the individuals providing the instruction, the instruction itself, or the composition of 
the instructional faculty, the literature exploring teaching and teachers within the BIP provides additional support for the evaluation of BIPs.

Program objectives, philosophy, and outcomes. Not until Trimble and Hensley (1990) were objectives, philosophies, or outcomes of BIPs investigated. Seventy-nine percent of institutions reported having an official statement or objectives. Respondents were asked to rank order the three most important purposes of the BIP from a provided list. The purposes of the BIP identified as being most important were: (a) developing a commitment to lifelong participation; (b) fitness and health development; and (c) helping students enjoy participation in PA. These purposes were "generally consistent irrespective of size of the institution or its affiliation" (Trimble \& Hensley, 1990, p. 66). Hensley (2000) expanded on this investigation, asking respondents to "rate the importance of selected outcomes and purposes of their BIPs using a fivepoint Likert Scale" (p. 34). Similar to Hensley and Trimble (1990), the most important outcomes were to: (a) develop a commitment to lifelong participation; (b) develop an enjoyment of PA; (c) fitness and health development; and (d) "help students understand the importance of movement in their lives" (Hensley, 2000, p. 34). Institutional size and affiliation again, had no impact on these outcomes, emphasizing that the main outcomes of the BIP are consistent and "have not changed very much over the last 10 to 12 years" (Hensley, 2000, p. 34).

Literature investigating the outcomes associated with BIPs has focused on perceptions of outcomes, reasons for enrollment, and student evaluation of the BIP. Boyce, Lehr, and Baumgartner (1986) assessed student perceptions of a series of outcomes generated by BIP faculty using a Likert-scale survey. Student perceptions of outcomes and benefits received from participating in BIP courses were compared to the "benefits and outcomes generated by an expert committee" (p. 290). The results indicated "students perceived their courses were beneficial" (p. 
284) in achieving the outcomes developed by the BIP faculty, with 12 of the 15 outcomes being perceived similarly by students and committee members. Boyce et al. (1986) recommended obtaining student input for further development and improvement of BIPs.

In order to assess students' reasons for enrolling in BIP courses, Kisabeth (1986) surveyed students enrolled in BIP classes. The results revealed "significant differences by gender, activity class, and perceived skill level" for the purposes students' enrolled in BIP courses. This information may be of use to curricular designers and instructors in BIPs to facilitate understanding and to "accommodate the various students" who take BIP courses (p. 153). Savage (1998), Russell (2008b), and Hardin, Andrew, Koo, and Bemiller (2009) also surveyed students in BIP courses to assess their motivation for participation. The results from both studies were similar to the outcomes reported by Trimble and Hensley (1990) and Hensley (2000): fitness development, enjoyment, and skill development remained as primary motivating factors for participation in a BIP course. Academic benefit was an additional motivating factor identified by Hardin et al. (2009), predicting behavioral intentions in males. Taken collectively, the results indicate students' reasons for enrolling in BIP courses was largely unchanged over the past twenty years.

Literature examining student satisfaction with BIPs indicates those participating in the BIP are generally satisfied with the program/course (Crawford, Greenwell, \& Andrew, 2007; Lumpkin \& Avery, 1986; Russell, 2008b). Course content and the instructor were found to significantly influence satisfaction (Crawford et al., 2007). The results of these studies provide support to the argument that students will participate in the BIP if they perceive it to be of a high quality and they are satisfied with the quality of the experience. This provides promise for BIP administrators in light of decreasing numbers of BIPs, offerings, and student enrollment. 
ADHERENCE TO INSTRUCTIONAL PRACTICE GUIDELINES 73

Changes in preferred offerings and student perceptions necessitate regular examination and evaluation of the program "to be sure it is relevant to students' needs and interests" (Lumpkin \& Avery, 1986, p. 196).

Curricular offerings. Examination of the curricular offerings of BIPs began with Hunsicker (1954). Swimming was reported with the highest frequency (10.9 percent) followed by basketball (7.3 percent) and volleyball (6.7 percent). The majority of the curricular offerings during this time were individual and dual sports. Moving into the 1960s, Oxendine (1961) reported individual and dual sports, gymnastics, aquatics, and rhythmic activities increased since 1954, whereas team sports declined significantly with a more pronounced decline in larger institutions. This signified the beginning of a decline in team sports offerings in BIPs that persisted through the 1990 s and into the 21 st century. As team sports declined, "recreational," "fitness and weight control," and "lifetime and individual type" curricular offerings were reported more frequently (Oxendine, 1969, 1972; Oxendine \& Roberts, 1978). Oxendine and Roberts (1978) reported fitness oriented courses (jogging, aerobics) and outdoor activities (backpacking, hiking, rock climbing), racquet sports, dance and winter sports (skiing) as more popular novel BIP offerings. Course offerings continued to reflect student interests: individual sports and fitness activities were most frequently offered; team sports continued to decline (Trimble \& Hensley, 1984).

As BIPs continued to evolve in response to societal and student interests, fitness-related and individual sport course offerings continued to be reported as most commonly offered (Miller et al., 1989). The emergence of "multi-dimensional" health related fitness courses with a “cognitive component (p. 68) was observed, with a tendency to make such courses a requirement unto themselves (see more below on Concepts Based Fitness/Wellness courses) (Trimble \& 
Hensley,1990). The trend of the "multi-dimensional" concepts based health and wellness course grew, as Hensley (2000) reported 52 percent of responding institutions required such a course, with smaller institutions more likely to require this type of course than larger ones and $60 \%$ offered this type of course within the BIP (Hensley, 2000). Due to the increasing trend of required concepts based health and wellness courses, the following section will provide a more in depth exploration.

\section{Concepts based fitness/wellness courses. Concepts-based Fitness/Wellness (CBFW)} courses are courses offered by higher education institutions (Hodges-Kulinna et al., 2009). Conceptual information related to health, wellness, fitness, behavior change strategies, and selfmanagement skills are developed in the lecture component; engagement in a variety of activities is emphasized in the PA laboratory. Originally developed in the 1960s, CBFW courses did not become entrenched in the academic or physical education departments until the late 1970s and early 1980s. It has been suggested that these courses can be used to develop skills, attitudes, knowledge and contribute to the adoption of health behaviors (Pearman et al., 1997). Trimble and Hensley (1990) first reported the trend of institutions offering a "multi-dimensional" course to satisfy a PE requirement. Hensley (2000) reported this percentage to be $60 \%$ of responding institutions, and Hodges-Kullinna et al. (2009) reported a significant increase to $90 \%$ of responding institutions offering a $\mathrm{CBFW}$, suggesting the trend predicted by Trimble and Hensley (1990) had become reality.

Research focused on CBFW has focused primarily on the ability of the CBFW course to impact college students' health-related behaviors. Slava, Laurie, and Corbin (1984) compared the knowledge, attitudes and activity profiles of students who had taken a CBFW course to those who had not, finding significant differences between the groups, with the CBFW groups having 
higher knowledge and activity scores. While traditional sports-based curricula inherent to college physical education programs may not provide adequate PA opportunities to those not skilled in the specific sport, positive change in PA behaviors as well as improvements in attitudes toward PA have been seen in conceptually based physical education offerings (Brynetson \& Adams, 1993). Adams and Brynteson (1995) found significant differences in the perceptions of the value of a CBFW course in terms of knowledge of fitness, attitude toward fitness, the value of exercise, and current exercise habits of recent college alumni who had taken a CBFW course compared to those who had taken a traditional activity based courses. Sparling (2003) suggested CBFW courses as an agent of change for unhealthy behaviors of college students, continuing to support the increased percentage of institutions offering such courses. The long term impact of CBFW courses has yet to be explored, however, the combination of the trend of increased CBFW offerings, the ability of CBFW courses to have a significant impact on knowledge and attitude toward PA and increased PA levels, suggests CBFW courses may play a significant role in the transition of HEPAPs to promote PA and serve college students' needs.

The promotion of lifelong participation in and an appreciation of PA is one of the commonly stated goals of HEPAPs. Based on available literature highlighting college student PA levels, HEPAPs may not be sufficiently promoting PA among college students. This disconnect between expected outcomes and actual outcomes leads to questions of the effectiveness of HEPAPs. Researchers have called for evaluation of college physical education programs in order to determine their impact on students (Avery \& Lumpkin, 1986; Evaul \& Hilsendanger, 1993; Leslie et al., 2001; Sparling, 2003). The National Association for Sport and Physical Education (NASPE) published a series of guidelines to be used by HEPAP administrators as a self-measure of quality, addressing a majority of the trends described above. 
The following section will discuss the evolution of the NASPE guidelines and their potential to be used as tool to evaluate HEPAPs.

National Association of Sport and Physical Education Guidelines for HEPAPs. The NASPE (1998) developed the first version of guidelines for HEPAP administrators to use "to facilitate and promote the use of practices that are in the best interests of college-aged students (appropriate) and to avoid those that are counterproductive or even harmful (inappropriate)" (p. 2). The first edition recommended five philosophical underpinnings for HEPAPs including having education as the central mission, emphasizing health-related PA and skill development, sensitivity to students' and societal needs, and promoting the value of lifelong participation in PA. The guidelines are organized in five content areas including: (1) administration and support, (2) curriculum, (3) instruction, (4) assessment, and (5) faculty standards. Within each of the content areas are forty statements consisting of an appropriate practice and an inappropriate practice, which define the guideline. To facilitate the use of these guidelines as a program evaluation tool, a "program appraisal rating scale" was included. Program administrators could rate each guideline as being either "fully met," "partially met," or "not met" (p. 12), providing a subtotal for each content area as well as an overall total. Utilizing the tool, administrators were encouraged to identify those guidelines being fully complied with as well as "to identify strategies to improve those guidelines where non-compliance could be a concern" (p. 12). The second edition, published in 2008, expanded and clarified the position of NASPE with respect to "best practice" in HEPAP. The intent of these guidelines remained similar: to “educate professionals about effective programming and teaching within a higher education curriculum" (p. 3). The overall goals remained the same, with the guidelines to be used for assessment of the "quality of instruction" of the program and as a framework to develop an 
effective program. Content areas remained similar to the first edition, however, the total number of guidelines increased to 74. The content areas of assessment, instructional strategies (instruction in the first edition), program staffing (faculty standards in first edition), and curriculum were expanded from the first edition. Content areas of professionalism and learning environment were added. The professionalism content area contains guidelines related to appearance/presentation, teaching, growth and advocacy. The learning environment area consists of guidelines including instructor planning, class management, safety, diversity, equity, inclusion, and socialization in sport/PA. The program appraisal tool included in the first edition was removed. The guidelines presented in the second version "represent pedagogical and administrative practices" to be used for program assessment, and offer "minimum standards for program administration and quality of instruction" (p. 6).

\section{Summary}

The need for constant assessment, improvement of teaching, and evaluation of program offerings in light of changing societal influences provide support for additional assessments of BIPs and HEPAPs. Despite what is known about HEPAP trends, little has been done to assess the quality of the HEPAPs. The NASPE guidelines for HEPAPs offer a framework to evaluate the potential of an HEPAP to promote participation in lifetime PA. To date, there are no published investigations of the level of adherence of HEPAPs to these guidelines. Therefore, utilizing the NASPE guidelines as a foundation to develop an assessment tool for HEPAPs may provide valuable information to program administrators to establish the level of quality of the HEPAP and potentially be used to promote PA of college students. 


\section{References}

Adams, T.M., \& Brynteson, P. (1995). The effects of two types of required physical education. Physical Educator, 52(4), 203-211.

American College Health Association [ACHA] (2001). American College Health AssociationNational College Health Assessment: Reference Group Data Report Fall 2000. Baltimore, MD: American College Health Association.

American College Health Association [ACHA]. (2002). Healthy Campus 2010: Manual. Baltimore, MD: American College Health Association.

American College Health Association [ACHA]. (2011). American College Health AssociationNational College Health Assessment II: Reference Group Executive Summary Spring 2011. Hanover, MD: American College Health Association.

Blanchard, C.M., McGannon, K.R., Spence, J.C., Rhodes, R.E., Nehl, E., Baker, F., \& Bostwick, J. (2005). Social ecological correlates of physical activity in normal weight, overweight, and obese individuals. International Journal of Obesity, 29, 720-726.

Boyce, B.A., Lehr, C., \& Baumgartner, T. (1986). Outcomes of selected physical education activity courses as perceived by university students. Journal of Teaching in Physical Education, 5, 280-292.

Brofenbrenner, U. (1979). The Ecology of Human Development. Cambridge, MA: Harvard University Press.

Brynteson, P., \& Adams, T.M. (1993). The effects of conceptually based physical education programs on attitudes and exercise habits of college alumni after 2 to 11 years of follow up. Research Quarterly For Exercise and Sport, 64(2), 208-212. 
Buck, M., Harrison, J.M., \& Bryce, G.R. (1990). An analysis of learning trials and their relationshop to achievement in volleyball. Journal of Teaching in Physical Education, 10, $134-152$

Buckworth, J., \& Dishman, R.K. (2002). Exercise psychology. Champaign, IL: Human Kinetics.

Calfas, K.J., Sallis, J.F., Lovato, C.Y., \& Campbell, J. (1994). Physical activity and its determinants before and after college graduation. Medicine, Exercise, Nutrition and Health, 3, 323-334.

Calfas, K.J., Sallis, J.F., Nichols, J.F., Sarkin, J. A., Johnson, M.F., Caparosa, S., Thompson, S., Gehrman, C.A., \& Alcaraz, J.E. (2000). Project GRAD: two year outcomes of a randomized controlled physical activity intervention among young adults. American Journal of Preventive Medicine, 18(1), 28-37.

Caspersen, C.J., Pereira, M.A., \& Curran, K.M. (2000). Changes in physical activity patterns in the United States, by sex and cross-sectional age. Medicine and Science in Sports and Exercise, 32(9), 1601-1609.

Centers for Disease Control and Prevention. (1997). Youth risk behavior surveillance: National college health risk behavior survey_United States, 1995. Morbidity and Mortality Weekly Report. 46(SS-6), 1-54.

Centers for Disease Control and Prevention. (2001). Increasing physical activity: a report on recommendations of the Task Force on Community Preventive Services. Morbidity and Mortality Weekly Report. 50(No. RR-18), 1-14.

Considine, W.J. (1985). Basic instruction programs: A continuing journey. Journal of Physical Education, Recreation, and Dance, 56(7), 31-54 
Crawford, S.Z., Greenwell, T.C., \& Andrew, D.P. (2007). Exploring the relationship between perceptions of quality in basic instruction programs and repeat participation. Physical Educator, 64(2), 65-73.

DeKnop, P. (1986). Relationship to specified instructional teacher behaviors to student gain on tennis. Journal of Teaching in Physical Education, 5, 71-78.

Dinger, M.K. (1999). Physical activity and dietary intake among college students. American Journal of Health Studies, 15(3), 139-148.

Evaul, T., \& Hilsendanger,D. (1993) Basic instruction programs: Issues and answers. Journal of Physical Education, Recreation, and Dance, 64(6), 37-40.

Fornia, D.L. (1959). Coedcuational physical education in institutions of higher learning. The Research Quarterly of the American Association for Health, Physical Education, and Recreation, 30(4), 423-429.

Giles-Corti, B., \& Donovan, R.J. (2002). The relative influence of individual, social, and physical environmental determinants of physical activity. Social Science and Medicine, $54,1793-1812$.

Greene, M.M. (1955). Physical education as a college graduation requirement. Journal of Health, Physical Education, and Recreation, 26(9), 25-26.

Gyurcsik, N.C., Spink, K.S., Bray, S.R., Chad, K., \& Kwan, M. (2006). An ecologically based examination of barriers to physical activity in students from grade seven through firstyear university. Journal of Adolescent Health, 38, 704-711.

Hardin, R., Andrew, D.P., Koo, G., \& Bemiller, J. (2009). Motivational factors for participating in basic instruction programs. Physical Educator, 66(2), 71-85. 
Hensley, L.D. (2000). Current status of basic instruction programs in physical education at American colleges and universities. Journal of Physical Education, Recreation, and Dance, 71(9), 30-36.

Hildebrand, K.M., \& Johnson, D.J. (2001). Determinants of college physical activity class enrollment: Implications for high school physical education. Physical Educator, 58(1), $51-57$

Hodges-Kulinna, P., Warfield, W.W., Jonaitis, S., Dean, M., \& Corbin, C. (2009). The progression and characteristics of conceptually based fitness/wellness courses at American universities and colleges. Journal of American College Health, 58(2), 127-131. Housner, L.D. (1993). Research in basic instruction programs. Journal of Physical Education, Recreation, and Dance. 64(6), 53-58.

Hunsicker, P.A. (1954). A survey of service physical education programs in American colleges and universities. Annual Proceedings of the College Physical Education Association, 57, $29-30$

Kahn, E.B., Ramsey, L.T., Brownson, R.C., Heath, G.W., Howze, E.H., Powell, K.E., Stone, E.J., Rajab, M.W., Corso, P., \& Task Force on Community Preventive Services. (2002). The effectiveness of interventions to increase physical activity. American Journal of Preventive Medicine, 22(4S), 73-107.

Kisabeth, K.L. (1986). Basic instruction programs: A search for personal meaning. Physical Educator, 43, 150-154.

Leslie, E., Fotheringham, M.J., Owen, N., \& Bauman, A. (2001). Age-related differences in physical activity levels of young adults. Medicine and Science in Sports and Exercise, $33(2), 255-258$ 
Leslie, E., Sparling, P.B., \& Owen, N. (2001). University campus setting and the promotion of physical activity in young adults: Lessons from research in Australia and the USA. Health Education, 101(3), 116-125.

Lumpkin, A., \& Avery, M. (1986). Physical education activity program survey. Journal of Teaching in Physical Education, 5(3), 185-197.

Lumpkin, A., \& Jenkins, J. (1993). Basic instruction programs: A brief history. Journal of Physical Education, Recreation, and Dance, 64(6), 33-36.

McLeroy, K.R., Bibeau, D., Steckler, A., \& Glanz, K. (1988). An ecological perspective on health promotion programs. Health Education Quarterly, 15(4), 351-377.

Melton, B., \& Burdette, T. (2011). Utilizing technology to improve the administration of instructional physical activity programs. Journal of Physical Education, Recreation, and Dance, 82(4), 27-32.

Miller, G.A., Dowell, L.J., \& Pender, R.H. (1989). Physical activity programs in colleges and universities: A status report. Journal of Physical Education, Recreation, and Dance, $60(6), 20-23$.

Nahas, M.V., Goldfine, B., \& Collins, M.A. (2003). Determinants of physical activity in adolescents and young adults: The basis for high school and college physical education programs to promote active lifestyles. The Physical Educator, 60(1), 42-56.

National Association for Sport and Physical Education (NASPE). (1998). Guidelines for Appropriate Practice in College/University Physical Activity Programs. Reston, VA: National Association for Sport and Physical Education. 
National Association for Sport and Physical Education (NASPE). (2008). Appropriate Instructional Practice Guidelines For Higher Education Physical Activity Programs. ( $2^{\text {nd }}$ ed.). Reston, VA: National Association for Sport and Physical Education.

Oxendine, J.B. (1961). The service program in 1960-1961. Journal of Health, Physical Education, and Recreation, 32(6), 37-38.

Oxendine, J.B. (1969). Status of required physical education programs in colleges and universities. Journal of Health, Physical Education, and Recreation, 40(1), 32-35.

Oxendine, J.B. (1972). Status of general instruction programs of physical education in four-year colleges and universities: 1971-72. Journal of Health, Physical Education, and Recreation, 43(3), 26-28.

Oxendine, J.B. (1985). 100 years of basic instruction. Journal of Physical Education, Recreation, and Dance, 56(7), 32-36.

Oxendine, J.B., \& Roberts, J.E. (1978). The general instruction program in physical education at four-year colleges and universities: 1977. Journal of Physical Education and Recreation, $49(1), 21-23$

Pearman, S.N., Valois, R.F., Sargent, R.G., Saunders, R.P., Drane, J.W., \& Macera, C.A. (1997). The impact of a required college health and physical education course on the health status of alumni. Journal of American College Health, 46(2), 77-85.

Poole, J.R. (1993). The search for effective teaching in basic instruction programs. Journal of Physical Education, Recreation, and Dance, 64(6), 41-58.

Russell, J.A. (2008a). An examination of kinesiology GTAs' perceptions of an instructional development and evaluation model. Physical Educator, 65(1), 2-20. 
Russell, J.A. (2008b). Utilizing qualitative feedback to investigate student perceptions of a basic instruction program. Physical Educator, 65(2), 68-82.

Russell, J.A. (2011). Graduate teaching-assistant development in college and university instructional physical activity programs. Journal of Physical Education, Recreation, and Dance, 82(4), 22-32.

Sallis, J.F., \& Owen, N. (1999). Physical activity and behavioral medicine. Thousand Oaks, CA: Sage.

Sallis, J.F., \& Owen, N. (2002). Ecological models of health behavior. In: Glanz, K., Rimer, B.K., \& Marcus-Lewis, F. (Eds.) Health Behavior and Health Education ( ${ }^{\text {rd }}$ Edition). pp. 462-470). San Francisco, CA: Jossey-Bass

Sallis, J.F., Cervero, R.B., Ascher, W., Henderson, K.A., Kraft, M.K., \& Kerr, J. (2006). An ecological approach to creating active living communities. Annual Review of Public Health, 27, 297-322.

Savage, M.P. (1998). University students' motivation for participation in a basic instruction program. College Student Journal, 32(1), 58-66.

Sechrist, K.R., Walker, S.N., \& Pender, N.J. (1987). Development and psychometric evaluation of the exercise benefits/barriers scale. Research in Nursing and Health, 10, 403-425.

Slava, S., Laurie, D.R., \& Corbin, C.B., (1984). Long-term effects of a conceptual physical education program. Research Quarterly for Exercise and Sport, 55(2), 161-168.

Sparling, P.B. (2003). College physical education: an unrecognized agent of change in combating inactivity-related diseases. Perspectives in Biology and Medicine, 46(4), 579587. 
Sparling, P.B., \& Snow, T.K. (2002). Physical activity patterns in recent college alumni. Research Quarterly for Exercise and Sport, 73, 200-205.

Spence, J.C., \& Lee, R.E. (2003). Toward a comprehensive model of physical activity. Psychology of Sport and Exercise, 4, 7-24.

Stokols, D. (1992). Establishing and maintaining health environments; toward a social ecology of health promotion. American Psychologist, 47(1), 6-22.

Stokols, D. (1996). Translating social ecological theory into guidelines for community health promotion. American Journal of Health Promotion, 10(4), 282-298.

Sweeney, M.M. (2011). Initiating and strengthening college and university physical activity programs. Journal of Physical Education, Recreation, and Dance, 82(4), 17-21.

Trimble, R.T., \& Hensley, L.D. (1984). The general instruction program in physical education at four-year colleges and universities: 1982. Journal of Physical Education, Recreation, and Dance, 55(5), 82-89.

Trimble, R.T., \& Hensley, L.D. (1990). Basic instruction programs at four-year colleges and universities. Journal of Physical Education, Recreation, and Dance, 61(6), 64-73.

Trost, S.G., Owen, N., Bauman, A.E., Sallis, J.F., \& Brown, W. (2002). Correlates of adults' participation in physical activity: review and update. Medicine and Science in Sports and Exercise, 34(12), 1996-2001.

U.S. Department of Health and Human Services. (1996). Physical activity and health: A report of the Surgeon General. Atlanta, GA: U.S. Department of Health and Human Services, Centers for Disease Control and Prevention. 


\title{
Appendix B: Item Selection Instrument
}

\section{Assessment of Appropriate Instruction Practice Guidelines for}

\author{
Higher Education Physical Activity Programs
}

The purpose of this assessment is to categorize a list of statements adapted from the NASPE Appropriate Instruction Practice Guidelines for Higher Education Physical Activity Programs ( $2^{\text {nd }}$ edition, 2009). This assessment is the first step in a project to assess the level of adherence of Higher Education Physical Activity Programs to the NASPE guidelines. The following categories regarding these guidelines have been developed and are defined below.

\section{Curriculum and Instruction (C\&I):}

a. Those guidelines which have a direct influence on student behaviors, student outcomes, student knowledge, student abilities, and/or student skill development

b. Items may include, but are not limited to guidelines related to areas such as: effective teaching, lesson structure, practice opportunities, maximizing physical activity, instructional strategies, instructor behaviors, etc.

\section{Administration and Institutional Support (A\&IS):}

a. Those guidelines which are departmental, program, or institutional administrative functions and/or those statements which do not have a direct influence on student behaviors, outcomes, knowledge, abilities, and/or skill development

b. Items may include, but are not limited to guidelines related to areas such as: program position, marketing, promotion, staffing, professional development, program evaluation, assessment, policy and procedures, etc.

\section{Unclassified:}

a. Those items that do not fit the C\&I $\underline{\text { OR }}$ A\&IS definitions stated above

\section{Instructions for Completion:}

Using the definitions provided, please select the most appropriate category for each statement. Place an " $\mathrm{X}$ " in the box corresponding to the category in which you feel the statement best belongs.

\begin{tabular}{|l|l|l|l|}
\hline \multicolumn{1}{|c|}{ Statement } & C \& I & A \& & Unclassified \\
\hline
\end{tabular}




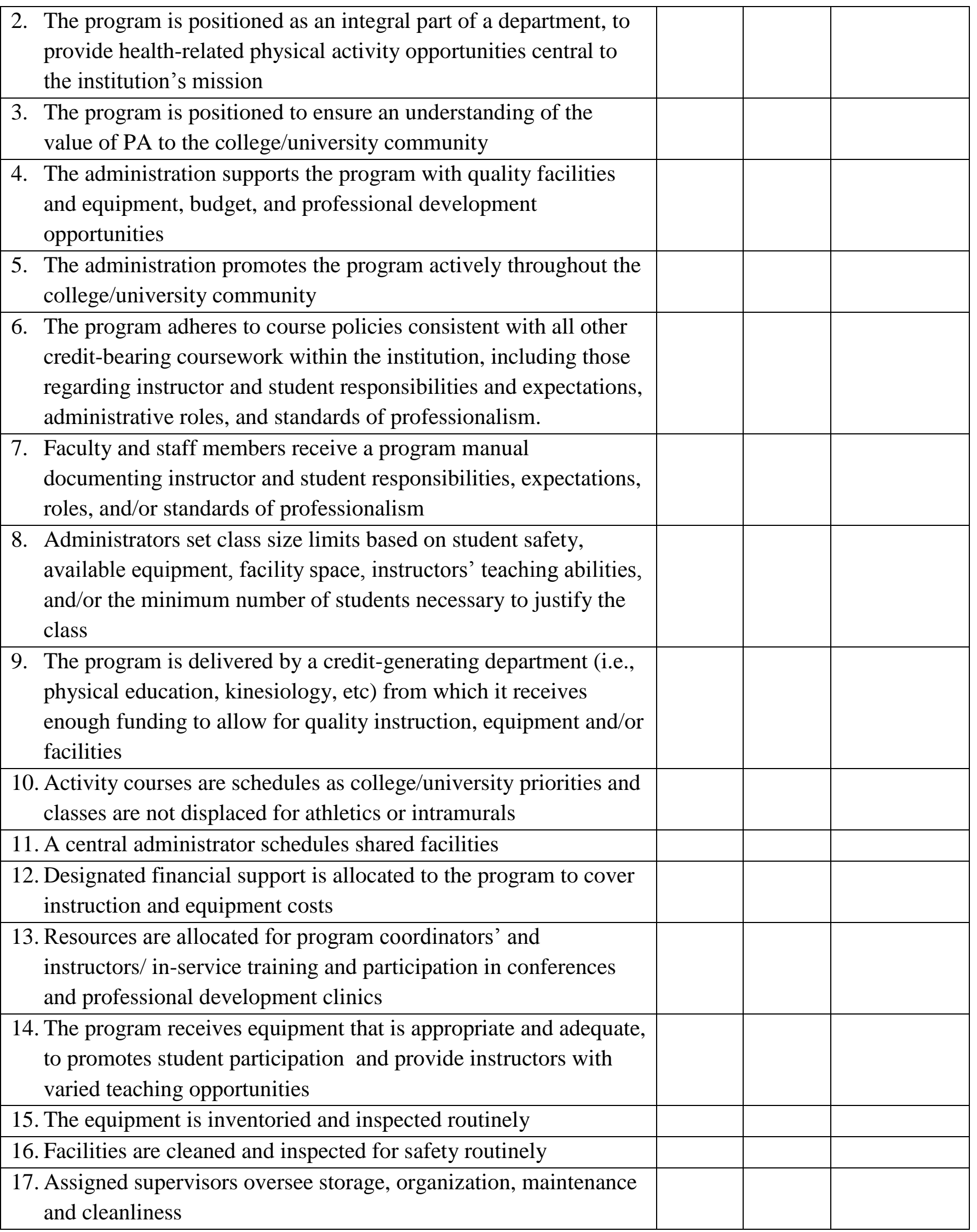




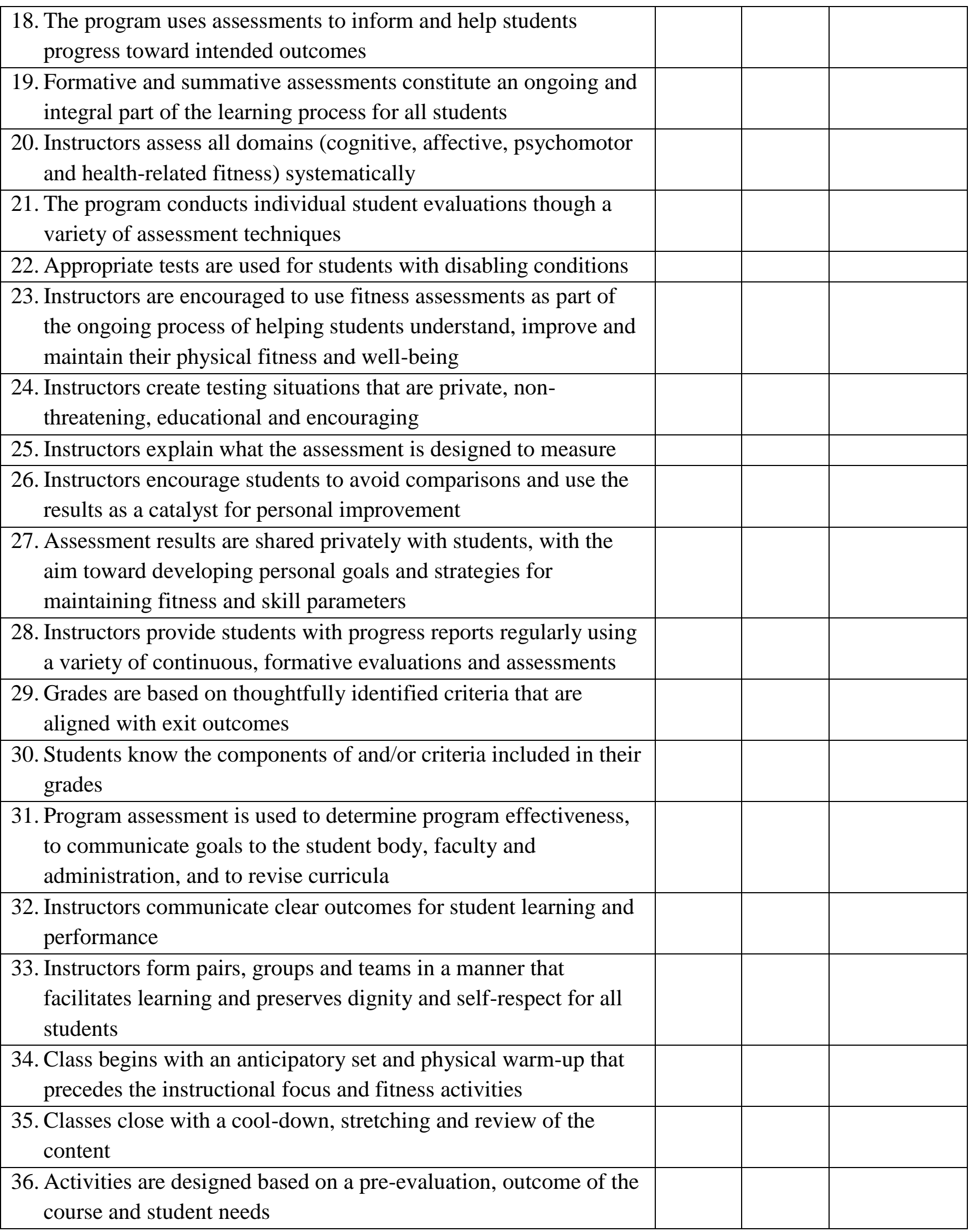




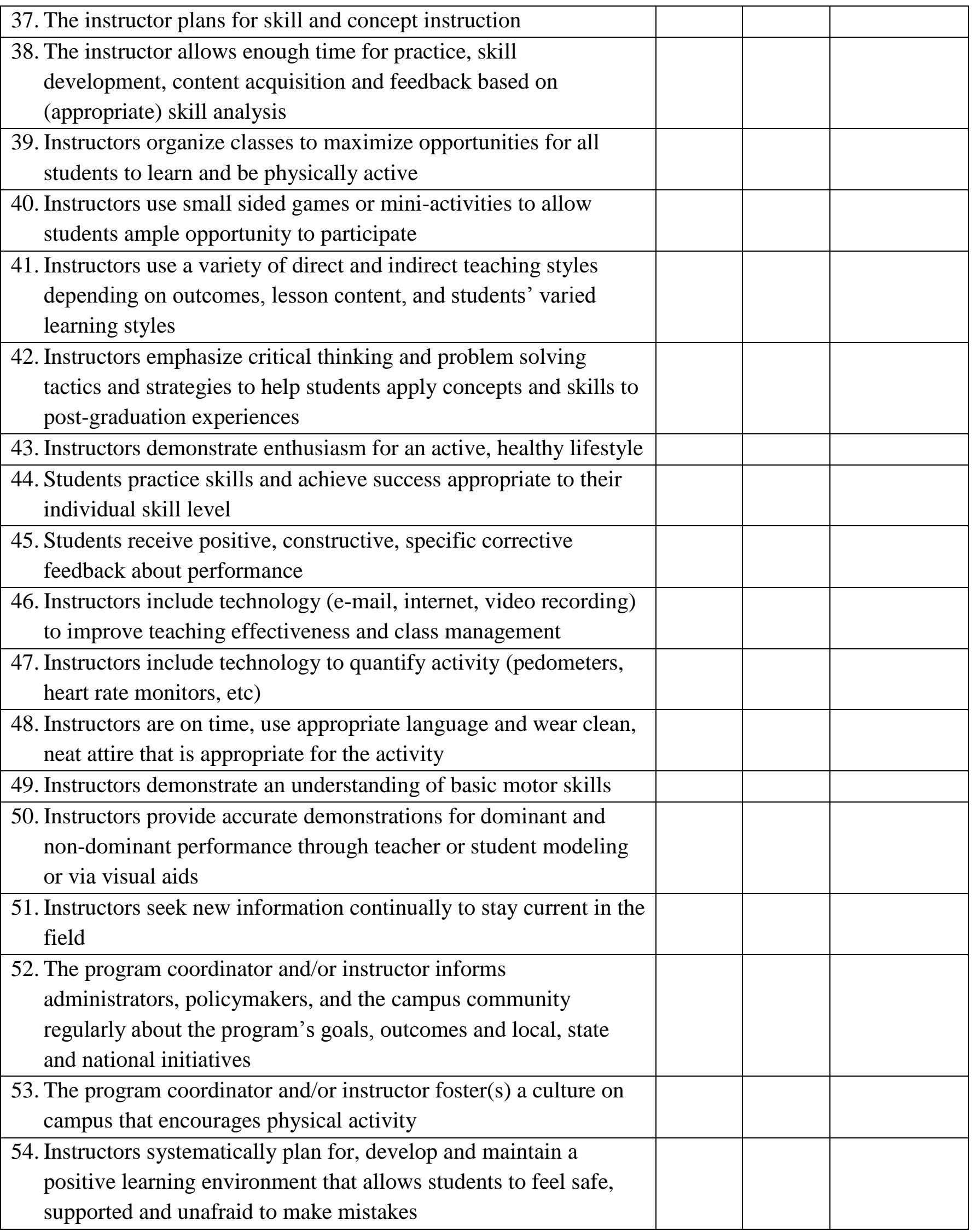




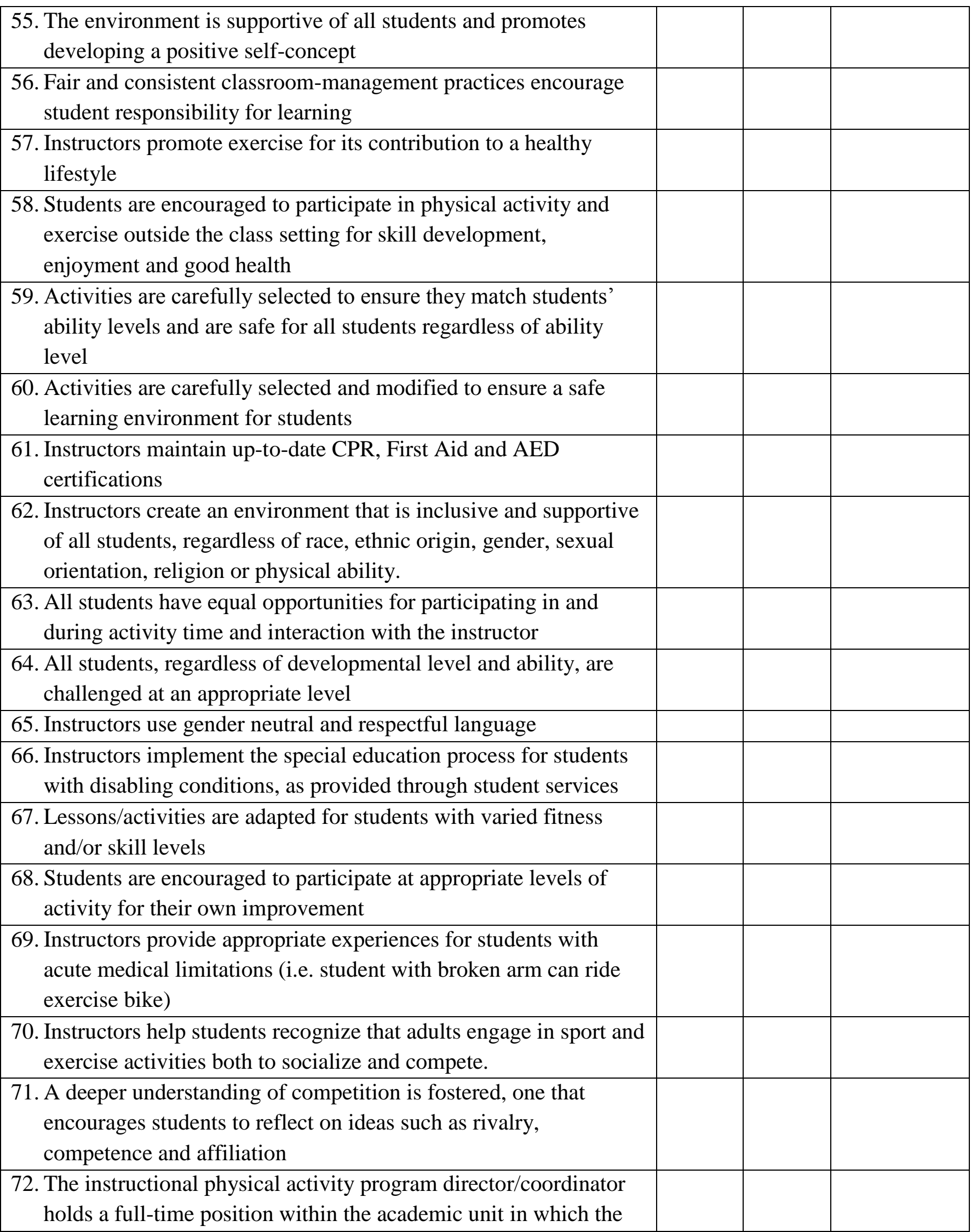




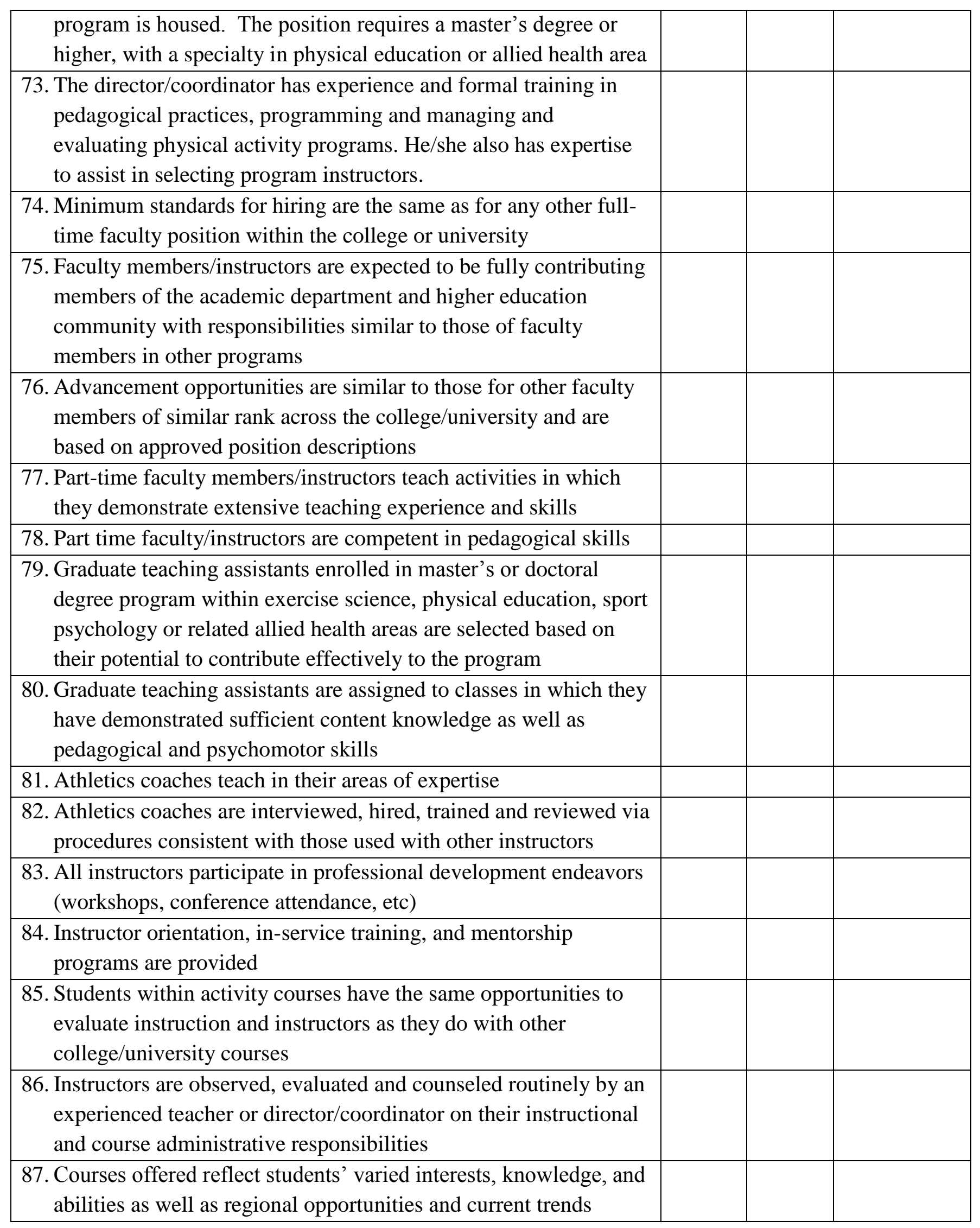




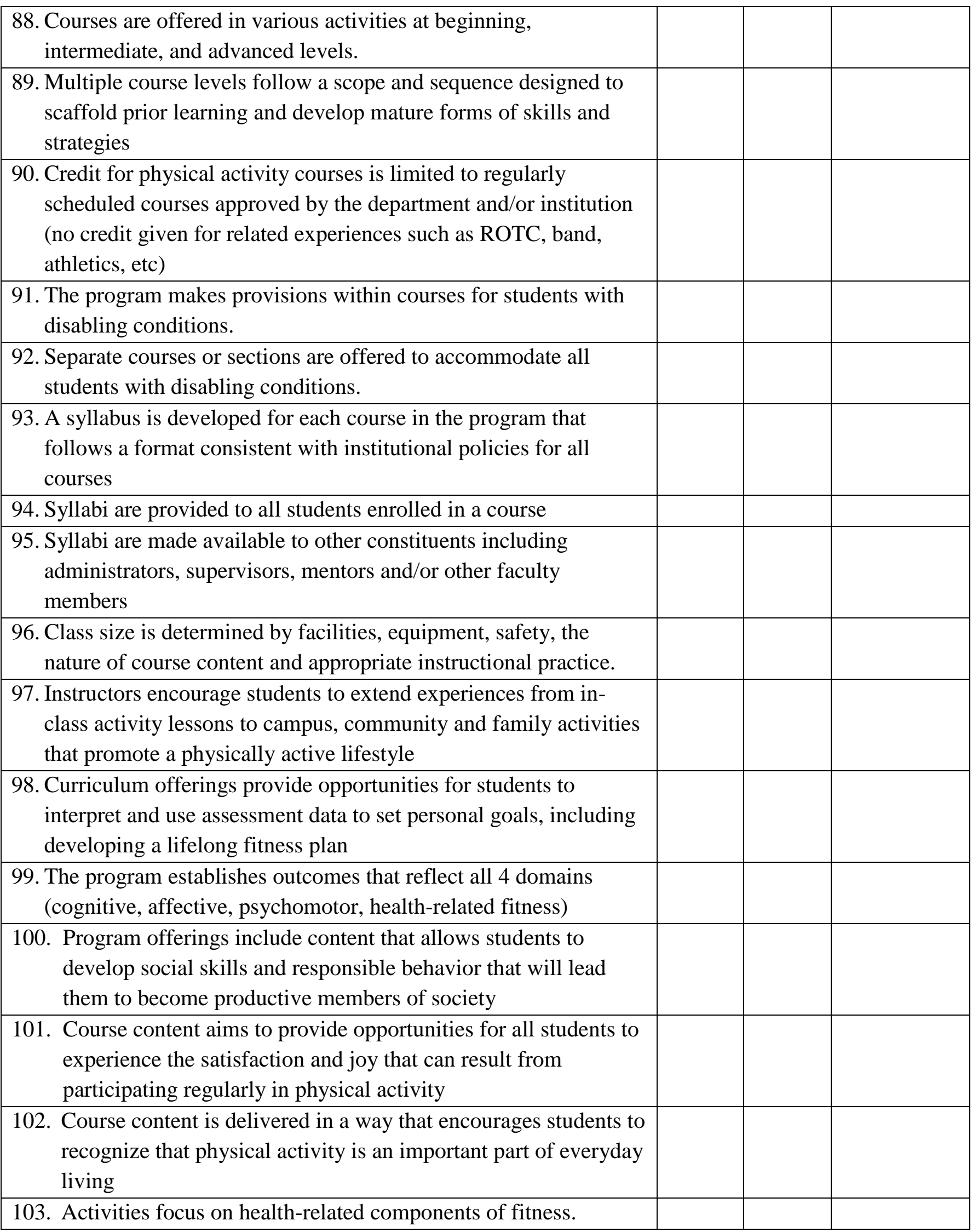


ADHERENCE TO INSTRUCTIONAL PRACTICE GUIDELINES 93

\begin{tabular}{|l|l|l|}
\hline $\begin{array}{l}\text { 104. Skill related components of fitness are emphasized in their } \\
\text { relation to skill development. }\end{array}$ & & \\
\hline $\begin{array}{l}\text { 105. Instructors within sections of the same course use common } \\
\text { course outcomes. }\end{array}$ & & \\
\hline $\begin{array}{l}\text { 106. The program has established exit outcomes which are listed on } \\
\text { all course syllabi }\end{array}$ & & \\
\hline 107. Course content is related directly to exit outcomes & & \\
\hline
\end{tabular}


ADHERENCE TO INSTRUCTIONAL PRACTICE GUIDELINES 94

\section{Appendix C: Item Selection Results}

\begin{tabular}{|c|c|c|c|c|c|c|}
\hline \multirow[b]{2}{*}{ STATEMENT } & \multicolumn{2}{|c|}{ Round 1} & \multicolumn{2}{|c|}{ Round 2} & \multicolumn{2}{|c|}{ Round 3} \\
\hline & $\operatorname{Rev} \mathbf{A}$ & $\operatorname{Rev} B$ & $\operatorname{Rev} C$ & $\operatorname{Rev} \mathbf{D}$ & $\operatorname{Rev} \mathbf{E}$ & $\operatorname{Rev} \mathbf{F}$ \\
\hline 1 & 2 & 2 & 2 & 2 & 2 & 2 \\
\hline 2 & 3 & 2 & 2 & 2 & 2 & 1 \\
\hline 3 & 3 & 2 & 2 & 2 & 2 & 1 \\
\hline 4 & 2 & 2 & 2 & 2 & 2 & 2 \\
\hline 5 & 3 & 2 & 2 & 2 & 2 & 2 \\
\hline 6 & 2 & 2 & 2 & 2 & 1 & 1 \\
\hline 7 & 1 & 2 & 2 & 2 & 2 & 2 \\
\hline 8 & 2 & 2 & 2 & 2 & 2 & 2 \\
\hline 9 & 2 & 2 & 1 & 2 & 2 & 2 \\
\hline 10 & 2 & 2 & 2 & 2 & 2 & 2 \\
\hline 11 & 2 & 2 & 2 & 2 & 2 & 2 \\
\hline 12 & 2 & 2 & 2 & 2 & 2 & 2 \\
\hline 13 & 1 & 2 & 2 & 2 & 2 & 2 \\
\hline 14 & 2 & 2 & 1 & 2 & 1 & 2 \\
\hline 15 & 2 & 2 & 2 & 2 & 2 & 2 \\
\hline 16 & 2 & 2 & 2 & 2 & 2 & 2 \\
\hline 17 & 2 & 2 & 2 & 2 & 2 & 2 \\
\hline 18 & 1 & 3 & 1 & 1 & 1 & 1 \\
\hline 19 & 1 & 1 & 1 & 1 & 1 & 1 \\
\hline 20 & 1 & 1 & 1 & 1 & 1 & 1 \\
\hline 21 & 1 & 3 & 1 & 1 & 1 & 1 \\
\hline 22 & 1 & 1 & 1 & 1 & 1 & 1 \\
\hline 23 & 1 & 1 & 1 & 1 & 1 & 1 \\
\hline 24 & 1 & 1 & 1 & 1 & 1 & 1 \\
\hline 25 & 1 & 1 & 1 & 1 & 1 & 1 \\
\hline 26 & 1 & 1 & 1 & 1 & 1 & 1 \\
\hline 27 & 1 & 1 & 1 & 1 & 1 & 1 \\
\hline 28 & 1 & 1 & 1 & 1 & 1 & 1 \\
\hline 29 & 1 & 1 & 1 & 1 & 1 & 1 \\
\hline 30 & 1 & 1 & 1 & 1 & 1 & 1 \\
\hline 31 & 2 & 2 & 2 & 2 & 1 & 1 \\
\hline 32 & 1 & 1 & 1 & 1 & 1 & 1 \\
\hline 33 & 1 & 1 & 1 & 1 & 1 & 1 \\
\hline 34 & 1 & 1 & 1 & 1 & 1 & 1 \\
\hline 35 & 1 & 1 & 1 & 1 & 1 & 1 \\
\hline 36 & 1 & 1 & 1 & 1 & 1 & 1 \\
\hline 37 & 1 & 1 & 1 & 1 & 1 & 1 \\
\hline
\end{tabular}


ADHERENCE TO INSTRUCTIONAL PRACTICE GUIDELINES 95

\begin{tabular}{|c|c|c|c|c|c|c|}
\hline 38 & 1 & 1 & 1 & 1 & 1 & 1 \\
\hline 39 & 1 & 1 & 1 & 1 & 1 & 1 \\
\hline 40 & 1 & 1 & 1 & 1 & 1 & 1 \\
\hline 41 & 1 & 1 & 1 & 1 & 1 & 1 \\
\hline 42 & 1 & 1 & 1 & 1 & 1 & 1 \\
\hline 43 & 1 & 1 & 1 & 3 & 3 & 1 \\
\hline 44 & 1 & 1 & 1 & 1 & 1 & 1 \\
\hline 45 & 1 & 1 & 1 & 1 & 1 & 1 \\
\hline 46 & 1 & 1 & 1 & 1 & 1 & 1 \\
\hline 47 & 1 & 1 & 1 & 1 & 1 & 1 \\
\hline 48 & 1 & 3 & blank & 3 & 3 & 1 \\
\hline 49 & 1 & 1 & 1 & 1 & 1 & 1 \\
\hline 50 & 1 & 1 & 1 & 1 & 1 & 1 \\
\hline 51 & 1 & 3 & 1 & 3 & 1 & 1 \\
\hline 52 & 2 & 2 & 2 & 2 & 2 & 2 \\
\hline 53 & 3 & 2 & 2 & 3 & 2 & 1 \\
\hline 54 & 2 & 1 & 1 & 1 & 1 & 1 \\
\hline 55 & 1 & 1 & 1 & 1 & 1 & 1 \\
\hline 56 & 1 & 1 & 1 & 1 & 1 & 1 \\
\hline 57 & 1 & 1 & 1 & 1 & 1 & 1 \\
\hline 58 & 1 & 1 & 1 & 3 & 1 & 1 \\
\hline 59 & 1 & 1 & 1 & 1 & 1 & 1 \\
\hline 60 & 1 & 1 & 1 & 1 & 1 & 1 \\
\hline 61 & 2 & 2 & 1 & 3 & 2 & 2 \\
\hline 62 & 1 & 1 & 1 & 3 & 1 & 1 \\
\hline 63 & 1 & 1 & 1 & 3 & 1 & 1 \\
\hline 64 & 1 & 1 & 1 & 3 & 1 & 1 \\
\hline 65 & 1 & 1 & 1 & 3 & 1 & 1 \\
\hline 66 & 1 & 1 & 1 & 3 & 1 & 1 \\
\hline 67 & 1 & 1 & 1 & 1 & 1 & 1 \\
\hline 68 & 1 & 1 & 1 & 1 & 1 & 1 \\
\hline 69 & 1 & 1 & 1 & 3 & 1 & 1 \\
\hline 70 & 1 & 1 & 1 & 3 & 1 & 1 \\
\hline 71 & 1 & 1 & 1 & 3 & 1 & 1 \\
\hline 72 & 2 & 2 & 2 & 2 & 2 & 2 \\
\hline 73 & 2 & 2 & 2 & 2 & 2 & 2 \\
\hline 74 & 3 & 2 & 2 & 2 & 2 & 2 \\
\hline 75 & 3 & 2 & 2 & 2 & 2 & 2 \\
\hline 76 & 3 & 2 & 2 & 2 & 2 & 2 \\
\hline 77 & 3 & 2 & 1 & 2 & 2 & 2 \\
\hline 78 & 3 & 2 & 1 & 1 & 2 & 2 \\
\hline
\end{tabular}


ADHERENCE TO INSTRUCTIONAL PRACTICE GUIDELINES 96

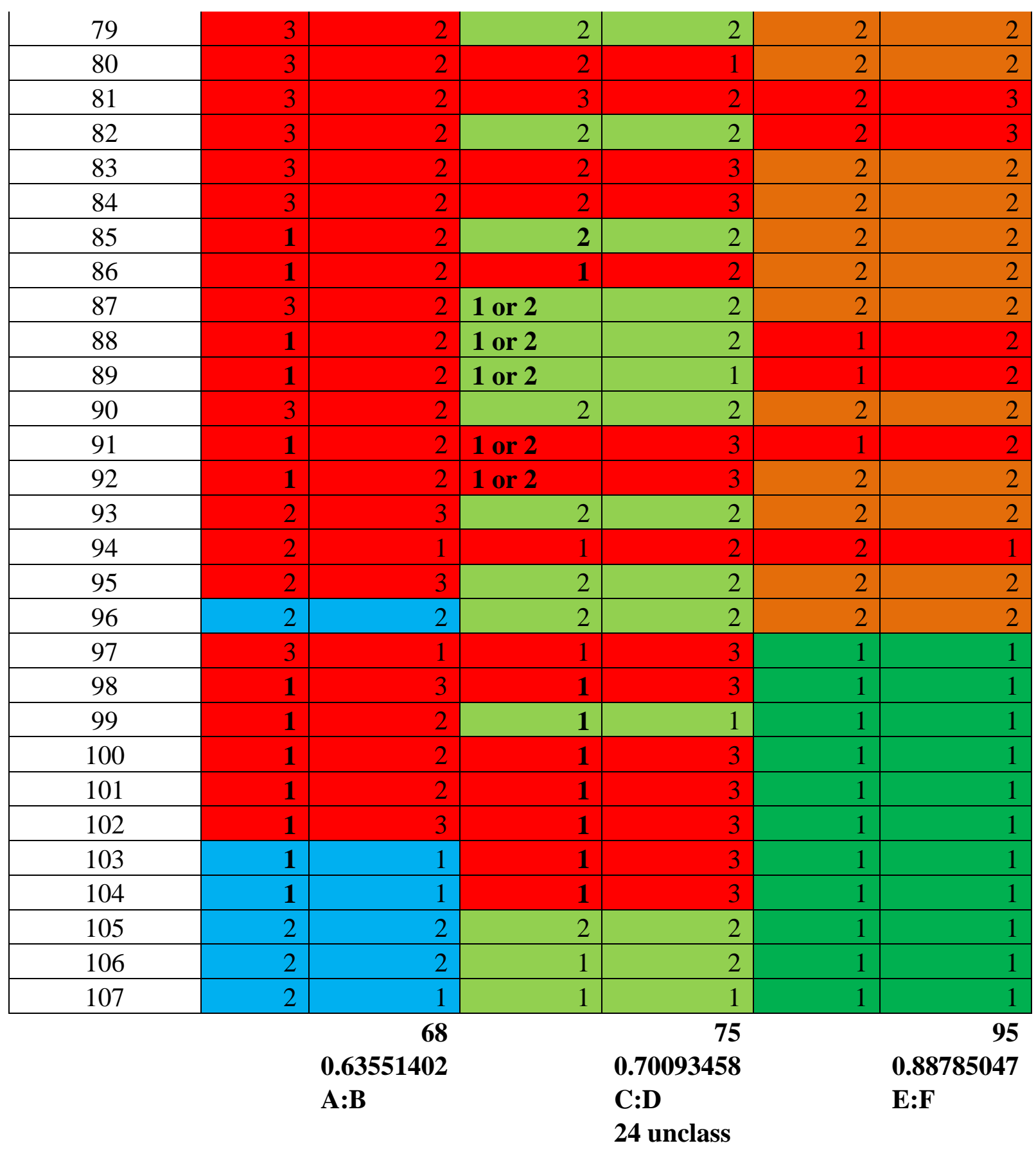




\section{Appendix D: Final Survey Instrument}

\section{Assessment of Appropriate Instructional Practice Guidelines for Higher Education Physical Activity Programs}

Survey Objective: To explore the level of adherence to the National Association for Sport and Physical Education (NASPE) Guidelines for Appropriate Instructional Practices in Higher Education Physical Activity Programs (HEPAP).

Survey completion is voluntary, with submission serving as consent to participate in the research study. All results will remain anonymous and confidential.

Thank you in advance for your time and cooperation.

Instructions: Please answer the following questions based on your knowledge and/or experience.

1. Does your institution offer a Physical Activity YES NO

Program? (may also be referred to as basic instruction program, service program, activity program, etc.)

2. Rate your familiarity with the NASPE

Very

Appropriate Instructional Practice Guidelines for

Higher Education Physical Activity Programs
Familiar

3
Not Familiar

At All

2

1

Instructions: Please reflect on your institution and program using the questions and rating scale below.

$\begin{array}{cc}\text { Fully } & \text { Not At All } \\ \text { Adhered } & \text { Adhered To }\end{array}$

\begin{tabular}{|l|l|l|l|l|l|l|}
\hline 1. $\begin{array}{l}\text { The program adheres to course policies } \\
\text { consistent with all other credit-bearing } \\
\text { coursework within the institution, including } \\
\text { those regarding instructor and student } \\
\text { responsibilities and expectations, } \\
\text { administrative roles, and standards of } \\
\text { professionalism. 1.3.1 }\end{array}$ & 5 & 3 & 2 & 1 & N/A \\
\hline $\begin{array}{l}\text { 2. } \\
\text { The program uses assessments to inform and } \\
\text { help students progress toward intended } \\
\text { outcomes. 2.1.1 }\end{array}$ & 5 & 4 & 3 & 2 & 1 & N/A \\
\hline $\begin{array}{l}\text { Formative and summative assessments } \\
\text { constitute an ongoing and integral part of the } \\
\text { learning process for all students.2.1.1 }\end{array}$ & 5 & 4 & 3 & 2 & 1 & N/A \\
\hline
\end{tabular}




\begin{tabular}{|c|c|c|c|c|c|c|}
\hline $\begin{array}{l}\text { 4. Instructors assess all domains (cognitive, } \\
\text { affective, psychomotor and health-related } \\
\text { fitness) systematically. 2.2.1 }\end{array}$ & 5 & 4 & 3 & 2 & 1 & N/A \\
\hline $\begin{array}{l}\text { 5. The program conducts individual student } \\
\text { evaluations though a variety of assessment } \\
\text { techniques. } 2.2 .2\end{array}$ & 5 & 4 & 3 & 2 & 1 & N/A \\
\hline $\begin{array}{l}\text { 6. Appropriate tests are used for students with } \\
\text { disabling conditions.2.2.3 }\end{array}$ & 5 & 4 & 3 & 2 & 1 & N/A \\
\hline $\begin{array}{l}\text { 7. Instructors are encouraged to use fitness } \\
\text { assessments as part of the ongoing process of } \\
\text { helping students understand, improve and } \\
\text { maintain their physical fitness and well- } \\
\text { being.2.3.1 }\end{array}$ & 5 & 4 & 3 & 2 & 1 & N/A \\
\hline $\begin{array}{l}\text { 8. Instructors create testing situations that are } \\
\text { private, non-threatening, educational and } \\
\text { encouraging.2.4.1 }\end{array}$ & 5 & 4 & 3 & 2 & 1 & N/A \\
\hline $\begin{array}{l}\text { 9. Instructors explain what the assessment is } \\
\text { designed to measure. 2.4.2 }\end{array}$ & 5 & 4 & 3 & 2 & 1 & N/A \\
\hline $\begin{array}{l}\text { 10. Instructors encourage students to avoid } \\
\text { comparisons and use the results as a catalyst } \\
\text { for personal improvement } 2.4 .3\end{array}$ & 5 & 4 & 3 & 2 & 1 & N/A \\
\hline $\begin{array}{l}\text { 11. Assessment results are shared privately with } \\
\text { students, with the aim toward developing } \\
\text { personal goals and strategies for maintaining } \\
\text { fitness and skill parameters. } 2.5 .1\end{array}$ & 5 & 4 & 3 & 2 & 1 & N/A \\
\hline $\begin{array}{l}\text { 12. Instructors provide students with progress } \\
\text { reports regularly using a variety of } \\
\text { continuous, formative evaluations and } \\
\text { assessments. } 2.5 .2\end{array}$ & 5 & 4 & 3 & 2 & 1 & N/A \\
\hline $\begin{array}{l}\text { 13. Grades are based on thoughtfully identified } \\
\text { criteria that are aligned with exit outcomes. } \\
2.6 .1\end{array}$ & 5 & 4 & 3 & 2 & 1 & N/A \\
\hline $\begin{array}{l}\text { 14. Students know the components of and/or } \\
\text { criteria included in their grades. } 2.6 .2\end{array}$ & 5 & 4 & 3 & 2 & 1 & N/A \\
\hline $\begin{array}{l}\text { 15. Program assessment is used to determine } \\
\text { program effectiveness, to communicate goals } \\
\text { to the student body, faculty and } \\
\text { administration, and to revise curricula. } 2.7 .1 \\
\end{array}$ & 5 & 4 & 3 & 2 & 1 & N/A \\
\hline $\begin{array}{l}\text { 16. Instructors communicate clear outcomes for } \\
\text { student learning and performance. } 3.1 .1\end{array}$ & 5 & 4 & 3 & 2 & 1 & N/A \\
\hline $\begin{array}{l}\text { 17. Instructors form pairs, groups and teams in a } \\
\text { manner that facilitates learning and preserves } \\
\text { dignity and self-respect for all students. } 3.2 .1\end{array}$ & 5 & 4 & 3 & 2 & 1 & N/A \\
\hline $\begin{array}{l}\text { 18. Class begins with an anticipatory set and } \\
\text { physical warm-up that precedes the } \\
\text { instructional focus and fitness activities. } 3.3 .1\end{array}$ & 5 & 4 & 3 & 2 & 1 & N/A \\
\hline
\end{tabular}




\begin{tabular}{|c|c|c|c|c|c|c|}
\hline $\begin{array}{l}\text { 19. Classes close with a cool-down, stretching } \\
\text { and review of the content. 3.3.1 }\end{array}$ & 5 & 4 & 3 & 2 & 1 & N/A \\
\hline $\begin{array}{l}\text { 20. Activities are designed based on a pre- } \\
\text { evaluation, outcome of the course and student } \\
\text { needs. } 3.3 .2\end{array}$ & 5 & 4 & 3 & 2 & 1 & N/A \\
\hline $\begin{array}{l}\text { 21. The instructor plans for skill and concept } \\
\text { instruction. 3.4.1 }\end{array}$ & 5 & 4 & 3 & 2 & 1 & N/A \\
\hline $\begin{array}{l}\text { 22. The instructor allows enough time for } \\
\text { practice, skill development, content } \\
\text { acquisition and feedback based on } \\
\text { (appropriate) skill analysis. } 3.4 .1\end{array}$ & 5 & 4 & 3 & 2 & 1 & N/A \\
\hline $\begin{array}{l}\text { 23. Instructors organize classes to maximize } \\
\text { opportunities for all students to learn and be } \\
\text { physically active. } 3.5 .1\end{array}$ & 5 & 4 & 3 & 2 & 1 & N/A \\
\hline $\begin{array}{l}\text { 24. Instructors use small sided games or mini- } \\
\text { activities to allow students ample opportunity } \\
\text { to participate. } 3.5 .2\end{array}$ & 5 & 4 & 3 & 2 & 1 & N/A \\
\hline $\begin{array}{l}\text { 25. Instructors use a variety of direct and indirect } \\
\text { teaching styles depending on outcomes, } \\
\text { lesson content, and students' varied learning } \\
\text { styles. 3.6.1 }\end{array}$ & 5 & 4 & 3 & 2 & 1 & N/A \\
\hline $\begin{array}{l}\text { 26. Instructors emphasize critical thinking and } \\
\text { problem solving tactics and strategies to help } \\
\text { students apply concepts and skills to post- } \\
\text { graduation experiences. } 3.6 .1\end{array}$ & 5 & 4 & 3 & 2 & 1 & N/A \\
\hline $\begin{array}{l}\text { 27. Students practice skills and achieve success } \\
\text { appropriate to their individual skill level. } \\
\text { 3.8.1 }\end{array}$ & 5 & 4 & 3 & 2 & 1 & N/A \\
\hline $\begin{array}{l}\text { 28. Students receive positive, constructive, and } \\
\text { specific corrective feedback about } \\
\text { performance. } 3.9 .1\end{array}$ & 5 & 4 & 3 & 2 & 1 & N/A \\
\hline $\begin{array}{l}\text { 29. Instructors include technology (e-mail, } \\
\text { internet, video recording) to improve teaching } \\
\text { effectiveness and class management. } 3.10 .1\end{array}$ & 5 & 4 & 3 & 2 & 1 & N/A \\
\hline $\begin{array}{l}\text { 30. Instructors include technology to quantify } \\
\text { activity (pedometers, heart rate monitors, etc). } \\
3.10 .1\end{array}$ & 5 & 4 & 3 & 2 & 1 & N/A \\
\hline $\begin{array}{l}\text { 31. Instructors demonstrate an understanding of } \\
\text { basic motor skills. } 4.2 .1\end{array}$ & 5 & 4 & 3 & 2 & 1 & N/A \\
\hline $\begin{array}{l}\text { 32. Instructors provide accurate demonstrations } \\
\text { for dominant and non-dominant performance } \\
\text { through teacher or student modeling or via } \\
\text { visual aid. 4.2.1 }\end{array}$ & 5 & 4 & 3 & 2 & 1 & N/A \\
\hline $\begin{array}{l}\text { 33. Instructors continually seek new information } \\
\text { to stay current in the field. } 4.3 .1\end{array}$ & 5 & 4 & 3 & 2 & 1 & N/A \\
\hline 34. Instructors systematically plan for, develop, & 5 & 4 & 3 & 2 & 1 & N/A \\
\hline
\end{tabular}




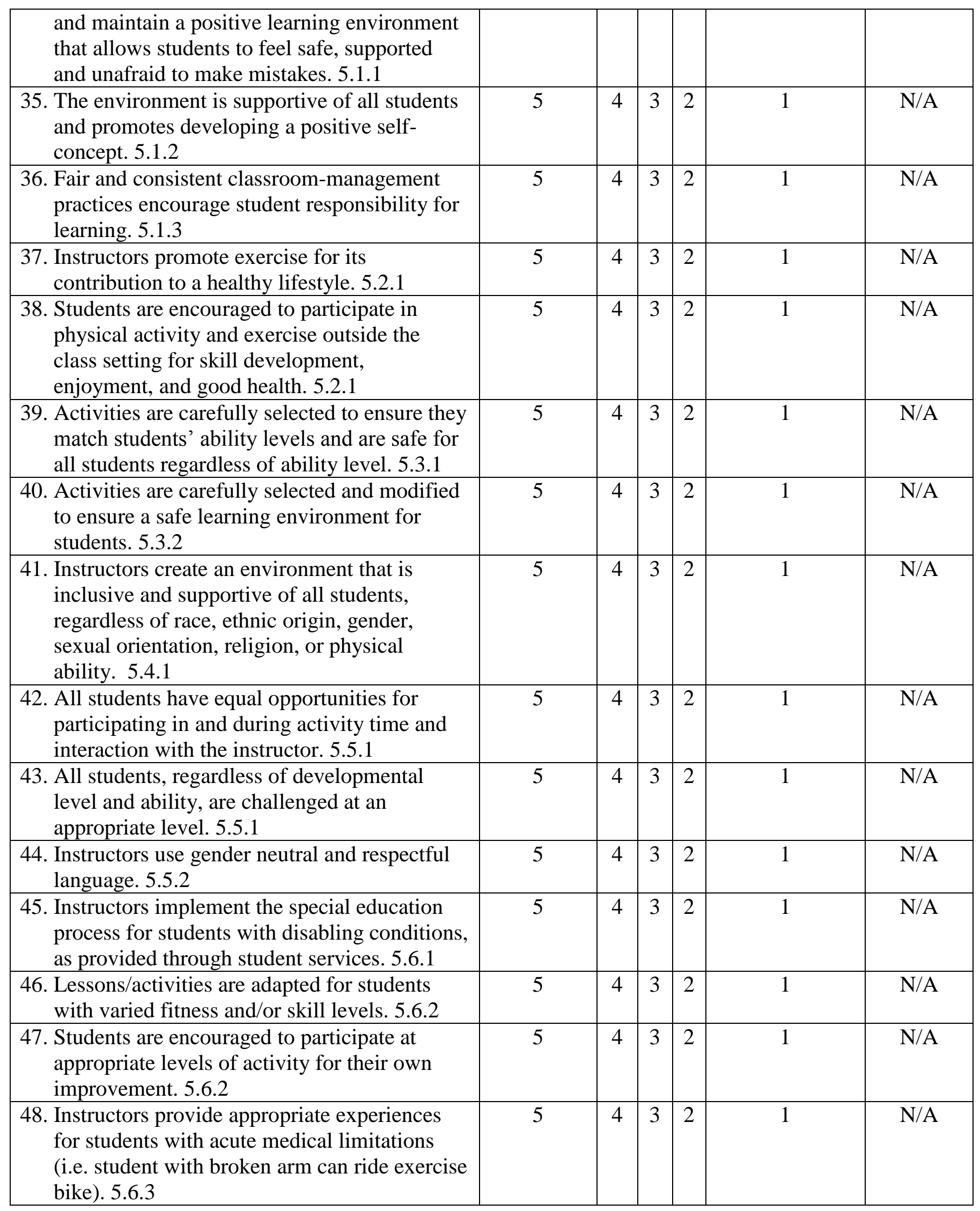




\begin{tabular}{|c|c|c|c|c|c|c|}
\hline $\begin{array}{l}\text { 49. Instructors help students recognize that adults } \\
\text { engage in sport and exercise activities both to } \\
\text { socialize and compete. } 5.7 .1\end{array}$ & 5 & 4 & 3 & 2 & 1 & $\mathrm{~N} / \mathrm{A}$ \\
\hline $\begin{array}{l}\text { 50. A deeper understanding of competition is } \\
\text { fostered, one that encourages students to } \\
\text { reflect on ideas such as rivalry, competence, } \\
\text { and affiliation. 5.7.1 }\end{array}$ & 5 & 4 & 3 & 2 & 1 & N/A \\
\hline $\begin{array}{l}\text { 51. Instructors encourage students to extend } \\
\text { experiences from in-class activity lessons to } \\
\text { campus, community, and family activities that } \\
\text { promote a physically active lifestyle.7.6.1 }\end{array}$ & 5 & 4 & 3 & 2 & 1 & N/A \\
\hline $\begin{array}{l}\text { 52. Curriculum offerings provide opportunities } \\
\text { for students to interpret and use assessment } \\
\text { data to set personal goals, including } \\
\text { developing a lifelong fitness plan. 7.7.1 }\end{array}$ & 5 & 4 & 3 & 2 & 1 & N/A \\
\hline $\begin{array}{l}\text { 53. The program establishes outcomes that reflect } \\
4 \text { domains (cognitive, affective, psychomotor, } \\
\text { health-related fitness). 7.8.1 }\end{array}$ & 5 & 4 & 3 & 2 & 1 & $\mathrm{~N} / \mathrm{A}$ \\
\hline $\begin{array}{l}\text { 54. Program offerings include content that allows } \\
\text { students to develop social skills and } \\
\text { responsible behavior that will lead them to } \\
\text { become productive members of society. } 7.8 .2\end{array}$ & 5 & 4 & 3 & 2 & 1 & $\mathrm{~N} / \mathrm{A}$ \\
\hline $\begin{array}{l}\text { 55. Course content aims to provide opportunities } \\
\text { for all students to experience the satisfaction } \\
\text { and joy that can result from participating } \\
\text { regularly in physical activity. } 7.8 .3\end{array}$ & 5 & 4 & 3 & 2 & 1 & N/A \\
\hline $\begin{array}{l}\text { 56. Course content is delivered in a way that } \\
\text { encourages students to recognize that physical } \\
\text { activity is an important part of everyday } \\
\text { living. } 7.8 .4\end{array}$ & 5 & 4 & 3 & 2 & 1 & $\mathrm{~N} / \mathrm{A}$ \\
\hline $\begin{array}{l}\text { 57. Activities focus on health-related components } \\
\text { of fitness. } 7.8 .5\end{array}$ & 5 & 4 & 3 & 2 & 1 & N/A \\
\hline $\begin{array}{l}\text { 58. Skill related components of fitness are } \\
\text { emphasized in their relation to skill } \\
\text { development. } 7.8 .5\end{array}$ & 5 & 4 & 3 & 2 & 1 & N/A \\
\hline $\begin{array}{l}\text { 59. Instructors within sections of the same course } \\
\text { use common course outcomes. 7.8.6 }\end{array}$ & 5 & 4 & 3 & 2 & 1 & $\mathrm{~N} / \mathrm{A}$ \\
\hline $\begin{array}{l}\text { 60. The program has established exit outcomes } \\
\text { which are listed on all course syllabi. 7.9.1 }\end{array}$ & 5 & 4 & 3 & 2 & 1 & $\mathrm{~N} / \mathrm{A}$ \\
\hline $\begin{array}{l}\text { 61. Course content is related directly to exit } \\
\text { outcomes. 7.9.1 }\end{array}$ & 5 & 4 & 3 & 2 & 1 & N/A \\
\hline
\end{tabular}

\section{Demographic Information.}


Please answer the following questions about your institution.

a. The overall student enrollment at your institution is
a) $500-1000$
b) $1001-2500$
c) $2,501-5,000$
d) $5,001-10,000$
e) $10,001-20,000$
f) $>20,000$
g) I don't know

b. Your institutional affiliation is
a) Private
b) Public

c. Is physical education required for graduation? Yes/no (circle one)

d. The number of full time faculty who teach in your HEPAP is:

e. The number of part-time faculty who teach in your HEPAP is:

f. The number of graduate teaching assistants who teach in your HEPAP is: 


\section{Appendix E: IRB Cover Letter}

July 25, 2012

\section{Dear Participant,}

This letter is a request for you to take part in a research project to assess adherence to National Association for Sport and Physical Education (NASPE) Guidelines for Appropriate Instructional Practices in Higher Education Physical Activity Programs (HEPAPs). This project is being conducted by Drue Stapleton in the College of Physical Activity and Sports Sciences at WVU with supervision of Dr. Sean Bulger, an assistant professor in the College of Physical Activity and Sports Sciences, for a doctoral dissertation. Your participation in this project is greatly appreciated and will take approximately 20 minutes to complete the questionnaire. If there is an individual within your department who is better suited to complete this survey (i.e. HEPAP Coordinator), please forward this information.

Your involvement in this project will be kept as confidential as legally possible. All data will be reported in the aggregate. You must be 18 years of age or older to participate. I will not ask any information that should lead back to your identity as a participant. Your participation is completely voluntary. You may skip any question that you do not wish to answer and you may discontinue at any time. West Virginia University's Institutional Review Board acknowledgement of this project is on file.

I hope that you will participate in this research project, as it could be beneficial in determining adherence to NASPE guidelines and may provide valuable information about HEPAPs. Thank you very much for your time. Should you have any questions about this letter or the research project, please feel free to contact Drue Stapleton at (304) 293-0866 or by e-mail at drue.stapleton@mail.wvu.edu.

Thank you for your time and help with this project.

Sincerely,

Drue Stapleton, MEd, ATC, CSCS

Sean Bulger, EdD, CSCS

\section{Directions:}

This 61-item survey consists of Likert-type scale rating items and demographic information. The survey requires approximately 20 minutes of your time. Please click on the link below to begin the survey. The link will open the survey in a new Internet window. Upon completing the survey, please click on the icon "Done" (located at the bottom of the survey) to submit your responses. Thank you for participating. (LINK TO SURVEY) 


\section{Appendix F: Final Instrument Mapping}

Mapping Guidelines to Final Instrument

\begin{tabular}{|c|c|c|}
\hline $\begin{array}{l}\text { Instrument } \\
\text { Item }\end{array}$ & $\begin{array}{l}\text { Associated } \\
\text { Guideline }\end{array}$ & Subcategory \\
\hline 1 & 1.3 .1 & $\begin{array}{l}1.0 \\
\text { ADMINISTRATION/SUPPORT }\end{array}$ \\
\hline 2 & 2.1 .1 & 2.0: ASSESSMENT \\
\hline 3 & 2.1 .1 & \\
\hline 4 & 2.2 .1 & \\
\hline 5 & 2.2 .2 & \\
\hline 6 & 2.2 .3 & \\
\hline 7 & 2.3 .1 & \\
\hline 8 & 2.4 .1 & \\
\hline 9 & 2.4 .2 & \\
\hline 10 & 2.4 .3 & \\
\hline 11 & 2.5 .1 & \\
\hline 12 & 2.5 .2 & \\
\hline 13 & 2.6 .1 & \\
\hline 14 & 2.6 .2 & \\
\hline 15 & 2.7 .1 & \\
\hline 16 & 3.1 .1 & $\begin{array}{l}\text { 3.0 INSTRUCTION } \\
\text { STRATEGIES }\end{array}$ \\
\hline 17 & 3.2 .1 & \\
\hline 18 & 3.3 .1 & \\
\hline 19 & 3.3 .1 & \\
\hline 20 & 3.3 .2 & \\
\hline 21 & 3.4 .1 & \\
\hline 22 & 3.4 .1 & \\
\hline 23 & 3.5 .1 & \\
\hline 24 & 3.5 .2 & \\
\hline 25 & 3.6 .1 & \\
\hline 26 & 3.6 .1 & \\
\hline 27 & 3.8 .1 & \\
\hline 28 & 3.9 .1 & \\
\hline 29 & 3.10 .1 & \\
\hline 30 & 3.10 .1 & \\
\hline 31 & 4.2 .1 & 4.0: PROFESSIONALISM \\
\hline 32 & 4.2 .1 & \\
\hline 33 & 4.3 .1 & \\
\hline 34 & 5.1 .1 & 5.0: LEARNING \\
\hline
\end{tabular}




\begin{tabular}{|l|l|l|}
\hline & & ENVIRONMENT \\
\hline 35 & 5.1 .2 & \\
\hline 36 & 5.1 .3 & \\
\hline 37 & 5.2 .1 & \\
\hline 38 & 5.2 .1 & \\
\hline 39 & 5.3 .1 & \\
\hline 40 & 5.3 .2 & \\
\hline 41 & 5.4 .1 & \\
\hline 42 & 5.5 .1 & \\
\hline 43 & 5.5 .1 & \\
\hline 44 & 5.5 .2 & \\
\hline 45 & 5.6 .1 & \\
\hline 46 & 5.6 .2 & \\
\hline 47 & 5.6 .2 & $\mathbf{7 . 0}$ CURRICULUM \\
\hline 48 & 5.6 .3 & \\
\hline 49 & 5.7 .1 & \\
\hline 50 & 5.7 .1 & \\
\hline 51 & 7.6 .1 & \\
\hline 52 & 7.7 .1 & \\
\hline 53 & 7.8 .1 & \\
\hline 54 & 7.8 .2 & \\
\hline 55 & 7.8 .3 & \\
\hline 56 & 7.8 .4 & \\
\hline 57 & 7.8 .5 & \\
\hline 58 & 7.8 .5 & \\
\hline 59 & 7.8 .6 & \\
\hline 60 & 7.9 .1 & \\
\hline 61 & 7.9 .1 & \\
\hline & & \\
\hline
\end{tabular}

6.0 PROGRAM STAFFING

no guidelines included 


\section{Appendix G: Familiarity and Institutional Variables}

\section{Crosstabs}

Notes

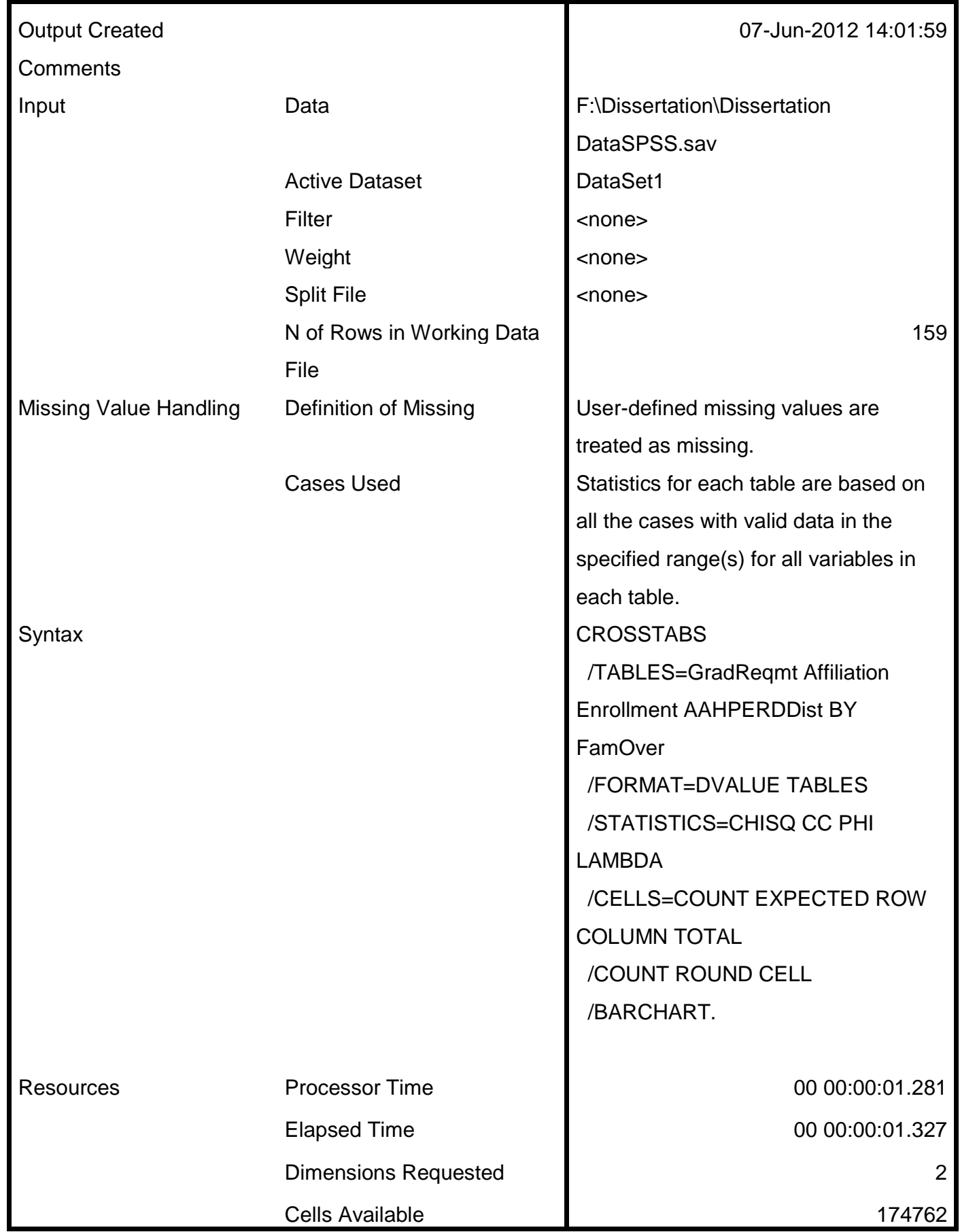

[DataSet1] F:IDissertation\Dissertation DataSPSS.sav 
Case Processing Summary

\begin{tabular}{|c|c|c|c|c|c|c|}
\hline & \multicolumn{6}{|c|}{ Cases } \\
\hline & \multicolumn{2}{|c|}{ Valid } & \multicolumn{2}{|c|}{ Missing } & \multicolumn{2}{|c|}{ Total } \\
\hline & $\mathrm{N}$ & Percent & $\mathrm{N}$ & Percent & $\mathrm{N}$ & Percent \\
\hline $\begin{array}{l}\text { PE Graduation Requirement } \\
\text { * Familiarity with Guidelines }\end{array}$ & 87 & $54.7 \%$ & 72 & $45.3 \%$ & 159 & $100.0 \%$ \\
\hline $\begin{array}{l}\text { Affiliation * Familiarity with } \\
\text { Guidelines }\end{array}$ & 89 & $56.0 \%$ & 70 & $44.0 \%$ & 159 & $100.0 \%$ \\
\hline $\begin{array}{l}\text { Enrollment * Familiarity with } \\
\text { Guidelines }\end{array}$ & 89 & $56.0 \%$ & 70 & $44.0 \%$ & 159 & $100.0 \%$ \\
\hline $\begin{array}{l}\text { Location(AAHPERD District) } \\
{ }^{*} \text { Familiarity with Guidelines }\end{array}$ & 89 & $56.0 \%$ & 70 & $44.0 \%$ & 159 & $100.0 \%$ \\
\hline
\end{tabular}

\section{PE Graduation Requirement * Familiarity with Guidelines}

\begin{tabular}{|c|c|c|c|c|c|c|}
\hline \multicolumn{7}{|c|}{ Crosstab } \\
\hline & & & \multicolumn{3}{|c|}{ Familiarity with Guidelines } & \multirow[b]{2}{*}{ Total } \\
\hline & & & $\begin{array}{c}\text { NOT AT ALL } \\
\text { AWARE }\end{array}$ & $\begin{array}{c}\text { SOMEWHAT } \\
\text { AWARE }\end{array}$ & $\begin{array}{l}\text { FULLY } \\
\text { AWARE } \\
\end{array}$ & \\
\hline \multirow{14}{*}{$\begin{array}{l}\text { PE Graduation } \\
\text { Requirement }\end{array}$} & NO & Count & 1 & 15 & 18 & 34 \\
\hline & & Expected Count & 1.2 & 13.7 & 19.1 & 34.0 \\
\hline & & $\%$ within PE Graduation & $2.9 \%$ & $44.1 \%$ & $52.9 \%$ & $100.0 \%$ \\
\hline & & Requirement & & & & \\
\hline & & $\%$ within Familiarity with & $33.3 \%$ & $42.9 \%$ & $36.7 \%$ & $39.1 \%$ \\
\hline & & Guidelines & & & & \\
\hline & & $\%$ of Total & $1.1 \%$ & $17.2 \%$ & $20.7 \%$ & $39.1 \%$ \\
\hline & YES & Count & 2 & 20 & 31 & 53 \\
\hline & & Expected Count & 1.8 & 21.3 & 29.9 & 53.0 \\
\hline & & $\%$ within PE Graduation & $3.8 \%$ & $37.7 \%$ & $58.5 \%$ & $100.0 \%$ \\
\hline & & Requirement & & & & \\
\hline & & $\%$ within Familiarity with & $66.7 \%$ & $57.1 \%$ & $63.3 \%$ & $60.9 \%$ \\
\hline & & Guidelines & & & & \\
\hline & & $\%$ of Total & $2.3 \%$ & $23.0 \%$ & $35.6 \%$ & $60.9 \%$ \\
\hline \multirow[t]{4}{*}{ Total } & & Count & 3 & 35 & 49 & 87 \\
\hline & & Expected Count & 3.0 & 35.0 & 49.0 & 87.0 \\
\hline & & $\%$ within PE Graduation & $3.4 \%$ & $40.2 \%$ & $56.3 \%$ & $100.0 \%$ \\
\hline & & Requirement & & & & \\
\hline
\end{tabular}


ADHERENCE TO INSTRUCTIONAL PRACTICE GUIDELINES 108

\begin{tabular}{|l|r|r|r|r|}
\hline $\begin{array}{l}\text { \% within Familiarity with } \\
\text { Guidelines } \\
\text { \% of Total }\end{array}$ & $100.0 \%$ & $100.0 \%$ & $100.0 \%$ & $100.0 \%$ \\
\hline
\end{tabular}

\section{Chi-Square Tests}

\begin{tabular}{|l|r|r|r|}
\hline & \multicolumn{1}{|c|}{ Value } & df & \multicolumn{1}{c|}{$\begin{array}{c}\text { Asymp. Sig. (2- } \\
\text { sided) }\end{array}$} \\
\hline Pearson Chi-Square & $.365^{\mathrm{a}}$ & 2 & .833 \\
Likelihood Ratio & .364 & 2 & .834 \\
Linear-by-Linear Association & .143 & 1 & .705 \\
N of Valid Cases & 87 & & \\
\hline
\end{tabular}

a. 2 cells $(33.3 \%)$ have expected count less than 5 . The minimum expected count is 1.17 .

Directional Measures

\begin{tabular}{|c|c|c|c|c|c|c|}
\hline & & & Value & $\begin{array}{c}\text { Asymp. Std. } \\
\text { Error }^{\mathrm{a}}\end{array}$ & Approx. T & $\begin{array}{l}\text { Approx. } \\
\text { Sig. }\end{array}$ \\
\hline \multirow[t]{9}{*}{ Nominal by Nominal } & Lambda & Symmetric & .000 & .000 &.$^{b}$ & b \\
\hline & & PE Graduation & .000 & .000 & b &.$^{b}$ \\
\hline & & Requirement Dependent & & & & \\
\hline & & Familiarity with & .000 & .000 &.$^{\mathrm{b}}$ &.$^{b}$ \\
\hline & & Guidelines Dependent & & & & \\
\hline & Goodman and Kruskal & PE Graduation & .004 & .014 & & $.835^{\mathrm{c}}$ \\
\hline & tau & Requirement Dependent & & & & \\
\hline & & Familiarity with & .003 & .012 & & $.752^{\mathrm{c}}$ \\
\hline & & Guidelines Dependent & & & & \\
\hline
\end{tabular}

a. Not assuming the null hypothesis.

b. Cannot be computed because the asymptotic standard error equals zero.

C. Based on chi-square approximation 
Symmetric Measures

\begin{tabular}{|ll|r|r|}
\hline & & Value & Approx. Sig. \\
\hline Nominal by Nominal & Phi & .065 & .833 \\
& Cramer's V & .065 & .833 \\
& Contingency Coefficient & .065 & .833 \\
N of Valid Cases & & 87 & \\
\hline
\end{tabular}

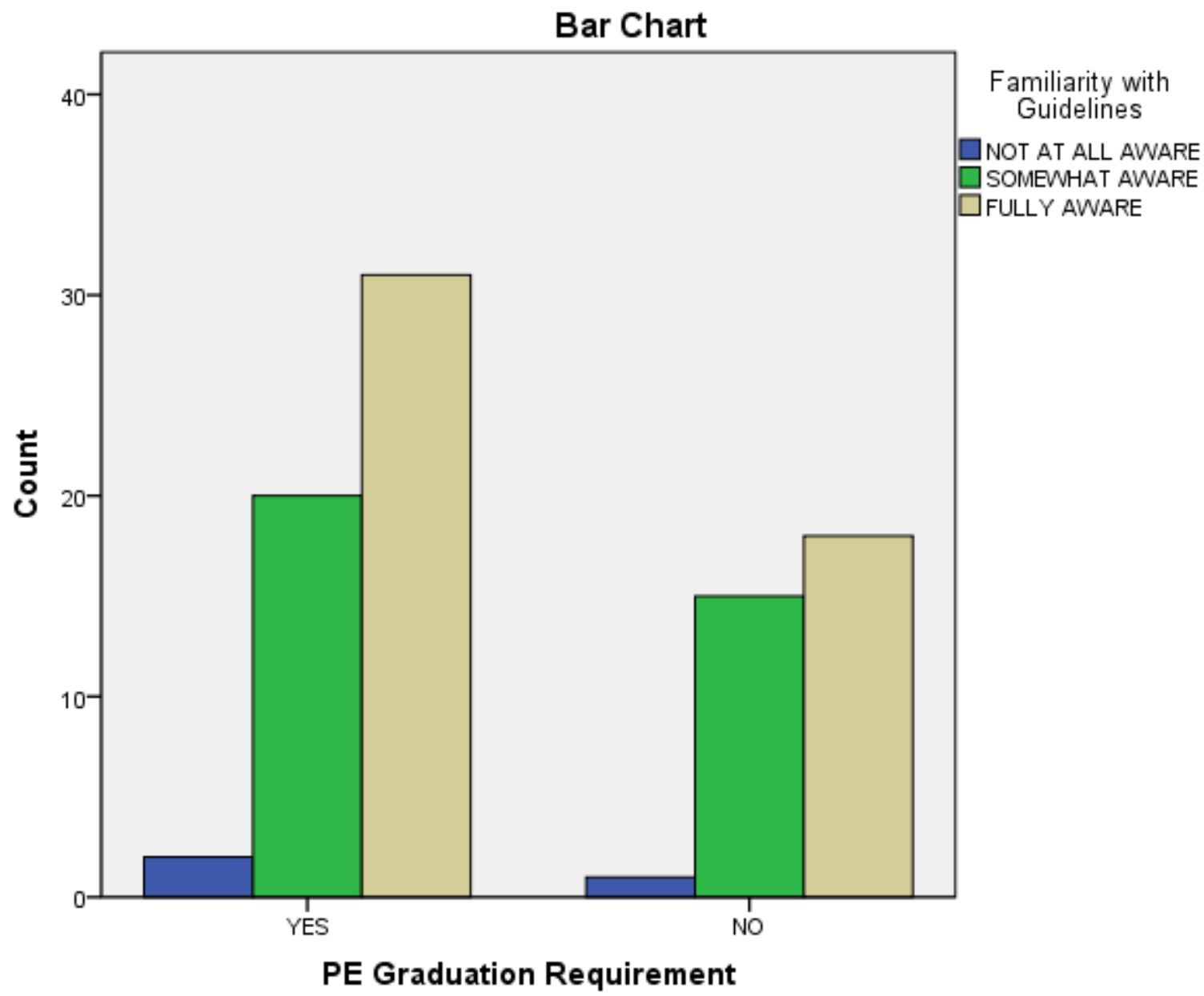


Affiliation * Familiarity with Guidelines

\begin{tabular}{|c|c|c|c|c|c|c|}
\hline \multicolumn{7}{|c|}{ Crosstab } \\
\hline & & & \multicolumn{3}{|c|}{ Familiarity with Guidelines } & \multirow[b]{2}{*}{ Total } \\
\hline & & & $\begin{array}{c}\text { NOT AT ALL } \\
\text { AWARE }\end{array}$ & $\begin{array}{c}\text { SOMEWHAT } \\
\text { AWARE }\end{array}$ & $\begin{array}{l}\text { FULLY } \\
\text { AWARE }\end{array}$ & \\
\hline \multirow[t]{12}{*}{ Affiliation } & PRIVATE & Count & 0 & 18 & 23 & 41 \\
\hline & & Expected Count & 1.4 & 17.0 & 22.6 & 41.0 \\
\hline & & $\%$ within Affiliation & $.0 \%$ & $43.9 \%$ & $56.1 \%$ & $100.0 \%$ \\
\hline & & $\%$ within Familiarity with & $.0 \%$ & $48.6 \%$ & $46.9 \%$ & $46.1 \%$ \\
\hline & & Guidelines & & & & \\
\hline & & $\%$ of Total & $.0 \%$ & $20.2 \%$ & $25.8 \%$ & $46.1 \%$ \\
\hline & PUBLIC & Count & 3 & 19 & 26 & 48 \\
\hline & & Expected Count & 1.6 & 20.0 & 26.4 & 48.0 \\
\hline & & $\%$ within Affiliation & $6.3 \%$ & $39.6 \%$ & $54.2 \%$ & $100.0 \%$ \\
\hline & & $\%$ within Familiarity with & $100.0 \%$ & $51.4 \%$ & $53.1 \%$ & $53.9 \%$ \\
\hline & & Guidelines & & & & \\
\hline & & $\%$ of Total & $3.4 \%$ & $21.3 \%$ & $29.2 \%$ & $53.9 \%$ \\
\hline \multirow[t]{6}{*}{ Total } & & Count & 3 & 37 & 49 & 89 \\
\hline & & Expected Count & 3.0 & 37.0 & 49.0 & 89.0 \\
\hline & & $\%$ within Affiliation & $3.4 \%$ & $41.6 \%$ & $55.1 \%$ & $100.0 \%$ \\
\hline & & $\%$ within Familiarity with & $100.0 \%$ & $100.0 \%$ & $100.0 \%$ & $100.0 \%$ \\
\hline & & Guidelines & & & & \\
\hline & & $\%$ of Total & $3.4 \%$ & $41.6 \%$ & $55.1 \%$ & $100.0 \%$ \\
\hline
\end{tabular}

Chi-Square Tests

\begin{tabular}{|c|c|c|c|}
\hline & Value & $\mathrm{df}$ & $\begin{array}{c}\text { Asymp. Sig. (2- } \\
\text { sided) }\end{array}$ \\
\hline Pearson Chi-Square & $2.677^{\mathrm{a}}$ & 2 & .262 \\
\hline Likelihood Ratio & 3.819 & 2 & .148 \\
\hline Linear-by-Linear Association & .461 & 1 & 497 \\
\hline $\mathrm{N}$ of Valid Cases & 89 & & \\
\hline
\end{tabular}

a. 2 cells $(33.3 \%)$ have expected count less than 5 . The minimum expected count is 1.38 . 
ADHERENCE TO INSTRUCTIONAL PRACTICE GUIDELINES 111

Directional Measures

\begin{tabular}{|c|c|c|c|c|c|c|}
\hline & & & Value & $\begin{array}{c}\text { Asymp. Std. } \\
\text { Error }^{\mathrm{a}}\end{array}$ & Approx. T & $\begin{array}{l}\text { Approx. } \\
\text { Sig. }\end{array}$ \\
\hline \multirow[t]{7}{*}{ Nominal by Nominal } & Lambda & Symmetric & .000 & .000 &. & b \\
\hline & & Affiliation Dependent & .000 & .000 &. & $b^{b}$ \\
\hline & & Familiarity with & .000 & .000 &. & b \\
\hline & & Guidelines Dependent & & & & \\
\hline & \multirow{3}{*}{$\begin{array}{l}\text { Goodman and Kruskal } \\
\text { tau }\end{array}$} & Affiliation Dependent & .030 & .007 & & $.266^{\mathrm{c}}$ \\
\hline & & Familiarity with & .003 & .004 & & $.773^{\mathrm{c}}$ \\
\hline & & Guidelines Dependent & & & & \\
\hline
\end{tabular}

a. Not assuming the null hypothesis.

b. Cannot be computed because the asymptotic standard error equals zero.

c. Based on chi-square approximation

\section{Symmetric Measures}

\begin{tabular}{|ll|r|r|}
\hline & & \multicolumn{1}{|c|}{ Value } & Approx. Sig. \\
\hline Nominal by Nominal & Phi & .173 & .262 \\
& Cramer's V & .173 & .262 \\
& Contingency Coefficient & .171 & .262 \\
N of Valid Cases & & 89 & \\
\hline
\end{tabular}




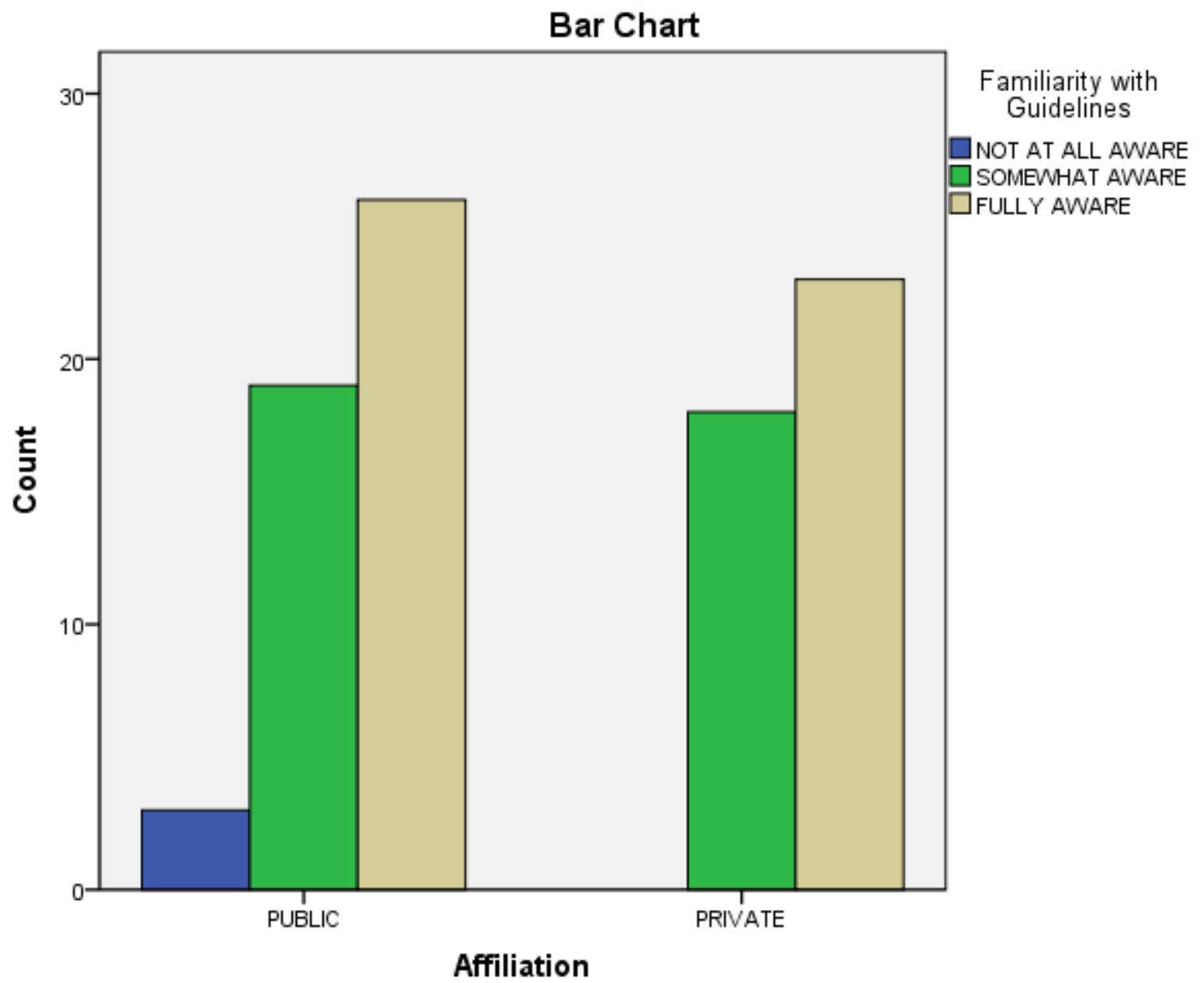

\section{Enrollment * Familiarity with Guidelines}

\begin{tabular}{|ll|r|r|r|r|}
\hline \multicolumn{1}{|c|}{ Crosstab } \\
\cline { 2 - 5 } & $\begin{array}{c}\text { NOT AT ALL } \\
\text { AWARE }\end{array}$ & $\begin{array}{c}\text { SOMEWHAT } \\
\text { AWARE }\end{array}$ & $\begin{array}{r}\text { FULLY } \\
\text { AWARE }\end{array}$ & Total \\
\hline Enrollment Large $(>10,000)$ & Count & 1 & 11 & 13 & 25 \\
& Expected Count & .8 & 10.4 & 13.8 & 25.0 \\
\% within Enrollment & $4.0 \%$ & $44.0 \%$ & $52.0 \%$ & $100.0 \%$ \\
\% within Familiarity & $33.3 \%$ & $29.7 \%$ & $26.5 \%$ & $28.1 \%$ \\
with Guidelines & & $1.1 \%$ & $12.4 \%$ & $14.6 \%$ & $28.1 \%$ \\
\hline
\end{tabular}


ADHERENCE TO INSTRUCTIONAL PRACTICE GUIDELINES 113

\begin{tabular}{|c|c|c|c|c|c|c|}
\hline & $\begin{array}{l}\text { Medium (2501- } \\
10000)\end{array}$ & $\begin{array}{l}\text { Count } \\
\text { Expected Count } \\
\% \text { within Enrollment } \\
\% \text { within Familiarity } \\
\text { with Guidelines } \\
\% \text { of Total }\end{array}$ & $\begin{array}{r}2 \\
.9 \\
7.7 \% \\
66.7 \% \\
2.2 \% \\
\end{array}$ & $\begin{array}{r}9 \\
10.8 \\
34.6 \% \\
24.3 \% \\
10.1 \% \\
\end{array}$ & $\begin{array}{r}15 \\
14.3 \\
57.7 \% \\
30.6 \% \\
16.9 \% \\
\end{array}$ & $\begin{array}{r}26 \\
26.0 \\
100.0 \% \\
29.2 \% \\
29.2 \% \\
\end{array}$ \\
\hline & Small (500-2500) & $\begin{array}{l}\text { Count } \\
\text { Expected Count } \\
\% \text { within Enrollment } \\
\% \text { within Familiarity } \\
\text { with Guidelines } \\
\% \text { of Total }\end{array}$ & $\begin{array}{r}0 \\
1.3 \\
.0 \% \\
.0 \% \\
.0 \%\end{array}$ & $\begin{array}{r}17 \\
15.8 \\
44.7 \% \\
45.9 \% \\
19.1 \%\end{array}$ & $\begin{array}{r}21 \\
20.9 \\
55.3 \% \\
42.9 \% \\
23.6 \%\end{array}$ & $\begin{array}{r}38 \\
38.0 \\
100.0 \% \\
42.7 \% \\
42.7 \%\end{array}$ \\
\hline Total & & $\begin{array}{l}\text { Count } \\
\text { Expected Count } \\
\% \text { within Enrollment } \\
\% \text { within Familiarity } \\
\text { with Guidelines } \\
\% \text { of Total }\end{array}$ & $\begin{array}{r}3 \\
3.0 \\
3.4 \% \\
100.0 \% \\
3.4 \%\end{array}$ & $\begin{array}{r}37 \\
37.0 \\
41.6 \% \\
100.0 \% \\
41.6 \%\end{array}$ & $\begin{array}{r}49 \\
49.0 \\
55.1 \% \\
100.0 \% \\
\\
55.1 \% \\
\end{array}$ & $\begin{array}{r}89 \\
89.0 \\
100.0 \% \\
100.0 \% \\
100.0 \% \\
\end{array}$ \\
\hline
\end{tabular}

\section{Chi-Square Tests}

\begin{tabular}{|c|c|c|c|}
\hline & Value & $\mathrm{df}$ & $\begin{array}{c}\text { Asymp. Sig. (2- } \\
\text { sided) }\end{array}$ \\
\hline Pearson Chi-Square & $3.256^{\mathrm{a}}$ & 4 & .516 \\
\hline Likelihood Ratio & 4.164 & 4 & .384 \\
\hline Linear-by-Linear Association & .265 & 1 & .606 \\
\hline $\mathrm{N}$ of Valid Cases & 89 & & \\
\hline
\end{tabular}

a. 3 cells $(33.3 \%)$ have expected count less than 5 . The minimum expected count is 84 .

Directional Measures

\begin{tabular}{|ll|r|r|r|r|}
\hline & & $\begin{array}{c}\text { Asymp. Std. } \\
\text { Error }^{\mathrm{a}}\end{array}$ & Approx. T & $\begin{array}{c}\text { Approx. } \\
\text { Sig. }\end{array}$ \\
\hline Nominal by Nominal Lambda & Symmetric & Value & .022 & .015 & 1.430 \\
& Enrollment Dependent & .039 & .027 & 1.430 & .153 \\
\hline
\end{tabular}


ADHERENCE TO INSTRUCTIONAL PRACTICE GUIDELINES 114

\begin{tabular}{|ll|r|r|r|}
\hline & $\begin{array}{l}\text { Familiarity with } \\
\text { Guidelines Dependent }\end{array}$ & .000 & .000 &.$^{c}$ \\
\hline $\begin{array}{lll}\text { Goodman and Kruskal } \\
\text { tau }\end{array}$ & Enrollment Dependent & .020 & .012 & $.488^{\mathrm{d}}$ \\
& $\begin{array}{l}\text { Familiarity with } \\
\text { Guidelines Dependent }\end{array}$ & .007 & .012 & \\
\hline
\end{tabular}

a. Not assuming the null hypothesis.

b. Using the asymptotic standard error assuming the null hypothesis.

c. Cannot be computed because the asymptotic standard error equals zero.

d. Based on chi-square approximation

Symmetric Measures

\begin{tabular}{|ll|r|r|}
\hline & & Value & Approx. Sig. \\
\hline Nominal by Nominal & Phi & .191 & .516 \\
& Cramer's V & .135 & .516 \\
& Contingency Coefficient & .188 & .516 \\
N of Valid Cases & & 89 & \\
\hline
\end{tabular}




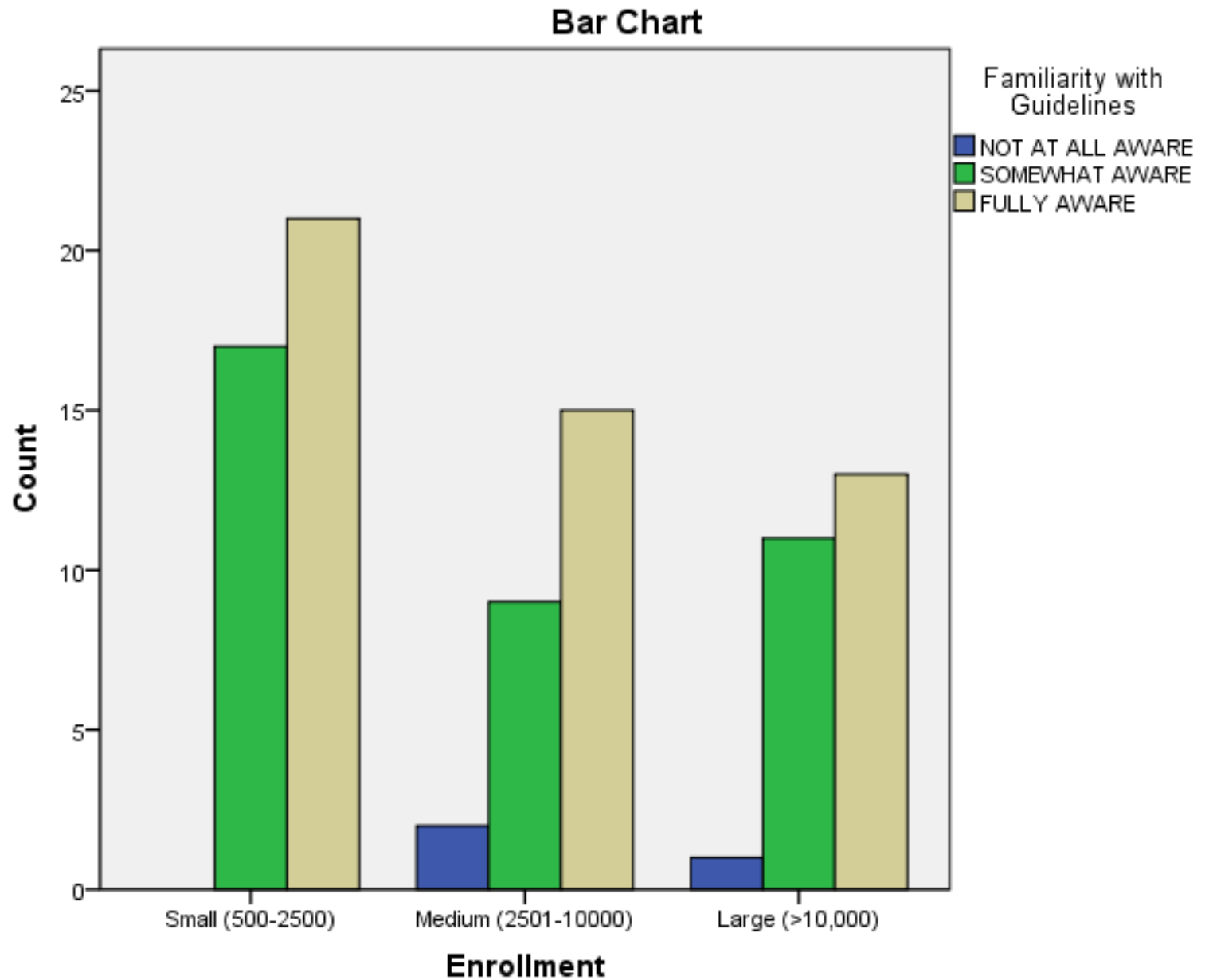

\section{Location(AAHPERD District) * Familiarity with Guidelines}

\begin{tabular}{|c|c|c|c|c|c|c|}
\hline \multicolumn{7}{|c|}{ Crosstab } \\
\hline & & & \multicolumn{3}{|c|}{ Familiarity with Guidelines } & \multirow[b]{2}{*}{ Total } \\
\hline & & & $\begin{array}{c}\text { NOT AT ALL } \\
\text { AWARE }\end{array}$ & $\begin{array}{c}\text { SOMEWHAT } \\
\text { AWARE }\end{array}$ & $\begin{array}{l}\text { FULLY } \\
\text { AWARE }\end{array}$ & \\
\hline \multirow{10}{*}{$\begin{array}{l}\text { Location(AAHPERD } \\
\text { District) }\end{array}$} & NORTHWEST & Count & 0 & 3 & 4 & 7 \\
\hline & & Expected Count & .2 & 2.9 & 3.9 & 7.0 \\
\hline & & $\%$ within & $.0 \%$ & $42.9 \%$ & $57.1 \%$ & $100.0 \%$ \\
\hline & & Location(AAHPERD & & & & \\
\hline & & District) & & & & \\
\hline & & $\%$ within Familiarity with & $.0 \%$ & $8.1 \%$ & $8.2 \%$ & $7.9 \%$ \\
\hline & & Guidelines & & & & \\
\hline & & $\%$ of Total & $.0 \%$ & $3.4 \%$ & $4.5 \%$ & $7.9 \%$ \\
\hline & SOUTHWEST & Count & 0 & 3 & 2 & 5 \\
\hline & & Expected Count & .2 & 2.1 & 2.8 & 5.0 \\
\hline
\end{tabular}


ADHERENCE TO INSTRUCTIONAL PRACTICE GUIDELINES 116

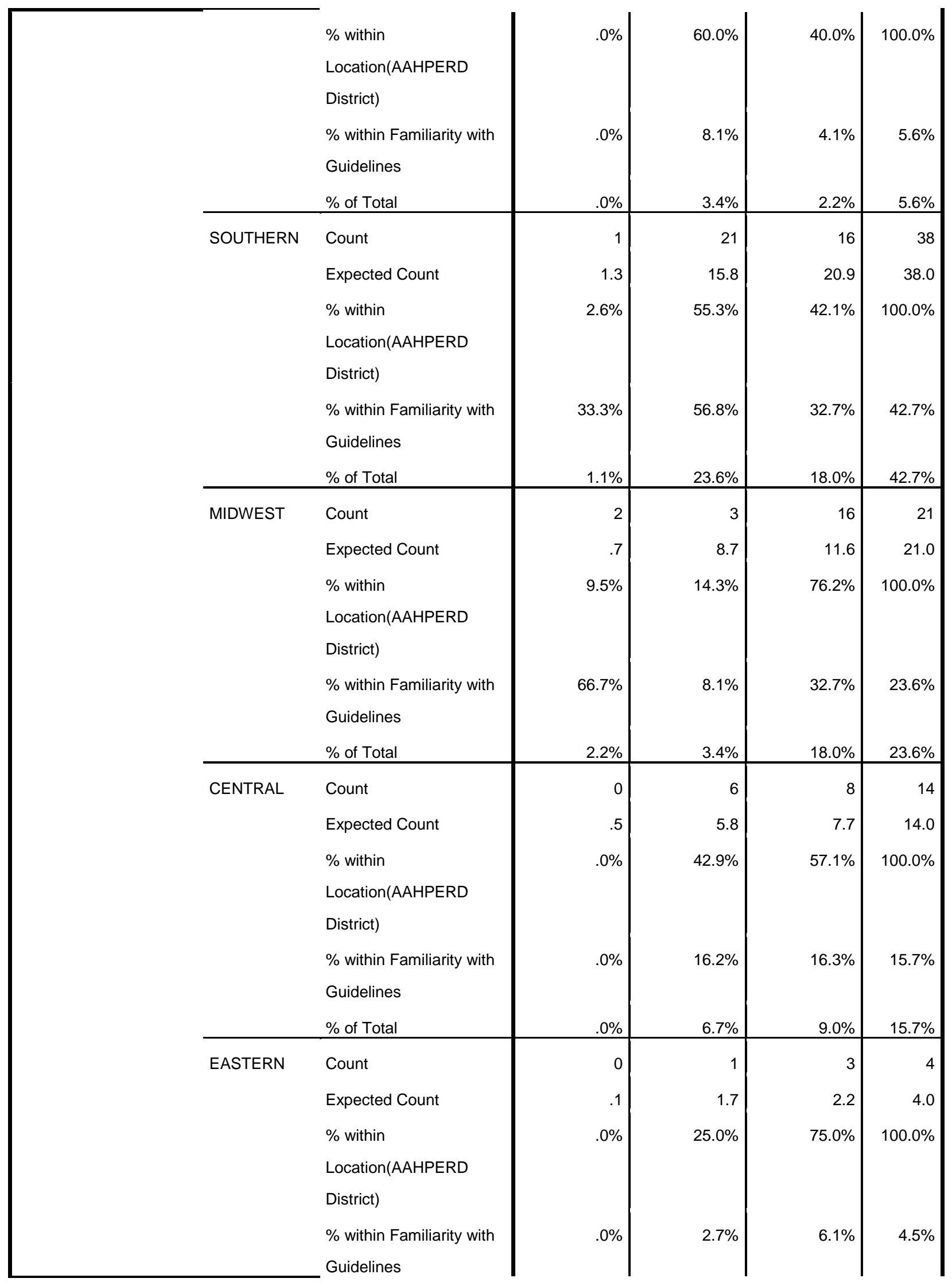


ADHERENCE TO INSTRUCTIONAL PRACTICE GUIDELINES 117

\begin{tabular}{|c|c|c|c|c|c|}
\hline & $\%$ of Total & $.0 \%$ & $1.1 \%$ & $3.4 \%$ & $4.5 \%$ \\
\hline \multirow[t]{8}{*}{ Total } & Count & 3 & 37 & 49 & 89 \\
\hline & Expected Count & 3.0 & 37.0 & 49.0 & 89.0 \\
\hline & $\%$ within & $3.4 \%$ & $41.6 \%$ & $55.1 \%$ & $100.0 \%$ \\
\hline & Location(AAHPERD & & & & \\
\hline & District) & & & & \\
\hline & $\%$ within Familiarity with & $100.0 \%$ & $100.0 \%$ & $100.0 \%$ & $100.0 \%$ \\
\hline & Guidelines & & & & \\
\hline & $\%$ of Total & $3.4 \%$ & $41.6 \%$ & $55.1 \%$ & $100.0 \%$ \\
\hline
\end{tabular}

\section{Chi-Square Tests}

\begin{tabular}{|l|r|r|r|}
\hline & & & \multicolumn{2}{|c|}{$\begin{array}{c}\text { Asymp. Sig. (2- } \\
\text { sided) }\end{array}$} \\
\hline Pearson Chi-Square & $12.960^{\mathrm{a}}$ & 10 & .226 \\
Likelihood Ratio & 14.222 & 10 & .163 \\
Linear-by-Linear Association & 1.314 & 1 & .252 \\
N of Valid Cases & 89 & & \\
\hline
\end{tabular}

a. 12 cells $(66.7 \%)$ have expected count less than 5 . The minimum expected count is .13 .

Directional Measures

\begin{tabular}{|c|c|c|c|c|c|c|}
\hline & & & Value & $\begin{array}{c}\text { Asymp. Std. } \\
\text { Error }^{\mathrm{a}}\end{array}$ & Approx. $\mathrm{T}^{\mathrm{b}}$ & $\begin{array}{l}\text { Approx. } \\
\text { Sig. }\end{array}$ \\
\hline \multirow[t]{9}{*}{ Nominal by Nominal } & \multirow[t]{5}{*}{ Lambda } & Symmetric & .077 & .112 & .672 & .501 \\
\hline & & Location(AAHPERD & .020 & .115 & .169 & .866 \\
\hline & & District) Dependent & & & & \\
\hline & & Familiarity with & .150 & .149 & .930 & .352 \\
\hline & & Guidelines Dependent & & & & \\
\hline & \multirow{4}{*}{$\begin{array}{l}\text { Goodman and Kruskal } \\
\text { tau }\end{array}$} & Location(AAHPERD & \multirow[t]{2}{*}{.051} & \multirow[t]{2}{*}{.028} & & \multirow[t]{2}{*}{$.014^{\mathrm{c}}$} \\
\hline & & District) Dependent & & & & \\
\hline & & Familiarity with & \multirow[t]{2}{*}{.097} & \multirow[t]{2}{*}{.052} & & \multirow[t]{2}{*}{$.071^{\mathrm{c}}$} \\
\hline & & Guidelines Dependent & & & & \\
\hline
\end{tabular}


ADHERENCE TO INSTRUCTIONAL PRACTICE GUIDELINES 118

Directional Measures

\begin{tabular}{|c|c|c|c|c|c|c|}
\hline & & & Value & $\begin{array}{c}\text { Asymp. Std. } \\
\text { Error }^{\mathrm{a}}\end{array}$ & Approx. $\mathrm{T}^{\mathrm{b}}$ & $\begin{array}{c}\text { Approx. } \\
\text { Sig. }\end{array}$ \\
\hline \multirow[t]{9}{*}{ Nominal by Nominal } & \multirow[t]{5}{*}{ Lambda } & Symmetric & .077 & .112 & .672 & .501 \\
\hline & & Location(AAHPERD & .020 & .115 & .169 & .866 \\
\hline & & District) Dependent & & & & \\
\hline & & Familiarity with & .150 & .149 & .930 & .352 \\
\hline & & Guidelines Dependent & & & & \\
\hline & \multirow{4}{*}{$\begin{array}{l}\text { Goodman and Kruskal } \\
\text { tau }\end{array}$} & Location(AAHPERD & \multirow[t]{2}{*}{.051} & \multirow[t]{2}{*}{.028} & & \multirow[t]{2}{*}{$.014^{\circ}$} \\
\hline & & District) Dependent & & & & \\
\hline & & Familiarity with & \multirow[t]{2}{*}{.097} & \multirow[t]{2}{*}{.052} & & \multirow[t]{2}{*}{$.071^{\mathrm{c}}$} \\
\hline & & Guidelines Dependent & & & & \\
\hline
\end{tabular}

a. Not assuming the null hypothesis.

b. Using the asymptotic standard error assuming the null hypothesis.

c. Based on chi-square approximation

Symmetric Measures

\begin{tabular}{|ll|r|r|}
\hline & & \multicolumn{1}{|c|}{ Value } & Approx. Sig. \\
\hline Nominal by Nominal & Phi & .382 & .226 \\
& Cramer's V & .270 & .226 \\
& Contingency Coefficient & .357 & .226 \\
N of Valid Cases & & 89 & \\
\hline
\end{tabular}


ADHERENCE TO INSTRUCTIONAL PRACTICE GUIDELINES 119

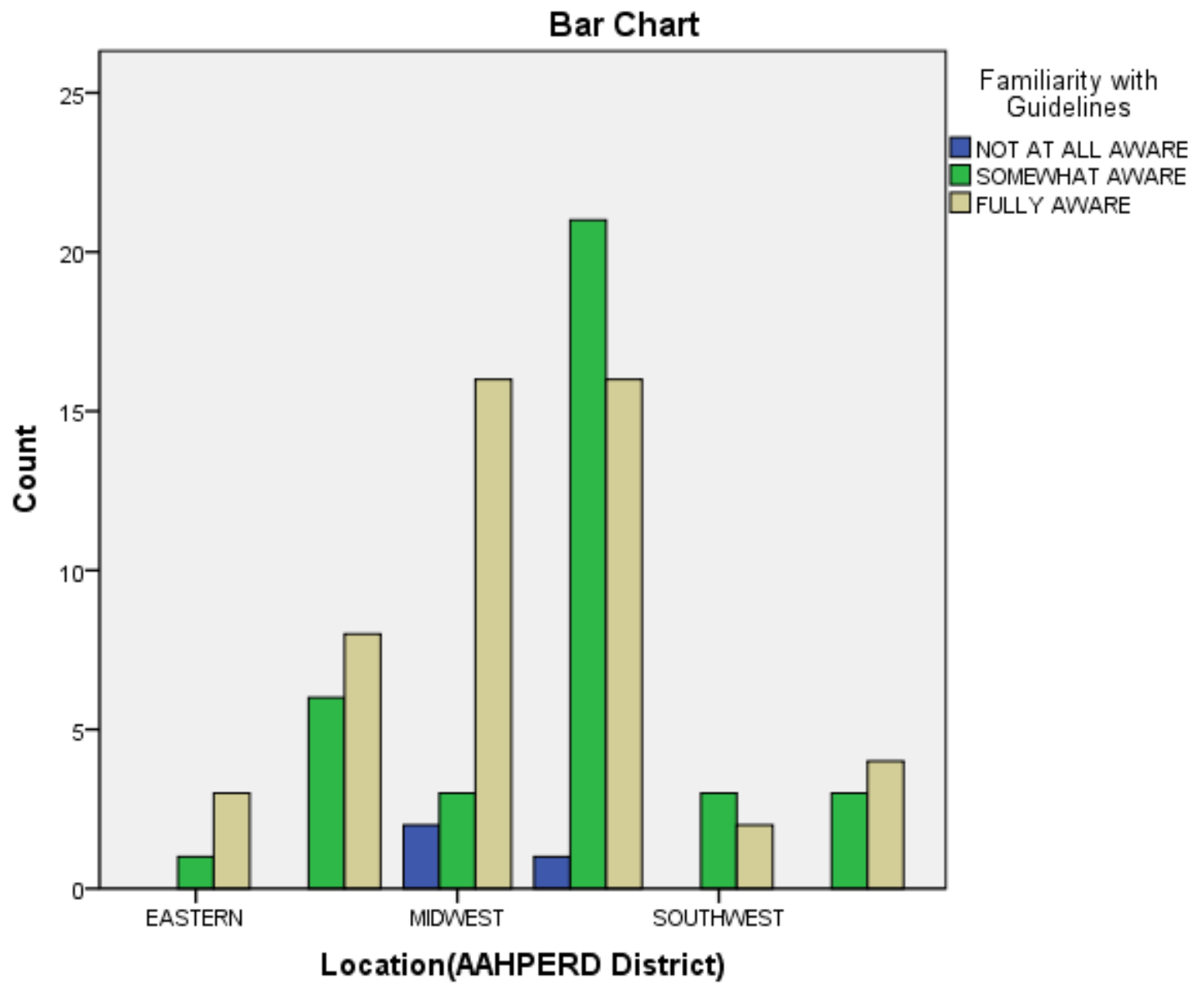




\section{Appendix H: Overall Adherence and Institutional Variables}

\section{Crosstabs}

Notes

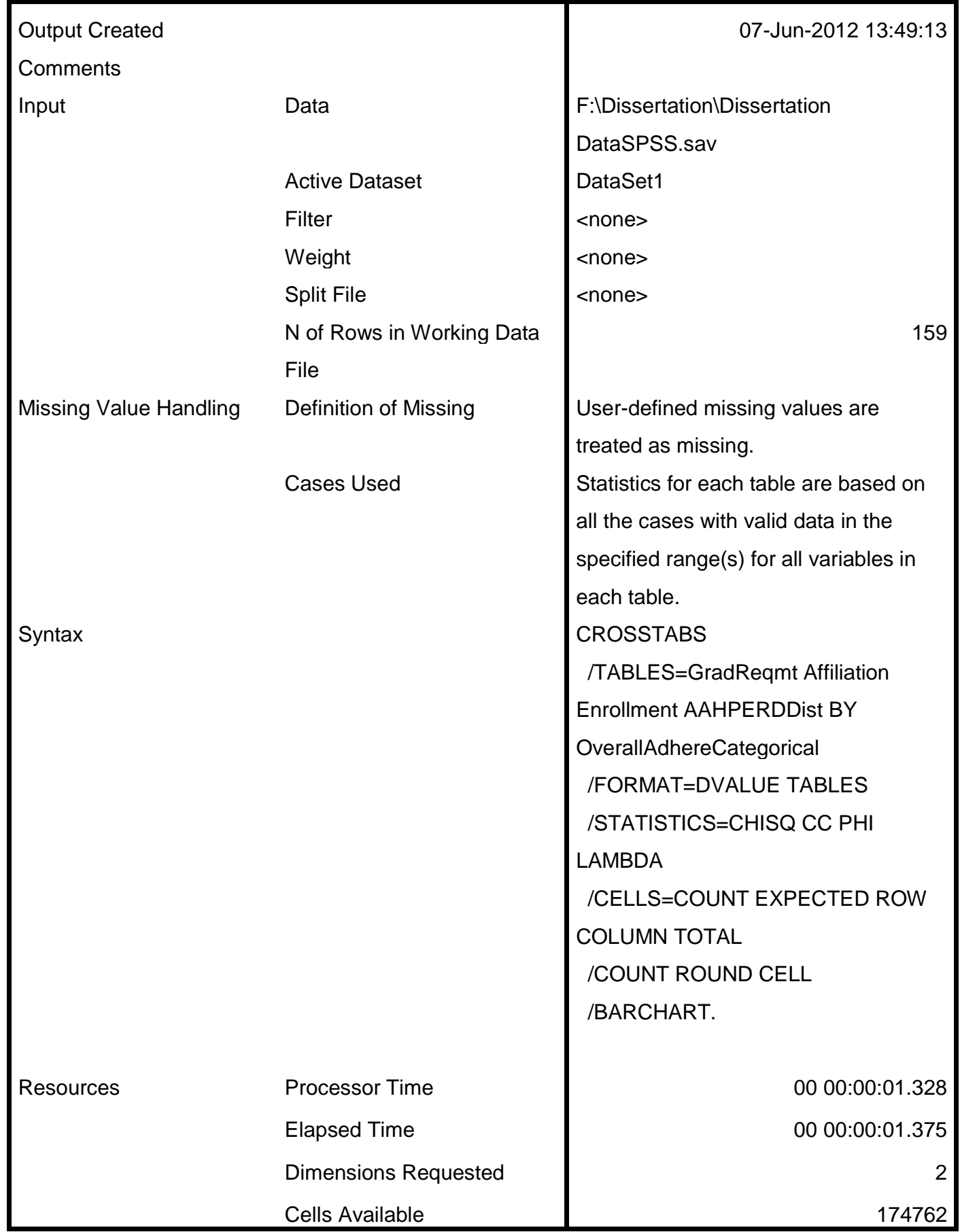

[DataSet1] F:IDissertation\Dissertation DataSPSS.sav 
Case Processing Summary

\begin{tabular}{|c|c|c|c|c|c|c|}
\hline & \multicolumn{6}{|c|}{ Cases } \\
\hline & \multicolumn{2}{|c|}{ Valid } & \multicolumn{2}{|c|}{ Missing } & \multicolumn{2}{|c|}{ Total } \\
\hline & $\mathrm{N}$ & Percent & $\mathrm{N}$ & Percent & $\mathrm{N}$ & Percent \\
\hline PE Graduation Requirement & 90 & $56.6 \%$ & 69 & $43.4 \%$ & 159 & $100.0 \%$ \\
\hline * Overall Adherence & & & & & & \\
\hline Affiliation * Overall & 90 & $56.6 \%$ & 69 & $43.4 \%$ & 159 & $100.0 \%$ \\
\hline Adherence & & & & & & \\
\hline Enrollment * Overall & 90 & $56.6 \%$ & 69 & $43.4 \%$ & 159 & $100.0 \%$ \\
\hline Adherence & & & & & & \\
\hline Location(AAHPERD District) & 90 & $56.6 \%$ & 69 & $43.4 \%$ & 159 & $100.0 \%$ \\
\hline * Overall Adherence & & & & & & \\
\hline
\end{tabular}

\section{PE Graduation Requirement * Overall Adherence}

Crosstab

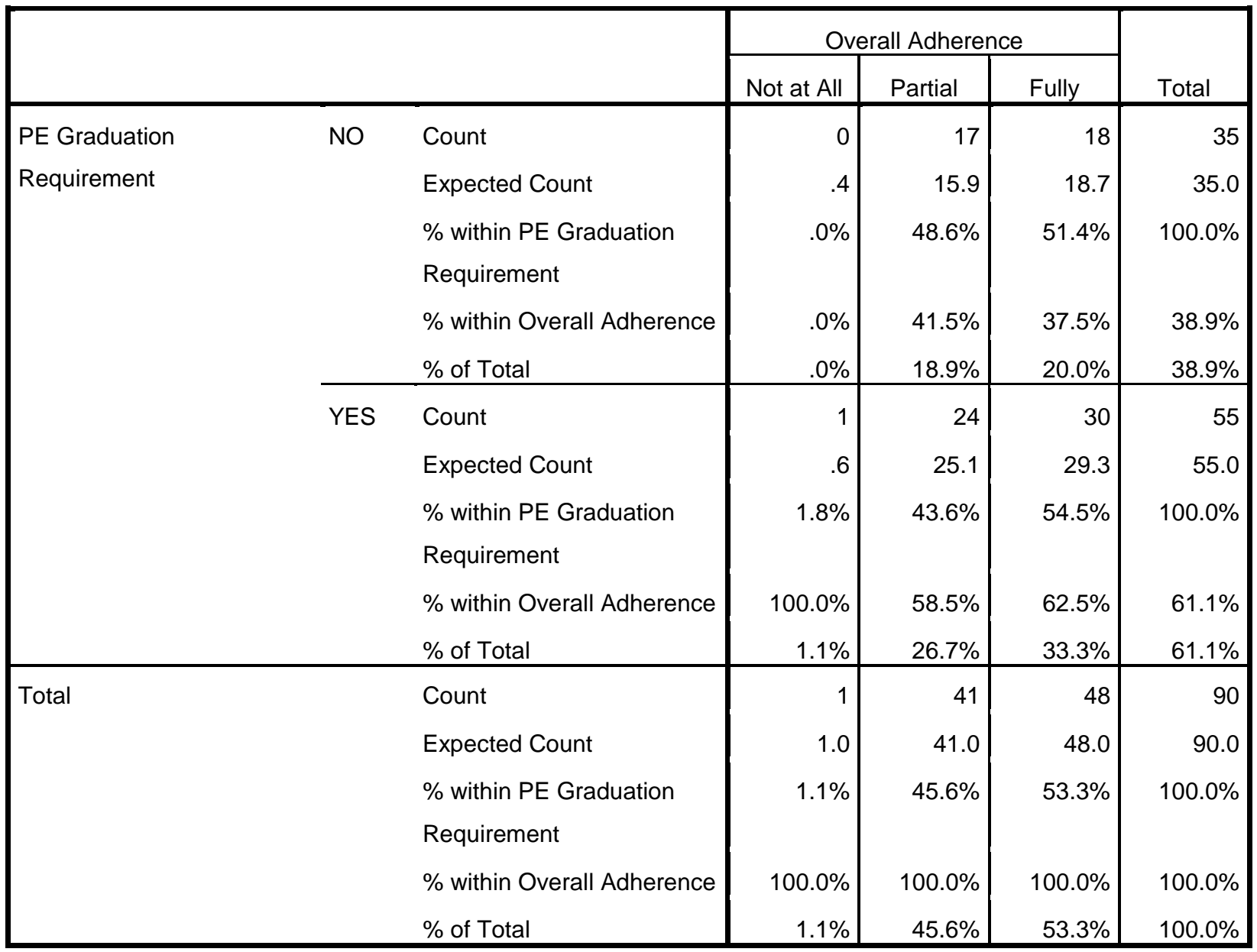




\section{Chi-Square Tests}

\begin{tabular}{|l|r|r|r|}
\hline & \multicolumn{1}{|c|}{ Value } & df & \multicolumn{2}{|c|}{$\begin{array}{c}\text { Asymp. Sig. (2- } \\
\text { sided) }\end{array}$} \\
\hline Pearson Chi-Square & $.790^{\mathrm{a}}$ & 2 & .674 \\
Likelihood Ratio & 1.138 & 2 & .566 \\
Linear-by-Linear Association & .013 & 1 & .909 \\
N of Valid Cases & 90 & & \\
\end{tabular}

a. 2 cells (33.3\%) have expected count less than 5 . The minimum expected count is 39 .

\section{Directional Measures}

\begin{tabular}{|c|c|c|c|c|c|c|}
\hline & & & Value & $\begin{array}{c}\text { Asymp. Std. } \\
\text { Error }^{\mathrm{a}}\end{array}$ & Approx. T & $\begin{array}{l}\text { Approx. } \\
\text { Sig. }\end{array}$ \\
\hline \multirow[t]{9}{*}{ Nominal by Nominal } & \multirow[t]{5}{*}{ Lambda } & Symmetric & .000 & .000 &.$^{b}$ &. \\
\hline & & PE Graduation & .000 & .000 &.$^{\mathrm{b}}$ &.$^{b}$ \\
\hline & & Requirement Dependent & & & & \\
\hline & & Overall Adherence & .000 & .000 &.$^{\mathrm{b}}$ & . \\
\hline & & Dependent & & & & \\
\hline & \multirow{4}{*}{$\begin{array}{l}\text { Goodman and Kruskal } \\
\text { tau }\end{array}$} & PE Graduation & \multirow[t]{2}{*}{.009} & \multirow[t]{2}{*}{.009} & & \multirow{2}{*}{$.677^{\circ}$} \\
\hline & & Requirement Dependent & & & & \\
\hline & & Overall Adherence & \multirow[t]{2}{*}{.002} & \multirow[t]{2}{*}{.008} & & \multirow[t]{2}{*}{$.856^{\mathrm{c}}$} \\
\hline & & Dependent & & & & \\
\hline
\end{tabular}

a. Not assuming the null hypothesis.

b. Cannot be computed because the asymptotic standard error equals zero.

c. Based on chi-square approximation

\section{Symmetric Measures}

\begin{tabular}{|ll|r|r|}
\hline & & & \\
\hline Nominal by Nominal & Phi & Value & Approx. Sig. \\
& Cramer's V & .094 & .674 \\
& Contingency Coefficient & .094 & .674 \\
& & .093 & .674 \\
\hline
\end{tabular}


ADHERENCE TO INSTRUCTIONAL PRACTICE GUIDELINES 123

Symmetric Measures

\begin{tabular}{|ll|r|r|}
\hline & & Value & Approx. Sig. \\
\hline Nominal by Nominal & Phi & .094 & .674 \\
& Cramer's V & .094 & .674 \\
& Contingency Coefficient & .093 & .674 \\
N of Valid Cases & & 90 & \\
\hline
\end{tabular}

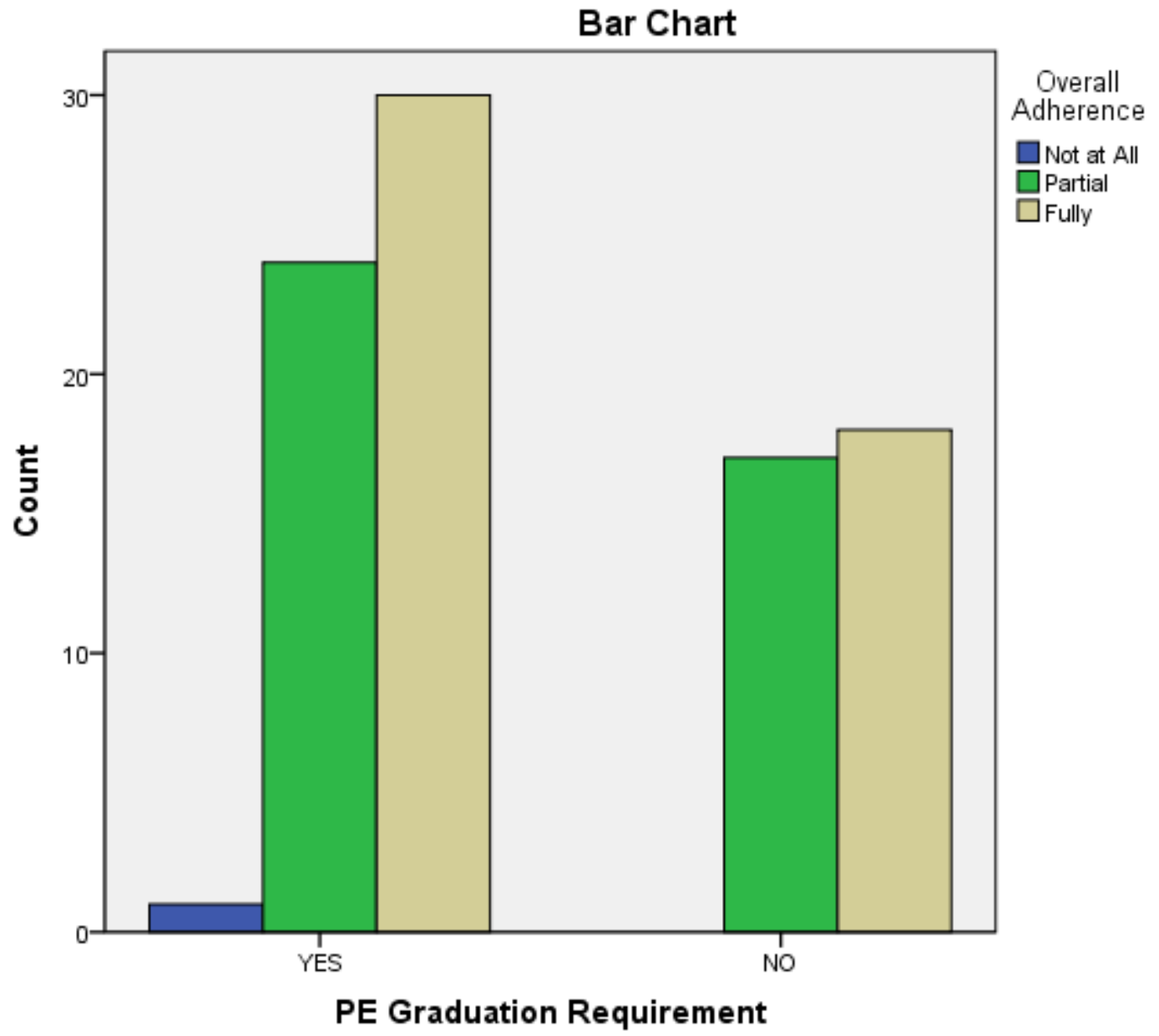


Affiliation * Overall Adherence

\begin{tabular}{|c|c|c|c|c|c|c|}
\hline & & & \multicolumn{3}{|c|}{ Overall Adherence } & \multirow[b]{2}{*}{ Total } \\
\hline & & & Not at All & Partial & Fully & \\
\hline \multirow[t]{10}{*}{ Affiliation } & PRIVATE & Count & 1 & 18 & 22 & 41 \\
\hline & & Expected Count & .5 & 18.2 & 22.3 & 41.0 \\
\hline & & $\%$ within Affiliation & $2.4 \%$ & $43.9 \%$ & $53.7 \%$ & $100.0 \%$ \\
\hline & & $\%$ within Overall Adherence & $100.0 \%$ & $45.0 \%$ & $44.9 \%$ & $45.6 \%$ \\
\hline & & $\%$ of Total & $1.1 \%$ & $20.0 \%$ & $24.4 \%$ & $45.6 \%$ \\
\hline & PUBLIC & Count & 0 & 22 & 27 & 49 \\
\hline & & Expected Count & .5 & 21.8 & 26.7 & 49.0 \\
\hline & & $\%$ within Affiliation & $.0 \%$ & $44.9 \%$ & $55.1 \%$ & $100.0 \%$ \\
\hline & & $\%$ within Overall Adherence & $.0 \%$ & $55.0 \%$ & $55.1 \%$ & $54.4 \%$ \\
\hline & & $\%$ of Total & $.0 \%$ & $24.4 \%$ & $30.0 \%$ & $54.4 \%$ \\
\hline \multirow[t]{5}{*}{ Total } & & Count & 1 & 40 & 49 & 90 \\
\hline & & Expected Count & 1.0 & 40.0 & 49.0 & 90.0 \\
\hline & & $\%$ within Affiliation & $1.1 \%$ & $44.4 \%$ & $54.4 \%$ & $100.0 \%$ \\
\hline & & $\%$ within Overall Adherence & $100.0 \%$ & $100.0 \%$ & $100.0 \%$ & $100.0 \%$ \\
\hline & & $\%$ of Total & $1.1 \%$ & $44.4 \%$ & $54.4 \%$ & $100.0 \%$ \\
\hline
\end{tabular}

\section{Chi-Square Tests}

\begin{tabular}{|c|c|c|c|}
\hline & Value & $\mathrm{df}$ & $\begin{array}{c}\text { Asymp. Sig. (2- } \\
\text { sided) }\end{array}$ \\
\hline Pearson Chi-Square & $1.209^{\mathrm{a}}$ & 2 & .546 \\
\hline Likelihood Ratio & 1.586 & 2 & .452 \\
\hline Linear-by-Linear Association & .123 & 1 & .726 \\
\hline $\mathrm{N}$ of Valid Cases & 90 & & \\
\hline
\end{tabular}

a. 2 cells (33.3\%) have expected count less than 5 . The minimum expected count is .46 .

Directional Measures

\begin{tabular}{|c|c|c|c|c|c|}
\hline & & Value & $\begin{array}{c}\text { Asymp. Std. } \\
\text { Error }^{\mathrm{a}}\end{array}$ & Approx. $\mathrm{T}^{\mathrm{b}}$ & $\begin{array}{c}\text { Approx. } \\
\text { Sig. }\end{array}$ \\
\hline Nominal by Nominal Lambda & Symmetric & .012 & .012 & 1.006 & .315 \\
\hline
\end{tabular}


ADHERENCE TO INSTRUCTIONAL PRACTICE GUIDELINES 125

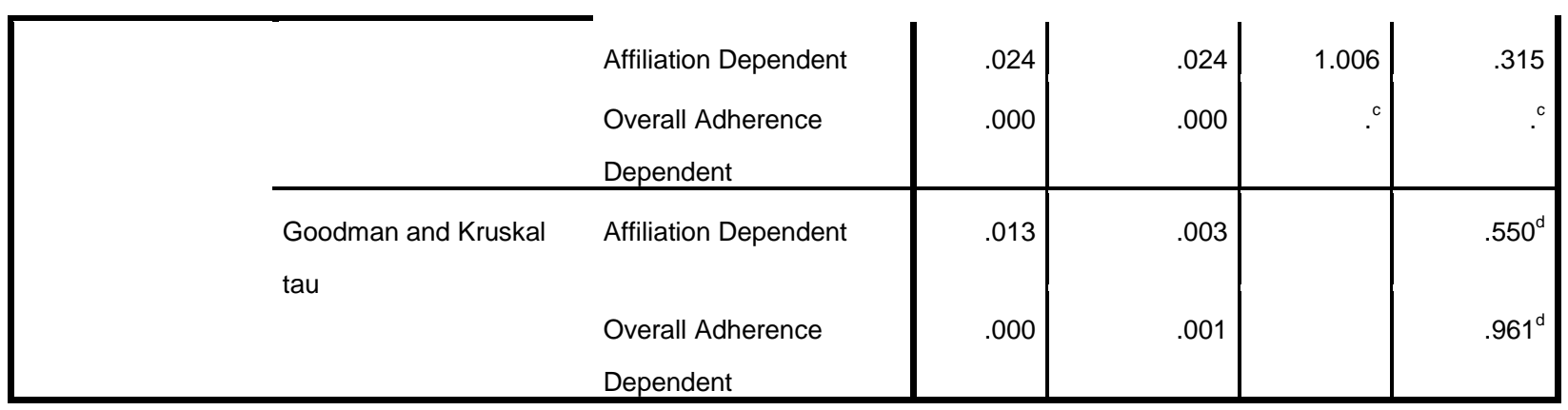

a. Not assuming the null hypothesis.

b. Using the asymptotic standard error assuming the null hypothesis.

c. Cannot be computed because the asymptotic standard error equals zero.

d. Based on chi-square approximation

Symmetric Measures

\begin{tabular}{|ll|r|r|}
\hline & & Value & Approx. Sig. \\
\hline Nominal by Nominal & Phi & .116 & .546 \\
& Cramer's V & .116 & .546 \\
& Contingency Coefficient & .115 & .546 \\
N of Valid Cases & & 90 & \\
\hline
\end{tabular}




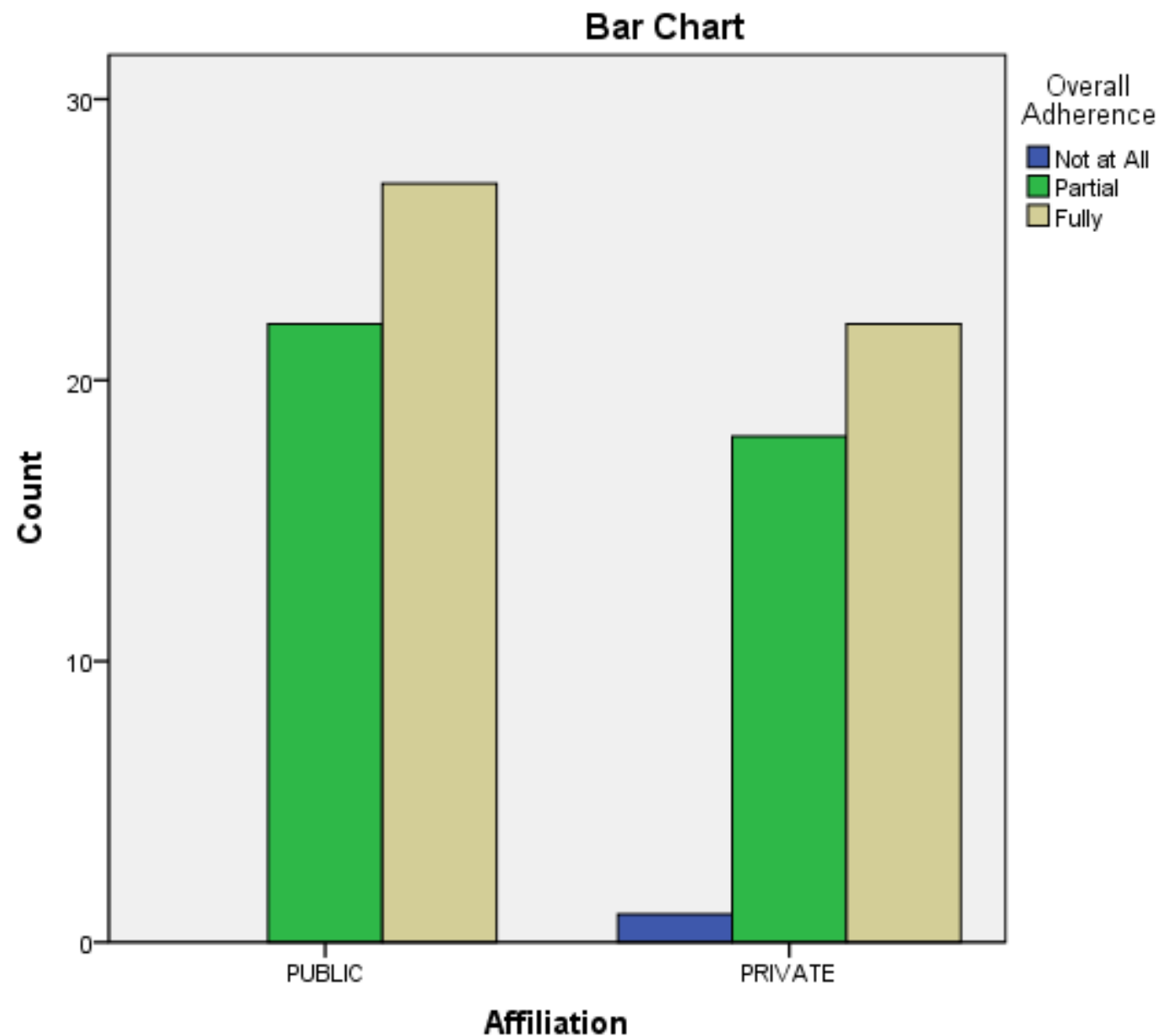

Enrollment * Overall Adherence

\begin{tabular}{|c|c|c|c|c|c|c|}
\hline \multicolumn{7}{|c|}{ Crosstab } \\
\hline & & & \multicolumn{3}{|c|}{ Overall Adherence } & \multirow[b]{2}{*}{ Total } \\
\hline & & & Not at All & Partial & Fully & \\
\hline \multirow[t]{9}{*}{ Enrollment } & Large $(>10,000)$ & Count & 0 & 14 & 11 & 25 \\
\hline & & Expected Count & 3 & 11.1 & 13.6 & 25.0 \\
\hline & & $\%$ within Enrollment & $.0 \%$ & $56.0 \%$ & $44.0 \%$ & $100.0 \%$ \\
\hline & & $\%$ within Overall & $.0 \%$ & $35.0 \%$ & $22.4 \%$ & $27.8 \%$ \\
\hline & & Adherence & & & & \\
\hline & & $\%$ of Total & $.0 \%$ & $15.6 \%$ & $12.2 \%$ & $27.8 \%$ \\
\hline & Medium (2501-10000) & Count & 0 & 9 & 18 & 27 \\
\hline & & Expected Count & .3 & 12.0 & 14.7 & 27.0 \\
\hline & & $\%$ within Enrollment & $.0 \%$ & $33.3 \%$ & $66.7 \%$ & $100.0 \%$ \\
\hline
\end{tabular}


ADHERENCE TO INSTRUCTIONAL PRACTICE GUIDELINES 127

\begin{tabular}{|c|c|c|c|c|c|c|}
\hline & & $\begin{array}{l}\% \text { within Overall } \\
\text { Adherence } \\
\% \text { of Total }\end{array}$ & $\begin{array}{l}.0 \% \\
.0 \% \\
\end{array}$ & $\begin{array}{l}22.5 \% \\
10.0 \% \\
\end{array}$ & $\begin{array}{l}36.7 \% \\
20.0 \% \\
\end{array}$ & $\begin{array}{l}30.0 \% \\
30.0 \% \\
\end{array}$ \\
\hline & Small (500-2500) & Count & 1 & 17 & 20 & 38 \\
\hline & & Expected Count & .4 & 16.9 & 20.7 & 38.0 \\
\hline & & $\%$ within Enrollment & $2.6 \%$ & $44.7 \%$ & $52.6 \%$ & $100.0 \%$ \\
\hline & & $\%$ within Overall & $100.0 \%$ & $42.5 \%$ & $40.8 \%$ & $42.2 \%$ \\
\hline & & Adherence & & & & \\
\hline & & $\%$ of Total & $1.1 \%$ & $18.9 \%$ & $22.2 \%$ & $42.2 \%$ \\
\hline Total & & Count & 1 & 40 & 49 & 90 \\
\hline & & Expected Count & 1.0 & 40.0 & 49.0 & 90.0 \\
\hline & & $\%$ within Enrollment & $1.1 \%$ & $44.4 \%$ & $54.4 \%$ & $100.0 \%$ \\
\hline & & $\%$ within Overall & $100.0 \%$ & $100.0 \%$ & $100.0 \%$ & $100.0 \%$ \\
\hline & & Adherence & & & & \\
\hline & & $\%$ of Total & $1.1 \%$ & $44.4 \%$ & $54.4 \%$ & $100.0 \%$ \\
\hline
\end{tabular}

\section{Chi-Square Tests}

\begin{tabular}{|l|r|r|r|}
\hline & Value & df & \multicolumn{1}{c|}{$\begin{array}{c}\text { Asymp. Sig. (2- } \\
\text { sided) }\end{array}$} \\
\hline Pearson Chi-Square & $4.135^{\mathrm{a}}$ & 4 & .388 \\
Likelihood Ratio & 4.491 & 4 & .344 \\
Linear-by-Linear Association & .068 & 1 & .794 \\
N of Valid Cases & 90 & & \\
\hline
\end{tabular}

a. 3 cells $(33.3 \%)$ have expected count less than 5 . The minimum expected count is 28 .

Directional Measures

\begin{tabular}{|c|c|c|c|c|c|}
\hline & & Value & $\begin{array}{c}\text { Asymp. Std. } \\
\text { Error }^{\mathrm{a}}\end{array}$ & Approx. $T^{b}$ & $\begin{array}{c}\text { Approx. } \\
\text { Sig. }\end{array}$ \\
\hline \multirow[t]{4}{*}{ Nominal by Nominal Lambda } & Symmetric & .032 & .053 & .601 & .548 \\
\hline & Enrollment Dependent & .000 & .000 &.$^{c}$ & \\
\hline & Overall Adherence & .073 & .117 & .601 & .548 \\
\hline & Dependent & & & & \\
\hline
\end{tabular}


ADHERENCE TO INSTRUCTIONAL PRACTICE GUIDELINES 128

\begin{tabular}{|ll|r|r|r|}
\hline \begin{tabular}{ll|l|l|} 
Goodman and Kruskal \\
tau
\end{tabular} & $\begin{array}{l}\text { Enrollment Dependent } \\
\text { Overall Adherence } \\
\text { Dependent }\end{array}$ & .022 & .016 & $.413^{\mathrm{d}}$ \\
& $.252^{\mathrm{d}}$ \\
\hline
\end{tabular}

a. Not assuming the null hypothesis.

b. Using the asymptotic standard error assuming the null hypothesis.

c. Cannot be computed because the asymptotic standard error equals zero.

d. Based on chi-square approximation

Symmetric Measures

\begin{tabular}{|ll|r|r|}
\hline & & \multicolumn{1}{|c|}{ Value } & Approx. Sig. \\
\hline Nominal by Nominal & Phi & .214 & .388 \\
& Cramer's V & .152 & .388 \\
& Contingency Coefficient & .210 & .388 \\
N of Valid Cases & & 90 & \\
\hline
\end{tabular}




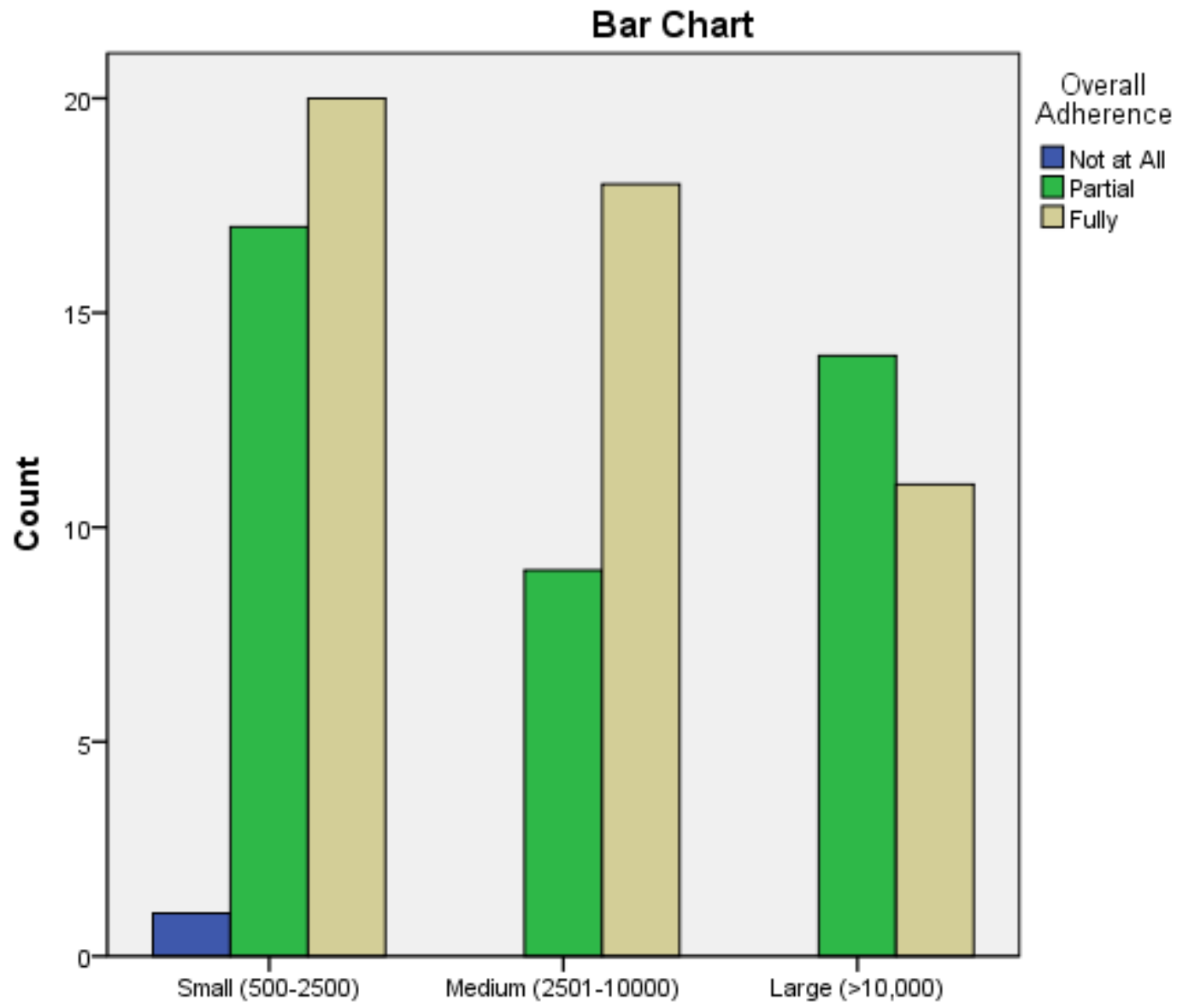

Enrollment

\section{Location(AAHPERD District) * Overall Adherence}

\begin{tabular}{|c|c|c|c|c|c|c|}
\hline \multicolumn{7}{|c|}{ Crosstab } \\
\hline & & & \multicolumn{3}{|c|}{ Overall Adherence } & \multirow[b]{2}{*}{ Total } \\
\hline & & & Not at All & Partial & Fully & \\
\hline \multirow{10}{*}{$\begin{array}{l}\text { Location(AAHPERD } \\
\text { District) }\end{array}$} & NORTHWEST & Count & 1 & 3 & 3 & 7 \\
\hline & & Expected Count & .1 & 3.1 & 3.8 & 7.0 \\
\hline & & $\%$ within & $14.3 \%$ & $42.9 \%$ & $42.9 \%$ & $100.0 \%$ \\
\hline & & Location(AAHPERD & & & & \\
\hline & & District) & & & & \\
\hline & & $\%$ within Overall & $100.0 \%$ & $7.5 \%$ & $6.1 \%$ & $7.8 \%$ \\
\hline & & Adherence & & & & \\
\hline & & $\%$ of Total & $1.1 \%$ & $3.3 \%$ & $3.3 \%$ & $7.8 \%$ \\
\hline & SOUTHWEST & Count & 0 & 1 & 4 & 5 \\
\hline & & Expected Count & .1 & 2.2 & 2.7 & 5.0 \\
\hline
\end{tabular}


ADHERENCE TO INSTRUCTIONAL PRACTICE GUIDELINES 130

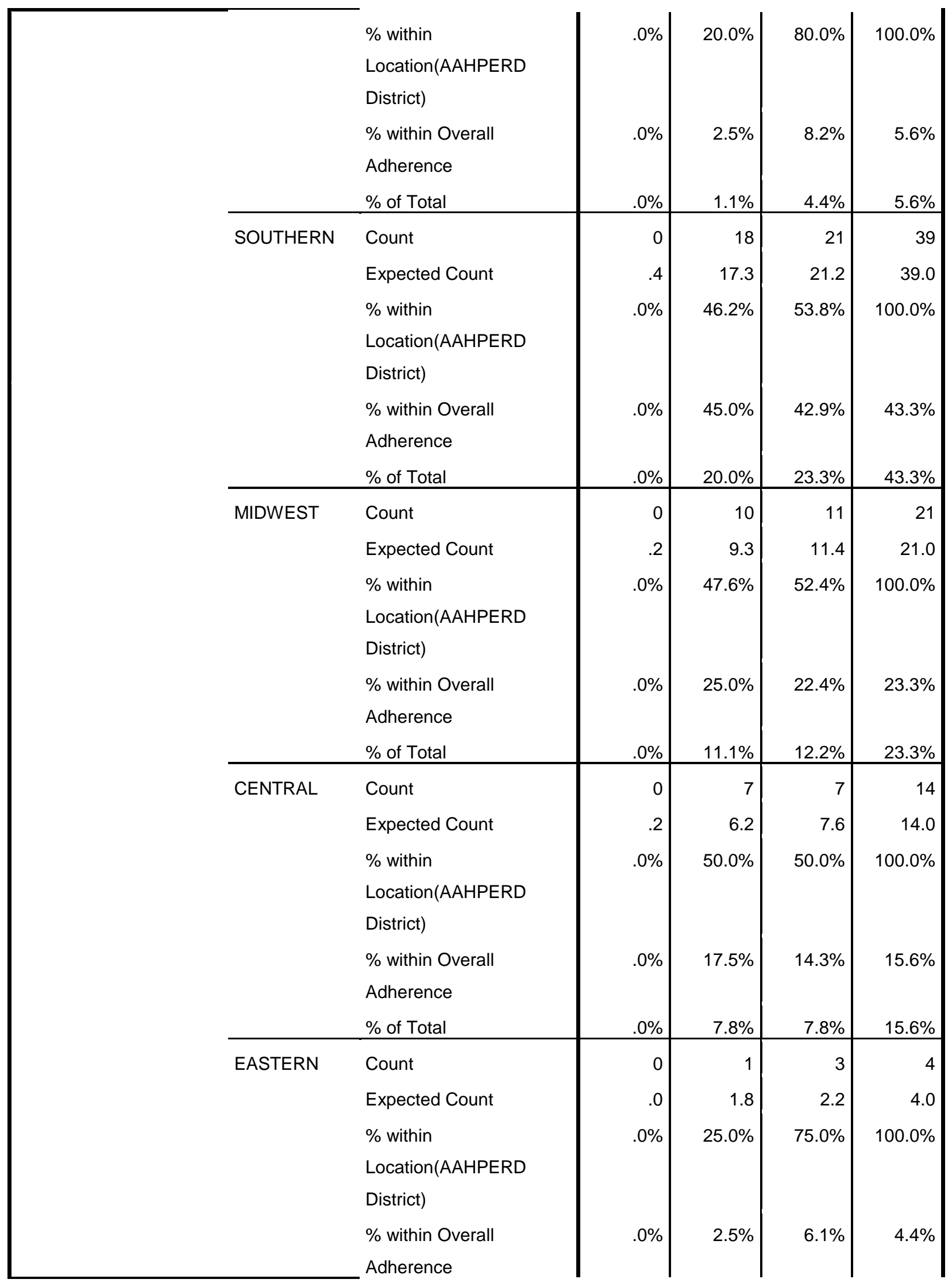


ADHERENCE TO INSTRUCTIONAL PRACTICE GUIDELINES 131

\begin{tabular}{|ll|r|r|r|r|}
\hline & \% of Total & $.0 \%$ & $1.1 \%$ & $3.3 \%$ & $4.4 \%$ \\
\hline Total & Count & 1 & 40 & 49 & 90 \\
& Expected Count & 1.0 & 40.0 & 49.0 & 90.0 \\
& $\%$ within & $1.1 \%$ & $44.4 \%$ & $54.4 \%$ & $100.0 \%$ \\
& Location(AAHPERD & & & & \\
& District) & & & \\
& $\%$ within Overall & $100.0 \%$ & $100.0 \%$ & $100.0 \%$ & $100.0 \%$ \\
& Adherence & & & & \\
& $\%$ of Total & $1.1 \%$ & $44.4 \%$ & $54.4 \%$ & $100.0 \%$ \\
\hline
\end{tabular}

\section{Chi-Square Tests}

\begin{tabular}{|l|r|r|r|}
\hline & \multicolumn{1}{|c|}{ Value } & df & $\begin{array}{c}\text { Asymp. Sig. (2- } \\
\text { sided) }\end{array}$ \\
\hline Pearson Chi-Square & $14.197^{\mathrm{a}}$ & 10 & .164 \\
Likelihood Ratio & 7.588 & 10 & .669 \\
Linear-by-Linear Association & .374 & 1 & .541 \\
N of Valid Cases & 90 & & \\
\hline
\end{tabular}

a. 12 cells $(66.7 \%)$ have expected count less than 5 . The minimum expected count is .04 .

Directional Measures

\begin{tabular}{|c|c|c|c|c|c|c|}
\hline & & & Value & $\begin{array}{c}\text { Asymp. Std. } \\
\text { Error }^{\mathrm{a}}\end{array}$ & Approx. $T^{\mathrm{b}}$ & $\begin{array}{c}\text { Approx. } \\
\text { Sig. }\end{array}$ \\
\hline \multirow[t]{9}{*}{ Nominal by Nominal } & \multirow[t]{5}{*}{ Lambda } & Symmetric & .011 & .050 & .218 & .827 \\
\hline & & Location(AAHPERD & .020 & .019 & 1.006 & .315 \\
\hline & & District) Dependent & & & & \\
\hline & & Overall Adherence & .000 & .109 & .000 & 1.000 \\
\hline & & Dependent & & & & \\
\hline & \multirow{4}{*}{$\begin{array}{l}\text { Goodman and Kruskal } \\
\text { tau }\end{array}$} & Location(AAHPERD & \multirow[t]{2}{*}{.020} & \multirow[t]{2}{*}{.003} & & \multirow[t]{2}{*}{$.551^{\circ}$} \\
\hline & & District) Dependent & & & & \\
\hline & & Overall Adherence & \multirow[t]{2}{*}{.028} & \multirow[t]{2}{*}{.028} & & \multirow[t]{2}{*}{$.889^{\circ}$} \\
\hline & & Dependent & & & & \\
\hline
\end{tabular}


ADHERENCE TO INSTRUCTIONAL PRACTICE GUIDELINES 132

Directional Measures

\begin{tabular}{|c|c|c|c|c|c|c|}
\hline & & & Value & $\begin{array}{c}\text { Asymp. Std. } \\
\text { Error }^{\mathrm{a}}\end{array}$ & Approx. $\mathrm{T}^{\mathrm{b}}$ & $\begin{array}{c}\text { Approx. } \\
\text { Sig. }\end{array}$ \\
\hline \multirow[t]{9}{*}{ Nominal by Nominal } & \multirow[t]{5}{*}{ Lambda } & Symmetric & .011 & .050 & .218 & .827 \\
\hline & & Location(AAHPERD & .020 & .019 & 1.006 & .315 \\
\hline & & District) Dependent & & & & \\
\hline & & Overall Adherence & .000 & .109 & .000 & 1.000 \\
\hline & & Dependent & & & & \\
\hline & \multirow{4}{*}{$\begin{array}{l}\text { Goodman and Kruskal } \\
\text { tau }\end{array}$} & Location(AAHPERD & \multirow[t]{2}{*}{.020} & \multirow[t]{2}{*}{.003} & & \multirow[t]{2}{*}{$.551^{\circ}$} \\
\hline & & District) Dependent & & & & \\
\hline & & Overall Adherence & \multirow[t]{2}{*}{.028} & \multirow[t]{2}{*}{.028} & & \multirow[t]{2}{*}{.889} \\
\hline & & Dependent & & & & \\
\hline
\end{tabular}

a. Not assuming the null hypothesis.

b. Using the asymptotic standard error assuming the null hypothesis.

c. Based on chi-square approximation

Symmetric Measures

\begin{tabular}{|ll|r|r|}
\hline & & \multicolumn{1}{|c|}{ Value } & Approx. Sig. \\
\hline Nominal by Nominal & Phi & .397 & .164 \\
& Cramer's V & .281 & .164 \\
& Contingency Coefficient & .369 & .164 \\
N of Valid Cases & & 90 & \\
\hline
\end{tabular}


ADHERENCE TO INSTRUCTIONAL PRACTICE GUIDELINES 133

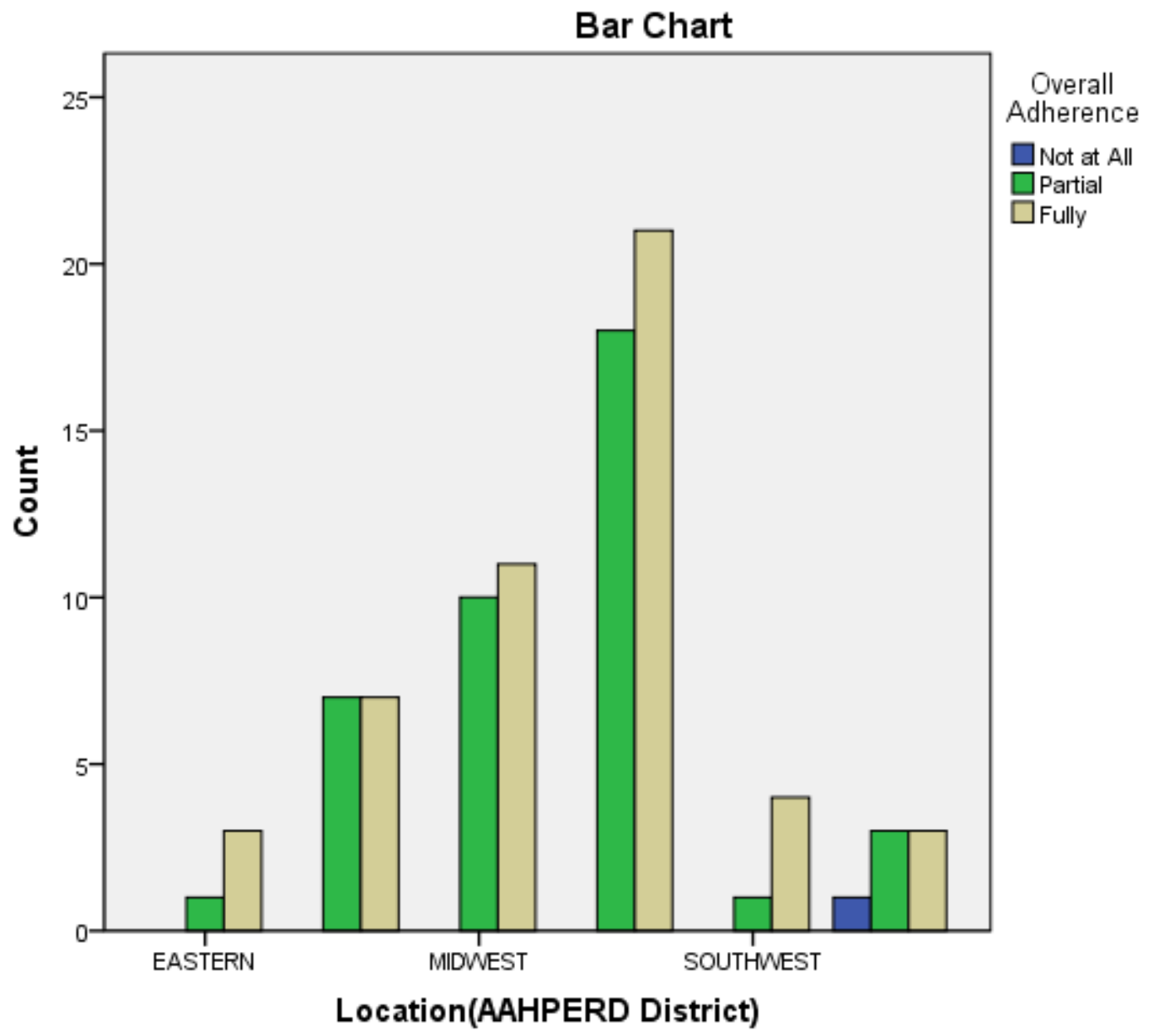


ADHERENCE TO INSTRUCTIONAL PRACTICE GUIDELINES 134

\section{Appendix I: Familiarity and Overall Adherence}

Familiarity with Guidelines * Overall Adherence Crosstabulation

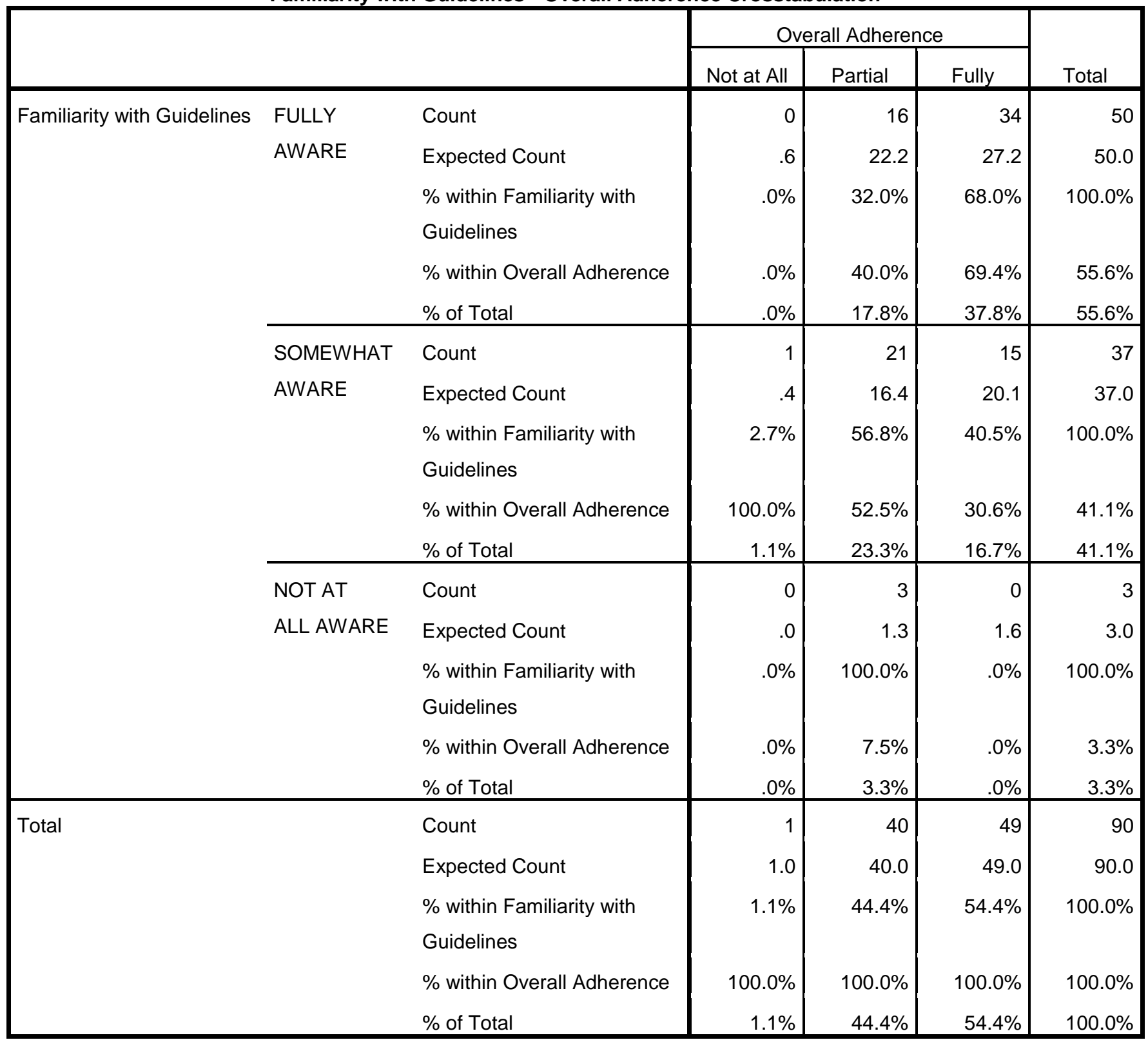

\section{Chi-Square Tests}

\begin{tabular}{|c|c|c|c|}
\hline & Value & $\mathrm{df}$ & $\begin{array}{l}\text { Asymp. Sig. (2- } \\
\text { sided) }\end{array}$ \\
\hline Pearson Chi-Square & $11.155^{\mathrm{a}}$ & 4 & .025 \\
\hline Likelihood Ratio & 12.674 & 4 & .013 \\
\hline Linear-by-Linear Association & 10.230 & 1 & .001 \\
\hline
\end{tabular}


a. 5 cells $(55.6 \%)$ have expected count less than 5 . The minimum expected count is .03 .

\begin{tabular}{|c|c|c|c|c|c|c|}
\hline \multicolumn{7}{|c|}{ Directional Measures } \\
\hline & & & Value & $\begin{array}{c}\text { Asymp. Std. } \\
\text { Error }^{\mathrm{a}}\end{array}$ & Approx. $\mathrm{T}^{\mathrm{b}}$ & Approx. Sig. \\
\hline \multirow[t]{9}{*}{ Nominal by Nominal } & \multirow[t]{5}{*}{ Lambda } & Symmetric & .185 & .124 & 1.390 & .165 \\
\hline & & Familiarity with & .150 & .142 & .978 & .328 \\
\hline & & Guidelines Dependent & & & & \\
\hline & & Overall Adherence & .220 & .135 & 1.458 & .145 \\
\hline & & Dependent & & & & \\
\hline & \multirow{4}{*}{$\begin{array}{l}\text { Goodman } \\
\text { and } \\
\text { Kruskal tau }\end{array}$} & Familiarity with & \multirow[t]{2}{*}{.080} & \multirow[t]{2}{*}{.048} & & \multirow[t]{2}{*}{$.007^{\mathrm{c}}$} \\
\hline & & Guidelines Dependent & & & & \\
\hline & & Overall Adherence & \multirow[t]{2}{*}{.105} & \multirow[t]{2}{*}{.051} & & \multirow[t]{2}{*}{$.001^{\mathrm{c}}$} \\
\hline & & Dependent & & & & \\
\hline
\end{tabular}

a. Not assuming the null hypothesis.

b. Using the asymptotic standard error assuming the null hypothesis.

c. Based on chi-square approximation

\section{Symmetric Measures}

\begin{tabular}{|ll|r|r|}
\hline & & \multicolumn{1}{|c|}{ Value } & Approx. Sig. \\
\hline Nominal by Nominal & Phi & .352 & .025 \\
& Cramer's V & .249 & .025 \\
& Contingency Coefficient & .332 & .025 \\
N of Valid Cases & & 90 & \\
\hline
\end{tabular}




\section{Appendix J: Category Adherence and Institutional Variables}

\section{Crosstabs}

Notes

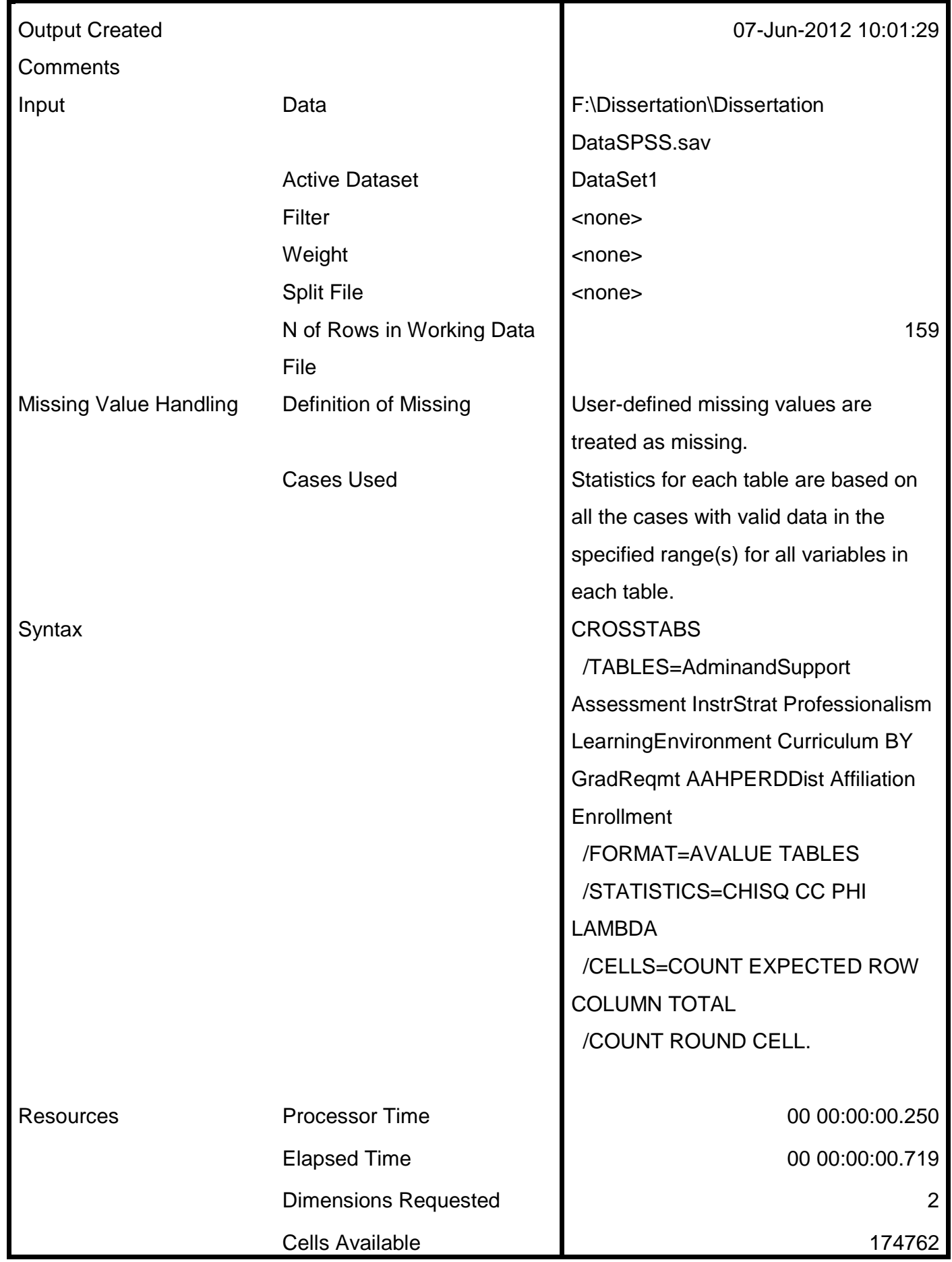


[DataSet1] F:IDissertation\Dissertation DataSPSS.sav

Case Processing Summary

\begin{tabular}{|c|c|c|c|c|c|c|}
\hline & \multicolumn{6}{|c|}{ Cases } \\
\hline & \multicolumn{2}{|c|}{ Valid } & \multicolumn{2}{|c|}{ Missing } & \multicolumn{2}{|c|}{ Total } \\
\hline & $\mathrm{N}$ & Percent & $\mathrm{N}$ & Percent & $\mathrm{N}$ & Percent \\
\hline AdminandSupport * & 71 & $44.7 \%$ & 88 & $55.3 \%$ & 159 & $100.0 \%$ \\
\hline PEGradReq & & & & & & \\
\hline AdminandSupport * & 71 & $44.7 \%$ & 88 & $55.3 \%$ & 159 & $100.0 \%$ \\
\hline AAHPERDDist & & & & & & \\
\hline AdminandSupport * & 71 & $44.7 \%$ & 88 & $55.3 \%$ & 159 & $100.0 \%$ \\
\hline Affiliation & & & & & & \\
\hline AdminandSupport * & 71 & $44.7 \%$ & 88 & $55.3 \%$ & 159 & $100.0 \%$ \\
\hline EnrollmentCondense & & & & & & \\
\hline Assessment * PEGradReq & 90 & $56.6 \%$ & 69 & $43.4 \%$ & 159 & $100.0 \%$ \\
\hline Assessment * & 90 & $56.6 \%$ & 69 & $43.4 \%$ & 159 & $100.0 \%$ \\
\hline AAHPERDDist & & & & & & \\
\hline Assessment * Affiliation & 90 & $56.6 \%$ & 69 & $43.4 \%$ & 159 & $100.0 \%$ \\
\hline Assessment * & 90 & $56.6 \%$ & 69 & $43.4 \%$ & 159 & $100.0 \%$ \\
\hline EnrollmentCondense & & & & & & \\
\hline InstrStrat * PEGradReq & 87 & $54.7 \%$ & 72 & $45.3 \%$ & 159 & $100.0 \%$ \\
\hline InstrStrat * AAHPERDDist & 89 & $56.0 \%$ & 70 & $44.0 \%$ & 159 & $100.0 \%$ \\
\hline InstrStrat * Affiliation & 89 & $56.0 \%$ & 70 & $44.0 \%$ & 159 & $100.0 \%$ \\
\hline InstrStrat * & 89 & $56.0 \%$ & 70 & $44.0 \%$ & 159 & $100.0 \%$ \\
\hline EnrollmentCondense & & & & & & \\
\hline Professionalism * & 87 & $54.7 \%$ & 72 & $45.3 \%$ & 159 & $100.0 \%$ \\
\hline PEGradReq & & & & & & \\
\hline Professionalism * & 89 & $56.0 \%$ & 70 & $44.0 \%$ & 159 & $100.0 \%$ \\
\hline AAHPERDDist & & & & & & \\
\hline Professionalism * Affiliation & 89 & $56.0 \%$ & 70 & $44.0 \%$ & 159 & $100.0 \%$ \\
\hline Professionalism * & 89 & $56.0 \%$ & 70 & $44.0 \%$ & 159 & $100.0 \%$ \\
\hline EnrollmentCondense & & & & & & \\
\hline LearningEnvironment * & 87 & $54.7 \%$ & 72 & $45.3 \%$ & 159 & $100.0 \%$ \\
\hline PEGradReq & & & & & & \\
\hline LearningEnvironment * & 89 & $56.0 \%$ & 70 & $44.0 \%$ & 159 & $100.0 \%$ \\
\hline AAHPERDDist & & & & & & \\
\hline LearningEnvironment * & 89 & $56.0 \%$ & 70 & $44.0 \%$ & 159 & $100.0 \%$ \\
\hline Affiliation & & & & & & \\
\hline LearningEnvironment * & 89 & $56.0 \%$ & 70 & $44.0 \%$ & 159 & $100.0 \%$ \\
\hline EnrollmentCondense & & & & & & \\
\hline
\end{tabular}


ADHERENCE TO INSTRUCTIONAL PRACTICE GUIDELINES 138

\begin{tabular}{|c|c|c|c|c|c|c|}
\hline Curriculum * PEGradReq & 86 & $54.1 \%$ & 73 & $45.9 \%$ & 159 & $100.0 \%$ \\
\hline Curriculum * AAHPERDDist & 88 & $55.3 \%$ & 71 & $44.7 \%$ & 159 & $100.0 \%$ \\
\hline Curriculum * Affiliation & 88 & $55.3 \%$ & 71 & $44.7 \%$ & 159 & $100.0 \%$ \\
\hline Curriculum * & 88 & $55.3 \%$ & 71 & $44.7 \%$ & 159 & $100.0 \%$ \\
\hline EnrollmentCondense & & & & & & \\
\hline
\end{tabular}

\section{AdminandSupport * PEGradReq}

\begin{tabular}{|c|c|c|c|c|c|}
\hline \multicolumn{6}{|c|}{ Crosstab } \\
\hline & & & \multicolumn{2}{|c|}{ PEGradReq } & \multirow[b]{2}{*}{ Total } \\
\hline & & & YES & NO & \\
\hline \multirow[t]{15}{*}{ AdminandSupport } & Not At All & Count & 1 & 2 & 3 \\
\hline & & Expected Count & 1.8 & 1.2 & 3.0 \\
\hline & & $\%$ within AdminandSupport & $33.3 \%$ & $66.7 \%$ & $100.0 \%$ \\
\hline & & $\%$ within PEGradReq & $2.3 \%$ & $7.1 \%$ & $4.2 \%$ \\
\hline & & $\%$ of Total & $1.4 \%$ & $2.8 \%$ & $4.2 \%$ \\
\hline & Partial & Count & 0 & 2 & 2 \\
\hline & & Expected Count & 1.2 & .8 & 2.0 \\
\hline & & \% within AdminandSupport & $.0 \%$ & $100.0 \%$ & $100.0 \%$ \\
\hline & & $\%$ within PEGradReq & $.0 \%$ & $7.1 \%$ & $2.8 \%$ \\
\hline & & $\%$ of Total & $.0 \%$ & $2.8 \%$ & $2.8 \%$ \\
\hline & Fully & Count & 42 & 24 & 66 \\
\hline & & Expected Count & 40.0 & 26.0 & 66.0 \\
\hline & & \% within AdminandSupport & $63.6 \%$ & $36.4 \%$ & $100.0 \%$ \\
\hline & & $\%$ within PEGradReq & $97.7 \%$ & $85.7 \%$ & $93.0 \%$ \\
\hline & & $\%$ of Total & $59.2 \%$ & $33.8 \%$ & $93.0 \%$ \\
\hline \multirow[t]{5}{*}{ Total } & & Count & 43 & 28 & 71 \\
\hline & & Expected Count & 43.0 & 28.0 & 71.0 \\
\hline & & $\%$ within AdminandSupport & $60.6 \%$ & $39.4 \%$ & $100.0 \%$ \\
\hline & & \% within PEGradReq & $100.0 \%$ & $100.0 \%$ & $100.0 \%$ \\
\hline & & $\%$ of Total & $60.6 \%$ & $39.4 \%$ & $100.0 \%$ \\
\hline
\end{tabular}




\section{Chi-Square Tests}

\begin{tabular}{|c|c|c|c|}
\hline & Value & $\mathrm{df}$ & $\begin{array}{c}\text { Asymp. Sig. (2- } \\
\text { sided) }\end{array}$ \\
\hline Pearson Chi-Square & $4.264^{\mathrm{a}}$ & 2 & .119 \\
\hline Likelihood Ratio & 4.891 & 2 & .087 \\
\hline Linear-by-Linear Association & 2.551 & 1 & .110 \\
\hline $\mathrm{N}$ of Valid Cases & 71 & & \\
\hline
\end{tabular}

a. 4 cells $(66.7 \%)$ have expected count less than 5 . The minimum expected count is .79 .

Directional Measures

\begin{tabular}{|c|c|c|c|c|c|c|}
\hline & & & Value & $\begin{array}{c}\text { Asymp. Std. } \\
\text { Error }^{\mathrm{a}}\end{array}$ & Approx. $T^{b}$ & $\begin{array}{c}\text { Approx. } \\
\text { Sig. }\end{array}$ \\
\hline \multirow[t]{7}{*}{ Nominal by Nominal } & \multirow[t]{4}{*}{ Lambda } & Symmetric & .091 & .061 & 1.359 & .174 \\
\hline & & AdminandSupport & .000 & .000 &.$^{\mathrm{c}}$ & \\
\hline & & Dependent & & & & \\
\hline & & PEGradReq Dependent & .107 & .075 & 1.359 & .174 \\
\hline & \multirow{3}{*}{$\begin{array}{l}\text { Goodman and Kruskal } \\
\text { tau }\end{array}$} & AdminandSupport & .039 & .036 & & $.066^{\mathrm{d}}$ \\
\hline & & Dependent & & & & \\
\hline & & PEGradReq Dependent & .060 & .031 & & $.122^{d}$ \\
\hline
\end{tabular}

a. Not assuming the null hypothesis.

b. Using the asymptotic standard error assuming the null hypothesis.

c. Cannot be computed because the asymptotic standard error equals zero.

d. Based on chi-square approximation

Symmetric Measures

\begin{tabular}{|ll|r|r|}
\hline & & & \\
\hline Nominal by Nominal & Phi & .245 & Value \\
& Cramer's V & .245 & .119 \\
& Contingency Coefficient & .238 & .119 \\
& & .119
\end{tabular}


Symmetric Measures

\begin{tabular}{|ll|r|r|}
\hline & & \multicolumn{1}{|c|}{ Value } & Approx. Sig. \\
\hline Nominal by Nominal & Phi & .245 & .119 \\
& Cramer's V & .245 & .119 \\
& Contingency Coefficient & .238 & .119 \\
N of Valid Cases & & 71 & \\
\hline
\end{tabular}

\section{AdminandSupport * AAHPERDDist}

\begin{tabular}{|c|c|c|c|c|c|c|c|c|c|}
\hline \multicolumn{10}{|c|}{ Crosstab } \\
\hline & & & \multicolumn{6}{|c|}{ AAHPERDDist } & \multirow[b]{2}{*}{ Total } \\
\hline & & & $\begin{array}{c}\text { EASTE } \\
\text { RN } \\
\end{array}$ & $\begin{array}{c}\text { CENTR } \\
\mathrm{AL} \\
\end{array}$ & $\begin{array}{c}\text { MIDW } \\
\text { EST } \\
\end{array}$ & $\begin{array}{c}\text { SOUTHE } \\
\mathrm{RN} \\
\end{array}$ & $\begin{array}{c}\text { SOUTHW } \\
\text { EST } \\
\end{array}$ & $\begin{array}{c}\text { NORTHW } \\
\text { EST } \\
\end{array}$ & \\
\hline \multirow{21}{*}{$\begin{array}{l}\text { AdminandSu } \\
\text { pport }\end{array}$} & \multirow{7}{*}{$\begin{array}{l}\text { Not At } \\
\text { All }\end{array}$} & Count & 0 & 1 & 1 & 0 & 0 & 1 & 3 \\
\hline & & Expected Count & .2 & .4 & .8 & 1.4 & .1 & .2 & 3.0 \\
\hline & & $\%$ within & $.0 \%$ & $33.3 \%$ & $33.3 \%$ & $.0 \%$ & $.0 \%$ & $33.3 \%$ & 100.0 \\
\hline & & AdminandSupport & & & & & & & $\%$ \\
\hline & & $\%$ within & $.0 \%$ & $11.1 \%$ & $5.6 \%$ & $.0 \%$ & $.0 \%$ & $20.0 \%$ & $4.2 \%$ \\
\hline & & AAHPERDDist & & & & & & & \\
\hline & & $\%$ of Total & $.0 \%$ & $1.4 \%$ & $1.4 \%$ & $.0 \%$ & $.0 \%$ & $1.4 \%$ & $4.2 \%$ \\
\hline & \multirow[t]{7}{*}{ Partial } & Count & 0 & 0 & 0 & 1 & 0 & 2 & 3 \\
\hline & & Expected Count & .2 & .4 & .8 & 1.4 & .1 & .2 & 3.0 \\
\hline & & $\%$ within & $.0 \%$ & $.0 \%$ & $.0 \%$ & $33.3 \%$ & $.0 \%$ & $66.7 \%$ & 100.0 \\
\hline & & AdminandSupport & & & & & & & $\%$ \\
\hline & & $\%$ within & $.0 \%$ & $.0 \%$ & $.0 \%$ & $3.1 \%$ & $.0 \%$ & $40.0 \%$ & $4.2 \%$ \\
\hline & & AAHPERDDist & & & & & & & \\
\hline & & $\%$ of Total & $.0 \%$ & $.0 \%$ & $.0 \%$ & $1.4 \%$ & $.0 \%$ & $2.8 \%$ & $4.2 \%$ \\
\hline & \multirow[t]{7}{*}{ Fully } & Count & 4 & 8 & 17 & 31 & 3 & 2 & 65 \\
\hline & & Expected Count & 3.7 & 8.2 & 16.5 & 29.3 & 2.7 & 4.6 & 65.0 \\
\hline & & $\%$ within & $6.2 \%$ & $12.3 \%$ & $26.2 \%$ & $47.7 \%$ & $4.6 \%$ & $3.1 \%$ & 100.0 \\
\hline & & AdminandSupport & & & & & & & $\%$ \\
\hline & & $\%$ within & $100.0 \%$ & $88.9 \%$ & $94.4 \%$ & $96.9 \%$ & $100.0 \%$ & $40.0 \%$ & $91.5 \%$ \\
\hline & & AAHPERDDist & & & & & & & \\
\hline & & $\%$ of Total & $5.6 \%$ & $11.3 \%$ & $23.9 \%$ & $43.7 \%$ & $4.2 \%$ & $2.8 \%$ & $91.5 \%$ \\
\hline Total & & Count & 4 & 9 & 18 & 32 & 3 & 5 & 71 \\
\hline
\end{tabular}


ADHERENCE TO INSTRUCTIONAL PRACTICE GUIDELINES 141

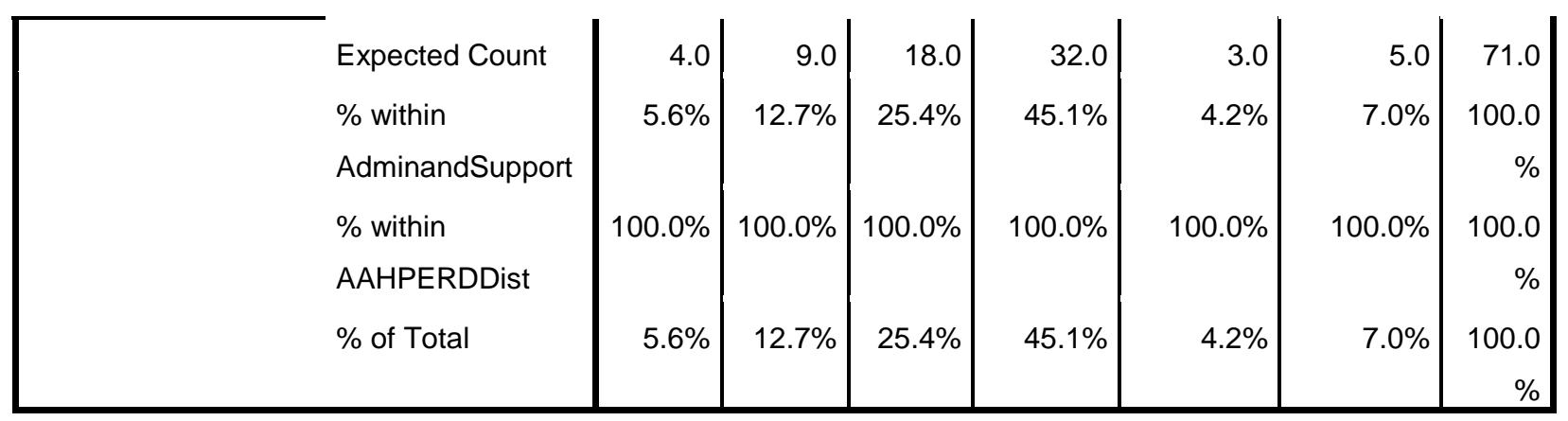

Chi-Square Tests

\begin{tabular}{|l|r|r|r|}
\hline & \multicolumn{1}{|c|}{ Value } & \multicolumn{1}{c|}{ df } & \multicolumn{1}{c|}{$\begin{array}{c}\text { Asymp. Sig. (2- } \\
\text { sided) }\end{array}$} \\
\hline Pearson Chi-Square & $23.979^{\mathrm{a}}$ & 10 & .008 \\
Likelihood Ratio & 15.995 & 10 & .100 \\
Linear-by-Linear Association & 2.186 & 1 & .139 \\
N of Valid Cases & 71 & & \\
\hline
\end{tabular}

a. 15 cells (83.3\%) have expected count less than 5 . The minimum expected count is 13 .

Directional Measures

\begin{tabular}{|c|c|c|c|c|c|c|}
\hline & & & Value & $\begin{array}{c}\text { Asymp. Std. } \\
\text { Error }^{\mathrm{a}}\end{array}$ & $\begin{array}{c}\text { Approx. } \\
\mathrm{T}^{\mathrm{b}}\end{array}$ & $\begin{array}{c}\text { Approx. } \\
\text { Sig. }\end{array}$ \\
\hline \multirow{9}{*}{$\begin{array}{l}\text { Nominal by } \\
\text { Nominal }\end{array}$} & \multirow[t]{5}{*}{ Lambda } & Symmetric & .044 & .075 & .579 & .563 \\
\hline & & AdminandSupport & .000 & .333 & .000 & 1.000 \\
\hline & & Dependent & & & & \\
\hline & & AAHPERDDist & .051 & .050 & 1.007 & .314 \\
\hline & & Dependent & & & & \\
\hline & \multirow{4}{*}{$\begin{array}{l}\text { Goodman and Kruskal } \\
\text { tau }\end{array}$} & AdminandSupport & \multirow[t]{4}{*}{.217} & \multirow[t]{4}{*}{.137} & & \multirow[t]{4}{*}{$.001^{\circ}$} \\
\hline & & Dependent & & & & \\
\hline & & AAHPERDDist & & & & \\
\hline & & Dependent & & & & \\
\hline
\end{tabular}


Directional Measures

\begin{tabular}{|c|c|c|c|c|c|c|}
\hline & & & Value & $\begin{array}{c}\text { Asymp. Std. } \\
\text { Error }^{a}\end{array}$ & $\begin{array}{l}\text { Approx. } \\
\mathrm{T}^{\mathrm{b}}\end{array}$ & $\begin{array}{l}\text { Approx. } \\
\text { Sig. }\end{array}$ \\
\hline \multirow{9}{*}{$\begin{array}{l}\text { Nominal by } \\
\text { Nominal }\end{array}$} & \multirow[t]{5}{*}{ Lambda } & Symmetric & .044 & .075 & .579 & .563 \\
\hline & & AdminandSupport & .000 & .333 & .000 & 1.000 \\
\hline & & Dependent & & & & \\
\hline & & AAHPERDDist & .051 & .050 & 1.007 & .314 \\
\hline & & Dependent & & & & \\
\hline & \multirow{4}{*}{$\begin{array}{l}\text { Goodman and Kruskal } \\
\text { tau }\end{array}$} & AdminandSupport & \multirow[t]{2}{*}{.217} & \multirow[t]{2}{*}{.137} & & \multirow[t]{2}{*}{$.001^{\mathrm{c}}$} \\
\hline & & Dependent & & & & \\
\hline & & AAHPERDDist & \multirow[t]{2}{*}{.050} & \multirow[t]{2}{*}{.024} & & \multirow[t]{2}{*}{$.066^{\circ}$} \\
\hline & & Dependent & & & & \\
\hline
\end{tabular}

a. Not assuming the null hypothesis.

b. Using the asymptotic standard error assuming the null hypothesis.

c. Based on chi-square approximation

Symmetric Measures

\begin{tabular}{|ll|r|r|}
\hline & & Value & Approx. Sig. \\
\hline Nominal by Nominal & Phi & .581 & .008 \\
& Cramer's V & .411 & .008 \\
& Contingency Coefficient & .502 & .008 \\
N of Valid Cases & & 71 & \\
\hline
\end{tabular}

\section{AdminandSupport * Affiliation}

\begin{tabular}{|c|c|c|c|c|c|}
\hline \multicolumn{6}{|c|}{ Crosstab } \\
\hline & & & \multicolumn{2}{|c|}{ Affiliation } & \multirow[b]{2}{*}{ Total } \\
\hline & & & PUBLIC & PRIVATE & \\
\hline \multirow[t]{5}{*}{ AdminandSupport } & Not At All & Count & 2 & 1 & 3 \\
\hline & & Expected Count & 1.6 & 1.4 & 3.0 \\
\hline & & $\%$ within AdminandSupport & $66.7 \%$ & $33.3 \%$ & $100.0 \%$ \\
\hline & & $\%$ within Affiliation & $5.1 \%$ & $3.1 \%$ & $4.2 \%$ \\
\hline & & $\%$ of Total & $2.8 \%$ & $1.4 \%$ & $4.2 \%$ \\
\hline
\end{tabular}


ADHERENCE TO INSTRUCTIONAL PRACTICE GUIDELINES 143

\begin{tabular}{|c|c|c|c|c|c|}
\hline & Partial & $\begin{array}{l}\text { Count } \\
\text { Expected Count } \\
\% \text { within AdminandSupport } \\
\% \text { within Affiliation } \\
\% \text { of Total }\end{array}$ & $\begin{array}{r}3 \\
1.6 \\
100.0 \% \\
7.7 \% \\
4.2 \% \\
\end{array}$ & $\begin{array}{r}0 \\
1.4 \\
.0 \% \\
.0 \% \\
.0 \% \\
\end{array}$ & $\begin{array}{r}3 \\
3.0 \\
100.0 \% \\
4.2 \% \\
4.2 \% \\
\end{array}$ \\
\hline & Fully & $\begin{array}{l}\text { Count } \\
\text { Expected Count } \\
\% \text { within AdminandSupport } \\
\% \text { within Affiliation } \\
\% \text { of Total }\end{array}$ & $\begin{array}{r}34 \\
35.7 \\
52.3 \% \\
87.2 \% \\
47.9 \% \\
\end{array}$ & $\begin{array}{r}31 \\
29.3 \\
47.7 \% \\
96.9 \% \\
43.7 \% \\
\end{array}$ & $\begin{array}{r}65 \\
65.0 \\
100.0 \% \\
91.5 \% \\
91.5 \% \\
\end{array}$ \\
\hline Total & & $\begin{array}{l}\text { Count } \\
\text { Expected Count } \\
\% \text { within AdminandSupport } \\
\% \text { within Affiliation } \\
\% \text { of Total }\end{array}$ & $\begin{array}{r}39 \\
39.0 \\
54.9 \% \\
100.0 \% \\
54.9 \%\end{array}$ & $\begin{array}{r}32 \\
32.0 \\
45.1 \% \\
100.0 \% \\
45.1 \%\end{array}$ & $\begin{array}{r}71 \\
71.0 \\
100.0 \% \\
100.0 \% \\
100.0 \%\end{array}$ \\
\hline
\end{tabular}

\section{Chi-Square Tests}

\begin{tabular}{|l|r|r|r|}
\hline & Value & df & \multicolumn{2}{|c|}{$\begin{array}{c}\text { Asymp. Sig. (2- } \\
\text { sided) }\end{array}$} \\
\hline Pearson Chi-Square & $2.809^{\mathrm{a}}$ & 2 & .245 \\
Likelihood Ratio & 3.946 & 2 & .139 \\
Linear-by-Linear Association & 1.215 & 1 & .270 \\
N of Valid Cases & 71 & & \\
\hline
\end{tabular}

a. 4 cells $(66.7 \%)$ have expected count less than 5 . The minimum expected count is 1.35 .

Directional Measures

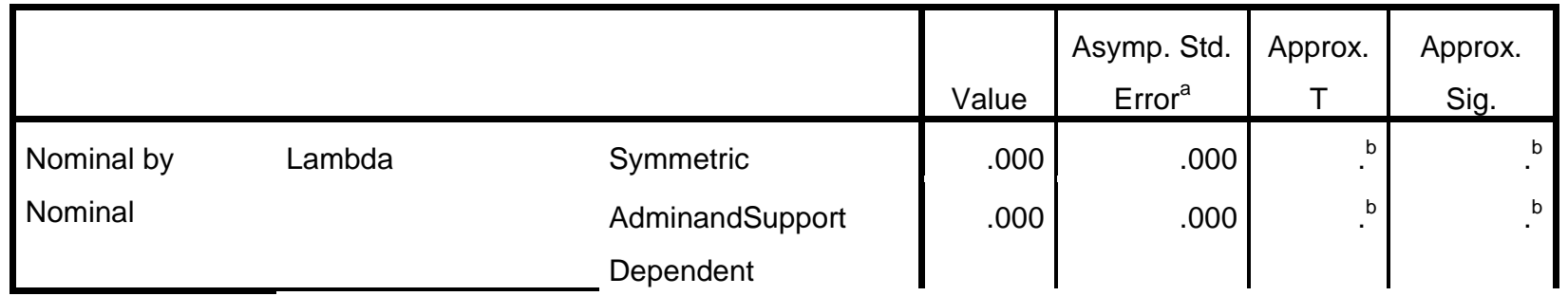


ADHERENCE TO INSTRUCTIONAL PRACTICE GUIDELINES 144

\begin{tabular}{|c|c|c|c|c|c|}
\hline & Affiliation Dependent & .000 & .000 & b & . \\
\hline $\begin{array}{l}\text { Goodman and Kruskal } \\
\text { tau }\end{array}$ & $\begin{array}{l}\text { AdminandSupport } \\
\text { Dependent }\end{array}$ & .025 & .023 & & $.179^{c}$ \\
\hline & Affiliation Dependent & .040 & .016 & & $.250^{\mathrm{c}}$ \\
\hline
\end{tabular}

a. Not assuming the null hypothesis.

b. Cannot be computed because the asymptotic standard error equals zero.

c. Based on chi-square approximation

Symmetric Measures

\begin{tabular}{|ll|r|r|}
\hline & & \multicolumn{1}{|c|}{ Value } & Approx. Sig. \\
\hline Nominal by Nominal & Phi & .199 & .245 \\
& Cramer's V & .199 & .245 \\
& Contingency Coefficient & .195 & .245 \\
N of Valid Cases & & 71 & \\
\hline
\end{tabular}

\section{AdminandSupport * EnrollmentCondense}

\begin{tabular}{|c|c|c|c|c|c|c|}
\hline \multicolumn{7}{|c|}{ Crosstab } \\
\hline & & & \multicolumn{3}{|c|}{ EnrollmentCondense } & \multirow[b]{2}{*}{ Total } \\
\hline & & & $\begin{array}{c}\text { Small (500- } \\
2500) \\
\end{array}$ & $\begin{array}{c}\text { Medium } \\
(2501-10000) \\
\end{array}$ & $\begin{array}{c}\text { Large } \\
(>10,000) \\
\end{array}$ & \\
\hline \multirow{11}{*}{$\begin{array}{l}\text { AdminandSuppor } \\
\text { t }\end{array}$} & Not At All & Count & 1 & 0 & 2 & 3 \\
\hline & & Expected Count & 1.3 & 1.0 & .8 & 3.0 \\
\hline & & $\%$ within & $33.3 \%$ & $.0 \%$ & $66.7 \%$ & $100.0 \%$ \\
\hline & & AdminandSupport & & & & \\
\hline & & $\%$ within & $3.3 \%$ & $.0 \%$ & $11.1 \%$ & $4.2 \%$ \\
\hline & & EnrollmentCondense & & & & \\
\hline & & $\%$ of Total & $1.4 \%$ & $.0 \%$ & $2.8 \%$ & $4.2 \%$ \\
\hline & Partial & Count & 1 & 0 & 2 & 3 \\
\hline & & Expected Count & 1.3 & 1.0 & .8 & 3.0 \\
\hline & & $\%$ within & $33.3 \%$ & $.0 \%$ & $66.7 \%$ & $100.0 \%$ \\
\hline & & AdminandSupport & & & & \\
\hline
\end{tabular}


ADHERENCE TO INSTRUCTIONAL PRACTICE GUIDELINES 145

\begin{tabular}{|c|c|c|c|c|c|c|}
\hline & & $\begin{array}{l}\% \text { within } \\
\text { EnrollmentCondense } \\
\% \text { of Total }\end{array}$ & $\begin{array}{r}3.3 \% \\
1.4 \% \\
\end{array}$ & $.0 \%$ & $11.1 \%$ & $4.2 \%$ \\
\hline & Fully & Count & 28 & 23 & 14 & 65 \\
\hline & & Expected Count & 27.5 & 21.1 & 16.5 & 65.0 \\
\hline & & \% within & $43.1 \%$ & $35.4 \%$ & $21.5 \%$ & $100.0 \%$ \\
\hline & & AdminandSupport & & & & \\
\hline & & $\%$ within & $93.3 \%$ & $100.0 \%$ & $77.8 \%$ & $91.5 \%$ \\
\hline & & EnrollmentCondense & & & & \\
\hline & & $\%$ of Total & $39.4 \%$ & $32.4 \%$ & $19.7 \%$ & $91.5 \%$ \\
\hline Total & & Count & 30 & 23 & 18 & 71 \\
\hline & & Expected Count & 30.0 & 23.0 & 18.0 & 71.0 \\
\hline & & $\%$ within & $42.3 \%$ & $32.4 \%$ & $25.4 \%$ & $100.0 \%$ \\
\hline & & AdminandSupport & & & & \\
\hline & & \% within & $100.0 \%$ & $100.0 \%$ & $100.0 \%$ & $100.0 \%$ \\
\hline & & EnrollmentCondense & & & & \\
\hline & & $\%$ of Total & $42.3 \%$ & $32.4 \%$ & $25.4 \%$ & $100.0 \%$ \\
\hline
\end{tabular}

\section{Chi-Square Tests}

\begin{tabular}{|l|r|r|r|}
\hline & Value & df & \multicolumn{1}{c|}{$\begin{array}{c}\text { Asymp. Sig. (2- } \\
\text { sided) }\end{array}$} \\
\hline Pearson Chi-Square & $6.659^{\mathrm{a}}$ & 4 & .155 \\
Likelihood Ratio & 7.364 & 4 & .118 \\
Linear-by-Linear Association & 2.246 & 1 & .134 \\
N of Valid Cases & 71 & & \\
\hline
\end{tabular}

a. 6 cells $(66.7 \%)$ have expected count less than 5 . The minimum expected count is .76 .

Directional Measures

\begin{tabular}{|lc|r|r|r|r|}
\hline & & Asymp. Std. \\
Error $^{\mathrm{a}}$ & \multicolumn{1}{|c|}{$\begin{array}{c}\text { Approx. } \\
\mathrm{T}^{\mathrm{b}}\end{array}$} & $\begin{array}{c}\text { Approx. } \\
\text { Sig. }\end{array}$ \\
\hline Nominal by Lambda & Symmetric & .043 & .050 & .820 & .412
\end{tabular}


ADHERENCE TO INSTRUCTIONAL PRACTICE GUIDELINES 146

\begin{tabular}{|c|c|c|c|c|c|c|}
\hline \multirow[t]{2}{*}{ Nominal } & & $\begin{array}{l}\text { AdminandSupport } \\
\text { Dependent } \\
\text { EnrollmentCondense } \\
\text { Dependent }\end{array}$ & $\begin{array}{l}.000 \\
.049\end{array}$ & $\begin{array}{l}.000 \\
.058\end{array}$ & $\begin{array}{r}.^{\mathrm{c}} \\
.820\end{array}$ & $\begin{array}{r}.^{\mathrm{c}} \\
.412\end{array}$ \\
\hline & $\begin{array}{l}\text { Goodman and Kruskal } \\
\text { tau }\end{array}$ & $\begin{array}{l}\text { AdminandSupport } \\
\text { Dependent } \\
\text { EnrollmentCondense } \\
\text { Dependent }\end{array}$ & $\begin{array}{l}.069 \\
.040\end{array}$ & $\begin{array}{l}.051 \\
.026\end{array}$ & & $\begin{array}{l}.047^{d} \\
.229^{d}\end{array}$ \\
\hline
\end{tabular}

a. Not assuming the null hypothesis.

b. Using the asymptotic standard error assuming the null hypothesis.

c. Cannot be computed because the asymptotic standard error equals zero.

d. Based on chi-square approximation

\section{Symmetric Measures}

\begin{tabular}{|ll|r|r|}
\hline & & Value & Approx. Sig. \\
\hline Nominal by Nominal & Phi & .306 & .155 \\
& Cramer's V & .217 & .155 \\
& Contingency Coefficient & .293 & .155 \\
N of Valid Cases & & 71 & \\
\hline
\end{tabular}

\section{Assessment * PEGradReq}

Crosstab

\begin{tabular}{|c|c|c|c|c|c|}
\hline \multicolumn{5}{|c|}{ PEGradReq } & \multirow[b]{2}{*}{ Total } \\
\hline & & & YES & $\mathrm{NO}$ & \\
\hline \multirow[t]{8}{*}{ Assessment } & \multirow[t]{5}{*}{ Not at All } & Count & 1 & 0 & 1 \\
\hline & & Expected Count & .6 & .4 & 1.0 \\
\hline & & $\%$ within Assessment & $100.0 \%$ & $.0 \%$ & $100.0 \%$ \\
\hline & & $\%$ within PEGradReq & $1.8 \%$ & $.0 \%$ & $1.1 \%$ \\
\hline & & $\%$ of Total & $1.1 \%$ & $.0 \%$ & $1.1 \%$ \\
\hline & \multirow[t]{3}{*}{ Partial } & Count & 29 & 25 & 54 \\
\hline & & Expected Count & 33.0 & 21.0 & 54.0 \\
\hline & & $\%$ within Assessment & $53.7 \%$ & $46.3 \%$ & $100.0 \%$ \\
\hline
\end{tabular}


ADHERENCE TO INSTRUCTIONAL PRACTICE GUIDELINES 147

\begin{tabular}{|c|c|c|c|c|c|}
\hline & & $\begin{array}{l}\% \text { within PEGradReq } \\
\% \text { of Total }\end{array}$ & $\begin{array}{l}52.7 \% \\
32.2 \% \\
\end{array}$ & $\begin{array}{l}71.4 \% \\
27.8 \% \\
\end{array}$ & $\begin{array}{l}60.0 \% \\
60.0 \% \\
\end{array}$ \\
\hline & Fully & Count & 25 & 10 & 35 \\
\hline & & Expected Count & 21.4 & 13.6 & 35.0 \\
\hline & & $\%$ within Assessment & $71.4 \%$ & $28.6 \%$ & $100.0 \%$ \\
\hline & & $\%$ within PEGradReq & $45.5 \%$ & $28.6 \%$ & $38.9 \%$ \\
\hline & & $\%$ of Total & $27.8 \%$ & $11.1 \%$ & $38.9 \%$ \\
\hline Total & & Count & 55 & 35 & 90 \\
\hline & & Expected Count & 55.0 & 35.0 & 90.0 \\
\hline & & $\%$ within Assessment & $61.1 \%$ & $38.9 \%$ & $100.0 \%$ \\
\hline & & $\%$ within PEGradReq & $100.0 \%$ & $100.0 \%$ & $100.0 \%$ \\
\hline & & $\%$ of Total & $61.1 \%$ & $38.9 \%$ & $100.0 \%$ \\
\hline
\end{tabular}

\section{Chi-Square Tests}

\begin{tabular}{|l|r|r|r|}
\hline & & & $\begin{array}{c}\text { Asymp. Sig. (2- } \\
\text { sided) }\end{array}$ \\
\hline Pearson Chi-Square & $3.451^{\mathrm{a}}$ & $\mathrm{df}$ & .178 \\
Likelihood Ratio & 3.843 & 2 & .146 \\
Linear-by-Linear Association & 1.866 & 1 & .172 \\
N of Valid Cases & 90 & & \\
\hline
\end{tabular}

a. 2 cells (33.3\%) have expected count less than 5 . The minimum expected count is 39 .

Directional Measures

\begin{tabular}{|c|c|c|c|c|c|c|}
\hline & & & Value & $\begin{array}{l}\text { Asymp. Std. } \\
\text { Error }^{\mathrm{a}}\end{array}$ & Approx. T & Approx. Sig. \\
\hline \multirow[t]{5}{*}{ Nominal by Nominal } & Lambda & Symmetric & .000 & .000 &. $\mathrm{~b}$ &. \\
\hline & & Assessment Dependent & .000 & .000 &. &. \\
\hline & & PEGradReq Dependent & .000 & .000 &. &. \\
\hline & $\begin{array}{l}\text { Goodman and Kruskal } \\
\text { tau }\end{array}$ & Assessment Dependent & .031 & .035 & & $.063^{\mathrm{c}}$ \\
\hline & & PEGradReq Dependent & .038 & .036 & & $.182^{\mathrm{c}}$ \\
\hline
\end{tabular}


Directional Measures

\begin{tabular}{|c|c|c|c|c|c|c|}
\hline & & & Value & $\begin{array}{c}\text { Asymp. Std. } \\
\text { Error }^{\mathrm{a}}\end{array}$ & Approx. T & Approx. Sig. \\
\hline \multirow[t]{5}{*}{ Nominal by Nominal } & Lambda & Symmetric & .000 & .000 & b &.$^{b}$ \\
\hline & & Assessment Dependent & .000 & .000 & b & b \\
\hline & & PEGradReq Dependent & .000 & .000 &. $\mathrm{~b}$ &. $\mathrm{~b}$ \\
\hline & $\begin{array}{l}\text { Goodman and Kruskal } \\
\text { tau }\end{array}$ & Assessment Dependent & .031 & .035 & & $.063^{\mathrm{c}}$ \\
\hline & & PEGradReq Dependent & .038 & .036 & & $.182^{\mathrm{c}}$ \\
\hline
\end{tabular}

a. Not assuming the null hypothesis.

b. Cannot be computed because the asymptotic standard error equals zero.

c. Based on chi-square approximation

\section{Symmetric Measures}

\begin{tabular}{|ll|r|r|}
\hline & & \multicolumn{1}{|c|}{ Value } & Approx. Sig. \\
\hline Nominal by Nominal & Phi & .196 & .178 \\
& Cramer's V & .196 & .178 \\
& Contingency Coefficient & .192 & .178 \\
N of Valid Cases & & 90 & \\
\hline
\end{tabular}

\section{Assessment * AAHPERDDist}

\begin{tabular}{|c|c|c|c|c|c|c|c|c|c|}
\hline \multicolumn{10}{|c|}{ Crosstab } \\
\hline & & & \multicolumn{6}{|c|}{ AAHPERDDist } & \multirow[b]{2}{*}{ Total } \\
\hline & & & $\begin{array}{c}\text { EASTE } \\
\text { RN } \\
\end{array}$ & $\begin{array}{c}\text { CENTR } \\
\mathrm{AL} \\
\end{array}$ & $\begin{array}{c}\text { MIDWE } \\
\text { ST } \\
\end{array}$ & $\begin{array}{c}\text { SOUTHE } \\
\text { RN }\end{array}$ & $\begin{array}{c}\text { SOUTHW } \\
\text { EST }\end{array}$ & $\begin{array}{c}\text { NORTHW } \\
\text { EST }\end{array}$ & \\
\hline \multirow{7}{*}{$\begin{array}{l}\text { Assessm } \\
\text { ent }\end{array}$} & Not at & Count & 0 & 0 & 0 & 0 & 0 & 1 & 1 \\
\hline & All & Expected Count & .0 & .2 & .2 & .4 & .1 & .1 & 1.0 \\
\hline & & $\%$ within & $.0 \%$ & $.0 \%$ & $.0 \%$ & $.0 \%$ & $.0 \%$ & $100.0 \%$ & 100.0 \\
\hline & & Assessment & & & & & & & $\%$ \\
\hline & & $\%$ within & $.0 \%$ & $.0 \%$ & $.0 \%$ & $.0 \%$ & $.0 \%$ & $14.3 \%$ & $1.1 \%$ \\
\hline & & AAHPERDDist & & & & & & & \\
\hline & & $\%$ of Total & $.0 \%$ & $.0 \%$ & $.0 \%$ & $.0 \%$ & $.0 \%$ & $1.1 \%$ & $1.1 \%$ \\
\hline
\end{tabular}


ADHERENCE TO INSTRUCTIONAL PRACTICE GUIDELINES 149

\begin{tabular}{|c|c|c|c|c|c|c|c|c|c|}
\hline \multirow{7}{*}{\multicolumn{2}{|c|}{ Partial }} & Count & 1 & 9 & 15 & 19 & 4 & 5 & 53 \\
\hline & & Expected Count & 2.4 & 8.2 & 12.4 & 23.0 & 2.9 & 4.1 & 53.0 \\
\hline & & $\%$ within & $1.9 \%$ & $17.0 \%$ & $28.3 \%$ & $35.8 \%$ & $7.5 \%$ & $9.4 \%$ & 100.0 \\
\hline & & Assessment & & & & & & & $\%$ \\
\hline & & $\%$ within & $25.0 \%$ & $64.3 \%$ & $71.4 \%$ & $48.7 \%$ & $80.0 \%$ & $71.4 \%$ & $58.9 \%$ \\
\hline & & AAHPERDDist & & & & & & & \\
\hline & & $\%$ of Total & $1.1 \%$ & $10.0 \%$ & $16.7 \%$ & $21.1 \%$ & $4.4 \%$ & $5.6 \%$ & $58.9 \%$ \\
\hline & Fully & Count & 3 & 5 & 6 & 20 & 1 & 1 & 36 \\
\hline & & Expected Count & 1.6 & 5.6 & 8.4 & 15.6 & 2.0 & 2.8 & 36.0 \\
\hline & & $\%$ within & $8.3 \%$ & $13.9 \%$ & $16.7 \%$ & $55.6 \%$ & $2.8 \%$ & $2.8 \%$ & 100.0 \\
\hline & & Assessment & & & & & & & \\
\hline & & $\%$ within & $75.0 \%$ & $35.7 \%$ & $28.6 \%$ & $51.3 \%$ & $20.0 \%$ & $14.3 \%$ & $40.0 \%$ \\
\hline & & AAHPERDDist & & & & & & & \\
\hline & & $\%$ of Total & $3.3 \%$ & $5.6 \%$ & $6.7 \%$ & $22.2 \%$ & $1.1 \%$ & $1.1 \%$ & $40.0 \%$ \\
\hline \multirow[t]{8}{*}{ Total } & & Count & 4 & 14 & 21 & 39 & 5 & 7 & 90 \\
\hline & & Expected Count & 4.0 & 14.0 & 21.0 & 39.0 & 5.0 & 7.0 & 90.0 \\
\hline & & $\%$ within & $4.4 \%$ & $15.6 \%$ & $23.3 \%$ & $43.3 \%$ & $5.6 \%$ & $7.8 \%$ & 100.0 \\
\hline & & Assessment & & & & & & & $\%$ \\
\hline & & $\%$ within & $100.0 \%$ & $100.0 \%$ & $100.0 \%$ & $100.0 \%$ & $100.0 \%$ & $100.0 \%$ & 100.0 \\
\hline & & AAHPERDDist & & & & & & & $\%$ \\
\hline & & $\%$ of Total & $4.4 \%$ & $15.6 \%$ & $23.3 \%$ & $43.3 \%$ & $5.6 \%$ & $7.8 \%$ & 100.0 \\
\hline & & & & & & & & & $\%$ \\
\hline
\end{tabular}

Chi-Square Tests

\begin{tabular}{|l|r|r|r|}
\hline & \multicolumn{1}{|c|}{ Value } & df & \multicolumn{1}{c|}{$\begin{array}{c}\text { Asymp. Sig. (2- } \\
\text { sided) }\end{array}$} \\
\hline Pearson Chi-Square & $19.391^{\mathrm{a}}$ & 10 & .036 \\
Likelihood Ratio & 13.034 & 10 & .222 \\
Linear-by-Linear Association & 1.769 & 1 & .183 \\
N of Valid Cases & 90 & & \\
\hline
\end{tabular}

a. 12 cells $(66.7 \%)$ have expected count less than 5 . The minimum expected count is .04 . 
Directional Measures

\begin{tabular}{|c|c|c|c|c|c|c|}
\hline & & & Value & $\begin{array}{c}\text { Asymp. Std. } \\
\text { Error }^{\mathrm{a}}\end{array}$ & Approx. $\mathrm{T}^{\mathrm{b}}$ & $\begin{array}{l}\text { Approx. } \\
\text { Sig. }\end{array}$ \\
\hline \multirow[t]{7}{*}{ Nominal by Nominal } & Lambda & Symmetric & .045 & .073 & .604 & .546 \\
\hline & & Assessment Dependent & .081 & .170 & .458 & .647 \\
\hline & & AAHPERDDist & .020 & .019 & 1.006 & .315 \\
\hline & & Dependent & & & & \\
\hline & Goodman and Kruskal & Assessment Dependent & .082 & .052 & & $.146^{\mathrm{c}}$ \\
\hline & & AAHPERDDist & .039 & .019 & & $.070^{\mathrm{c}}$ \\
\hline & & Dependent & & & & \\
\hline
\end{tabular}

a. Not assuming the null hypothesis.

b. Using the asymptotic standard error assuming the null hypothesis.

c. Based on chi-square approximation

Symmetric Measures

\begin{tabular}{|ll|r|r|}
\hline & & \multicolumn{1}{|c|}{ Value } & Approx. Sig. \\
\hline Nominal by Nominal & Phi & .464 & .036 \\
& Cramer's V & .328 & .036 \\
& Contingency Coefficient & .421 & .036 \\
N of Valid Cases & & 90 & \\
\hline
\end{tabular}

\section{Assessment * Affiliation}

\section{Crosstab}

\begin{tabular}{|c|c|c|c|c|c|}
\hline & & & \multicolumn{2}{|c|}{ Affiliation } & \multirow[b]{2}{*}{ Total } \\
\hline & & & PUBLIC & PRIVATE & \\
\hline \multirow[t]{6}{*}{ Assessment } & Not at All & Count & 0 & 1 & 1 \\
\hline & & Expected Count & .5 & .5 & 1.0 \\
\hline & & $\%$ within Assessment & $.0 \%$ & $100.0 \%$ & $100.0 \%$ \\
\hline & & $\%$ within Affiliation & $.0 \%$ & $2.4 \%$ & $1.1 \%$ \\
\hline & & $\%$ of Total & $.0 \%$ & $1.1 \%$ & $1.1 \%$ \\
\hline & Partial & Count & 28 & 25 & 53 \\
\hline
\end{tabular}


ADHERENCE TO INSTRUCTIONAL PRACTICE GUIDELINES 151

\begin{tabular}{|c|c|c|c|c|c|}
\hline & & Expected Count & 28.9 & 24.1 & 53.0 \\
\hline & & $\%$ within Assessment & $52.8 \%$ & $47.2 \%$ & $100.0 \%$ \\
\hline & & $\%$ within Affiliation & $57.1 \%$ & $61.0 \%$ & $58.9 \%$ \\
\hline & & $\%$ of Total & $31.1 \%$ & $27.8 \%$ & $58.9 \%$ \\
\hline & Fully & Count & 21 & 15 & 36 \\
\hline & & Expected Count & 19.6 & 16.4 & 36.0 \\
\hline & & $\%$ within Assessment & $58.3 \%$ & $41.7 \%$ & $100.0 \%$ \\
\hline & & $\%$ within Affiliation & $42.9 \%$ & $36.6 \%$ & $40.0 \%$ \\
\hline & & $\%$ of Total & $23.3 \%$ & $16.7 \%$ & $40.0 \%$ \\
\hline Total & & Count & 49 & 41 & 90 \\
\hline & & Expected Count & 49.0 & 41.0 & 90.0 \\
\hline & & $\%$ within Assessment & $54.4 \%$ & $45.6 \%$ & $100.0 \%$ \\
\hline & & $\%$ within Affiliation & $100.0 \%$ & $100.0 \%$ & $100.0 \%$ \\
\hline & & $\%$ of Total & $54.4 \%$ & $45.6 \%$ & $100.0 \%$ \\
\hline
\end{tabular}

\section{Chi-Square Tests}

\begin{tabular}{|l|r|r|r|}
\hline & \multicolumn{1}{|c|}{ Value } & df & \multicolumn{1}{c|}{$\begin{array}{c}\text { Asymp. Sig. (2- } \\
\text { sided) }\end{array}$} \\
\hline Pearson Chi-Square & $1.470^{\mathrm{a}}$ & 2 & .479 \\
Likelihood Ratio & 1.849 & 2 & .397 \\
Linear-by-Linear Association & .645 & 1 & .422 \\
N of Valid Cases & 90 & & \\
\hline
\end{tabular}

a. 2 cells $(33.3 \%)$ have expected count less than 5 . The minimum expected count is .46 .

Directional Measures

\begin{tabular}{|c|c|c|c|c|c|c|}
\hline & & & Value & $\begin{array}{c}\text { Asymp. Std. } \\
\text { Error }^{\mathrm{a}}\end{array}$ & Approx. $T^{b}$ & $\begin{array}{c}\text { Approx. } \\
\text { Sig. }\end{array}$ \\
\hline \multirow[t]{4}{*}{ Nominal by Nominal } & Lambda & Symmetric & .013 & .013 & 1.006 & .315 \\
\hline & & Assessment Dependent & .000 & .000 &.$^{\mathrm{c}}$ & c \\
\hline & & Affiliation Dependent & .024 & .024 & 1.006 & .315 \\
\hline & Goodman and Kruskal & Assessment Dependent & .003 & .010 & & $.765^{\mathrm{d}}$ \\
\hline
\end{tabular}


ADHERENCE TO INSTRUCTIONAL PRACTICE GUIDELINES 152

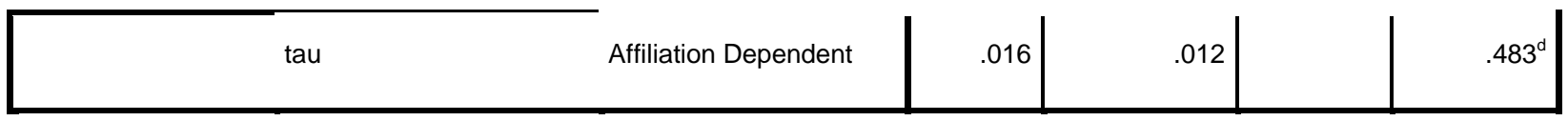

a. Not assuming the null hypothesis.

b. Using the asymptotic standard error assuming the null hypothesis.

c. Cannot be computed because the asymptotic standard error equals zero.

d. Based on chi-square approximation

\section{Symmetric Measures}

\begin{tabular}{|ll|r|r|}
\hline & & \multicolumn{1}{|c|}{ Value } & Approx. Sig. \\
\hline Nominal by Nominal & Phi & .128 & .479 \\
& Cramer's V & .128 & .479 \\
& Contingency Coefficient & .127 & .479 \\
N of Valid Cases & & 90 & \\
& & & \\
\hline
\end{tabular}

\section{Assessment * EnrollmentCondense}

\begin{tabular}{|c|c|c|c|c|c|c|}
\hline \multicolumn{7}{|c|}{ Crosstab } \\
\hline & & & \multicolumn{3}{|c|}{ EnrollmentCondense } & \multirow[b]{2}{*}{ Total } \\
\hline & & & $\begin{array}{c}\text { Small (500- } \\
2500) \\
\end{array}$ & $\begin{array}{c}\text { Medium } \\
(2501-10000) \\
\end{array}$ & $\begin{array}{c}\text { Large } \\
(>10,000) \\
\end{array}$ & \\
\hline \multirow[t]{12}{*}{ Assessment } & \multirow[t]{6}{*}{ Not at All } & Count & 1 & 0 & 0 & 1 \\
\hline & & Expected Count & .4 & .3 & .3 & 1.0 \\
\hline & & $\%$ within Assessment & $100.0 \%$ & $.0 \%$ & $.0 \%$ & $100.0 \%$ \\
\hline & & $\%$ within & $2.6 \%$ & $.0 \%$ & $.0 \%$ & $1.1 \%$ \\
\hline & & EnrollmentCondense & & & & \\
\hline & & $\%$ of Total & $1.1 \%$ & $.0 \%$ & $.0 \%$ & $1.1 \%$ \\
\hline & \multirow[t]{6}{*}{ Partial } & Count & 24 & 12 & 17 & 53 \\
\hline & & Expected Count & 22.4 & 15.9 & 14.7 & 53.0 \\
\hline & & $\%$ within Assessment & $45.3 \%$ & $22.6 \%$ & $32.1 \%$ & $100.0 \%$ \\
\hline & & $\%$ within & $63.2 \%$ & $44.4 \%$ & $68.0 \%$ & $58.9 \%$ \\
\hline & & EnrollmentCondense & & & & \\
\hline & & $\%$ of Total & $26.7 \%$ & $13.3 \%$ & $18.9 \%$ & $58.9 \%$ \\
\hline
\end{tabular}


ADHERENCE TO INSTRUCTIONAL PRACTICE GUIDELINES 153

\begin{tabular}{|c|c|c|c|c|c|c|}
\hline \multirow{6}{*}{\multicolumn{2}{|c|}{$\begin{array}{l}\text { Fully } \\
\text { P }\end{array}$}} & Count & 13 & 15 & 8 & 36 \\
\hline & & Expected Count & 15.2 & 10.8 & 10.0 & 36.0 \\
\hline & & $\%$ within Assessment & $36.1 \%$ & $41.7 \%$ & $22.2 \%$ & $100.0 \%$ \\
\hline & & $\%$ within & $34.2 \%$ & $55.6 \%$ & $32.0 \%$ & $40.0 \%$ \\
\hline & & EnrollmentCondense & & & & \\
\hline & & $\%$ of Total & $14.4 \%$ & $16.7 \%$ & $8.9 \%$ & $40.0 \%$ \\
\hline \multirow{6}{*}{\multicolumn{2}{|c|}{ Total }} & Count & 38 & 27 & 25 & 90 \\
\hline & & Expected Count & 38.0 & 27.0 & 25.0 & 90.0 \\
\hline & & $\%$ within Assessment & $42.2 \%$ & $30.0 \%$ & $27.8 \%$ & $100.0 \%$ \\
\hline & & $\%$ within & $100.0 \%$ & $100.0 \%$ & $100.0 \%$ & $100.0 \%$ \\
\hline & & EnrollmentCondense & & & & \\
\hline & & $\%$ of Total & $42.2 \%$ & $30.0 \%$ & $27.8 \%$ & $100.0 \%$ \\
\hline
\end{tabular}

\section{Chi-Square Tests}

\begin{tabular}{|c|c|c|c|}
\hline & Value & df & $\begin{array}{l}\text { Asymp. Sig. (2- } \\
\text { sided) }\end{array}$ \\
\hline Pearson Chi-Square & $5.147^{\mathrm{a}}$ & 4 & .273 \\
\hline Likelihood Ratio & 5.441 & 4 & .245 \\
\hline Linear-by-Linear Association & .069 & 1 & .792 \\
\hline $\mathrm{N}$ of Valid Cases & 90 & & \\
\hline
\end{tabular}

a. 3 cells $(33.3 \%)$ have expected count less than 5 . The minimum expected count is 28 .

Directional Measures

\begin{tabular}{|c|c|c|c|c|c|c|}
\hline & & & Value & $\begin{array}{c}\text { Asymp. Std. } \\
\text { Error }^{\mathrm{a}}\end{array}$ & $\begin{array}{c}\text { Approx. } \\
\mathrm{T}^{\mathrm{b}}\end{array}$ & $\begin{array}{c}\text { Approx. } \\
\text { Sig. }\end{array}$ \\
\hline \multirow{6}{*}{$\begin{array}{l}\text { Nominal by } \\
\text { Nominal }\end{array}$} & \multirow[t]{5}{*}{ Lambda } & Symmetric & .056 & .101 & .543 & .587 \\
\hline & & Assessment & .081 & .135 & .578 & .563 \\
\hline & & Dependent & & & & \\
\hline & & EnrollmentCondense & .038 & .100 & .378 & .705 \\
\hline & & Dependent & & & & \\
\hline & Goodman and Kruskal & Assessment & .040 & .041 & & $.125^{\mathrm{C}}$ \\
\hline
\end{tabular}


ADHERENCE TO INSTRUCTIONAL PRACTICE GUIDELINES 154

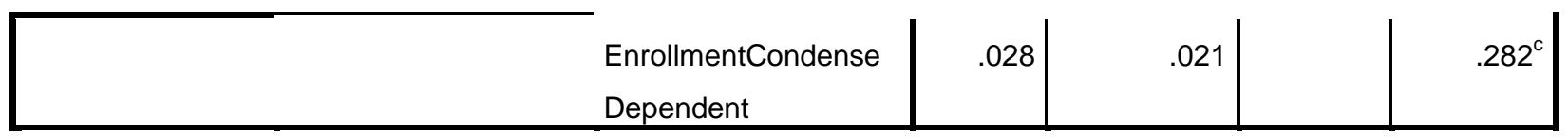

a. Not assuming the null hypothesis.

b. Using the asymptotic standard error assuming the null hypothesis.

c. Based on chi-square approximation

Symmetric Measures

\begin{tabular}{|ll|r|r|}
\hline & & Value & Approx. Sig. \\
\hline Nominal by Nominal & Phi & .239 & .273 \\
& Cramer's V & .169 & .273 \\
& Contingency Coefficient & .233 & .273 \\
N of Valid Cases & & 90 & \\
\hline
\end{tabular}

InstrStrat * PEGradReq

\begin{tabular}{|c|c|c|c|c|c|}
\hline \multicolumn{6}{|c|}{ Crosstab } \\
\hline & & & \multicolumn{2}{|c|}{ PEGradReq } & \multirow[b]{2}{*}{ Total } \\
\hline & & & YES & NO & \\
\hline \multirow[t]{10}{*}{ InstrStrat } & Not at All & Count & 1 & 1 & 2 \\
\hline & & Expected Count & 1.2 & .8 & 2.0 \\
\hline & & $\%$ within InstrStrat & $50.0 \%$ & $50.0 \%$ & $100.0 \%$ \\
\hline & & $\%$ within PEGradReq & $1.9 \%$ & $2.9 \%$ & $2.3 \%$ \\
\hline & & $\%$ of Total & $1.1 \%$ & $1.1 \%$ & $2.3 \%$ \\
\hline & Partial & Count & 52 & 33 & 85 \\
\hline & & Expected Count & 51.8 & 33.2 & 85.0 \\
\hline & & $\%$ within InstrStrat & $61.2 \%$ & $38.8 \%$ & $100.0 \%$ \\
\hline & & $\%$ within PEGradReq & $98.1 \%$ & $97.1 \%$ & $97.7 \%$ \\
\hline & & $\%$ of Total & $59.8 \%$ & $37.9 \%$ & $97.7 \%$ \\
\hline \multirow[t]{4}{*}{ Total } & & Count & 53 & 34 & 87 \\
\hline & & Expected Count & 53.0 & 34.0 & 87.0 \\
\hline & & $\%$ within InstrStrat & $60.9 \%$ & $39.1 \%$ & $100.0 \%$ \\
\hline & & $\%$ within PEGradReq & $100.0 \%$ & $100.0 \%$ & $100.0 \%$ \\
\hline
\end{tabular}




\begin{tabular}{|c|c|c|c|c|c|}
\hline \multicolumn{6}{|c|}{ Crosstab } \\
\hline & & & \multicolumn{2}{|c|}{ PEGradReq } & \multirow[b]{2}{*}{ Total } \\
\hline & & & YES & $\mathrm{NO}$ & \\
\hline \multirow[t]{10}{*}{ InstrStrat } & Not at All & Count & 1 & 1 & 2 \\
\hline & & Expected Count & 1.2 & .8 & 2.0 \\
\hline & & $\%$ within InstrStrat & $50.0 \%$ & $50.0 \%$ & $100.0 \%$ \\
\hline & & $\%$ within PEGradReq & $1.9 \%$ & $2.9 \%$ & $2.3 \%$ \\
\hline & & $\%$ of Total & $1.1 \%$ & $1.1 \%$ & $2.3 \%$ \\
\hline & Partial & Count & 52 & 33 & 85 \\
\hline & & Expected Count & 51.8 & 33.2 & 85.0 \\
\hline & & $\%$ within InstrStrat & $61.2 \%$ & $38.8 \%$ & $100.0 \%$ \\
\hline & & $\%$ within PEGradReq & $98.1 \%$ & $97.1 \%$ & $97.7 \%$ \\
\hline & & $\%$ of Total & $59.8 \%$ & $37.9 \%$ & $97.7 \%$ \\
\hline \multirow[t]{5}{*}{ Total } & & Count & 53 & 34 & 87 \\
\hline & & Expected Count & 53.0 & 34.0 & 87.0 \\
\hline & & $\%$ within InstrStrat & $60.9 \%$ & $39.1 \%$ & $100.0 \%$ \\
\hline & & $\%$ within PEGradReq & $100.0 \%$ & $100.0 \%$ & $100.0 \%$ \\
\hline & & $\%$ of Total & $60.9 \%$ & $39.1 \%$ & $100.0 \%$ \\
\hline
\end{tabular}

Chi-Square Tests

\begin{tabular}{|c|c|c|c|c|c|}
\hline & Value & $\mathrm{df}$ & $\begin{array}{c}\text { Asymp. Sig. (2- } \\
\text { sided) }\end{array}$ & $\begin{array}{c}\text { Exact Sig. (2- } \\
\text { sided) }\end{array}$ & $\begin{array}{c}\text { Exact Sig. (1- } \\
\text { sided) }\end{array}$ \\
\hline Pearson Chi-Square & $.103^{\mathrm{a}}$ & 1 & .749 & & \\
\hline Continuity Correction ${ }^{\mathrm{b}}$ & .000 & 1 & 1.000 & & \\
\hline Likelihood Ratio & .100 & 1 & .752 & & \\
\hline Fisher's Exact Test & & & & 1.000 & .632 \\
\hline Linear-by-Linear Association & .101 & 1 & .750 & & \\
\hline $\mathrm{N}$ of Valid Cases & 87 & & & & \\
\hline
\end{tabular}

a. 2 cells $(50.0 \%)$ have expected count less than 5 . The minimum expected count is .78 .

b. Computed only for a $2 \times 2$ table 
Directional Measures

\begin{tabular}{|c|c|c|c|c|c|c|}
\hline & & & Value & $\begin{array}{c}\text { Asymp. Std. } \\
\text { Error }^{\mathrm{a}}\end{array}$ & $\begin{array}{c}\text { Approx. } \\
\text { T }\end{array}$ & $\begin{array}{l}\text { Approx. } \\
\text { Sig. }\end{array}$ \\
\hline \multirow{7}{*}{$\begin{array}{l}\text { Nominal by } \\
\text { Nominal }\end{array}$} & \multirow[t]{4}{*}{ Lambda } & Symmetric & .000 & .000 &.$^{b}$ & b \\
\hline & & InstrStrat Dependent & .000 & .000 &.$^{b}$ &. $\mathrm{~b}$ \\
\hline & & PEGradReq & .000 & .000 &.$^{b}$ &.$^{b}$ \\
\hline & & Dependent & & & & \\
\hline & \multirow{3}{*}{$\begin{array}{l}\text { Goodman and Kruskal } \\
\text { tau }\end{array}$} & InstrStrat Dependent & .001 & .008 & & $.750^{\mathrm{c}}$ \\
\hline & & PEGradReq & .001 & .008 & & $.750^{\mathrm{c}}$ \\
\hline & & Dependent & & & & \\
\hline
\end{tabular}

a. Not assuming the null hypothesis.

b. Cannot be computed because the asymptotic standard error equals zero.

c. Based on chi-square approximation

Symmetric Measures

\begin{tabular}{|ll|r|r|}
\hline & & Value & Approx. Sig. \\
\hline Nominal by Nominal & Phi & -.034 & .749 \\
& Cramer's V & .034 & .749 \\
& Contingency Coefficient & .034 & .749 \\
N of Valid Cases & & 87 & \\
\hline
\end{tabular}

\section{InstrStrat * AAHPERDDist}

Crosstab

\begin{tabular}{|ll|r|r|r|r|r|r|r|}
\hline & & \multicolumn{7}{|c|}{ AAHPERDDist } \\
\cline { 3 - 8 } & & EASTE & CENTR & MIDWE & SOUTHE & SOUTHW & NORTHW \\
& & RN & AL & ST & RN & EST & EST & Total \\
\hline InstrStr Not at Count & & 0 & 1 & 0 & 0 & 0 & 1 \\
at & All & Expected Count & .1 & .3 & .4 & .9 & .1 & .2 \\
\hline
\end{tabular}


ADHERENCE TO INSTRUCTIONAL PRACTICE GUIDELINES 157

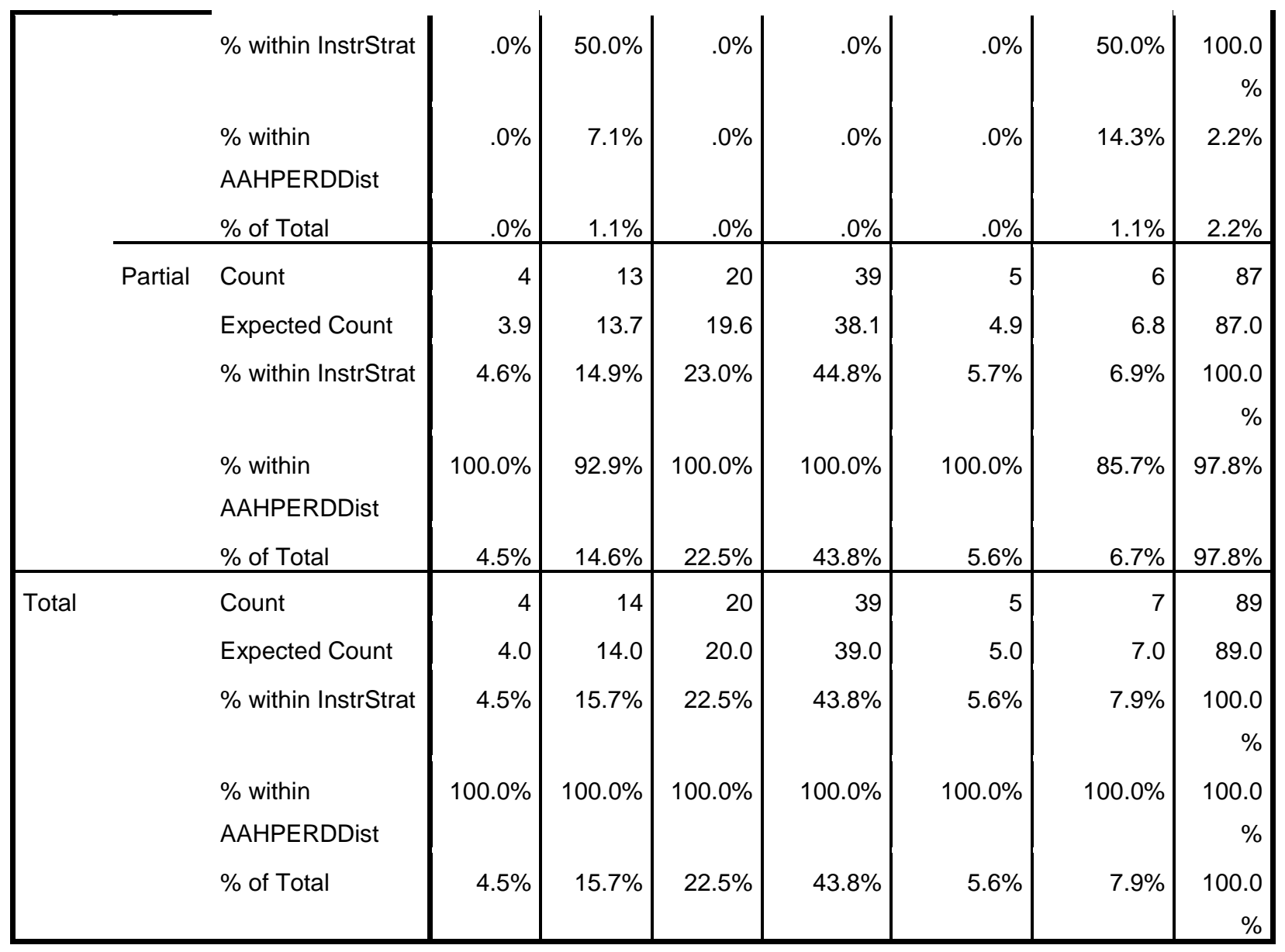

Chi-Square Tests

\begin{tabular}{|c|c|c|c|}
\hline & Value & df & $\begin{array}{c}\text { Asymp. Sig. (2- } \\
\text { sided) }\end{array}$ \\
\hline Pearson Chi-Square & $7.709^{a}$ & 5 & .173 \\
\hline Likelihood Ratio & 6.190 & 5 & .288 \\
\hline Linear-by-Linear Association & .303 & 1 & .582 \\
\hline$N$ of Valid Cases & 89 & & \\
\hline
\end{tabular}

a. 8 cells $(66.7 \%)$ have expected count less than 5 . The minimum expected count is .09 . 
Directional Measures

\begin{tabular}{|c|c|c|c|c|c|c|}
\hline & & & Value & $\begin{array}{c}\text { Asymp. Std. } \\
\text { Error }^{\mathrm{a}}\end{array}$ & $\begin{array}{c}\text { Approx. } \\
\mathrm{T}^{\mathrm{b}}\end{array}$ & $\begin{array}{l}\text { Approx. } \\
\text { Sig. }\end{array}$ \\
\hline \multirow{7}{*}{$\begin{array}{l}\text { Nominal by } \\
\text { Nominal }\end{array}$} & \multirow[t]{4}{*}{ Lambda } & Symmetric & .019 & .019 & 1.006 & .315 \\
\hline & & InstrStrat Dependent & .000 & .000 & &.$^{c}$ \\
\hline & & AAHPERDDist & .020 & .020 & 1.006 & .315 \\
\hline & & Dependent & & & & \\
\hline & \multirow{3}{*}{$\begin{array}{l}\text { Goodman and Kruskal } \\
\text { tau }\end{array}$} & InstrStrat Dependent & \multirow{3}{*}{$\begin{array}{l}.087 \\
.017\end{array}$} & \multirow{3}{*}{$\begin{array}{l}.075 \\
.003\end{array}$} & & \multirow{3}{*}{$\begin{array}{l}.178^{d} \\
.179^{d}\end{array}$} \\
\hline & & AAHPERDDist & & & & \\
\hline & & Dependent & & & & \\
\hline
\end{tabular}

a. Not assuming the null hypothesis.

b. Using the asymptotic standard error assuming the null hypothesis.

c. Cannot be computed because the asymptotic standard error equals zero.

d. Based on chi-square approximation

Symmetric Measures

\begin{tabular}{|ll|r|r|}
\hline & & \multicolumn{1}{|c|}{ Value } & Approx. Sig. \\
\hline Nominal by Nominal & Phi & .294 & .173 \\
& Cramer's V & .294 & .173 \\
& Contingency Coefficient & .282 & .173 \\
N of Valid Cases & & 89 & \\
\hline
\end{tabular}

\section{InstrStrat * Affiliation}

\begin{tabular}{|c|c|c|c|c|c|}
\hline \multicolumn{6}{|c|}{ Crosstab } \\
\hline & & & \multicolumn{2}{|c|}{ Affiliation } & \multirow[b]{2}{*}{ Total } \\
\hline & & & PUBLIC & PRIVATE & \\
\hline \multirow[t]{5}{*}{ InstrStrat } & Not at All & Count & 1 & 1 & 2 \\
\hline & & Expected Count & 1.1 & .9 & 2.0 \\
\hline & & $\%$ within InstrStrat & $50.0 \%$ & $50.0 \%$ & $100.0 \%$ \\
\hline & & $\%$ within Affiliation & $2.0 \%$ & $2.5 \%$ & $2.2 \%$ \\
\hline & & $\%$ of Total & $1.1 \%$ & $1.1 \%$ & $2.2 \%$ \\
\hline
\end{tabular}


ADHERENCE TO INSTRUCTIONAL PRACTICE GUIDELINES 159

\begin{tabular}{|ll|r|r|r|}
\hline Partial & Count & 48 & 39 & 87 \\
& Expected Count & 47.9 & 39.1 & 87.0 \\
& $\%$ within InstrStrat & $55.2 \%$ & $44.8 \%$ & $100.0 \%$ \\
& $\%$ within Affiliation & $98.0 \%$ & $97.5 \%$ & $97.8 \%$ \\
& $\%$ of Total & $53.9 \%$ & $43.8 \%$ & $97.8 \%$ \\
\hline Total & Count & 49 & 40 & 89 \\
& Expected Count & 49.0 & 40.0 & 89.0 \\
& \% within InstrStrat & $55.1 \%$ & $44.9 \%$ & $100.0 \%$ \\
& $\%$ within Affiliation & $100.0 \%$ & $100.0 \%$ & $100.0 \%$ \\
& $\%$ of Total & $55.1 \%$ & $44.9 \%$ & $100.0 \%$ \\
\hline
\end{tabular}

\section{Chi-Square Tests}

\begin{tabular}{|c|c|c|c|c|c|}
\hline & Value & df & $\begin{array}{c}\text { Asymp. Sig. (2- } \\
\text { sided) }\end{array}$ & $\begin{array}{c}\text { Exact Sig. (2- } \\
\text { sided) }\end{array}$ & $\begin{array}{c}\text { Exact Sig. (1- } \\
\text { sided) }\end{array}$ \\
\hline Pearson Chi-Square & $.021^{\mathrm{a}}$ & 1 & .884 & & \\
\hline Continuity Correction $^{\mathrm{b}}$ & .000 & 1 & 1.000 & & \\
\hline Likelihood Ratio & .021 & 1 & .885 & & \\
\hline Fisher's Exact Test & & & & 1.000 & .700 \\
\hline Linear-by-Linear Association & .021 & 1 & .885 & & \\
\hline $\mathrm{N}$ of Valid Cases & 89 & & & & \\
\hline
\end{tabular}

a. 2 cells $(50.0 \%)$ have expected count less than 5 . The minimum expected count is .90 .

b. Computed only for a $2 \times 2$ table

Directional Measures

\begin{tabular}{|c|c|c|c|c|c|c|}
\hline & & & Value & $\begin{array}{c}\text { Asymp. Std. } \\
\text { Error }^{\mathrm{a}}\end{array}$ & $\begin{array}{c}\text { Approx. } \\
\text { T }\end{array}$ & $\begin{array}{c}\text { Approx. } \\
\text { Sig. }\end{array}$ \\
\hline Nominal by & Lambda & Symmetric & .000 & .000 &.$^{b}$ & ${ }^{b}$ \\
\hline Nominal & & $\begin{array}{l}\text { InstrStrat } \\
\text { Dependent }\end{array}$ & .000 & .000 &.$^{\mathrm{b}}$ & ${ }^{b}$ \\
\hline
\end{tabular}


ADHERENCE TO INSTRUCTIONAL PRACTICE GUIDELINES 160

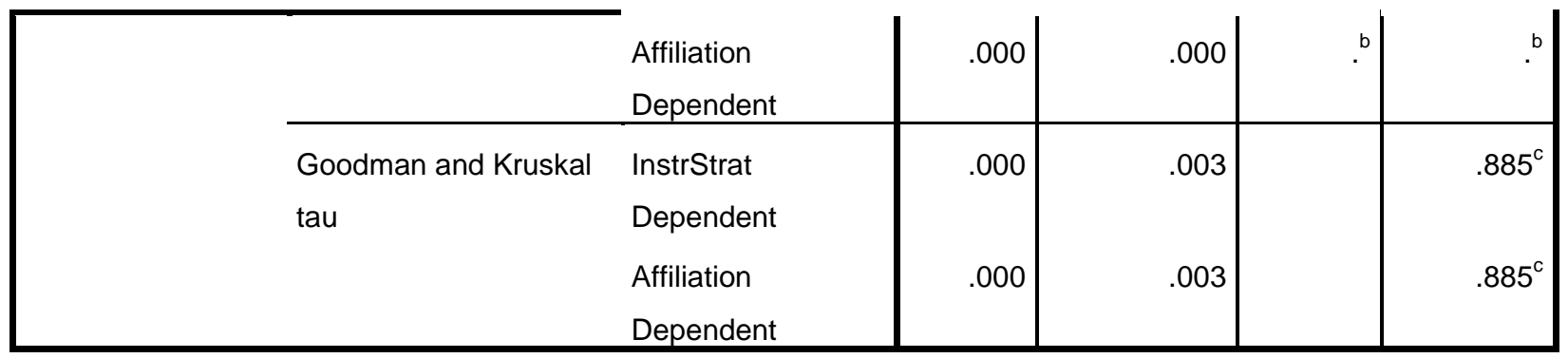

a. Not assuming the null hypothesis.

b. Cannot be computed because the asymptotic standard error equals zero.

c. Based on chi-square approximation

\section{Symmetric Measures}

\begin{tabular}{|ll|r|r|}
\hline & & Value & Approx. Sig. \\
\hline Nominal by Nominal & Phi & -.015 & .884 \\
& Cramer's V & .015 & .884 \\
& Contingency Coefficient & .015 & .884 \\
N of Valid Cases & & 89 & \\
\hline
\end{tabular}

\section{InstrStrat * EnrollmentCondense}

Crosstab

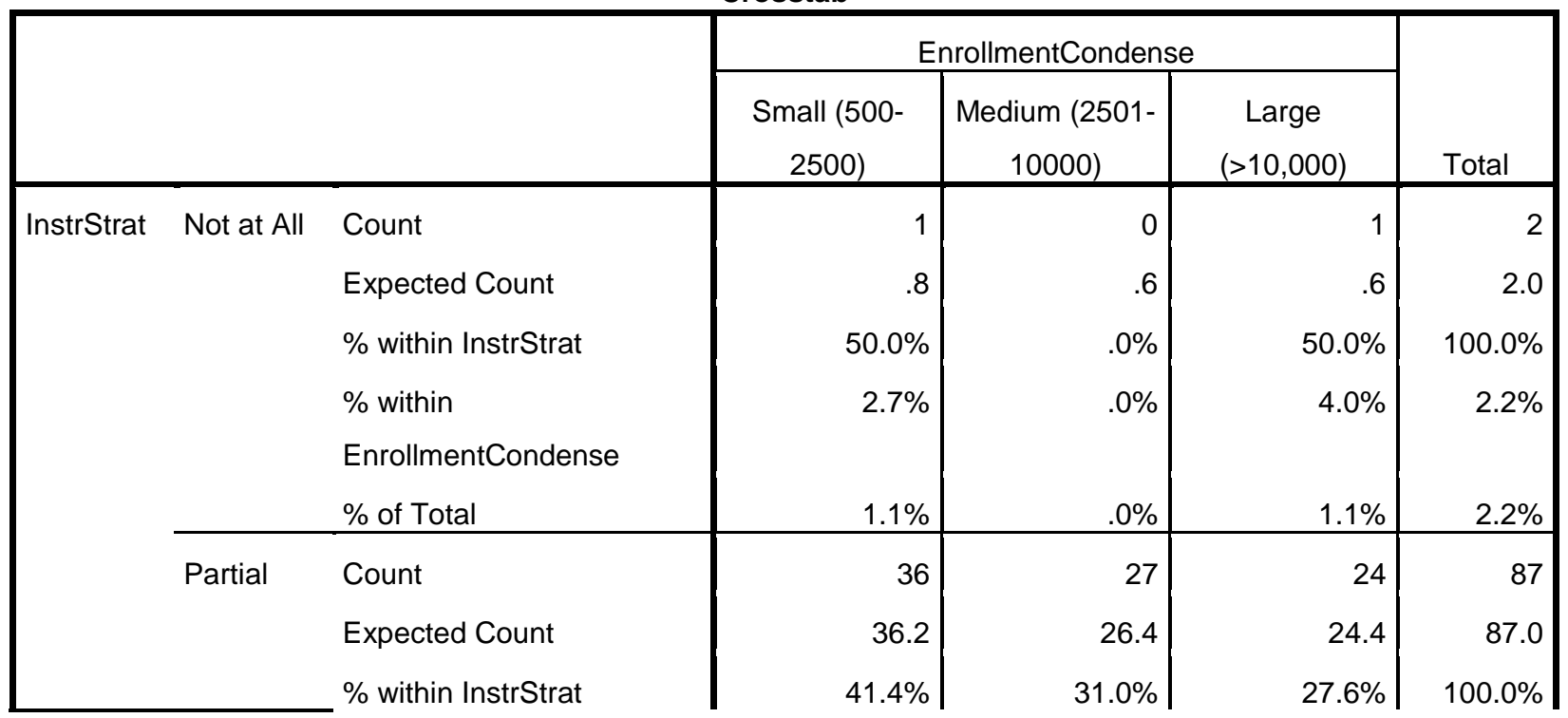


ADHERENCE TO INSTRUCTIONAL PRACTICE GUIDELINES 161

\begin{tabular}{|c|c|c|c|c|c|}
\hline & $\begin{array}{l}\% \text { within } \\
\text { EnrollmentCondense } \\
\% \text { of Total }\end{array}$ & $\begin{array}{l}97.3 \% \\
40.4 \% \\
\end{array}$ & $100.0 \%$ & $96.0 \%$ & $97.8 \%$ \\
\hline \multirow[t]{6}{*}{ Total } & Count & 37 & 27 & 25 & 89 \\
\hline & Expected Count & 37.0 & 27.0 & 25.0 & 89.0 \\
\hline & $\%$ within InstrStrat & $41.6 \%$ & $30.3 \%$ & $28.1 \%$ & $100.0 \%$ \\
\hline & $\%$ within & $100.0 \%$ & $100.0 \%$ & $100.0 \%$ & $100.0 \%$ \\
\hline & EnrollmentCondense & & & & \\
\hline & $\%$ of Total & $41.6 \%$ & $30.3 \%$ & $28.1 \%$ & $100.0 \%$ \\
\hline
\end{tabular}

\section{Chi-Square Tests}

\begin{tabular}{|l|r|r|r|}
\hline & \multicolumn{1}{|c|}{ Value } & df & \multicolumn{1}{c|}{$\begin{array}{c}\text { Asymp. Sig. (2- } \\
\text { sided) }\end{array}$} \\
\hline Pearson Chi-Square & $1.005^{\mathrm{a}}$ & 2 & .605 \\
Likelihood Ratio & 1.545 & 2 & .462 \\
Linear-by-Linear Association & .054 & & .816 \\
N of Valid Cases & 89 & & \\
\hline
\end{tabular}

a. 3 cells $(50.0 \%)$ have expected count less than 5 . The minimum expected count is .56 .

Directional Measures

\begin{tabular}{|c|c|c|c|c|c|c|}
\hline & & & Value & $\begin{array}{c}\text { Asymp. Std. } \\
\text { Error }^{\mathrm{a}}\end{array}$ & Approx. T & $\begin{array}{l}\text { Approx. } \\
\text { Sig. }\end{array}$ \\
\hline \multirow[t]{7}{*}{ Nominal by Nominal } & Lambda & Symmetric & .000 & .000 &. & $b^{b}$ \\
\hline & & InstrStrat Dependent & .000 & .000 &.$^{b}$ &.$^{b}$ \\
\hline & & EnrollmentCondense & .000 & .000 &. &.$^{b}$ \\
\hline & & Dependent & & & & \\
\hline & \multirow{3}{*}{$\begin{array}{l}\text { Goodman and Kruskal } \\
\text { tau }\end{array}$} & InstrStrat Dependent & .011 & .012 & & $.608^{\mathrm{c}}$ \\
\hline & & EnrollmentCondense & .005 & .004 & & $.635^{\mathrm{c}}$ \\
\hline & & Dependent & & & & \\
\hline
\end{tabular}


Directional Measures

\begin{tabular}{|c|c|c|c|c|c|c|}
\hline & & & Value & $\begin{array}{l}\text { Asymp. Std. } \\
\text { Error }^{\mathrm{a}} \\
\end{array}$ & Approx. T & $\begin{array}{l}\text { Approx. } \\
\text { Sig. }\end{array}$ \\
\hline \multirow[t]{7}{*}{ Nominal by Nominal } & Lambda & Symmetric & .000 & .000 &. &.$^{b}$ \\
\hline & & InstrStrat Dependent & .000 & .000 &. & b \\
\hline & & EnrollmentCondense & .000 & .000 &. & b \\
\hline & & Dependent & & & & \\
\hline & \multirow{3}{*}{$\begin{array}{l}\text { Goodman and Kruskal } \\
\text { tau }\end{array}$} & InstrStrat Dependent & .011 & .012 & & $.608^{c}$ \\
\hline & & EnrollmentCondense & .005 & .004 & & $.635^{\mathrm{c}}$ \\
\hline & & Dependent & & & & \\
\hline
\end{tabular}

a. Not assuming the null hypothesis.

b. Cannot be computed because the asymptotic standard error equals zero.

c. Based on chi-square approximation

Symmetric Measures

\begin{tabular}{|ll|r|r|}
\hline & & \multicolumn{1}{|c|}{ Value } & Approx. Sig. \\
\hline Nominal by Nominal & Phi & .106 & .605 \\
& Cramer's V & .106 & .605 \\
& Contingency Coefficient & .106 & .605 \\
N of Valid Cases & & 89 & \\
\hline
\end{tabular}

\section{Professionalism * PEGradReq}

\begin{tabular}{|c|c|c|c|c|c|}
\hline \multicolumn{6}{|c|}{ Crosstab } \\
\hline & & & \multicolumn{2}{|c|}{ PEGradReq } & \multirow[b]{2}{*}{ Total } \\
\hline & & & YES & NO & \\
\hline \multirow[t]{6}{*}{ Professionalism } & Not at All & Count & 2 & 1 & 3 \\
\hline & & Expected Count & 1.8 & 1.2 & 3.0 \\
\hline & & $\%$ within Professionalism & $66.7 \%$ & $33.3 \%$ & $100.0 \%$ \\
\hline & & $\%$ within PEGradReq & $3.8 \%$ & $2.9 \%$ & $3.4 \%$ \\
\hline & & $\%$ of Total & $2.3 \%$ & $1.1 \%$ & $3.4 \%$ \\
\hline & Partial & Count & 9 & 7 & 16 \\
\hline
\end{tabular}


ADHERENCE TO INSTRUCTIONAL PRACTICE GUIDELINES 163

\begin{tabular}{|c|c|c|c|c|c|}
\hline & & Expected Count & 9.7 & 6.3 & 16.0 \\
\hline & & $\%$ within Professionalism & $56.3 \%$ & $43.8 \%$ & $100.0 \%$ \\
\hline & & $\%$ within PEGradReq & $17.0 \%$ & $20.6 \%$ & $18.4 \%$ \\
\hline & & $\%$ of Total & $10.3 \%$ & $8.0 \%$ & $18.4 \%$ \\
\hline & Fully & Count & 42 & 26 & 68 \\
\hline & & Expected Count & 41.4 & 26.6 & 68.0 \\
\hline & & $\%$ within Professionalism & $61.8 \%$ & $38.2 \%$ & $100.0 \%$ \\
\hline & & $\%$ within PEGradReq & $79.2 \%$ & $76.5 \%$ & $78.2 \%$ \\
\hline & & $\%$ of Total & $48.3 \%$ & $29.9 \%$ & $78.2 \%$ \\
\hline Total & & Count & 53 & 34 & 87 \\
\hline & & Expected Count & 53.0 & 34.0 & 87.0 \\
\hline & & $\%$ within Professionalism & $60.9 \%$ & $39.1 \%$ & $100.0 \%$ \\
\hline & & $\%$ within PEGradReq & $100.0 \%$ & $100.0 \%$ & $100.0 \%$ \\
\hline & & $\%$ of Total & $60.9 \%$ & $39.1 \%$ & $100.0 \%$ \\
\hline
\end{tabular}

\section{Chi-Square Tests}

\begin{tabular}{|l|r|r|r|}
\hline & \multicolumn{1}{|c|}{ Value } & df & $\begin{array}{c}\text { Asymp. Sig. (2- } \\
\text { sided) }\end{array}$ \\
\hline Pearson Chi-Square & $.209^{\mathrm{a}}$ & 2 & .901 \\
Likelihood Ratio & .208 & 2 & .901 \\
Linear-by-Linear Association & .030 & 1 & .863 \\
N of Valid Cases & 87 & & \\
\hline
\end{tabular}

a. 2 cells $(33.3 \%)$ have expected count less than 5 . The minimum expected count is 1.17 .

Directional Measures

\begin{tabular}{|c|c|c|c|c|c|}
\hline & & Value & $\begin{array}{c}\text { Asymp. Std. } \\
\text { Error }^{\mathrm{a}}\end{array}$ & Approx. T & $\begin{array}{c}\text { Approx. } \\
\text { Sig. }\end{array}$ \\
\hline \multirow[t]{4}{*}{ Nominal by Nominal Lambda } & Symmetric & .000 & .000 &. & b \\
\hline & Professionalism & .000 & .000 & $b^{b}$ & $b$ \\
\hline & Dependent & & & & \\
\hline & PEGradReq Dependent & .000 & .000 & b &. \\
\hline
\end{tabular}


ADHERENCE TO INSTRUCTIONAL PRACTICE GUIDELINES 164

\begin{tabular}{|ll|r|r|r|}
\hline \begin{tabular}{ll|l|} 
Goodman and Kruskal \\
tau
\end{tabular} & $\begin{array}{l}\text { Professionalism } \\
\text { Dependent } \\
\text { PEGradReq Dependent }\end{array}$ & .001 & .007 & $.884^{\mathrm{c}}$ \\
& .002 & .011 & $.902^{\mathrm{c}}$ \\
\hline
\end{tabular}

a. Not assuming the null hypothesis.

b. Cannot be computed because the asymptotic standard error equals zero.

c. Based on chi-square approximation

\section{Symmetric Measures}

\begin{tabular}{|ll|r|r|}
\hline & & Value & Approx. Sig. \\
\hline Nominal by Nominal & Phi & .049 & .901 \\
& Cramer's V & .049 & .901 \\
& Contingency Coefficient & .049 & .901 \\
N of Valid Cases & & 87 & \\
\hline
\end{tabular}

\section{Professionalism * AAHPERDDist}

\begin{tabular}{|c|c|c|c|c|c|c|c|c|c|}
\hline \multicolumn{10}{|c|}{ Crosstab } \\
\hline & & & \multicolumn{6}{|c|}{ AAHPERDDist } & \multirow[b]{2}{*}{ Total } \\
\hline & & & $\begin{array}{c}\text { EASTE } \\
\text { RN } \\
\end{array}$ & $\begin{array}{c}\text { CENTR } \\
\text { AL } \\
\end{array}$ & $\begin{array}{c}\text { MIDWE } \\
\text { ST }\end{array}$ & $\begin{array}{c}\text { SOUTHE } \\
\text { RN }\end{array}$ & $\begin{array}{c}\text { SOUTHW } \\
\text { EST }\end{array}$ & $\begin{array}{c}\text { NORTHW } \\
\text { EST }\end{array}$ & \\
\hline \multirow{11}{*}{$\begin{array}{l}\text { Professional } \\
\text { ism }\end{array}$} & Not at & Count & 0 & 1 & 1 & 0 & 0 & 1 & 3 \\
\hline & All & Expected Count & .1 & .5 & .7 & 1.3 & .2 & .2 & 3.0 \\
\hline & & $\%$ within & $.0 \%$ & $33.3 \%$ & $33.3 \%$ & $.0 \%$ & $.0 \%$ & $33.3 \%$ & 100.0 \\
\hline & & Professionalism & & & & & & & $\%$ \\
\hline & & $\%$ within & $.0 \%$ & $7.1 \%$ & $5.0 \%$ & $.0 \%$ & $.0 \%$ & $14.3 \%$ & $3.4 \%$ \\
\hline & & AAHPERDDist & & & & & & & \\
\hline & & $\%$ of Total & $.0 \%$ & $1.1 \%$ & $1.1 \%$ & $.0 \%$ & $.0 \%$ & $1.1 \%$ & $3.4 \%$ \\
\hline & Partial & Count & 0 & 4 & 2 & 9 & 1 & 2 & 18 \\
\hline & & Expected Count & .8 & 2.8 & 4.0 & 7.9 & 1.0 & 1.4 & 18.0 \\
\hline & & $\%$ within & $.0 \%$ & $22.2 \%$ & $11.1 \%$ & $50.0 \%$ & $5.6 \%$ & $11.1 \%$ & 100.0 \\
\hline & & Professionalism & & & & & & & $\%$ \\
\hline
\end{tabular}


ADHERENCE TO INSTRUCTIONAL PRACTICE GUIDELINES 165

\begin{tabular}{|c|c|c|c|c|c|c|c|c|c|}
\hline & & $\begin{array}{l}\% \text { within } \\
\text { AAHPERDDist } \\
\% \text { of Total }\end{array}$ & $.0 \%$ & $\begin{array}{r}28.6 \% \\
\\
4.5 \% \\
\end{array}$ & $10.0 \%$ & $\begin{array}{l}23.1 \% \\
10.1 \% \\
\end{array}$ & $20.0 \%$ & $28.6 \%$ & $\begin{array}{l}20.2 \% \\
20.2 \% \\
\end{array}$ \\
\hline & Fully & Count & 4 & 9 & 17 & 30 & 4 & 4 & 68 \\
\hline & & Expected Count & 3.1 & 10.7 & 15.3 & 29.8 & 3.8 & 5.3 & 68.0 \\
\hline & & $\%$ within & $5.9 \%$ & $13.2 \%$ & $25.0 \%$ & $44.1 \%$ & $5.9 \%$ & $5.9 \%$ & 100.0 \\
\hline & & Professionalism & & & & & & & \\
\hline & & \% within & $100.0 \%$ & $64.3 \%$ & $85.0 \%$ & $76.9 \%$ & $80.0 \%$ & $57.1 \%$ & $76.4 \%$ \\
\hline & & AAHPERDDist & & & & & & & \\
\hline & & $\%$ of Total & $4.5 \%$ & $10.1 \%$ & $19.1 \%$ & $33.7 \%$ & $4.5 \%$ & $4.5 \%$ & $76.4 \%$ \\
\hline Total & & Count & 4 & 14 & 20 & 39 & 5 & 7 & 89 \\
\hline & & Expected Count & 4.0 & 14.0 & 20.0 & 39.0 & 5.0 & 7.0 & 89.0 \\
\hline & & \% within & $4.5 \%$ & $15.7 \%$ & $22.5 \%$ & $43.8 \%$ & $5.6 \%$ & $7.9 \%$ & 100.0 \\
\hline & & Professionalism & & & & & & & $\%$ \\
\hline & & \% within & $100.0 \%$ & $100.0 \%$ & $100.0 \%$ & $100.0 \%$ & $100.0 \%$ & $100.0 \%$ & 100.0 \\
\hline & & AAHPERDDist & & & & & & & $\%$ \\
\hline & & $\%$ of Total & $4.5 \%$ & $15.7 \%$ & $22.5 \%$ & $43.8 \%$ & $5.6 \%$ & $7.9 \%$ & 100.0 \\
\hline
\end{tabular}

Chi-Square Tests

\begin{tabular}{|l|r|r|r|}
\hline & \multicolumn{1}{|c|}{ Value } & df & $\begin{array}{c}\text { Asymp. Sig. (2- } \\
\text { sided) }\end{array}$ \\
\hline Pearson Chi-Square & $8.667^{\mathrm{a}}$ & 10 & .564 \\
Likelihood Ratio & 9.979 & 10 & .442 \\
Linear-by-Linear Association & .488 & 1 & .485 \\
N of Valid Cases & 89 & & \\
\hline
\end{tabular}

a. 13 cells $(72.2 \%)$ have expected count less than 5 . The minimum expected count is .13 .

Directional Measures

\begin{tabular}{|c|c|c|c|c|c|}
\hline & & Value & $\begin{array}{c}\text { Asymp. Std. } \\
\text { Error }^{\mathrm{a}}\end{array}$ & Approx. $\mathrm{T}^{\mathrm{b}}$ & $\begin{array}{l}\text { Approx. } \\
\text { Sig. }\end{array}$ \\
\hline Nominal by Nominal Lambda & Symmetric & .014 & .014 & 1.006 & .315 \\
\hline
\end{tabular}


ADHERENCE TO INSTRUCTIONAL PRACTICE GUIDELINES 166

\begin{tabular}{|c|c|c|c|c|c|}
\hline & $\begin{array}{l}\text { Professionalism } \\
\text { Dependent } \\
\text { AAHPERDDist } \\
\text { Dependent } \\
\end{array}$ & $\begin{array}{l}.000 \\
.020\end{array}$ & $\begin{array}{l}.000 \\
.020\end{array}$ & $\begin{array}{r}. c \\
1.006\end{array}$ & .315 \\
\hline $\begin{array}{l}\text { Goodman and Kruskal } \\
\text { tau }\end{array}$ & $\begin{array}{l}\text { Professionalism } \\
\text { Dependent } \\
\text { AAHPERDDist } \\
\text { Dependent }\end{array}$ & $\begin{array}{l}.047 \\
.023\end{array}$ & $\begin{array}{l}.033 \\
.009\end{array}$ & & $\begin{array}{l}.606^{d} \\
.432^{d}\end{array}$ \\
\hline
\end{tabular}

a. Not assuming the null hypothesis.

b. Using the asymptotic standard error assuming the null hypothesis.

c. Cannot be computed because the asymptotic standard error equals zero.

d. Based on chi-square approximation

\section{Symmetric Measures}

\begin{tabular}{|ll|r|r|}
\hline & & Value & Approx. Sig. \\
\hline Nominal by Nominal & Phi & .312 & .564 \\
& Cramer's V & .221 & .564 \\
& Contingency Coefficient & .298 & .564 \\
N of Valid Cases & & 89 & \\
\hline
\end{tabular}

\section{Professionalism * Affiliation}

Crosstab

\begin{tabular}{|c|c|c|c|c|c|}
\hline & & & \multicolumn{2}{|c|}{ Affiliation } & \multirow[b]{2}{*}{ Total } \\
\hline & & & PUBLIC & PRIVATE & \\
\hline \multirow[t]{8}{*}{ Professionalism } & Not at All & Count & 1 & 2 & 3 \\
\hline & & Expected Count & 1.7 & 1.3 & 3.0 \\
\hline & & $\%$ within Professionalism & $33.3 \%$ & $66.7 \%$ & $100.0 \%$ \\
\hline & & $\%$ within Affiliation & $2.0 \%$ & $5.0 \%$ & $3.4 \%$ \\
\hline & & $\%$ of Total & $1.1 \%$ & $2.2 \%$ & $3.4 \%$ \\
\hline & Partial & Count & 13 & 5 & 18 \\
\hline & & Expected Count & 9.9 & 8.1 & 18.0 \\
\hline & & $\%$ within Professionalism & $72.2 \%$ & $27.8 \%$ & $100.0 \%$ \\
\hline
\end{tabular}


ADHERENCE TO INSTRUCTIONAL PRACTICE GUIDELINES 167

\begin{tabular}{|c|c|c|c|c|c|}
\hline & & $\begin{array}{l}\% \text { within Affiliation } \\
\% \text { of Total }\end{array}$ & $\begin{array}{l}26.5 \% \\
14.6 \% \\
\end{array}$ & $\begin{array}{r}12.5 \% \\
5.6 \% \\
\end{array}$ & $\begin{array}{l}20.2 \% \\
20.2 \% \\
\end{array}$ \\
\hline & Fully & Count & 35 & 33 & 68 \\
\hline & & Expected Count & 37.4 & 30.6 & 68.0 \\
\hline & & $\%$ within Professionalism & $51.5 \%$ & $48.5 \%$ & $100.0 \%$ \\
\hline & & $\%$ within Affiliation & $71.4 \%$ & $82.5 \%$ & $76.4 \%$ \\
\hline & & $\%$ of Total & $39.3 \%$ & $37.1 \%$ & $76.4 \%$ \\
\hline Total & & Count & 49 & 40 & 89 \\
\hline & & Expected Count & 49.0 & 40.0 & 89.0 \\
\hline & & $\%$ within Professionalism & $55.1 \%$ & $44.9 \%$ & $100.0 \%$ \\
\hline & & $\%$ within Affiliation & $100.0 \%$ & $100.0 \%$ & $100.0 \%$ \\
\hline & & $\%$ of Total & $55.1 \%$ & $44.9 \%$ & $100.0 \%$ \\
\hline
\end{tabular}

\section{Chi-Square Tests}

\begin{tabular}{|l|r|r|r|}
\hline & \multicolumn{1}{|c|}{ Value } & df & \multicolumn{1}{c|}{$\begin{array}{c}\text { Asymp. Sig. (2- } \\
\text { sided) }\end{array}$} \\
\hline Pearson Chi-Square & $3.069^{\mathrm{a}}$ & 2 & .216 \\
Likelihood Ratio & 3.170 & 2 & .205 \\
Linear-by-Linear Association & .542 & 1 & .462 \\
N of Valid Cases & 89 & & \\
\hline
\end{tabular}

a. 2 cells (33.3\%) have expected count less than 5 . The minimum expected count is 1.35 .

Directional Measures

\begin{tabular}{|c|c|c|c|c|c|c|}
\hline & & & Value & $\begin{array}{l}\text { Asymp. Std. } \\
\text { Error }^{\mathrm{a}}\end{array}$ & Approx. $\mathrm{T}^{\mathrm{b}}$ & $\begin{array}{l}\text { Approx. } \\
\text { Sig. }\end{array}$ \\
\hline \multirow[t]{5}{*}{ Nominal by Nominal } & Lambda & Symmetric & .016 & .028 & .578 & .563 \\
\hline & & Professionalism & .000 & .000 &.$^{c}$ & $0^{\circ}$ \\
\hline & & Dependent & & & & \\
\hline & & Affiliation Dependent & .025 & .043 & .578 & .563 \\
\hline & $\begin{array}{l}\text { Goodman and Kruskal } \\
\text { tau }\end{array}$ & $\begin{array}{l}\text { Professionalism } \\
\text { Dependent }\end{array}$ & .022 & .027 & & $.148^{\circ}$ \\
\hline
\end{tabular}




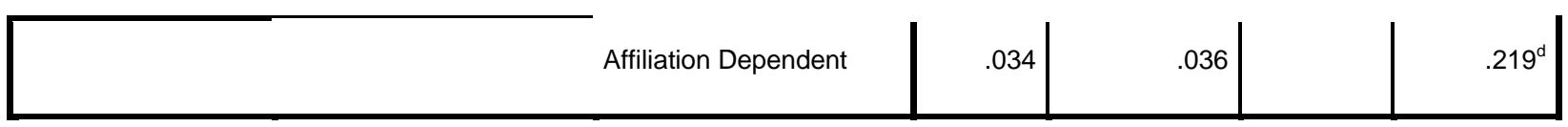

a. Not assuming the null hypothesis.

b. Using the asymptotic standard error assuming the null hypothesis.

c. Cannot be computed because the asymptotic standard error equals zero.

d. Based on chi-square approximation

\section{Symmetric Measures}

\begin{tabular}{|ll|r|r|}
\hline & & \multicolumn{1}{|c|}{ Value } & Approx. Sig. \\
\hline Nominal by Nominal & Phi & .186 & .216 \\
& Cramer's V & .186 & .216 \\
& Contingency Coefficient & .183 & .216 \\
N of Valid Cases & & 89 & \\
\hline
\end{tabular}

\section{Professionalism * EnrollmentCondense}

\begin{tabular}{|c|c|c|c|c|c|c|}
\hline \multicolumn{7}{|c|}{ Crosstab } \\
\hline & & & \multicolumn{3}{|c|}{ EnrollmentCondense } & \multirow[b]{2}{*}{ Total } \\
\hline & & & $\begin{array}{c}\text { Small (500- } \\
2500) \\
\end{array}$ & $\begin{array}{c}\text { Medium } \\
(2501-10000) \\
\end{array}$ & $\begin{array}{c}\text { Large } \\
(>10,000)\end{array}$ & \\
\hline \multirow[t]{11}{*}{ Professionalism } & Not at All & Count & 2 & 0 & 1 & 3 \\
\hline & & Expected Count & 1.2 & .9 & .8 & 3.0 \\
\hline & & $\%$ within Professionalism & $66.7 \%$ & $.0 \%$ & $33.3 \%$ & $100.0 \%$ \\
\hline & & $\%$ within & $5.4 \%$ & $.0 \%$ & $4.0 \%$ & $3.4 \%$ \\
\hline & & EnrollmentCondense & & & & \\
\hline & & $\%$ of Total & $2.2 \%$ & $.0 \%$ & $1.1 \%$ & $3.4 \%$ \\
\hline & Partial & Count & 6 & 4 & 8 & 18 \\
\hline & & Expected Count & 7.5 & 5.5 & 5.1 & 18.0 \\
\hline & & $\%$ within Professionalism & $33.3 \%$ & $22.2 \%$ & $44.4 \%$ & $100.0 \%$ \\
\hline & & $\%$ within & $16.2 \%$ & $14.8 \%$ & $32.0 \%$ & $20.2 \%$ \\
\hline & & EnrollmentCondense & & & & \\
\hline
\end{tabular}


ADHERENCE TO INSTRUCTIONAL PRACTICE GUIDELINES 169

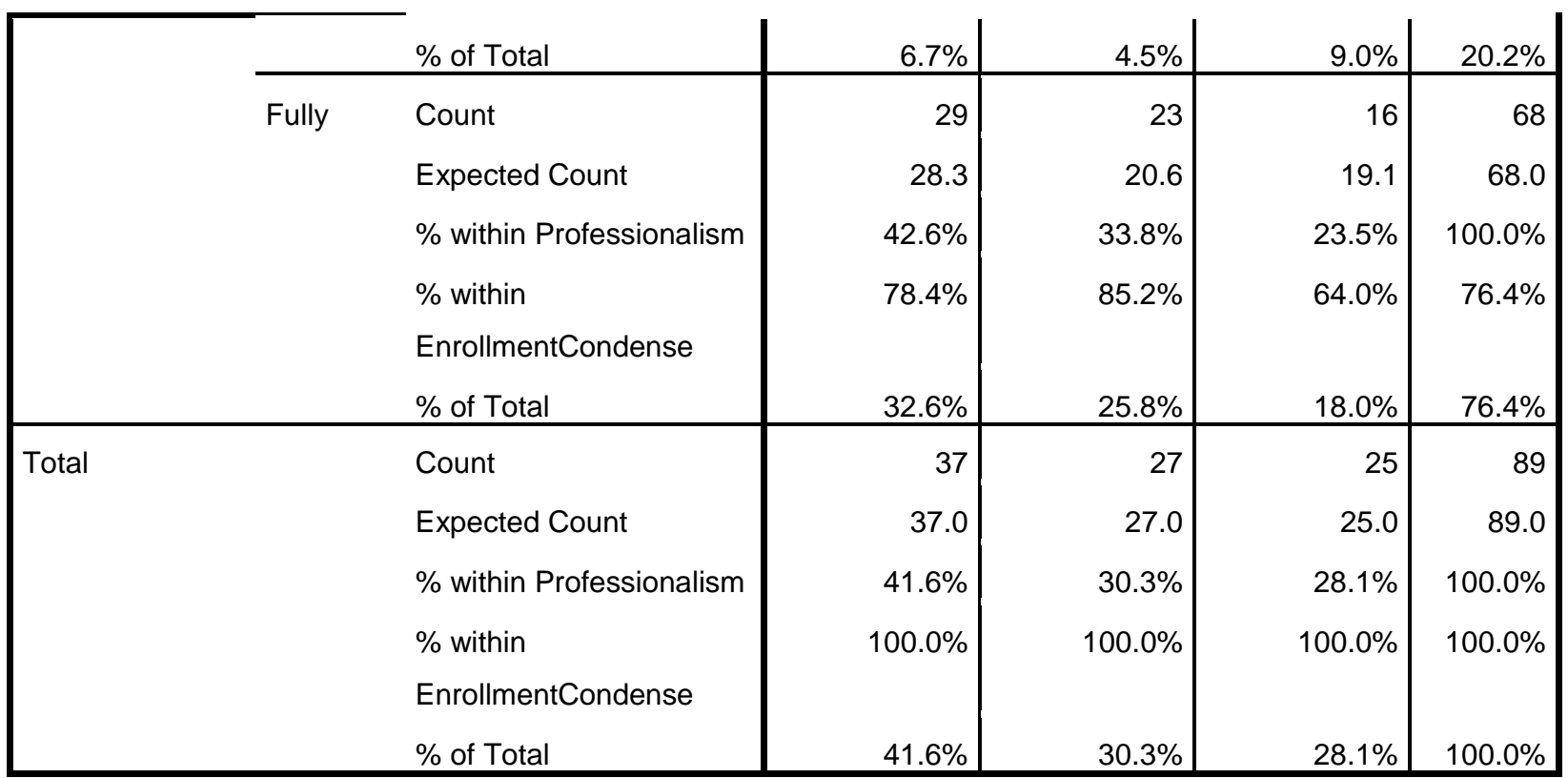

\section{Chi-Square Tests}

\begin{tabular}{|c|c|c|c|}
\hline & Value & df & $\begin{array}{c}\text { Asymp. Sig. (2- } \\
\text { sided) }\end{array}$ \\
\hline Pearson Chi-Square & $4.587^{\mathrm{a}}$ & 4 & .332 \\
\hline Likelihood Ratio & 5.246 & 4 & .263 \\
\hline Linear-by-Linear Association & .649 & 1 & .421 \\
\hline $\mathrm{N}$ of Valid Cases & 89 & & \\
\hline
\end{tabular}

a. 3 cells $(33.3 \%)$ have expected count less than 5 . The minimum expected count is 84 .

Directional Measures

\begin{tabular}{|ll|r|r|r|r|}
\hline & & Value & $\begin{array}{c}\text { Asymp. Std. } \\
\text { Error }^{\mathrm{a}}\end{array}$ & $\begin{array}{c}\text { Approx. } \\
\text { Approx. } \mathrm{T}^{\mathrm{b}}\end{array}$ \\
\hline Sominal by Nominal Lambda & Symmetric & .027 & .050 & .535 & .592 \\
& Professionalism & .000 & .000 &. \\
& Dependent & & .071 \\
& EnrollmentCondense & .038 & .535 & .592 \\
\hline
\end{tabular}


ADHERENCE TO INSTRUCTIONAL PRACTICE GUIDELINES 170

\begin{tabular}{|ll|r|r|r|}
\hline $\begin{array}{ll}\text { Goodman and Kruskal } \\
\text { tau }\end{array}$ & $\begin{array}{l}\text { Professionalism } \\
\text { Dependent } \\
\end{array}$ & $\begin{array}{l}\text { EnrollmentCondense } \\
\text { Dependent }\end{array}$ & .024 & .037 \\
& $.367^{\mathrm{d}}$ \\
\hline
\end{tabular}

a. Not assuming the null hypothesis.

b. Using the asymptotic standard error assuming the null hypothesis.

c. Cannot be computed because the asymptotic standard error equals zero.

d. Based on chi-square approximation

\section{Symmetric Measures}

\begin{tabular}{|ll|r|r|}
\hline & & \multicolumn{1}{|c|}{ Value } & Approx. Sig. \\
\hline Nominal by Nominal & Phi & .227 & .332 \\
& Cramer's V & .161 & .332 \\
& Contingency Coefficient & .221 & .332 \\
N of Valid Cases & & 89 & \\
\hline
\end{tabular}

\section{LearningEnvironment * PEGradReq}

\section{Crosstab}

\begin{tabular}{|c|c|c|c|c|c|}
\hline & & & \multicolumn{2}{|c|}{ PEGradReq } & \multirow[b]{2}{*}{ Total } \\
\hline & & & YES & $\mathrm{NO}$ & \\
\hline \multirow[t]{13}{*}{ LearningEnvironment } & \multirow[t]{6}{*}{ Not at All } & Count & 1 & 0 & 1 \\
\hline & & Expected Count & 6 & .4 & 1.0 \\
\hline & & $\%$ within & $100.0 \%$ & $.0 \%$ & $100.0 \%$ \\
\hline & & LearningEnvironment & & & \\
\hline & & \% within PEGradReq & $1.9 \%$ & $.0 \%$ & $1.1 \%$ \\
\hline & & $\%$ of Total & $1.1 \%$ & $.0 \%$ & $1.1 \%$ \\
\hline & \multirow[t]{6}{*}{ Partial } & Count & 12 & 14 & 26 \\
\hline & & Expected Count & 15.8 & 10.2 & 26.0 \\
\hline & & $\%$ within & $46.2 \%$ & $53.8 \%$ & $100.0 \%$ \\
\hline & & LearningEnvironment & & & \\
\hline & & \% within PEGradReq & $22.6 \%$ & $41.2 \%$ & $29.9 \%$ \\
\hline & & $\%$ of Total & $13.8 \%$ & $16.1 \%$ & $29.9 \%$ \\
\hline & Fully & Count & 40 & 20 & 60 \\
\hline
\end{tabular}


ADHERENCE TO INSTRUCTIONAL PRACTICE GUIDELINES 171

\begin{tabular}{|c|c|c|c|c|}
\hline & Expected Count & 36.6 & 23.4 & 60.0 \\
\hline & $\%$ within & $66.7 \%$ & $33.3 \%$ & $100.0 \%$ \\
\hline & LearningEnvironment & & & \\
\hline & $\%$ within PEGradReq & $75.5 \%$ & $58.8 \%$ & $69.0 \%$ \\
\hline & $\%$ of Total & $46.0 \%$ & $23.0 \%$ & $69.0 \%$ \\
\hline \multirow[t]{6}{*}{ Total } & Count & 53 & 34 & 87 \\
\hline & Expected Count & 53.0 & 34.0 & 87.0 \\
\hline & $\%$ within & $60.9 \%$ & $39.1 \%$ & $100.0 \%$ \\
\hline & LearningEnvironment & & & \\
\hline & $\%$ within PEGradReq & $100.0 \%$ & $100.0 \%$ & $100.0 \%$ \\
\hline & $\%$ of Total & $60.9 \%$ & $39.1 \%$ & $100.0 \%$ \\
\hline
\end{tabular}

Chi-Square Tests

\begin{tabular}{|c|c|c|c|}
\hline & Value & $\mathrm{df}$ & $\begin{array}{c}\text { Asymp. Sig. (2- } \\
\text { sided) }\end{array}$ \\
\hline Pearson Chi-Square & $3.855^{\mathrm{a}}$ & 2 & .146 \\
\hline Likelihood Ratio & 4.153 & 2 & .125 \\
\hline Linear-by-Linear Association & 1.849 & 1 & .174 \\
\hline $\mathrm{N}$ of Valid Cases & 87 & & \\
\hline
\end{tabular}

a. 2 cells (33.3\%) have expected count less than 5 . The minimum expected count is 39 .

Directional Measures

\begin{tabular}{|c|c|c|c|c|c|c|}
\hline & & & Value & $\begin{array}{c}\text { Asymp. Std. } \\
\text { Error }^{\mathrm{a}}\end{array}$ & Approx. $\mathrm{T}^{\mathrm{b}}$ & $\begin{array}{c}\text { Approx. } \\
\text { Sig. }\end{array}$ \\
\hline \multirow[t]{7}{*}{ Nominal by Nominal } & \multirow[t]{4}{*}{ Lambda } & Symmetric & .033 & .082 & .393 & .695 \\
\hline & & LearningEnvironment & .000 & .000 & $\therefore$ & $\therefore$ \\
\hline & & Dependent & & & & \\
\hline & & PEGradReq Dependent & .059 & .145 & .393 & .695 \\
\hline & \multirow{3}{*}{$\begin{array}{l}\text { Goodman and Kruskal } \\
\text { tau }\end{array}$} & LearningEnvironment & .034 & .039 & & $.053^{d}$ \\
\hline & & Dependent & & & & \\
\hline & & PEGradReq Dependent & .044 & .041 & & $.149^{d}$ \\
\hline
\end{tabular}


Directional Measures

\begin{tabular}{|c|c|c|c|c|c|c|}
\hline & & & Value & $\begin{array}{c}\text { Asymp. Std. } \\
\text { Error }^{\mathrm{a}}\end{array}$ & Approx. $T^{\mathrm{b}}$ & $\begin{array}{l}\text { Approx. } \\
\text { Sig. }\end{array}$ \\
\hline \multirow[t]{6}{*}{ Nominal by Nominal } & Lambda & Symmetric & .033 & .082 & .393 & .695 \\
\hline & & LearningEnvironment & .000 & .000 &.$^{c}$ & c \\
\hline & & Dependent & & & & \\
\hline & & PEGradReq Dependent & .059 & .145 & .393 & .695 \\
\hline & \multirow[t]{2}{*}{$\begin{array}{l}\text { Goodman and Kruskal } \\
\text { tau }\end{array}$} & $\begin{array}{l}\text { LearningEnvironment } \\
\text { Dependent }\end{array}$ & .034 & .039 & & $.053^{\mathrm{d}}$ \\
\hline & & PEGradReq Dependent & .044 & .041 & & $.149^{\mathrm{d}}$ \\
\hline
\end{tabular}

a. Not assuming the null hypothesis.

b. Using the asymptotic standard error assuming the null hypothesis.

c. Cannot be computed because the asymptotic standard error equals zero.

d. Based on chi-square approximation

Symmetric Measures

\begin{tabular}{|ll|r|r|}
\hline & & Value & Approx. Sig. \\
\hline Nominal by Nominal & Phi & .210 & .146 \\
& Cramer's V & .210 & .146 \\
& Contingency Coefficient & .206 & .146 \\
N of Valid Cases & & 87 & \\
& & & \\
\hline
\end{tabular}

\section{LearningEnvironment * AAHPERDDist}

\begin{tabular}{|c|c|c|c|c|c|c|c|c|c|}
\hline \multicolumn{10}{|c|}{ Crosstab } \\
\hline & & & \multicolumn{6}{|c|}{ AAHPERDDist } & \multirow[b]{2}{*}{ Total } \\
\hline & & & $\begin{array}{c}\text { EASTE } \\
\text { RN } \\
\end{array}$ & $\begin{array}{l}\text { CENT } \\
\text { RAL }\end{array}$ & $\begin{array}{c}\text { MIDW } \\
\text { EST }\end{array}$ & $\begin{array}{c}\text { SOUTH } \\
\text { ERN } \\
\end{array}$ & $\begin{array}{c}\text { SOUTHW } \\
\text { EST }\end{array}$ & $\begin{array}{c}\text { NORTHW } \\
\text { EST }\end{array}$ & \\
\hline \multirow{4}{*}{$\begin{array}{l}\text { LearningEnviro } \\
\text { nment }\end{array}$} & Not at & Count & 0 & 0 & 0 & 0 & 0 & 1 & 1 \\
\hline & All & Expected Count & .0 & .2 & .2 & .4 & .1 & .1 & 1.0 \\
\hline & & $\%$ within & $.0 \%$ & $.0 \%$ & $.0 \%$ & $.0 \%$ & $.0 \%$ & $100.0 \%$ & 100.0 \\
\hline & & LearningEnvironm & & & & & & & $\%$ \\
\hline
\end{tabular}


ADHERENCE TO INSTRUCTIONAL PRACTICE GUIDELINES 173

\begin{tabular}{|c|c|c|c|c|c|c|c|c|c|}
\hline & & $\begin{array}{l}\text { \% within } \\
\text { AAHPERDDist } \\
\% \text { of Total }\end{array}$ & $.0 \%$ & $.0 \%$ & $.0 \%$ & $.0 \%$ & $.0 \%$ & $14.3 \%$ & $\begin{array}{r}1.1 \% \\
1.1 \% \\
\end{array}$ \\
\hline & Partial & Count & 1 & 4 & 6 & 12 & 1 & 3 & 27 \\
\hline & & Expected Count & 1.2 & 4.2 & 6.1 & 11.8 & 1.5 & 2.1 & 27.0 \\
\hline & & $\%$ within & $3.7 \%$ & $14.8 \%$ & $22.2 \%$ & $44.4 \%$ & $3.7 \%$ & $11.1 \%$ & 100.0 \\
\hline & & LearningEnvironm & & & & & & & \\
\hline & & ent & & & & & & & \\
\hline & & $\%$ within & $25.0 \%$ & $28.6 \%$ & $30.0 \%$ & $30.8 \%$ & $20.0 \%$ & $42.9 \%$ & $30.3 \%$ \\
\hline & & AAHPERDDist & & & & & & & \\
\hline & & $\%$ of Total & $1.1 \%$ & $4.5 \%$ & $6.7 \%$ & $13.5 \%$ & $1.1 \%$ & $3.4 \%$ & $30.3 \%$ \\
\hline & Fully & Count & 3 & 10 & 14 & 27 & 4 & 3 & 61 \\
\hline & & Expected Count & 2.7 & 9.6 & 13.7 & 26.7 & 3.4 & 4.8 & 61.0 \\
\hline & & $\%$ within & $4.9 \%$ & $16.4 \%$ & $23.0 \%$ & $44.3 \%$ & $6.6 \%$ & $4.9 \%$ & 100.0 \\
\hline & & LearningEnvironm & & & & & & & $\%$ \\
\hline & & ent & & & & & & & \\
\hline & & $\%$ within & $75.0 \%$ & $71.4 \%$ & $70.0 \%$ & $69.2 \%$ & $80.0 \%$ & $42.9 \%$ & $68.5 \%$ \\
\hline & & AAHPERDDist & & & & & & & \\
\hline & & $\%$ of Total & $3.4 \%$ & $11.2 \%$ & $15.7 \%$ & $30.3 \%$ & $4.5 \%$ & $3.4 \%$ & $68.5 \%$ \\
\hline Total & & Count & 4 & 14 & 20 & 39 & 5 & 7 & 89 \\
\hline & & Expected Count & 4.0 & 14.0 & 20.0 & 39.0 & 5.0 & 7.0 & 89.0 \\
\hline & & $\%$ within & $4.5 \%$ & $15.7 \%$ & $22.5 \%$ & $43.8 \%$ & $5.6 \%$ & $7.9 \%$ & 100.0 \\
\hline & & LearningEnvironm & & & & & & & $\%$ \\
\hline & & ent & & & & & & & \\
\hline & & $\%$ within & 100.0 & $100.0 \%$ & 100.0 & $100.0 \%$ & $100.0 \%$ & $100.0 \%$ & 100.0 \\
\hline & & AAHPERDDist & $\%$ & & & & & & $\%$ \\
\hline & & $\%$ of Total & $4.5 \%$ & $15.7 \%$ & $22.5 \%$ & $43.8 \%$ & $5.6 \%$ & $7.9 \%$ & 100.0 \\
\hline
\end{tabular}

Chi-Square Tests

\begin{tabular}{|l|r|r|r|}
\hline & Value & df & \multicolumn{1}{|c|}{$\begin{array}{c}\text { Asymp. Sig. (2- } \\
\text { sided) }\end{array}$} \\
\hline Pearson Chi-Square & $13.127^{\mathrm{a}}$ & 10 & .217 \\
Likelihood Ratio & 6.582 & 10 & .764 \\
Linear-by-Linear Association & 1.754 & 1 & .185 \\
\hline
\end{tabular}


$\mathrm{N}$ of Valid Cases

89

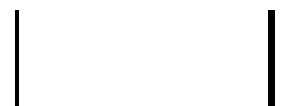

a. 13 cells $(72.2 \%)$ have expected count less than 5 . The minimum

expected count is .04 .

Directional Measures

\begin{tabular}{|c|c|c|c|c|c|c|}
\hline & & & Value & $\begin{array}{c}\text { Asymp. Std. } \\
\text { Error }^{\mathrm{a}}\end{array}$ & Approx. $\mathrm{T}^{\mathrm{b}}$ & $\begin{array}{l}\text { Approx. } \\
\text { Sig. }\end{array}$ \\
\hline \multirow[t]{9}{*}{ Nominal by Nominal } & Lambda & Symmetric & .013 & .034 & .378 & .705 \\
\hline & & LearningEnvironment & .000 & .087 & .000 & 1.000 \\
\hline & & Dependent & & & & \\
\hline & & AAHPERDDist & .020 & .020 & 1.006 & .315 \\
\hline & & Dependent & & & & \\
\hline & Goodman and Kruskal & LearningEnvironment & .022 & .028 & & $.950^{\mathrm{c}}$ \\
\hline & tau & Dependent & & & & \\
\hline & & AAHPERDDist & .019 & .003 & & $.587^{\mathrm{c}}$ \\
\hline & & Dependent & & & & \\
\hline
\end{tabular}

a. Not assuming the null hypothesis.

b. Using the asymptotic standard error assuming the null hypothesis.

c. Based on chi-square approximation

Symmetric Measures

\begin{tabular}{|ll|r|r|}
\hline & & \multicolumn{1}{|c|}{ Value } & Approx. Sig. \\
\hline Nominal by Nominal & Phi & .384 & .217 \\
& Cramer's V & .272 & .217 \\
& Contingency Coefficient & .359 & .217 \\
N of Valid Cases & & 89 & \\
\hline
\end{tabular}

\section{LearningEnvironment * Affiliation}

\section{Crosstab}


ADHERENCE TO INSTRUCTIONAL PRACTICE GUIDELINES 175

\begin{tabular}{|c|c|c|c|c|c|}
\hline & & & Affili & ition & \\
\hline & & & PUBLIC & PRIVATE & Total \\
\hline LearningEnvironment & Not at All & Count & 0 & 1 & 1 \\
\hline & & Expected Count & .6 & .4 & 1.0 \\
\hline & & $\%$ within & $.0 \%$ & $100.0 \%$ & $100.0 \%$ \\
\hline & & LearningEnvironment & & & \\
\hline & & $\%$ within Affiliation & $.0 \%$ & $2.5 \%$ & $1.1 \%$ \\
\hline & & $\%$ of Total & $.0 \%$ & $1.1 \%$ & $1.1 \%$ \\
\hline & Partial & Count & 19 & 8 & 27 \\
\hline & & Expected Count & 14.9 & 12.1 & 27.0 \\
\hline & & $\%$ within & $70.4 \%$ & $29.6 \%$ & $100.0 \%$ \\
\hline & & LearningEnvironment & & & \\
\hline & & $\%$ within Affiliation & $38.8 \%$ & $20.0 \%$ & $30.3 \%$ \\
\hline & & $\%$ of Total & $21.3 \%$ & $9.0 \%$ & $30.3 \%$ \\
\hline & Fully & Count & 30 & 31 & 61 \\
\hline & & Expected Count & 33.6 & 27.4 & 61.0 \\
\hline & & $\%$ within & $49.2 \%$ & $50.8 \%$ & $100.0 \%$ \\
\hline & & LearningEnvironment & & & \\
\hline & & $\%$ within Affiliation & $61.2 \%$ & $77.5 \%$ & $68.5 \%$ \\
\hline & & $\%$ of Total & $33.7 \%$ & $34.8 \%$ & $68.5 \%$ \\
\hline Total & & Count & 49 & 40 & 89 \\
\hline & & Expected Count & 49.0 & 40.0 & 89.0 \\
\hline & & $\%$ within & $55.1 \%$ & $44.9 \%$ & $100.0 \%$ \\
\hline & & LearningEnvironment & & & \\
\hline & & $\%$ within Affiliation & $100.0 \%$ & $100.0 \%$ & $100.0 \%$ \\
\hline & & $\%$ of Total & $55.1 \%$ & $44.9 \%$ & $100.0 \%$ \\
\hline
\end{tabular}

\section{Chi-Square Tests}

\begin{tabular}{|c|c|c|c|}
\hline & Value & $\mathrm{df}$ & $\begin{array}{c}\text { Asymp. Sig. (2- } \\
\text { sided) }\end{array}$ \\
\hline Pearson Chi-Square & $4.635^{\mathrm{a}}$ & 2 & .099 \\
\hline Likelihood Ratio & 5.106 & 2 & .078 \\
\hline Linear-by-Linear Association & 1.706 & 1 & .191 \\
\hline $\mathrm{N}$ of Valid Cases & 89 & & \\
\hline
\end{tabular}


ADHERENCE TO INSTRUCTIONAL PRACTICE GUIDELINES 176

\section{Chi-Square Tests}

\begin{tabular}{|c|c|c|c|}
\hline & Value & $\mathrm{df}$ & $\begin{array}{c}\text { Asymp. Sig. (2- } \\
\text { sided) }\end{array}$ \\
\hline Pearson Chi-Square & $4.635^{\mathrm{a}}$ & 2 & .099 \\
\hline Likelihood Ratio & 5.106 & 2 & .078 \\
\hline Linear-by-Linear Association & 1.706 & 1 & .191 \\
\hline $\mathrm{N}$ of Valid Cases & 89 & & \\
\hline
\end{tabular}

a. 2 cells $(33.3 \%)$ have expected count less than 5 . The minimum expected count is .45 .

Directional Measures

\begin{tabular}{|c|c|c|c|c|c|c|}
\hline & & & Value & $\begin{array}{c}\text { Asymp. Std. } \\
\text { Error }^{\mathrm{a}}\end{array}$ & Approx. $T^{b}$ & $\begin{array}{c}\text { Approx. } \\
\text { Sig. }\end{array}$ \\
\hline \multirow[t]{7}{*}{ Nominal by Nominal } & \multirow[t]{4}{*}{ Lambda } & Symmetric & .029 & .114 & .254 & .799 \\
\hline & & LearningEnvironment & .000 & .000 &.$^{\mathrm{c}}$ & \\
\hline & & Dependent & & & & \\
\hline & & Affiliation Dependent & .050 & .192 & .254 & .799 \\
\hline & \multirow{3}{*}{$\begin{array}{l}\text { Goodman and Kruskal } \\
\text { tau }\end{array}$} & LearningEnvironment & .035 & .037 & & $.045^{d}$ \\
\hline & & Dependent & & & & \\
\hline & & Affiliation Dependent & .052 & .039 & & $.101^{d}$ \\
\hline
\end{tabular}

a. Not assuming the null hypothesis.

b. Using the asymptotic standard error assuming the null hypothesis.

c. Cannot be computed because the asymptotic standard error equals zero.

d. Based on chi-square approximation

Symmetric Measures

\begin{tabular}{|ll|r|r|}
\hline & & & \\
\hline Nominal by Nominal & Phi & \multicolumn{1}{|c|}{ Value } & Approx. Sig. \\
& Cramer's V & .228 & .099 \\
& Contingency Coefficient & .228 & .099 \\
& & .222 & .099
\end{tabular}


Symmetric Measures

\begin{tabular}{|ll|r|r|}
\hline & & \multicolumn{1}{|c|}{ Value } & Approx. Sig. \\
\hline Nominal by Nominal & Phi & .228 & .099 \\
& Cramer's V & .228 & .099 \\
& Contingency Coefficient & .222 & .099 \\
N of Valid Cases & & 89 & \\
\hline
\end{tabular}

\section{LearningEnvironment * EnrollmentCondense}

\begin{tabular}{|c|c|c|c|c|c|c|}
\hline \multicolumn{7}{|c|}{ Crosstab } \\
\hline & & & \multicolumn{3}{|c|}{ EnrollmentCondense } & \multirow[b]{2}{*}{ Total } \\
\hline & & & $\begin{array}{c}\text { Small (500- } \\
2500) \\
\end{array}$ & $\begin{array}{c}\text { Medium } \\
(2501-10000) \\
\end{array}$ & $\begin{array}{c}\text { Large } \\
(>10,000)\end{array}$ & \\
\hline \multirow{21}{*}{$\begin{array}{l}\text { Learning Environme } \\
\text { nt }\end{array}$} & \multirow{7}{*}{ Not at All } & Count & 1 & 0 & 0 & 1 \\
\hline & & Expected Count & .4 & .3 & .3 & 1.0 \\
\hline & & $\%$ within & $100.0 \%$ & $.0 \%$ & $.0 \%$ & $100.0 \%$ \\
\hline & & LearningEnvironment & & & & \\
\hline & & $\%$ within & $2.7 \%$ & $.0 \%$ & $.0 \%$ & $1.1 \%$ \\
\hline & & EnrollmentCondense & & & & \\
\hline & & $\%$ of Total & $1.1 \%$ & $.0 \%$ & $.0 \%$ & $1.1 \%$ \\
\hline & \multirow[t]{7}{*}{ Partial } & Count & 9 & 6 & 12 & 27 \\
\hline & & Expected Count & 11.2 & 8.2 & 7.6 & 27.0 \\
\hline & & $\%$ within & $33.3 \%$ & $22.2 \%$ & $44.4 \%$ & $100.0 \%$ \\
\hline & & LearningEnvironment & & & & \\
\hline & & $\%$ within & $24.3 \%$ & $22.2 \%$ & $48.0 \%$ & $30.3 \%$ \\
\hline & & EnrollmentCondense & & & & \\
\hline & & $\%$ of Total & $10.1 \%$ & $6.7 \%$ & $13.5 \%$ & $30.3 \%$ \\
\hline & \multirow[t]{7}{*}{ Fully } & Count & 27 & 21 & 13 & 61 \\
\hline & & Expected Count & 25.4 & 18.5 & 17.1 & 61.0 \\
\hline & & $\%$ within & $44.3 \%$ & $34.4 \%$ & $21.3 \%$ & $100.0 \%$ \\
\hline & & LearningEnvironment & & & & \\
\hline & & $\%$ within & $73.0 \%$ & $77.8 \%$ & $52.0 \%$ & $68.5 \%$ \\
\hline & & EnrollmentCondense & & & & \\
\hline & & $\%$ of Total & $30.3 \%$ & $23.6 \%$ & $14.6 \%$ & $68.5 \%$ \\
\hline Total & & Count & 37 & 27 & 25 & 89 \\
\hline
\end{tabular}


ADHERENCE TO INSTRUCTIONAL PRACTICE GUIDELINES 178

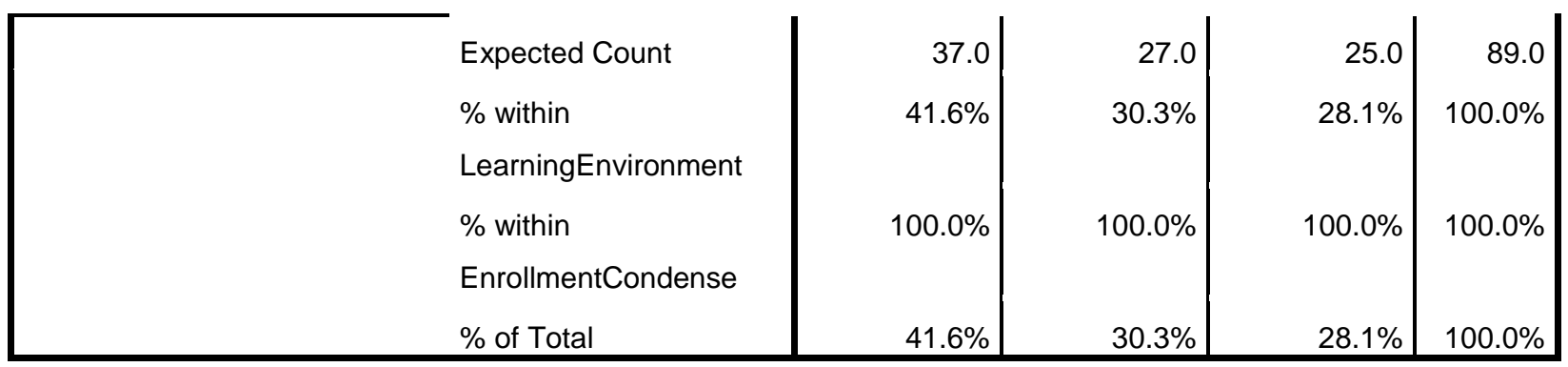

\section{Chi-Square Tests}

\begin{tabular}{|c|c|c|c|}
\hline & Value & df & $\begin{array}{l}\text { Asymp. Sig. (2- } \\
\text { sided) }\end{array}$ \\
\hline Pearson Chi-Square & $6.443^{\mathrm{a}}$ & 4 & 168 \\
\hline Likelihood Ratio & 6.571 & 4 & .160 \\
\hline Linear-by-Linear Association & 1.630 & 1 & .202 \\
\hline $\mathrm{N}$ of Valid Cases & 89 & & \\
\hline
\end{tabular}

a. 3 cells (33.3\%) have expected count less than 5 . The minimum expected count is .28 .

Directional Measures

\begin{tabular}{|c|c|c|c|c|c|c|}
\hline & & & Value & $\begin{array}{c}\text { Asymp. Std. } \\
\text { Error }^{\mathrm{a}}\end{array}$ & Approx. $\mathrm{T}^{\mathrm{b}}$ & $\begin{array}{l}\text { Approx. } \\
\text { Sig. }\end{array}$ \\
\hline \multirow[t]{9}{*}{ Nominal by Nominal } & \multirow[t]{5}{*}{ Lambda } & Symmetric & .038 & .056 & .656 & .512 \\
\hline & & LearningEnvironment & .000 & .000 & & c \\
\hline & & Dependent & & & & \\
\hline & & EnrollmentCondense & .058 & .086 & .656 & .512 \\
\hline & & Dependent & & & & \\
\hline & \multirow{4}{*}{$\begin{array}{l}\text { Goodman and Kruskal } \\
\text { tau }\end{array}$} & LearningEnvironment & \multirow[t]{2}{*}{.054} & \multirow[t]{2}{*}{.049} & & \multirow[t]{2}{*}{$.051^{\circ}$} \\
\hline & & Dependent & & & & \\
\hline & & EnrollmentCondense & \multirow[t]{2}{*}{.035} & \multirow[t]{2}{*}{.024} & & \multirow[t]{2}{*}{$.192^{\circ}$} \\
\hline & & Dependent & & & & \\
\hline
\end{tabular}


Directional Measures

\begin{tabular}{|c|c|c|c|c|c|c|}
\hline & & & Value & $\begin{array}{c}\text { Asymp. Std. } \\
\text { Error }^{\mathrm{a}}\end{array}$ & Approx. $\mathrm{T}^{\mathrm{b}}$ & $\begin{array}{c}\text { Approx. } \\
\text { Sig. }\end{array}$ \\
\hline \multirow[t]{9}{*}{ Nominal by Nominal } & \multirow[t]{5}{*}{ Lambda } & Symmetric & .038 & .056 & .656 & .512 \\
\hline & & LearningEnvironment & .000 & .000 &.$^{c}$ &.$^{c}$ \\
\hline & & Dependent & & & & \\
\hline & & EnrollmentCondense & .058 & .086 & .656 & .512 \\
\hline & & Dependent & & & & \\
\hline & \multirow{4}{*}{$\begin{array}{l}\text { Goodman and Kruskal } \\
\text { tau }\end{array}$} & LearningEnvironment & \multirow[t]{2}{*}{.054} & \multirow[t]{2}{*}{.049} & & \multirow[t]{2}{*}{$.051^{\mathrm{d}}$} \\
\hline & & Dependent & & & & \\
\hline & & EnrollmentCondense & \multirow[t]{2}{*}{.035} & \multirow[t]{2}{*}{.024} & & \multirow[t]{2}{*}{$.192^{\mathrm{d}}$} \\
\hline & & Dependent & & & & \\
\hline
\end{tabular}

a. Not assuming the null hypothesis.

b. Using the asymptotic standard error assuming the null hypothesis.

c. Cannot be computed because the asymptotic standard error equals zero.

d. Based on chi-square approximation

\section{Symmetric Measures}

\begin{tabular}{|ll|r|r|}
\hline & & \multicolumn{1}{|c|}{ Value } & Approx. Sig. \\
\hline Nominal by Nominal & Phi & .269 & .168 \\
& Cramer's V & .190 & .168 \\
& Contingency Coefficient & .260 & .168 \\
N of Valid Cases & & 89 & \\
\hline
\end{tabular}

\section{Curriculum * PEGradReq}

\begin{tabular}{|c|c|c|c|c|c|}
\hline \multicolumn{6}{|c|}{ Crosstab } \\
\hline & & & \multicolumn{2}{|c|}{ PEGradReq } & \multirow[b]{2}{*}{ Total } \\
\hline & & & YES & $\mathrm{NO}$ & \\
\hline \multirow[t]{4}{*}{ Curriculum } & Not at All & Count & 1 & 1 & 2 \\
\hline & & Expected Count & 1.2 & .8 & 2.0 \\
\hline & & $\%$ within Curriculum & $50.0 \%$ & $50.0 \%$ & $100.0 \%$ \\
\hline & & $\%$ within PEGradReq & $1.9 \%$ & $3.0 \%$ & $2.3 \%$ \\
\hline
\end{tabular}


ADHERENCE TO INSTRUCTIONAL PRACTICE GUIDELINES 180

\begin{tabular}{|ll|r|r|r|}
\hline & \% of Total & $1.2 \%$ & $1.2 \%$ & $2.3 \%$ \\
\hline Partial & Count & 12 & 14 & 26 \\
& Expected Count & 16.0 & 10.0 & 26.0 \\
& \% within Curriculum & $46.2 \%$ & $53.8 \%$ & $100.0 \%$ \\
& \% within PEGradReq & $22.6 \%$ & $42.4 \%$ & $30.2 \%$ \\
& \% of Total & $14.0 \%$ & $16.3 \%$ & $30.2 \%$ \\
\hline Fully & Count & 10 & 18 & 58 \\
& Expected Count & 35.7 & 22.3 & 58.0 \\
& \% within Curriculum & $69.0 \%$ & $31.0 \%$ & $100.0 \%$ \\
& \% within PEGradReq & $75.5 \%$ & $54.5 \%$ & $67.4 \%$ \\
& \% of Total & $46.5 \%$ & $20.9 \%$ & $67.4 \%$ \\
\hline Count & 53 & 33 & 86 \\
& Expected Count & 53.0 & 33.0 & 86.0 \\
& \% within Curriculum & $61.6 \%$ & $38.4 \%$ & $100.0 \%$ \\
& \% within PEGradReq & $100.0 \%$ & $100.0 \%$ & $100.0 \%$ \\
\% of Total & $61.6 \%$ & $38.4 \%$ & $100.0 \%$ \\
\hline
\end{tabular}

Chi-Square Tests

\begin{tabular}{|l|r|r|r|}
\hline & \multicolumn{1}{|c|}{ Value } & df & $\begin{array}{c}\text { Asymp. Sig. (2- } \\
\text { sided) }\end{array}$ \\
\hline Pearson Chi-Square & $4.067^{\mathrm{a}}$ & 2 & .131 \\
Likelihood Ratio & 4.017 & 2 & .134 \\
Linear-by-Linear Association & 3.578 & 1 & .059 \\
N of Valid Cases & 86 & & \\
\hline
\end{tabular}

a. 2 cells $(33.3 \%)$ have expected count less than 5 . The minimum expected count is .77 .

Directional Measures

\begin{tabular}{|lc|r|r|r|r|}
\hline & & Asymp. Std. & \\
& & Value & Error $^{\mathrm{a}}$ & Approx. T & Approx. Sig. \\
\hline Nominal by Nominal Lambda & Symmetric & .033 & .082 & .393 & .695 \\
& Curriculum Dependent & .000 & .000 &. &. \\
\hline
\end{tabular}


ADHERENCE TO INSTRUCTIONAL PRACTICE GUIDELINES 181

\begin{tabular}{|lc|r|r|r|r|}
\hline & PEGradReq Dependent & .061 & .150 & .393 \\
\hline Goodman and Kruskal & Curriculum Dependent & .043 & .043 & .695 \\
\hline tau & & & $.025^{\mathrm{d}}$ \\
& PEGradReq Dependent & .047 & .047 & $.134^{\mathrm{d}}$ \\
\hline
\end{tabular}

a. Not assuming the null hypothesis.

b. Using the asymptotic standard error assuming the null hypothesis.

c. Cannot be computed because the asymptotic standard error equals zero.

d. Based on chi-square approximation

Symmetric Measures

\begin{tabular}{|ll|r|r|}
\hline & & \multicolumn{1}{|c|}{ Value } & Approx. Sig. \\
\hline Nominal by Nominal & Phi & .217 & .131 \\
& Cramer's V & .217 & .131 \\
& Contingency Coefficient & .213 & .131 \\
N of Valid Cases & & 86 & \\
\hline
\end{tabular}

\section{Curriculum * AAHPERDDist}

Crosstab

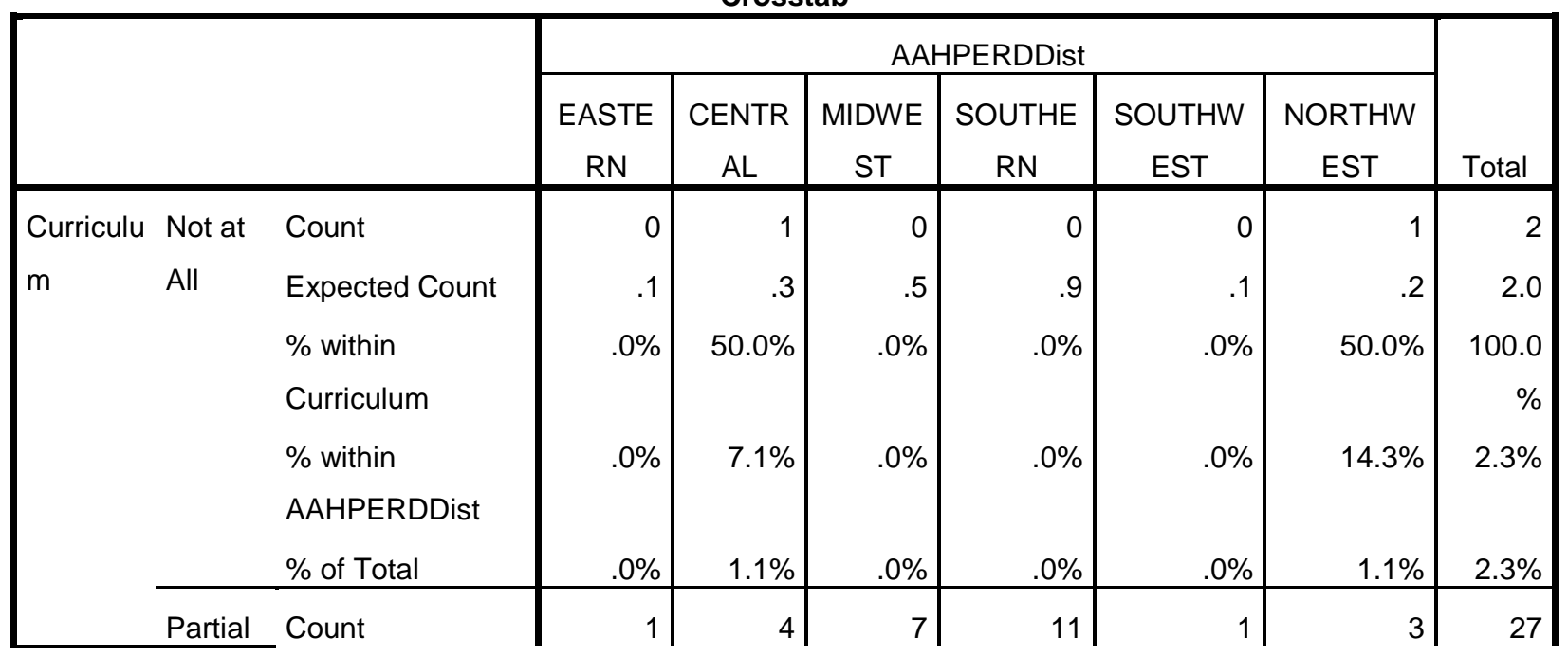


ADHERENCE TO INSTRUCTIONAL PRACTICE GUIDELINES 182

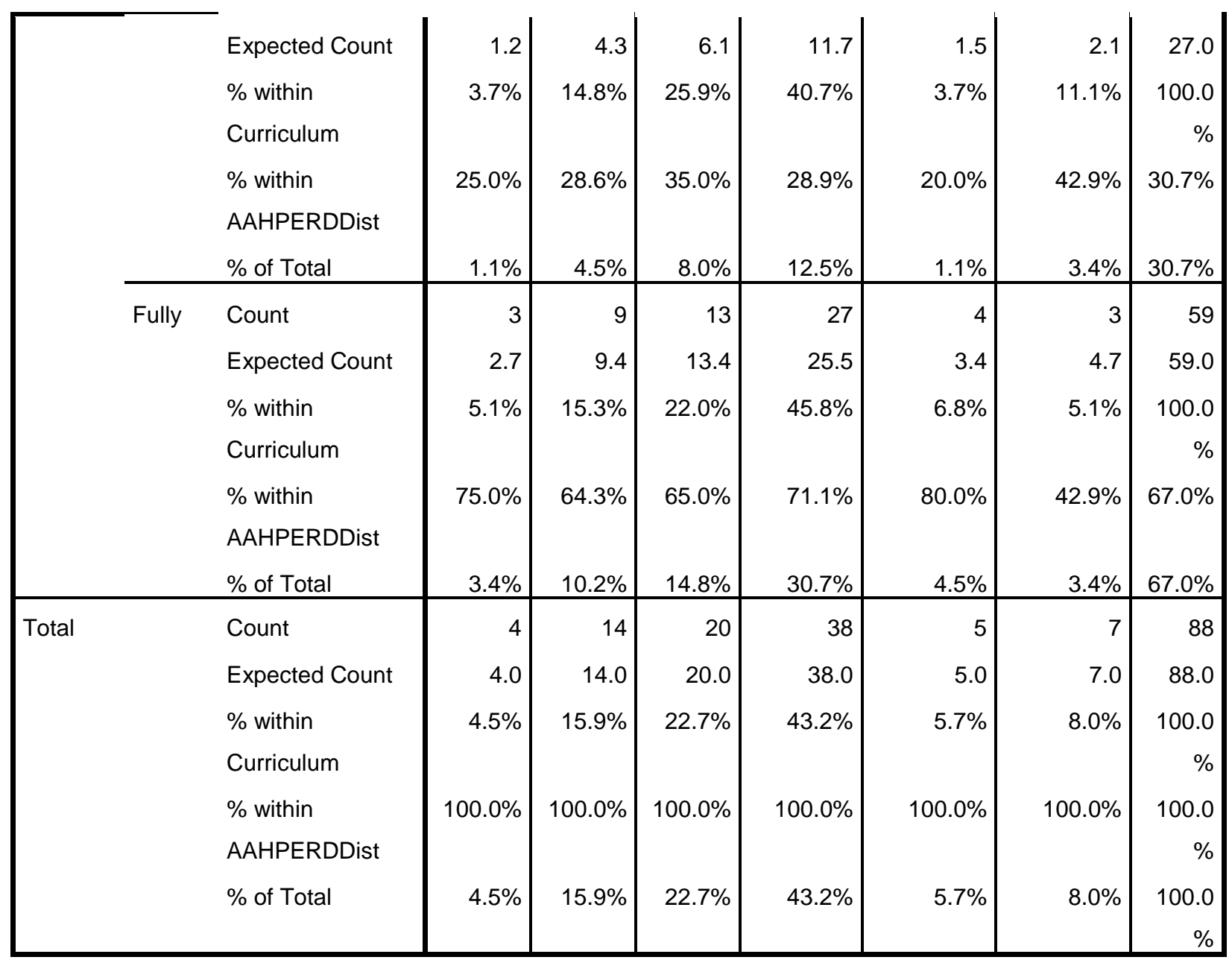

\begin{tabular}{|l|r|r|r|}
\hline & \multicolumn{1}{|c|}{ Chi-Square Tests } \\
& \multicolumn{1}{|c|}{ Value } & df & $\begin{array}{c}\text { Asymp. Sig. (2- } \\
\text { sided) }\end{array}$ \\
\hline Pearson Chi-Square & $9.067^{\mathrm{a}}$ & 10 & .526 \\
Likelihood Ratio & 7.673 & 10 & .661 \\
Linear-by-Linear Association & .340 & 1 & .560 \\
N of Valid Cases & 88 & & \\
\hline
\end{tabular}

a. 13 cells $(72.2 \%)$ have expected count less than 5 . The minimum expected count is .09 . 
Directional Measures

\begin{tabular}{|c|c|c|c|c|c|c|}
\hline & & & Value & $\begin{array}{c}\text { Asymp. Std. } \\
\text { Error }^{\mathrm{a}} \\
\end{array}$ & Approx. $\mathrm{T}^{\mathrm{b}}$ & $\begin{array}{l}\text { Approx. } \\
\text { Sig. }\end{array}$ \\
\hline \multirow[t]{7}{*}{ Nominal by Nominal } & Lambda & Symmetric & .013 & .033 & .378 & .705 \\
\hline & & Curriculum Dependent & .000 & .084 & .000 & 1.000 \\
\hline & & AAHPERDDist & .020 & .020 & 1.006 & .315 \\
\hline & & Dependent & & & & \\
\hline & \multirow{3}{*}{$\begin{array}{l}\text { Goodman and Kruskal } \\
\text { tau }\end{array}$} & Curriculum Dependent & .025 & .029 & & $.932^{\mathrm{c}}$ \\
\hline & & AAHPERDDist & .020 & .006 & & $.570^{\mathrm{c}}$ \\
\hline & & Dependent & & & & \\
\hline
\end{tabular}

a. Not assuming the null hypothesis.

b. Using the asymptotic standard error assuming the null hypothesis.

c. Based on chi-square approximation

Symmetric Measures

\begin{tabular}{|ll|r|r|}
\hline & & \multicolumn{1}{|c|}{ Value } & Approx. Sig. \\
\hline Nominal by Nominal & Phi & .321 & .526 \\
& Cramer's V & .227 & .526 \\
& Contingency Coefficient & .306 & .526 \\
N of Valid Cases & & 88 & \\
& & & \\
\hline
\end{tabular}

\section{Curriculum * Affiliation}

\begin{tabular}{|c|c|c|c|c|c|}
\hline \multicolumn{6}{|c|}{ Crosstab } \\
\hline & & & \multicolumn{2}{|c|}{ Affiliation } & \multirow[b]{2}{*}{ Total } \\
\hline & & & PUBLIC & PRIVATE & \\
\hline \multirow[t]{6}{*}{ Curriculum } & Not at All & Count & 1 & 1 & 2 \\
\hline & & Expected Count & 1.1 & .9 & 2.0 \\
\hline & & $\%$ within Curriculum & $50.0 \%$ & $50.0 \%$ & $100.0 \%$ \\
\hline & & $\%$ within Affiliation & $2.1 \%$ & $2.5 \%$ & $2.3 \%$ \\
\hline & & $\%$ of Total & $1.1 \%$ & $1.1 \%$ & $2.3 \%$ \\
\hline & Partial & Count & 17 & 10 & 27 \\
\hline
\end{tabular}


ADHERENCE TO INSTRUCTIONAL PRACTICE GUIDELINES 184

\begin{tabular}{|c|c|c|c|c|c|}
\hline & & Expected Count & 14.7 & 12.3 & 27.0 \\
\hline & & $\%$ within Curriculum & $63.0 \%$ & $37.0 \%$ & $100.0 \%$ \\
\hline & & $\%$ within Affiliation & $35.4 \%$ & $25.0 \%$ & $30.7 \%$ \\
\hline & & $\%$ of Total & $19.3 \%$ & $11.4 \%$ & $30.7 \%$ \\
\hline & Fully & Count & 30 & 29 & 59 \\
\hline & & Expected Count & 32.2 & 26.8 & 59.0 \\
\hline & & $\%$ within Curriculum & $50.8 \%$ & $49.2 \%$ & $100.0 \%$ \\
\hline & & $\%$ within Affiliation & $62.5 \%$ & $72.5 \%$ & $67.0 \%$ \\
\hline & & $\%$ of Total & $34.1 \%$ & $33.0 \%$ & $67.0 \%$ \\
\hline Total & & Count & 48 & 40 & 88 \\
\hline & & Expected Count & 48.0 & 40.0 & 88.0 \\
\hline & & $\%$ within Curriculum & $54.5 \%$ & $45.5 \%$ & $100.0 \%$ \\
\hline & & $\%$ within Affiliation & $100.0 \%$ & $100.0 \%$ & $100.0 \%$ \\
\hline & & $\%$ of Total & $54.5 \%$ & $45.5 \%$ & $100.0 \%$ \\
\hline
\end{tabular}

\section{Chi-Square Tests}

\begin{tabular}{|l|r|r|r|}
\hline & \multicolumn{1}{|c|}{ Value } & df & \multicolumn{1}{c|}{$\begin{array}{c}\text { Asymp. Sig. (2- } \\
\text { sided) }\end{array}$} \\
\hline Pearson Chi-Square & $1.114^{\mathrm{a}}$ & 2 & .573 \\
Likelihood Ratio & 1.124 & 2 & .570 \\
Linear-by-Linear Association & .724 & 1 & .395 \\
N of Valid Cases & 88 & & \\
\hline
\end{tabular}

a. 2 cells $(33.3 \%)$ have expected count less than 5 . The minimum expected count is .91 .

Directional Measures

\begin{tabular}{|c|c|c|c|c|c|c|}
\hline & & & Value & $\begin{array}{c}\text { Asymp. Std. } \\
\text { Error }^{\mathrm{a}}\end{array}$ & $\begin{array}{c}\text { Approx. } \\
\text { T }\end{array}$ & $\begin{array}{c}\text { Approx. } \\
\text { Sig. }\end{array}$ \\
\hline Nominal by & Lambda & Symmetric & .000 & .000 & D &. \\
\hline Nominal & & Curriculum & .000 & .000 & b & b \\
\hline
\end{tabular}


ADHERENCE TO INSTRUCTIONAL PRACTICE GUIDELINES 185

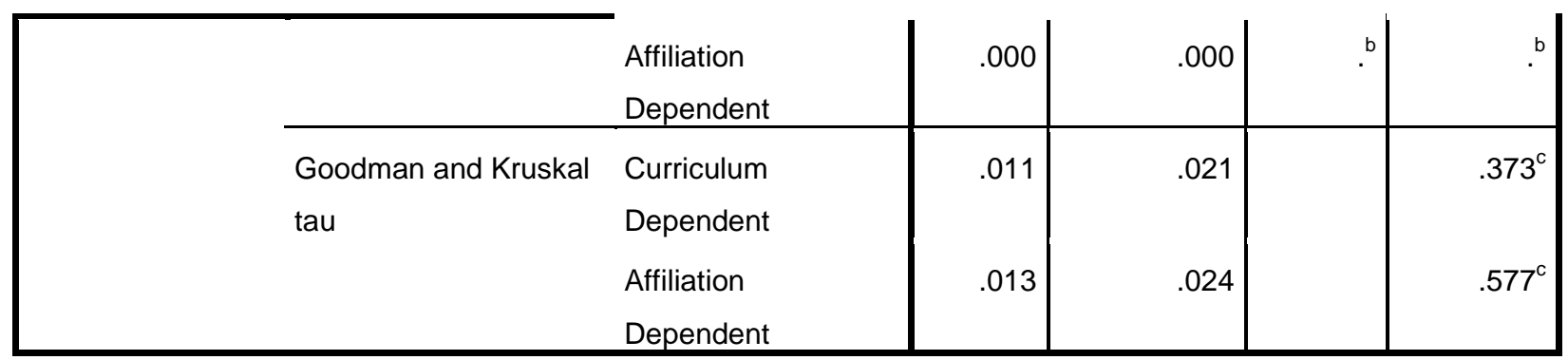

a. Not assuming the null hypothesis.

b. Cannot be computed because the asymptotic standard error equals zero.

c. Based on chi-square approximation

\section{Symmetric Measures}

\begin{tabular}{|ll|r|r|}
\hline & & \multicolumn{1}{|c|}{ Value } & Approx. Sig. \\
\hline Nominal by Nominal & Phi & .112 & .573 \\
& Cramer's V & .112 & .573 \\
& Contingency Coefficient & .112 & .573 \\
N of Valid Cases & & 88 & \\
\hline
\end{tabular}

\section{Curriculum * EnrollmentCondense}

\begin{tabular}{|c|c|c|c|c|c|c|}
\hline \multicolumn{7}{|c|}{ Crosstab } \\
\hline & & & \multicolumn{3}{|c|}{ EnrollmentCondense } & \multirow[b]{2}{*}{ Total } \\
\hline & & & $\begin{array}{c}\text { Small (500- } \\
2500) \\
\end{array}$ & $\begin{array}{c}\text { Medium } \\
(2501-10000)\end{array}$ & $\begin{array}{c}\text { Large } \\
(>10,000)\end{array}$ & \\
\hline \multirow[t]{8}{*}{ Curriculum } & Not at All & Count & 1 & 0 & 1 & 2 \\
\hline & & Expected Count & .8 & .6 & 6 & 2.0 \\
\hline & & $\%$ within Curriculum & $50.0 \%$ & $.0 \%$ & $50.0 \%$ & $100.0 \%$ \\
\hline & & $\%$ within & $2.7 \%$ & $.0 \%$ & $4.0 \%$ & $2.3 \%$ \\
\hline & & EnrollmentCondense & & & & \\
\hline & & $\%$ of Total & $1.1 \%$ & $.0 \%$ & $1.1 \%$ & $2.3 \%$ \\
\hline & Partial & Count & 11 & 5 & 11 & 27 \\
\hline & & Expected Count & 11.4 & 8.0 & 7.7 & 27.0 \\
\hline
\end{tabular}


ADHERENCE TO INSTRUCTIONAL PRACTICE GUIDELINES 186

\begin{tabular}{|c|c|c|c|c|c|c|}
\hline & & $\begin{array}{l}\% \text { within Curriculum } \\
\% \text { within } \\
\text { EnrollmentCondense } \\
\% \text { of Total }\end{array}$ & $\begin{array}{r}40.7 \% \\
29.7 \% \\
12.5 \% \\
\end{array}$ & $\begin{array}{r}18.5 \% \\
19.2 \% \\
5.7 \% \\
\end{array}$ & $\begin{array}{r}40.7 \% \\
44.0 \% \\
12.5 \% \\
\end{array}$ & $\begin{array}{r}100.0 \% \\
30.7 \% \\
30.7 \% \\
\end{array}$ \\
\hline & Fully & $\begin{array}{l}\text { Count } \\
\text { Expected Count } \\
\% \text { within Curriculum } \\
\% \text { within } \\
\text { EnrollmentCondense } \\
\% \text { of Total }\end{array}$ & $\begin{array}{r}25 \\
24.8 \\
42.4 \% \\
67.6 \% \\
28.4 \%\end{array}$ & $\begin{array}{r}21 \\
17.4 \\
35.6 \% \\
80.8 \% \\
23.9 \%\end{array}$ & $\begin{array}{r}13 \\
16.8 \\
22.0 \% \\
52.0 \% \\
14.8 \% \\
\end{array}$ & $\begin{array}{r}59 \\
59.0 \\
100.0 \% \\
67.0 \% \\
67.0 \%\end{array}$ \\
\hline Total & & $\begin{array}{l}\text { Count } \\
\text { Expected Count } \\
\% \text { within Curriculum } \\
\% \text { within } \\
\text { EnrollmentCondense } \\
\% \text { of Total }\end{array}$ & $\begin{array}{r}37 \\
37.0 \\
42.0 \% \\
100.0 \% \\
42.0 \%\end{array}$ & $\begin{array}{r}26 \\
26.0 \\
29.5 \% \\
100.0 \% \\
29.5 \%\end{array}$ & $\begin{array}{r}25 \\
25.0 \\
28.4 \% \\
100.0 \% \\
28.4 \%\end{array}$ & $\begin{array}{r}88 \\
88.0 \\
100.0 \% \\
100.0 \% \\
100.0 \%\end{array}$ \\
\hline
\end{tabular}

Chi-Square Tests

\begin{tabular}{|c|c|c|c|}
\hline & Value & df & $\begin{array}{c}\text { Asymp. Sig. (2- } \\
\text { sided) }\end{array}$ \\
\hline Pearson Chi-Square & $5.093^{\mathrm{a}}$ & 4 & .278 \\
\hline Likelihood Ratio & 5.646 & 4 & .227 \\
\hline Linear-by-Linear Association & 1.070 & 1 & .301 \\
\hline $\mathrm{N}$ of Valid Cases & 88 & & \\
\hline
\end{tabular}

a. 3 cells $(33.3 \%)$ have expected count less than 5 . The minimum expected count is .57 .

Directional Measures

\begin{tabular}{|c|c|c|c|c|c|}
\hline & & Value & $\begin{array}{c}\text { Asymp. Std. } \\
\text { Error }^{a}\end{array}$ & Approx. T & $\begin{array}{c}\text { Approx. } \\
\text { Sig. }\end{array}$ \\
\hline Nominal by Nominal Lambda & Symmetric & .000 & .000 &.$^{b}$ & \\
\hline & Curriculum Dependent & .000 & .000 &. & b \\
\hline
\end{tabular}


ADHERENCE TO INSTRUCTIONAL PRACTICE GUIDELINES 187

\begin{tabular}{|ll|r|r|r|}
\hline & $\begin{array}{l}\text { EnrollmentCondense } \\
\text { Dependent }\end{array}$ & .000 & .000 &.$^{\mathrm{b}}$ \\
\hline $\begin{array}{lll}\text { Goodman and Kruskal } \\
\text { tau }\end{array}$ & $\begin{array}{l}\text { Curriculum Dependent } \\
\text { EnrollmentCondense } \\
\text { Dependent }\end{array}$ & .047 & .026 & $.088^{\mathrm{c}}$ \\
\hline
\end{tabular}

a. Not assuming the null hypothesis.

b. Cannot be computed because the asymptotic standard error equals zero.

c. Based on chi-square approximation

Symmetric Measures

\begin{tabular}{|ll|r|r|}
\hline & & Value & Approx. Sig. \\
\hline Nominal by Nominal & Phi & .241 & .278 \\
& Cramer's V & .170 & .278 \\
& Contingency Coefficient & .234 & .278 \\
N of Valid Cases & & 88 & \\
\hline
\end{tabular}




\section{Appendix K: Current CV}

\section{Drue T. Stapleton, M.Ed, ATC, CSCS}

123 Sturm Street

Clarksburg, WV 26301

email: drue.stapleton@mail.wvu.edu
Home: (304) 624-5669

Work: (304) 293-0866

\section{Education}

Doctor of Philosophy: Kinesiology

Anticipated Completion Date

West Virginia University Morgantown, WV

Summer 2012

Dissertation: Adherence to Appropriate Instructional Practice

Guidelines in American College and University Physical Activity Programs

(Sean M. Bulger, EdD, Chair)

Master of Education: Post-Secondary Education

Degree Conferred

Salisbury University, Salisbury, MD

May 2004

Research Project: Pedagogical Training of CAAHEP Accredited Undergraduate

Athletic Training Educators

Bachelor of Science: Athletic Training and Physical Education

State University of New York, College at Cortland

Degree Conferred

December, 2001

Associate of Arts: Physical Education Studies

Hudson Valley Community College

Degree Conferred

May, 1999

\section{Professional Certifications}

National Athletic Trainers' Association Board of Certification Certified Athletic Trainer (NATABOC-ATC); certification \# 100202017

National Strength and Conditioning Association Certified Strength and Conditioning Specialist (NSCA-CSCS); certification \# 200216880

\section{Academic Appointments}

Date

2011 - Present

2009 - Present

2009 - Present

2007-2009

2008-2009
Institution

Pierpont Community and Technical College

West Virginia University
Adjunct Instructor

\section{$\underline{\text { Position/Title }}$}

Athletic Training Education Graduate

Teaching Assistant; Invited Guest Lecturer, Doctoral Candidate

Adjunct Instructor

Clinical Coordinator of Athletic Training Education

Assistant Professor, Exercise 


$\begin{array}{ccl}\text { 2006-2008 } & \text { West Virginia Wesleyan College } & \begin{array}{l}\text { Instructor, Exercise Science/Athletic } \\ \text { Training }\end{array} \\ \text { 2005-2006 } & \text { West Virginia Wesleyan College } & \begin{array}{l}\text { Visiting Instructor, Exercise } \\ \text { Science/Athletic Training }\end{array} \\ \text { 2002-2004 } & \text { Salisbury University } & \text { Graduate Assistant Athletic Trainer }\end{array}$

\section{Research Interests}

- Negative health outcomes associated with metabolic diseases (obesity, diabetes)

- Interventional strategies to promote physical activity (children, adolescents, college students, adults, elderly)

- Program evaluation

- Professional development and mentoring of undergraduate and graduate students

\section{Honors/Awards}

- College of Physical Activity and Sport Sciences Graduate Student Travel Award 2012

- Patricia K. Fehl Graduate Student Scholarship - 2011-2012

\section{Teaching Activities}

Pierpont Community and Technical College (2011- Present)

Primary Instructor

- HLCA 1170 (3 credits): Anatomy and Physiology; 25 undergraduate students

- HLCA 1171 (1 credit): Anatomy and Physiology Lab; 25 undergraduate students

West Virginia University (2009 - Present)

Primary Instructor

- ATTR 101 (1 credit): Prospective Athletic Training; 117-130 undergraduate students

- ATTR 121 (3 credits): Sports Injury Control and Management; 50 non-athletic training undergraduate students

- ATTR 122 (1 credit): Sports Injury Control and Management Lab; 40 undergraduate Pre-Athletic Training majors

\section{Team Instructor}

- Medical Student III Orthopedic Workshop; approximately 50 medical students

\section{Lab Assistant}

- ATTR 218 (1 credit): Gross Anatomy (cadaver); 13-15 athletic training students

Invited Lecturer

- ATTR 219 Gross Anatomy; 200 undergraduate students

- ATTR 426 Medical Aspects of Athletic Training; 17 undergraduate athletic training students

- ATTR 625 Science and Theory of Rehabilitation: 15 graduate students

- PET 167 Introduction to Physical Education; 100 undergraduate students

\section{West Virginia Wesleyan College (2005-Present)}

\section{Primary Instructor}

- EXSC 360/560 (3 credits): Foundations of Strength and Conditioning; 30 undergraduate students, 5 graduate students. 
- PHED 130 (3 credits): Personal and Community Health; Designed and implemented online course; 30 undergraduate students traditional, 15 undergraduate students online

- PHED 240 (3 credits): Fundamentals of Human Nutrition; Designed and implemented online course; 50 undergraduate students traditional format, 10 undergraduate students online

- PHED 140 (2 credits): First Aid and Safety; 30 undergraduate students

- EXSC 155 (1 credit): Introduction to Athletic Training; 60 undergraduate students

- EXSC 160 (3 credits): Athletic Training I; 15 undergraduate students

- EXSC 163(1 credit): Athletic Training Taping Laboratory; 15 undergraduate students

- EXSC 213 (4 credits): Clinical Techniques of Athletic Training I; 12 undergraduate students

\section{Team Instructor}

- PHED 150 (4 credits): Physical Education Majors I; 20 undergraduate students; taught Health Related Physical Fitness section

\section{Salisbury University (2002-2004)}

- Guest lecturer in undergraduate athletic training education classes

\section{Clinical Experience}

2010- Present Healthworks Rehabilitation and Fitness Morgantown, $W V$

2009-Present West Virginia University Morgantown, $W V$

$2005-2009$

West Virginia Wesleyan College Buckhannon, $W V$

$2004-2005 \quad$ State University of New York College at New Paltz New Paltz, NY

$2002-2004$

2002

Salisbury University Salisbury, $M D$
Columbia Physical Therapy, PC East Greenbush, NY
- Outreach athletic trainer: JamFest, AAU basketball tournaments

- Approved Clinical Instructor,

- Coordinator of Prospective Athletic Training Student (PATS) program,

- Visiting Team Liaison Athletic Trainer: football

- Approved Clinical Instructor

- Head Football athletic trainer

- Men's \& Women's Golf athletic trainer

- Strength and Conditioning Coordinator: Women's Soccer, Football

- NCAA drug testing site coordinator

- Approved Clinical Instructor (Marist College Athletic Training Education program)

- Assistant athletic trainer (15 Varsity sports)

- Graduate Assistant Athletic Trainer: football, track and field, off-season rehabilitation coordinator

- Approved Clinical Instructor

- Head Athletic Trainer for three area high schools

- Assistant Athletic Trainer and Strength and Conditioning Coach for one area high school 


\section{Peer Reviewed Publications}

Stapleton, D. \& Bulger, S.M. (in preparation). Higher Education Physical Activity Programs: An Ecological Perspective. Quest.

Stapleton, D. \& Hawkins, A. (in preparation). Single Case Research Design in Athletic Training. Athletic Training Education Journal.

\section{Book Chapters}

Stapleton, D., Stilger, V.G., \& Koester, M.C. (2011). Safety issues in strength and conditioning. In Koester, M.C (Ed), National Federation of State High School Associations Sports Medicine Handbook, $4^{\text {th }}$ Ed. p.59-61. Indianapolis, IN: National Federation of High Schools.

Stapleton, D. \& Thomas, C. (2009) Introduction, Section 6. Research on Physical Education Teacher Education. In Housner, L.D, Metzler, M.M., Schempp, P. G. and Templin, T. (Eds.) Historic Traditions and Future Directions of Research on Teaching and Teacher Edu cation in Physical Education. pp. xx-xxii. Morgantown, WV: Fitness Information Technology.

DiGiacinto, K. \& Stapleton, D. (2009) Introduction, Section 4. Impediments and Challenges. In Housner, L.D, Metzler, M.M., Schempp, P. G. and Templin, T. (Eds.) Historic Traditions and Future Directions of Research on Teaching and Teacher Education in Physical Education. pp. xvi-xviii. Morgantown, WV: Fitness Information Technology.

\section{Abstracts and Platform Presentations}

Stapleton, D.(2011). University Basic Instruction Programs: Past, Present, Future? Presented at WVAHPERD Conference Flatwoods, WV.

Stapleton, D. (2011). Single Case Design in Athletic Training. Presented at WVAHPERD Conference, Flatwoods, WV.

Stapleton, D. \& Potter, B. (2008). Use of video analysis software for upper extremity biomechanical analysis, WV Athletic Trainers' Association Annual Meeting, Buckhannon, WV.

Stapleton, D. (2008). Bridging the Gap: Student to Certified. Presented at MAATA Annual Meeting, Student Symposium.

Stapleton, D. \& Sibold, J. (2007). Athletic Pubalgia and Adductor Tendon Avulsion Repair in a Collegiate Football Player. Poster Presentation, EATA Annual Meeting and Symposium.

Stapleton, D. (2004). The Instructional Methods of CAAHEP-Accredited Undergraduate Athletic Training Educators. Unpublished Master's research project.

\section{Invited Research Symposia}

Stapleton, D. (2012). Single case research design in athletic training; an alternative strategy for evidence based practice. SUNY Cortland Sports Medicine Symposium, Cortland, NY.

\section{Departmental Service}

- 2012: developed Athletic Training Education Graduate Assistant Handbook

- 2009 - present: WVU Student academic advisor 
- 2009 - present: WVU Athletic Training webpage coordinator

- 2009 - present: maintained Prospective Athletic Training Student Handbook

- 2009 - present: recruiting appointments with prospective students and families

- 2006-2009: WVWC Student academic advisor

- 2006 - 2009: WVWC: recruiting appointments with prospective students and families

\section{Institutional Service}

- 2009 - present: WVU new student orientation advisor

- 2008-2009: Chair; WVWC Institutional Research Review Board

- 2007-2009: Faculty advisor; WVWC Ski Club

- 2006 - 2008: member; WVWC Institutional Research Review Board

- 2006: Chairperson, WVWC Co-Curricular Think Tank

- 2006: Member, WVWC e-Learning Think Tank

\section{State/District/National Service}

- 2012 - present: WV Athletic Trainers' Association (WVATA) President

- 2008 - present: WV representative, Mid-Atlantic Athletic Trainers' Association (MAATA) Scholarship committee

- 2007 - present: WV representative, MAATA Public Relations committee

- 2007-present: Chair, WVATA public relations committee

- 2011, 2012: WVATA Annual Meeting Program Co-Coordinator

- 2010-2012: WVATA President Elect

- 2008-2010: WVATA Secretary

- 2008: WVATA Annual Meeting Program Coordinator

\section{Memberships}

- 2011- present: member, National Association of Kinesiology and Physical Education in Higher Education (NAKPEHE)

- 2010 - present: member, WV Alliance of Health, Physical Education, Recreation and Dance (WVAHPERD)

- 2010 - present: member, American Alliance of Health, Physical Education, Recreation and Dance (AAHPERD)

- 2005- present: member, WVATA

- 2002- present: NATABOC certified examiner

- 2002 - present: member, National Athletic Trainers'Association (NATA) District III

\section{Meetings Attended}

- 2012: MAATA Annual Meeting; Greenville, SC.

- 2012: AAHPERD Annual Meeting; Boston, MA.

- 2012: WVATA Annual Meeting, Morgantown, WV

- 2011: WVATA Annual Meeting, Morgantown, WV.

- 2011: WVAHPERD Annual Meeting, Flatwoods, WV.

- 2010: National Athletic Trainers' Association (NATA) Annual Meeting, Philadelphia, PA.

- 2009: WVATA Annual Meeting: Charleston, WV 
- 2007: WVATA Annual Meeting, Charleston, WV.

- 2007: MAATA Annual Meeting and Symposium, Virginia Beach, VA.

- 2008: WVATA Annual Meeting, Buckhannon, WV.

- 2008: MAATA Annual Meeting, Virginia Beach, VA.

- 2006: Eastern Athletic Trainers' Association (EATA) Annual Meeting, Boston, MA.

- 2006: NATA Annual Meeting, Atlanta, GA.

- 2005: NATA Annual Meeting, Indianapolis, IN.

- 2004: MAATA Annual Meeting and Symposium, Virginia Beach, VA.

- 2004: NATA Annual Meeting, Baltimore, MD.

- 2003: EATA Annual Meeting, Boston, MA.

- 2003: MAATA Annual Meeting and Symposium, Virginia Beach, VA. 